\title{
Direito civil, de família e constituicional e gênero, sexualidades e direito
}

Ana Gascón Marcén, Aurelio Barrio Gallardo, Eudes Vitor Bezerra, Javier Martínez Calvo, Silvana Beline Tavares

(coords.) 



\section{COMITÉ CIENTÍFICO}

\section{SERIE LEFIS}

\section{Coordinación}

Prof. Fernando Galindo Ayuda. Universidad de Zaragoza

Profa. María Pilar Lasala Calleja. Universidad de Zaragoza

Consejo asesor

Prof. Javier García Marco. Universidad de Zaragoza

Prof. Alejando González-Varas Ibáñez. Universidad de Zaragoza

Prof. Philip Leith. Universidad Queen's de Belfast

Prof. Emérito Abdul Paliwala. Universidad de Warwick

Prof. Aires Rover. Universidad Federal de Santa Catarina

Prof. Erich Schweighofer. Universidad de Viena

Prof. Ahti Saarenpää. Universidad de Rovaniemi 
DIREITO CIVIL,

DE FAMÍLIA E CONSTITUICIONAL

E GÊNERO, SEXUALIDADES E DIREITO 



\title{
DIREITO CIVIL, DE FAMÍLIA E CONSTITUICIONAL E GENNERO, SEXUALIDADES E DIREITO
}

\author{
Ana Gascón Marcén, Aurelio Barrio Gallardo, \\ Eudes Vitor Bezerra, Javier Martínez Calvo, \\ Silvana Beline Tavares \\ (coords.)
}
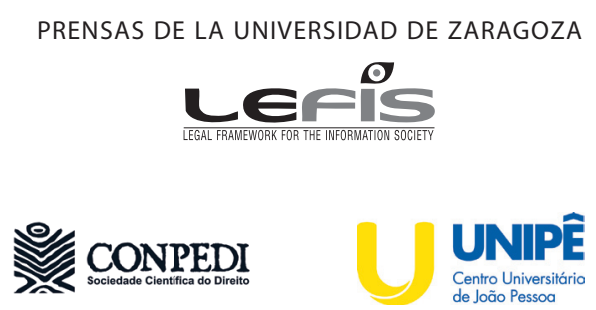
DIREITO civil, de família e constituicional e Gênero, sexualidades e Direito [Recurso electrónico] / Ana Gascón Marcén... [et al.] (coords.). - Zaragoza : Prensas de la Universidad de Zaragoza, 2019

324 p. ; $22 \mathrm{~cm}$. - (LEFIS series ; 21)

ISBN 978-84-17633-55-4

1. Informática-Derecho-Brasil. 2. Internet en la administración pública. 3. Derecho civil-Brasil. 4. Derecho de familia-Brasil. 5. Derecho constitucional-Brasil. 6. Discriminación sexual-Derecho-Brasil

GASCÓN MARCÉN, Ana

34(81):004

$004.738 .5: 35$

$004.738: 34(81)$

$004.738: 347.65 / .67(81)$

004.738:342.4(81)

$004.738: 342.72 / .73-055.2(81)$

Cualquier forma de reproducción, distribución, comunicación pública o transformación de esta obra solo puede ser realizada con la autorización de sus titulares, salvo excepción prevista por la ley. Diríjase a CEDRO (Centro Español de Derechos Reprográficos, www.cedro.org) si necesita fotocopiar o escanear algún fragmento de esta obra.

(C) LEFIS

(C) CONPEDI, Conselho Nacional de Pesquisa e Pós-Graduação em Direito Brasil.

(C) De la presente edición, Prensas de la Universidad de Zaragoza (Vicerrectorado de Cultura y Proyección Social)

$1 .^{a}$ edición, 2019

El Centro Universitário de João Pessoa - PB - UNIPÊ ha subvencionado parcialmente la edición de este libro.

Prensas de la Universidad de Zaragoza. Edificio de Ciencias Geológicas, c/ Pedro Cerbuna, 12. 50009 Zaragoza, España. Tel.: 976761 330. Fax: 976761063

puz@unizar.es http://puz.unizar.es

https://www.conpedi.org.br/

Esta editorial es miembro de la UNE, lo que garantiza la difusión y comercialización de sus publicaciones a nivel nacional e internacional. 


\section{SUMÁRIO}

\section{DIREITO CIVIL, DE FAMÍLIA E CONSTITUICIONAL}

APRESENTAÇÃO......

Eudes Vitor Bezerra, Javier Martínez Calvo, Aurelio Barrio Gallardo.

A CONSTITUCIONALIZAÇÃO DO DIREITO CIVIL E O DIREITO À PRIVACIDADE: ANÁLISE ACERCA DA SUBMISSÃO OBRIGATÓRIA DE IDENTIFICAÇÃO DE PERFIL GENÉTICO DE CONDENADOS

Bricio Luis da Anunciação Melo, Clara Angélica Gonçalves Cavalcanti Dias.

A SEGURANÇA JURÍDICA DA USUCAPIÃO EXTRAJUDICIAL EM FACE DO PROCEDIMENTO JUDICIAL

Dênio Guilherme Dos Reis.

APLICABILIDADE DA TUTELA ANTECIPADA OU CAUTELAR (LIMINARES) NO DIREITO DE FAMÍLIA: INSTRUMENTOS PARA A SOLUÇÃO DOS CONFLITOS FAMILIARES

Eudes Vitor Bezerra, Marcelo Negri Soares.

AUTONOMIA PRIVADA E A (IM)POSSIBILIDADE DE RENÚNCIA A DIREITO FUNDAMENTAL: EUTANÁSIA E SUICIDIO ASSISTIDO.

Edilene Lobo, Suzana Oliveira Marques Brêtas.

BULLYING E DANO MORAL: A PROBLEMÁTICA DA RESPONSABILIDADE CIVIL DA ESCOLA PARTICULAR.

Fabrício Veiga Costa, Denise Maria Soares.

ESTATUTO DA PESSOA COM DEFICIÊNCIA E AS NOVAS REGRAS DA INCAPACIDADE CIVIL 115

Ariolino Neres Sousa Junior.

O CONCEITO DE DIREITO DE AUTODETERMINAÇÃO INFORMACIONAL E A ANÁLISE DO DANO: REFLEXÕES PARA QUE A RESPONSABILIDADE CIVIL ENCONTRE SUA MEDIDA E EXTENSÃO NA SOCIEDADE CONTEMPORÂNEA.....136 Karin Anneliese Pupp.

O CONVALESCIMENTO DA POSSE PRECÁRIA NAS MODALIDADES EXTRAORDINÁRIAS DE USUCAPIÃO.

Karina Pinheiro de Castro.

PERSPECTIVA DE CONVIVÊNCIA EM REDE FAMILIAR E A ORIGEM GENÉTICA NA RELAÇÃO SOCIOAFETIVA. 180

André Vinícius Guimarães de Carvalho, Paulo Joviniano Alvares dos Prazeres.

VARIAÇÕES SOBRE O MESMO TEMA: O CONTRATO EM CONTEXTO POLÍTICO, SOCIAL E ECONÔMICO. 200

Laís Machado Lucas. 


\section{GÊNERO, SEXUALIDADES E DIREITO}

APRESENTAÇÃO

Silvana Beline Tavares, Ana Gascón Marcén.

A AUTONOMIA E A DIGNIDADE DA PESSOA HUMANA SOB A ÓTICA DA SITUAÇ̃̃O DOS TRANSEXUAIS

Letícia da Silva Almeida, Lucas Fortini Bandeira.

A CONDIÇÃO DE AGENTE DAS MULHERES COMO PEÇA FUNDANTE DO DESENVOLVIMENTO

Paula Isabel Nobrega Introine Silva, Hertha Urquiza Baracho.

A IMPLEMENTAÇÃO DO DIREITO FUNDAMENTAL À IDENTIDADE DE GÊNERO POR MEIO DE POLÍTICAS PÚBLICAS DE INCLUSÃO DOS TRANSGÊNEROS NO

BRASIL

Fabrício Veiga Costa, Denise Maria Soares.

REFLEXÕES JURÍDICAS PERSISTENTES APÓS O RECONHECIMENTO PELO STF DO DIREITO DAS PESSOAS TRANSGÊNERO A ADEQUAÇAO DO NOME E GÊNERO SEM A REALIZACAO DE CIRURGIAS.

Tereza Rodrigues Vieira, Valéria Silva Galdino Cardin.

RESPONSABILIDADE CIVIL DOS MÉDICOS NOS CASOS DE CIRURGIA DE REDESIGNAÇÃO DE SEXO DOS TRANSEXUAIS 303

Cintia Rosa Pereira de Lima, Emanuele Pezati Franco De Moraes. 


\section{DIREITO CIVIL, DE FAMÍLIA E CONSTITUICIONAL ${ }^{1}$}

\section{APRESENTAÇÃO}

$-\mathrm{I}-$

La Constitución tiene atribuido un poder revolucionario en tanto que puede crear conceptos inéditos que después deben ser asumidos por el legislador ordinario en virtud del principio de jerarquía normativa. Tanto los dictados del TC como, ante todo, la reinterpretación de los derechos fundamentales efectuada de la mano de ciertos tribunales supranacionales han ido espoleando los antiguos Códigos civiles europeos. Las normas decimonónicas deben abandonar los planteamientos que un su día inspiraron su redacción para comenzar progresivamente a adaptarse a este nuevo orden jurídico y a los problemas sociales del presente. El epicentro del Derecho civil occidental, como conjunto disciplinado de derechos subjetivos, es el propio individuo; el libre desarrollo de la personalidad y la dignidad humana son los pilares sobre los que debe erigirse la totalidad del sistema.

En España esta transición no está siendo fácil; en unas ocasiones, el camino elegido ha llevado al legislador a abusar de la técnica del parcheado; en otras, se ha cincelado el Código a golpe de sucesivas reformas conforme venían impuestas por la doctrina constitucional, quizá sin consideración suficiente a la armonía que ha de presidir la sistemática de un ordenamiento jurídico en su conjunto. Buena parte de este esfuerzo de modernización ya ha sido realizado por algunos países de América Latina. Entre los más vanguardistas descuella con voz propia Brasil cuyo nuevo Código civil (2002) ha sabido aclimatarse al signo de los tiempos y ofrecer solución a la mayoría de los interrogantes actuales. Da muestra sobrada de ello las artículos expuestos durante este encuentro de internacionalización que nuestra Facultad ha tenido el orgullo de poder acoger. Sin duda el análisis comparativo de ambos sistemas y el intercambio de experiencias ha resultado tan provechoso como enriquecedor para los juristas de ambas latitudes.

\footnotetext{
${ }^{1}$ Nota Técnica: Os artigos que não constam neste livro foram selecionados para publicação na Plataforma Index Law Journals, - http://indexlaw.org/index.php/conpedireview/index.
} 
Fabrício Veiga Costa y Denise Maria Soares llevan a cabo una investigación acerca del fenómeno del bullying en la escuela y la posibilidad de que la propia institución de enseñanza responda civilmente por los daños morales causados a la víctima como consecuencia de su conducta omisiva. Bricio Luis Da Anunciacao Melo y Clara Angélica Gonçalves Cavalcanti Dias presentan un estudio sobre el derecho a la protección de la privacidad de condenados y el modo en el que éste puede verse afectado por la obligación que establece la Ley 12654/2012 de identificación del perfil genético de los condenados.

Tras un estudio exhaustivo de la doctrina especializada, Eudes Vitor Bezerra y Marcelo Negri Soares con apoyo en la amenaza del perjurio, apuestan por la necesidad de dotar de celeridad a la resolución de los conflictos familiares en las fases iniciales del proceso, para descongestionar la sobrecargada administración de justicia brasileña. Ariolino Neres Sousa Junior lleva a cabo un estudio acerca de las nuevas reglas de la incapacidad civil establecidas por el Estatuto de la Persona con Discapacidad aprobado a través de la Ley 13146/2015.

El trabajo presentado por Karina Pinheiro de Castro ofrece una visión crítica de la disposición del art. 1208 del CC brasileño sustentada en un abundante aparato crítico. Con apoyo en el principio constitucional de la función social la autora explora la posibilidad de que el precarista pueda llegar a recuperar la posesión e incluso usucapir la propiedad del bien cuya tenencia material ostenta. Dênio Guilherme Dos Reis efectúa una comparación entre la posesión extrajudicial adversa en la antigua Ley rituaria de 1973 y las innovaciones incorporadas por el Código procesal civil para ofrecer un sugerente panorama sobre el instituto a la vista de las disposiciones administrativas registrales en vigor.

Tratar de desentrañar el concepto de autodeterminación informativa al efecto de poder precisar qué daños resultan indemnizables es el objetivo que se propone Karin Anneliese Pupp para concluir que la noción Selbstbestimmung no se encuentra todavía suficientemente asentada y requiere de una mayor profundización doctrinal. Lais Machado Lucas defiende un trabajo cuya tesis principal es que las interferencias generadas por los grandes agentes económicos han llevado a que el concepto de contrato haya experimentado una verdadera transformación. Tras esta mutación el negocio jurídico por antonomasia ha dejado de ser reflejo de la voluntad de las partes para expresar intereses diversos de aquellos que son fruto de la autonomía privada. 
Paulo J. Alvares dos Prazeres y André V. Guimarães de Carvalho contraponen el anonimato de los donantes en la fecundación in vitro al derecho a conocer los orígenes biológicos y la identidad genética. El resultado es un vínculo socio-afectivo con todos los implicados en el proceso reproductivo desde un concepto más amplio de familia. Edilene Lôbo y Suzana Oliveira efectúan un análisis del derecho a una muerte sin sufrimiento a través de la eutanasia y el suicidio asistido cuestionando que el Estado deba inmiscuirse en el ejercicio de tal libertad; la autonomía privada debe poder realizarse en todas las fases de la vida, incluida la terminal, a través de actos de dignificación de la persona como son las voluntades anticipadas.

-III-

Tras la atenta consulta de los trabajos que ahora se presentan al lector, se puede concluir con carácter general que el Derecho civil y sus instituciones sempiternas han iniciado su andadura en el S. XXI teniendo que hacer frente a un sinfín de nuevos retos dentro de una realidad social siempre cambiante. El respeto a la dignidad humana y a los derechos fundamentales han llevado a reinterpretar figuras clásicas de nuestra disciplina (matrimonio, filiación, incapacitación...); la visión de principios constitucionales ya asentados (investigación de la paternidad, tutela judicial efectiva, función social de la propiedad, libre desarrollo de la personalidad...) con nuevos ojos ha supuesto una evolución constante de esta materia a través de reformas parciales en nuestro país o con la formulación de un Código de nuevo cuño en Brasil.

Lo mismo cabría decir de la celeridad del tráfico económico, la irrupción de las nuevas formas de contratación y el avance imparable de las TIC (certificados digitales, firmas electrónicas, técnicas de reproducción asistida, criogenización, inteligencia artificial...), que han venido para quedarse. Esta rica fenomenología social ofrece retos legales y éticos a los que el jurista debe hacer frente. Tanto en los desafíos presentes como en los que aún están por llegar la labor asumida por la Academia a través de la argumentación resulta vital en este proceso de aclimatación para que el ordenamiento pueda dar una justa respuesta a los problemas de los ciudadanos. Y a ello aspiran con el resultado de sus investigaciones los participantes en esta VIII edición del CONPEDI.

En la Facultad de Derecho de Zaragoza, a 14 de septiembre de 2018 
Coordenadores do GT:

Prof. Dr. Eudes Vitor Bezerra - UNINOVE

Prof. Dr. Javier Martínez Calvo - UNIZAR

Prof. Dr. Aurelio Barrio Gallardo - UNIZAR 


\title{
A CONSTITUCIONALIZAÇÃO DO DIREITO CIVIL E O DIREITO À PRIVACIDADE: ANÁLISE ACERCA DA SUBMISSÃO OBRIGATÓRIA DE IDENTIFICAÇÃO DE PERFIL GENÉTICO DE CONDENADOS
}

\author{
Bricio Luis da Anunciação Melo \\ Universidade Federal de Sergipe
}

Clara Angélica Gonçalves Cavalcanti Dias

Universidade Federal de Sergipe

\section{Resumo}

O Direito Civil passou por grandes transformações. De caráter patrimonialista, sofreu um processo de releitura com o advento da Constituição Federal de 1988, em decorrência da Constitucionalização do Direito. A privacidade, concebida como direito fundamental à autodeterminação informativa, defere ao indivíduo o controle de seus dados pessoais, inclusive os dados genéticos. A lei 12.654/2012 ao prever a submissão obrigatória de pessoas condenadas em crimes hediondos à identificação de perfil genético, mediante a extração de DNA, viola o direito à privacidade, pois transforma pessoas condenadas em indivíduos desprovidos de dignidade, completamente sujeitos ao arbítrio Estatal.

Palavras-chave: Direito Civil Constitucional, Constitucionalização do Direito, Privacidade, Perfil genético, Dignidade da pessoa humana.

\begin{abstract}
Resumen/Résumé
The Civil Law has undergone major transformations. With patrimonial character, underwent a re-reading process with the advent of the Federal Constitution of 1988, as a result of the Constitutionalisation of Law. Privacy, conceived as a fundamental right to informative selfdetermination, gives people the control of his personal data, including genetic data. The law 12.654 / 2012, when it foresees the obligatory submission of convicted persons in heinous crimes to the identification of a genetic profile, through the extraction of DNA, violates the right to privacy, since it transforms condemned persons into individuals deprived of dignity, completely subject to State arbitration.
\end{abstract}


Keywords/Palabras-claves/Mots-clés: Constitutional Civil Law, Constitutionalisation of Law, Privacy, Genetic profile, Dignity of human person.

\section{Introdução}

O Direito Civil passou por grandes transformações no final do século XX no Brasil. De caráter patrimonialista, tendo por base o Código Civil de 1916, sofreu um processo de releitura com o advento da Constituição Federal de 1988. Por meio da Constitucionalização do Direito, os valores e princípios constitucionais passaram a ser irradiados pelo ordenamento jurídico, inclusive no âmbito do direito privado. Velhos institutos tiveram nova roupagem quando lidos através do princípio da dignidade da pessoa humana, fundamento de nossa Carta Magna.

Em decorrência dessa dignidade, ao ser humano hoje são conferidos direitos inerentes à sua natureza, de modo a serem reconhecidos direitos ao homem pela simples razão de sua existência, não se cogitando excludentes em razão de condições peculiares como encarceramento ou cometimento de delitos graves.

Assim, a dignidade da pessoa humana permeou a construção dos direitos humanos, hoje não apenas reconhecidos em âmbito internacional, como no ornamento jurídico pátrio por meio dos direitos fundamentais e da personalidade. Dentre os direitos da personalidade, destaca-se a privacidade, na qual o indivíduo encontra um "espaço indevassável destinado a protegê-lo contra indevidas interferências de terceiros". (BRASIL, STF, 2000)

Entretanto, ao mesmo tempo em que se vislumbra o reconhecimento da privacidade como direito da personalidade, constata-se que há hipóteses de violação grave a esse direito, como se dá no caso de condenados em crimes hediondos. Por meio da Lei 12654/2012 foi prevista a submissão obrigatória de condenados em crimes hediondos à identificação do perfil genético, mediante a extração de DNA. Nesse caso, privilegiou-se a tutela da segurança pública e investigação criminal e deixou-se de lado à proteção à privacidade de condenados ou investigados, tornando-os indivíduos de segunda categoria, desprovidos de direitos da personalidade.

O presente texto tem por escopo demonstrar que a submissão obrigatória à coleta de material genético da pessoa condenada por crime hediondo viola os direitos da personalidade da pessoa do preso, no que tange à sua privacidade. Isso decorre do valor dignidade da pessoa 
humana de nossa Constituição Federal, o qual foi irradiado para o Direito Civil, em uma perspectiva de Constitucionalização do Direito.

Com tal desiderato, far-se-á uma análise da evolução histórica do homem como sujeito de direitos até o reconhecimento da dignidade da pessoa humana como valor em nossa Constituição Federal. Com base na Constitucionalização do Direito, sustentar-se-á que a dignidade é um valor irradiado por todo o ordenamento jurídico, acarretando uma mudança de paradigma no Direito Civil pátrio. Com lastro nesse marco teórico, tratar-se-á do direito à privacidade da pessoa do condenado, que não deve ser excepcionado face o encarceramento ou em nome da segurança pública.

Para o atingimento desse fim, far-se-á amplo uso da técnica de revisão de literatura sobre direito à privacidade, notadamente por ser um trabalho com questionamentos jurídicos. Por outro lado, serão invocados alguns aspectos do método histórico, de modo a localizar acontecimentos cujos desdobramentos auxiliam a compreensão do estado atual do valor conferido ao ser humano.

\section{O indivíduo dotado de dignidade na seara do Direito Privado: a constitucionalização do Direito Civil}

A ideia de que o homem é um ser sujeito de direitos, dotado de dignidade e valor de per si, não surgiu de pronto na história. Forjou-se ao longo da civilização até atingir o atual estágio, em que os direitos fundamentais encontram-se positivados nas Constituições, não apenas como forma de proteção dos mesmos, mas para garantir sua máxima efetividade.

O conceito de personalidade, afeto à seara do Direito Privado, confunde-se, em grande parte, com a noção de dignidade do próprio homem. Afinal, apenas ao homem dotado de uma dignidade imanente, pode ser conferida personalidade. Em Roma, a ideia de personalidade adveio das personae, máscaras mortuárias dos ancestrais. Era dotado de personalidade quem era depositário dessas imagines e do sobrenome dos antepassados: o pater familias (SUPIOT, 2007). Com efeito, nem todos os seres humanos possuíam personalidade, haja vista a possibilidade de serem tratados juridicamente como coisas, o que ocorria com os escravos.

O conceito de dignidade da pessoa humana, que permeia a construção dos direitos humanos, deveu-se, em grande parte, ao Cristianismo. Para os gregos, o homem, muito mais do que portador de uma dignidade imanente à sua natureza, apenas possui valor no serviço ao Estado. Nesse sentido, Antonio Carlos Wolkmer esclarece que se desconsiderava uma noção de direito inato, oriundo da natureza ou dignidade do próprio homem haja vista a estrutura 
sociopolítica da época não conceber direitos individuais ou personalísticos (WOLKMER, 2005, p. 2).

O Cristianismo conferiu impulso relevante para o reconhecimento de que o homem é dotado de uma dignidade imanente, inalienável e que merece proteção especial (MORAES, 2003, p. 112). Ora, se o homem foi criado à imagem e semelhança de Deus e se o Criador enviou seu Filho para redimir a humanidade, o homem passa a ser encarado como possuidor de um valor inestimável. Passam-se a reconhecer ao homem direitos pela simples razão de sua existência.

Essa concepção de direitos inerentes ao homem - direitos humanos - afastou-se de sua origem teológica e, com a Idade Moderna, passou a assumir uma feição realmente antropocêntrica. Esse processo culminou com o reconhecimento de direitos que, por resultarem da natureza humana, preexistem ao próprio Estado, revelando, assim, a característica que confere legitimação ao próprio Estado: uma instituição forjada para garantir os direitos básicos aos cidadãos (MENDES, 2011, p.155).

Nesse processo de reconhecimento e positivação dos Direitos Humanos, imperioso mencionar a Declaração Universal dos Direitos do Homem, de 10 de dezembro de 1948, a qual reconheceu, dentre inúmeros direitos, a intimidade como direito fundamental do ser humano ao declarar, em seu artigo 12 que, “ninguém será sujeito à interferência em sua vida privada, em sua família, em seu lar ou em sua correspondência, nem a ataque à sua honra e reputação. (...).

Esses direitos da pessoa humana, quando acolhidos na ordem interna do estado soberano, convertem-se na categoria de direitos fundamentais - não perdem seu caráter de direitos humanos - e são apreendidos numa Constituição. Dessa forma, a Constituição Federal de 1988, no artigo 5, X, assegura que "são invioláveis a intimidade, a vida privada, a honra e a imagem das pessoas, assegurado o direito a indenização pelo dano material ou moral decorrente de sua violação".

Os direitos fundamentais passaram, então, a serem positivados na Constituição dos Estados modernos como meio de assegurar que os direitos humanos, reconhecidos na ordem internacional, realizassem, de fato, no âmbito de cada Estado, o seu papel de limitação da atuação estatal e promoção dos direitos individuais.

Eis que surge um novo movimento constitucional em que as Constituições passaram a ser consideradas não apenas o centro jurídico-formal dos ordenamentos jurídicos, mas, também, no aspecto material: o neoconstitucionalismo. Esse direito constitucional contemporâneo surge no contexto histórico da redemocratização, com a Constituição Federal 
de 1988, e tem como marco filosófico o pós-positivismo, que é uma tentativa de ir além da legalidade estrita, sem, para esse intento, desprezar o direito positivo. Nele, a interpretação e aplicação do ordenamento jurídico hão de ser inspiradas por uma teoria de justiça, acarretando a formação de uma nova hermenêutica constitucional e o desenvolvimento de uma teoria dos direitos fundamentais edificada sobre o fundamento da dignidade humana. (BARROSO, 2005, p.6)

Como conseqüência desse Direito Constitucional Contemporâneo, confere-se normatividade aos princípios, que passam a ser aplicados diretamente na solução dos conflitos, bem como o que a doutrina chama de Constitucionalização do Direito.

Essa expressão, que é de uso relativamente recente, comporta múltiplos sentidos (BARROSO, 2005). A ela pode se referir, genericamente, um ordenamento cujo centro seja uma Constituição dotada de supremacia. Pode-se mencionar, outrossim, o fato de direitos infraconstitucionais serem alocados na Constituição, que passa a tratar de matérias não eminentemente constitucionais. É o que vemos na Constituição brasileira de 1988 que trata questões de direito civil, penal e administrativo, os quais, em razão disso, assumem status constitucional.

Destarte, a expressão, no sentido aqui empregado, cuida do fenômeno oposto. Constitucionalização do Direito é a irradiação dos valores, princípios e regras constitucionais por todo o sistema jurídico. A Constituição e seus valores passam a modificar o sentido e alcance das normas infraconstitucionais, de modo de a legislação passa ser interpretada por meio da Constituição.

Com efeito, passou-se a compreender que a Constituição não pretende ser axiologicamente neutra, de modo que os direitos fundamentais não seriam apenas garantias individuais, mas também uma ordem objetiva de valores. Tal revolução na maneira de encarar os direitos fundamentais ocorreu no julgamento do Caso Lüth ${ }^{1}$, pelo Tribunal Constitucional Alemão, o qual entendeu pela existência de um sistema de valores, que tem seu ponto central no livre desenvolvimento da personalidade e na dignidade humana no seio da comunidade social, devendo valer como decisão fundamental para todos os ramos do direito (SILVA, Virgílio, 2014, p. 42).

\footnotetext{
${ }^{1}$ Decisão do Tribunal Constitucional Alemão em que se analisou o 826 do Código Civil alemão, decidindo que ele deve funcionar como uma das "portas de entrada dos direitos fundamentais nas relações entre particulares, seja para anular decisões que não tenham levado os direitos fundamentais em consideração, seja para anular relações jurídicas entre particulares que ofendam a ideia de bons costumes, reinterpretada à luz dos direitos fundamentais." (SILVA, Virgílio, 2014, p. 80).
} 
A dignidade da pessoa humana, fundamento da República, e os valores dela decorrentes passaram a ser irradiados, no ordenamento jurídico nacional, em todos os ramos do Direito e, em especial, no Direito Civil. Na Constitucionalização do Direito, a incidência do princípio da dignidade da pessoa humana acarretou uma reanálise dos institutos civis, dentre eles, os direitos da personalidade.

Assim, a "principal manifestação da preeminência normativa da Constituição consiste em que toda a ordem jurídica deve ser lida à luz dela e passada pelo seu crivo" (CANOTILHO, MOREIRA, 1991, p. 45). É o que a doutrina passou a denominar filtragem constitucional, uma vez que a Constituição seria uma lente, por meio da qual, os ramos do direito devem ser lidos e interpretados. Dentre todos, o Direito Civil foi aquele que mais sentiu esse fenômeno ${ }^{2}$.

Nesse particular, cabe salientar que relações jurídicas se dão entre indivíduos. É por meio deles que os diversos contratos são celebrados, como a compra e venda. Sem indivíduos não haveria o casamento, tal qual tutelado no artigo 1.511 do Código Civil. Cabe, ainda, ressaltar que é por meio do falecimento ou ausência de uma pessoa que surge o direito sucessório. Desta feita, é a tutela dos indivíduos a razão maior de ser do Direito Civil.

Um contrassenso ocorreu no Brasil desde a época de Império até a Nova República ${ }^{3}$, pois o patrimônio ocupou, indevidamente, o lugar reservado ao indivíduo como base do Direito Civil brasileiro. Era o tempo de uma sociedade agrária, em que a tutela do patrimônio não cedeu espaço para o surgimento e posterior defesa dos direitos de personalidade. Os direitos que não tinham um cunho patrimonial foram relegados a um segundo plano, apenas surgindo no final do século XX por meio da Constituição Federal de 1988 e do Código Civil de 2002.

O Código Civil de 1916, patrimonialista em sua essência e não consentâneo com a realidade urbana já vivenciada no país, não cuidava dos direitos de personalidade. Tais direitos, por não serem patrimoniais, permaneceram, durante muito tempo renegados em um sistema outrora patrimonialista.

Cabe destacar que nessa época o Código Civil ocupava um lugar de destaque sem igual no ordenamento jurídico pátrio. Isso decorreu da ideia de o Código Civil de Napoleão tutelar, o mais amplamente possível, as relações jurídicas existentes. Assim, o Código Civil foi erigido

\footnotetext{
${ }^{2}$ Foi o que ocorreu quando o Supremo Tribunal Federal, no julgamento conjunto dos RE's 646721 e 878694 , declarou a inconstitucionalidade do artigo 1.790 do Código Civil, que estabelecia diferenças entre a participação do companheiro e do cônjuge na sucessão dos bens. Foi assentado o entendimento de que tal diferenciação violava a dignidade da pessoa humana do companheiro. Assim, o Código Civil deveria ser lido em conformidade à Constituição, especialmente no que tange à igualdade.

${ }^{3}$ Nova República é o período da História brasileira que se segue ao declínio da ditadura militar. É quando foi promulgada a Constituição Federal de 1988.
} 
a um status quo elevadíssimo no ordenamento jurídico, mormente em função da regulação das relações privadas.

Essa situação mudou com a Constitucionalização do Direito Civil. As Constituições passaram a ser não apenas o fundamento jurídico-normativo do sistema, como também se tornaram a base interpretativa das normas inferiores. Ou seja: a interpretação da legislação civilista passou a ser feita por meio da Constituição, devendo haver a adequação das normas privadas aos princípios vigentes adotados na Carta da República. Nesse sentido, colaciono:

(...) a Constituição da República de 1988 instaurou nova ordem jurídica no país, realocou valores, instituiu novos princípios, impondo assim o repensar de todo o ordenamento jurídico. A normativa constitucional, seu conjunto de regras e princípios, passa a incidir diretamente no caso concreto, nas relações intersubjetivas. Desta forma, as categorias e conceitos do direito civil devem ser criticadas e reconstruídas, tendo como norte a consecução do projeto constitucional (TEPEDINO, 2002, p. 2).

Com efeito, a dignidade da pessoa humana, fundamento da República, e os valores dela decorrentes passaram a ser irradiados, no ordenamento jurídico nacional, em todos os ramos do Direito e, em especial, no Direito Civil. No campo privado, a incidência do princípio da dignidade da pessoa humana acarretou uma reanálise dos institutos civis, dentre eles, os direitos da personalidade. Tais direitos ganharam força na escala de repersonalização, na medida em que o patrimônio cedeu espaço à tutela da pessoa no ordenamento jurídico nacional.

Assim, através da repersonalização promovida pela Constituição, a pessoa humana tornou-se a base do Direito Civil, passando o papel de coadjuvante para o patrimônio. Esse processo extinguiu o ideário liberal individualista burguês da Revolução Francesa e pode ser constatado em diversos pontos do novo Direito Civil Constitucional. Citam-se como exemplos o fato de a família hoje ser um local de convivência socioafetiva, o surgimento dos direitos de personalidade e a resolução de conflitos por meio da aplicação direita do princípio da dignidade da pessoa humana.

Destarte, o ser humano assume, então, papel de destaque no conceito juscivilista e, no fim do século XX, surgem os direitos da personalidade aglutinados na Constituição Federal e no Código Civil de 2002. Interessante notar que os mesmos - ainda que os direitos da personalidade na Constituição tenham outra nomenclatura, como adiante se verá - não se encontram estanques, mas estão em um constante processo de entrelaçamento, de modo a propiciar a correta solução do caso concreto posto em juízo. 
Do exposto, depreende-se que o Direito Civil foi tomado por uma função humanizadora sem precedentes: houve a reanálise de velhos institutos, a superação de antigos dogmas e, assim, as relações privadas foram revestidas de nova roupagem.

Explicitado todo esse processo de humanização do Direito Civil, imperioso tecer comentários sobre as diferenças entre direitos fundamentais e direitos da personalidade. Ora, os direitos da personalidade não seriam, portanto, sinônimo de direitos fundamentais, mas, sim, espécie dos mesmos. Alguns dos direitos fundamentais elencados na Constituição Federal, mais afetos à seara do Direito privado, e que tutelam a personalidade humana, foram elencados ao longo do Código Civil e receberam o nome de direitos da personalidade (FEITOSA; COSTA; GODINHO, 2014, p. 27).

Partindo desta premissa, é fácil constatar que, mesmo diante da tutela um tanto tímida do Código Civil de 2002 no que tange aos direitos da personalidade, previstos apenas dos artigos 11 ao 21, há uma adequada proteção conferida pelo ordenamento a tais espécies de direitos não apenas por meio da aplicação horizontal dos direitos fundamentais ${ }^{4}$, mas, sobretudo, pelos mecanismos de filtragem constitucional, que permitem uma leitura do Direito Civil constitucionalizada. Há, portanto, o reconhecimento de dignidade na pessoa do indivíduo no âmbito do Direito Civil Constitucional.

\section{O direito à privacidade e a previsão de submissão obrigatória de identificação do perfil genético de condenados}

Compreendidos os direitos da personalidade como espécie dos direitos fundamentais, e tendo por norte que o indivíduo é dotado de uma dignidade a ele imanente, o artigo 21 do Código Civil de 2002 assegura que "a vida privada da pessoa natural é inviolável, e o juiz, a requerimento do interessado, adotará as providências necessárias para impedir ou fazer cessar ato contrário a esta norma”.

Destarte, nem o legislador, nem o constituinte não diferenciaram a privacidade da intimidade, conferindo à doutrina tal tarefa. Tanto a Constituição Federal, como o Código Civil

\footnotetext{
${ }^{4}$ Eficácia horizontal dos direitos fundamentais é vinculação de relações entre particulares a direitos fundamentais. Tais direitos foram concebidos originalmente como reguladores da relação entre Estado e particular. No entanto, essa visão mostrou-se, acentuadamente, limitada uma vez que se percebeu que nem sempre é o Estado que representa a maior ameaça aos direitos, mas sim outros particulares (SILVA, 2014, p. 18). Assim, os direitos fundamentais também regem as relações entre particulares em uma perspectiva de Constitucionalização do Direito Civil
} 
de 2002 não definiram ou sequer mencionam a palavra privacidade: sua existência é inferida através das expressões intimidade e vida privada.

De fato, a expressão privacidade é por demais ampla e se tornou uma "palavracamaleão", sendo utilizada para se referir a uma ampla gama de interesses radicalmente distintos (LEONARDI, 2009, p.46), de modo que merece disciplina no âmbito da doutrina para uma melhor delimitação do que se considera, de fato, direito fundamental constitucionalmente protegido. Há uma profusão de termos utilizados pela doutrina brasileira para representá-la: privacidade, vida privada, intimidade, segredo, sigilo, recato, privatividade e privaticidade, dentre outros (DONEDA, 2006, p 101).

Ademais, essa profusão de conceitos sobre o que seria privacidade não se reduz à dicotomia entre os modelos Civil Law e Common Law. Como explicitado por Marcel Leonardi, embora o sistema romano-germânico adote um conceito de privacidade baseado na dignidade da pessoa humana e o modelo anglo-saxão aproxime privacidade ao direito de liberdade, não haveria unidade de tratamento da privacidade dentro de um mesmo sistema jurídico, como se verifica na diversa delimitação desse direito nos Estados Unidos e Reio Unido (LEONARDI, 2009, ps.49-50)

Não há dúvida de que a privacidade é condição necessária para o livre desenvolvimento da personalidade, entretanto, a falta de clareza em sua definição cria embaraços no campo judicial, especialmente quando postos em choque direitos fundamentais no caso concreto, tais como segurança pública e liberdade de pensamento. Dessa forma, necessária uma adequada definição do que seria privacidade.

$\mathrm{Na}$ tentativa de diferenciar o que seria vida pública, privacidade e intimidade, o Tribunal Constitucional Alemão, baseando-se na doutrina de Heinrich Hubmann, foi preciso em desenvolver a teoria das esferas ou dos círculos concêntricos, também conhecida como "teoria da pessoa como cebola passiva" (DONEDA, 2006, p 108). Cabe salientar que, quanto mais próximo da esfera central da personalidade, mais rígidos são os limites à atuação estatal. Tal doutrina foi posteriormente abandonada, no que se refere à sua aplicação em tema de proteção de dados pessoais em uma célebre sentença de 1983 pelo próprio Tribunal Alemão ${ }^{5}$.

Hubmann utiliza um esquema de esferas concêntricas para representar os diferentes níveis de privacidade que o indivíduo poderia sentir em sua vida cotidiana: Öffentlichkentsbereich, a mais periférica, que corresponderia à vida pública; Privatphäre, a

\footnotetext{
${ }^{5} \mathrm{O}$ tema será tratado a seguir quando do desenvolvimento do que seria autodeterminação informativa.
} 
esfera da vida privada e, por fim, a Intimsphäre, também conhecida como Geheimnisphäre, a esfera mais recôndita, que seria a intimidade ou do segredo (DONEDA, 2006, p 108).

A esfera mais periférica é aquela que se pode denominar de vida pública ou social do indivíduo. São informações de amplo conhecimento da sociedade, ocorridas em locais públicos ou, até mesmo, prestadas pelo próprio indivíduo a toda a coletividade. Não têm proteção no âmbito da privacidade, uma vez que são de domínio público.

A segunda esfera é a da vida privada. Nela estariam todas as matérias relacionadas com notícias e expressões que o indivíduo deseja excluir do conhecimento de terceiros. Menciona-se como exemplo a imagem física, bem como comportamentos, ainda que ocorridos fora do domicílio, que só devem ser conhecidos por quem tem regular contato com a pessoa (ECHTERHOFF, 2010, p 140).

A esfera mais interior corresponderia à intimidade, espaço confidencial na vida do indivíduo. É o espaço do segredo, onde o indivíduo se apresenta realmente como é, uma vez que não tem o receio de tais informações se tornarem públicas. Em tal esfera, destaca-se a orientação sexual, assim como tudo aquilo que o indivíduo leva ao conhecimento de outra pessoa de sua confiança, excluído o público geral e aqueles pertencentes ao ciclo da vida privada e familiar. São assuntos que não devem chegar ao conhecimento de outros devido à sua natureza extremamente reservada.

Ainda no que pertine à difícil tarefa de diferenciar e delimitar o que seria intimidade, vida privada e privacidade, José Adércio defende que a diferença entre intimidade e vida privada decorreria dos bens ou valores a serem protegidos, como liberdade sexual, familiar e âmbito de informações pessoais. Dessa forma, ele salienta que a intimidade cuidaria do "âmbito das informações pessoais, do relacionamento comunicativo do ser com os demais, enfim, de uma autodeterminação informativa ou informacional" (SAMPAIO, 1998, p. 277).

Já Tércio Ferraz traz a diferenciação baseado de acordo com a esfera de proteção, de modo que a intimidade cuidaria do mais íntimo do ser humano, e a vida privada se referiria a algo menos restrito e mais aberto a terceiros, baseando-se na livre vontade do indivíduo (FERRAZ JÚNIOR, 1993, p 442).

Com efeito, depreende-se que o direito à privacidade é gênero, de modo a abarcar os conceitos de intimidade e de vida privada, ainda que haja uma certa controvérsia doutrinária sobre os precisos contornos do que estes últimos conceitos seriam.

A origem da feição moderna do direito à privacidade foi marcada por um individualismo exacerbado, sendo, até, egoísta (DONEDA, 2006, p.8), ao assumir a defesa do direito de ser deixado só - the right to be let alone. Ele foi formulado por Samuel Warren e 
Louis Brandeis, em 1890, ao publicarem o artigo The right to privacy. Apesar de em nenhum momento terem conceituado do que seria privacidade, os autores sustentam que o respeito à vida privada seria um abstenção, um respeito ao direito de estar só e tranqüilo.

Tal doutrina sustenta ser a privacidade uma espécie de imunidade do indivíduo perante terceiros, um isolamento social ou uma verdadeira privação (LEONARDI, 2009, p. 54). Seria marcada por uma "relação-zero", definida como a ausência de interação ou comunicação. Esse marco inicial do direito à privacidade muito influenciou a doutrina, mas merece reparos haja vista a privacidade apenas poder ser mensurada e classificada considerando seu aspecto relacional, ou seja, em um convívio em sociedade.

Em paralelo a esse conceito tradicional de privacidade, surgiu outro, também de natureza negativa, que a aproxima do direito de não sofrer interferências dos outros, sendo um direito de não-intromissão. Ele se diferencia do total isolamento da posição anterior, mas assegura ao "indivíduo manter seus assuntos para si e decidir por si mesmo em que medida eles serão submetidos à observação e discussão públicas" (LEONARDI, 2009, p. 56).

Posteriormente, uma célebre sentença do Tribunal Constitucional Alemão, em 1983, ao julgar uma lei do censo aprovada no ano anterior, utilizou a expressão "autodeterminação informativa" para designar o direito dos indivíduos de decidirem por si sós, quando e dentro de quais limites seus dados pessoais podem ser utilizados (DONEDA, 2006, p. 196). Na ocasião, tal direito foi concebido como um direito fundamental, na esteira do direito geral de personalidade (DONEDA, 2006, p. 197).

Assim, o direito à autodeterminação informativa é uma afirmação do personalismo e proporciona à pessoa o controle de suas informações. Nesse sentido, Stefano Rodotà afirma que o direito à privacidade seria, justamente, o "direito de manter o controle sobre as próprias informações e de determinar o modo de construção da própria esfera privada” (RODOTÀ, 2008, p. 139).

Aquele clássico direito à privacidade de não intromissão foi transformado no direito à autodeterminação informativa, o qual assegura ao titular o controle de suas informações, tanto em um aspecto negativo, como positivo (SAMPAIO, 1998, p. 495).

Essa faceta positiva cuida do direito do homem de controlar suas informações pessoais, não apenas impedindo a sua utilização, como também tendo o controle das informações constantes em arquivos públicos e privados (ECHTERHOFF, 2010, p 152).

Ressalte-se, então, que aquele aspecto clássico ainda persiste, diante da necessidade de não tornar público certos acontecimentos ou comportamentos. Além desse aspecto, garantese o direito de o indivíduo ter pleno controle de suas informações pessoais constantes em bancos 
de dados, sendo-lhe assegurada a escolha das informações a serem armazenadas, bem como sua retificação ou cancelamento (ECHTERHOFF, 2010, p 155).

Isto posto, cabe destacar que as informações pessoais podem ser nominativas, quando referentes a uma pessoa determinada, e não nominativas, que são os dados não relacionados ou identificados a pessoas determinadas. Em relação aos dados nominativos, estes subdividem-se em dados sensíveis e não-sensíveis, os quais seriam aqueles não reservados ao seu titular. Como exemplos, mencionam-se dados atinentes à qualificação da pessoa, como nome, estado civil, profissão, domicílio, dentre outros. Tais dados não geram danos ou risco de dano ao seu titular.

Já os dados sensíveis são aqueles ligados diretamente à privacidade do indivíduo e que, se utilizadas, podem acarretar utilização discriminatória ou lesiva ao titular (DONEDA, 2006, p. 160). Como exemplo, menciona-se a preferência sexual da pessoa, condições de saúde, dados genéticos, ideologias, crenças religiosas, bem como traços de seu caráter e personalidade. Dessa forma, gozam de maior proteção jurídica, de modo que o titular podem, além de controlar seu armazenamento, uso e veracidade, impedir totalmente sua utilização (ECHTERHOFF, 2010, p 157).

Desta feita, a proteção dos dados pessoais é um dos aspectos do direito à privacidade. Haveria, então, um direito à autodeterminação informativa em que o indivíduo escolhe o que compartilhar acerca de seus dados e com quem. Assim, a proteção de dados pessoais pode se circunscrever à esfera da vida privada (quando o titular dos dados os compartilha com familiares ou amigos íntimos), bem como à da intimidade (hipótese em que o indivíduo restringe os dados a si próprio).

Nesse sentido, a privacidade atualmente assume um caráter relacional, no qual se deve determinar o nível de relação da própria personalidade com as outras pessoas e com o mundo exterior (DONEDA, 2006, p. 144). Ademais, sendo concebido como um direito fundamental, na esteira do direito da personalidade, o direito à autodeterminação informativa proporciona ao indivíduo o controle sobre suas informações (DONEDA, 2006, p. 197)

Explicitada a tutela jurídica da privacidade, impõe-se discorrer acerca da Lei $12654 / 2012^{6}$ que previu a submissão obrigatória de condenados em crimes hediondos à identificação do perfil genético, mediante a extração de DNA, por meio de técnica indolor,

\footnotetext{
${ }^{6}$ Art. $9^{\circ}$-A. Os condenados por crime praticado, dolosamente, com violência de natureza grave contra pessoa, ou por qualquer dos crimes previstos no art. $1^{\circ}$ da Lei $\mathrm{n}^{\circ}$ 8.072, de 25 de julho de 1990 , serão submetidos, obrigatoriamente, à identificação do perfil genético, mediante extração de DNA - ácido desoxirribonucleico, por técnica adequada e indolor. $\S 1^{\circ} \mathrm{A}$ identificação do perfil genético será armazenada em banco de dados sigiloso, conforme regulamento a ser expedido pelo Poder Executivo. $2^{\circ}$ A autoridade policial, federal ou estadual, poderá requerer ao juiz competente, no caso de inquérito instaurado, o acesso ao banco de dados de identificação de perfil genético. (BRASIL, 2016)
} 
criando-se o banco genético de dados de condenados. O recolhimento do material genético darse-á como conseqüência da condenação, não havendo previsão de exclusão de tais perfis genéticos, nem ao término do prazo prescricional.

Diante o quadro acima apresentado é de se questionar se essa submissão obrigatória ao fornecimento de material genético, tal qual prevista em lei, constitui uma violação aos direitos fundamentais da privacidade e da autodeterminação informativa. Será o código genético um dado sensível, apenas sendo possível sua revelação com o consentimento do indivíduo?

Para ampliarmos o debate, podemos suscitar que a legislação previu que a identificação genética não poderia revelar traços somáticos ou comportamentais das pessoas, exceto determinação de gênero, o que, em tese, preservaria a privacidade do indivíduo. Ademais, a adoção do banco de dados genéticos poderia ajudar na identificação criminal dos investigados, mormente em um sistema precário como o que vige no Brasil, em que, muitas vezes, não se consegue identificar corretamente um suspeito.

A legislação assegura que tais dados serão mantidos no âmbito da Administração Pública de forma a manter o sigilo quanto aos mesmos. Ressalva que as informações genéticas serão utilizadas para fins de investigação criminal ou identificação de pessoas desaparecidas (artigo 8 ${ }^{\mathbf{0}}$, Decreto 7950/2013).

Diante dessa inovação legislativa, surgiu um amplo debate no meio acadêmico quanto à constitucionalidade dessa medida. Constata-se, assim, um embate entre o direito à privacidade, considerando a autodeterminação informativa, e a segurança pública e a necessidade de controle da criminalidade, cada vez maior em nosso cotidiano.

Tal discussão transpôs as fronteiras dogmáticas e chegou ao STF por meio do RE 973.837 que teve sua repercussão geral reconhecida. O colegiado entendeu, por unanimidade, que a manutenção de perfil genético de condenados em banco de dados estatal não seria aceita, de forma unânime, como compatível com os direitos de personalidade e os direitos fundamentais previstos no artigo $5^{\mathbf{0}}$ da Constituição.

\section{A dignidade da pessoa do condenado como paradigma}

Constata-se que esse debate ocorre em âmbito internacional. O Tribunal Europeu de Direitos Humanos já se deparou com inúmeros casos acerca do limite estatal quanto ao armazenamento de dados genéticos do indivíduo, bem como à submissão obrigatória ao fornecimento de material genético. Quando julgava, o caso Van der Vekden vs Holanda, 
processo 29514, considerou uma invasão à privacidade do indivíduo a colheita por meio de esfregação de cotonete na parte interna da bochecha. (FRANÇA, TEDH, 2006).

O próprio Supremo Tribunal Federal, no que tange à tutela do corpo e do material genético individual, já se deparou com algumas situações conflitantes. Entre elas, a obrigatoriedade de realização de exame de DNA para se aferir a paternidade, em que se vislumbra a ponderação entre a intimidade e o direito fundamental à paternidade. $\mathrm{Na}$ oportunidade, o $\mathrm{STF}^{7}$ entendeu pela impossibilidade, acolhendo a precedência, em tais situações, da intangibilidade do corpo, intimidade e dignidade da pessoa humana.

Já no caso Gloria Trevi ${ }^{8}$, no qual a intimidade se contrapunha à honra e imagem da Polícia Federal, o Pretório Excelso autorizou que fosse realizado exame de DNA na placenta da extraditanda, pois entendeu que o esclarecimento da verdade quanto à participação de policiais em suposto estupro maculava a imagem da própria Polícia Federal. Cabe frisar que, na decisão, salientou-se a preservação da integridade física e da intimidade da custodiada e de seu filho, haja vista a extração de DNA da placenta após o parto, material que, não obstante seja orgânico, seria descartado pelo hospital (BRASIL, STF, 2002).

No conflito em questão, o direito à privacidade se contrapõe à prevenção/ repressão de crimes. Há quem sustente que os condenados em crimes hediondos não teriam assegurados todos os direitos da personalidade, em especial o direito à autodeterminação informativa. Entretanto, faz-se mister responder ao seguinte questionamento: o Estado estará cumprindo realmente o seu papel de garantir os direitos básicos do cidadão ao relativizar o direito fundamental à privacidade em prol de uma segurança maior à coletividade?

Caso se responda positivamente a esse questionamento, estar-se-á condenando indivíduos sentenciados em crimes hediondos a serem verdadeiros homo sacer modernos, nas brilhantes palavras de Georgia Amitrano que, ao resgatar o conceito de Giorgio Agamben, assim explica a expressão:

\footnotetext{
7 INVESTIGAÇÃO DE PATERNIDADE - EXAME DNA - CONDUÇÃO DO RÉU "DEBAIXO DE VARA". Discrepa, a mais não poder, de garantias constitucionais implícitas e explícitas - preservação da dignidade humana, da intimidade, da intangibilidade do corpo humano, do império da lei e da inexecução específica e direta de obrigação de fazer - provimento judicial que, em ação civil de investigação de paternidade, implique determinação no sentido de o réu ser conduzido ao laboratório, "debaixo de vara", para coleta do material indispensável à feitura do exame DNA. A recusa resolve-se no plano jurídico-instrumental, consideradas a dogmática, a doutrina e a jurisprudência, no que voltadas ao deslinde das questões ligadas à prova dos fatos. (BRASIL, STF, 1996)

${ }^{8}$ Caso de grande repercussão da mídia em que uma extraditanda, a cantora mexicana Gloria Trevi, custodiada na Polícia Federal e sem direito a visitas íntimas, surge grávida, acusando policiais federais de estupro. Como ela se recusava a indicar quem seria o estuprador e a fazer exame de DNA, a Polícia Federal teve que instaurar investigação em relação a todos os agentes que trabalhavam no local, de modo que a imagem da própria Polícia Federal restaria abalada sem o deslinde da controvérsia.
} 
o termo sacer indica o enigma de uma figura aquém ou além do religioso, uma figura obscura do Direito romano arcaico, que foi julgada por delito, e que, a partir disso, não é considerada pura e não pode ser oferecida em sacrifício; porém, se for assassinada, seu assassino não é considerado um homicida. (AMITRANO, 2013, p. 80)

Agamben retoma a expressão saceresto - impune occidi, que indica exclusão do sacrifício, e o termo Sacrum, que indica o que é destinado aos deuses. Disso decorre a dificuldade conceitual do significado do termo homo sacer, na medida em que, enquanto é vetado violar coisas sacras, é lícito matar homem sacro. Para o referido autor, a vida humana do homo sacer seria incluída no ordenamento unicamente sob a forma de exclusão, ou seja, de sua absoluta matabilidade (AGAMBEN, 2010, p 16). Com efeito, a pessoa seria simplesmente posta para fora da jurisdição humana, sem ultrapassar para a divina (AGAMBEN, 2010, p 83). O indivíduo estaria, nesse sentido, desprovido de direitos e de tutela estatal.

Assim, condenados seriam indivíduos desprovidos de abrigo Estatal, de dignidade humana, entregues à própria sorte e desprovidos de Direitos Fundamentais. Nesse sentido, colaciono:

(...) mas recentemente, recriam-se na Europa figuras (...) que traduzem novas versões do velho homo sacer do Direito Romano (...) Todos eles ganham, na sua nãosignificância e no seu desvalor, um significado e um lugar. (...) são marcados como os seres de vida nua: insacrificáveis, mas matáveis. Nos espaços de uma geografia do reconhecimento do mesmo, existe um território próprio no qual se marcam os indivíduos em um processo contínuo de rejeição e eliminação do outro (AMITRANO, 2013, p. 86)

Assim, ao se desprover um condenado de seu direito à privacidade, tornando obrigatória a sua submissão à identificação de perfil genético, com o intuito de proporcionar uma maior segurança pública à coletividade, o Estado acaba por torná-lo um indivíduo de segunda categoria, esquecendo-se de que seu valor intrínseco, inerente a todo ser humano, não desaparece apenas em função da natureza grave do crime cometido, ou de seu encarceramento. Cabe ressaltar que cabe ao Estado assegurar o respeito à dignidade de cada pessoa, e não escolher quais indivíduos merecem a proteção de seus direitos.

Importante salientar, que a mudança no direito privado mencionada no processo de Constitucionalização do Direito, também alterou a maneira de encarar o sujeito de direitos. Este não desaparece, ele é ressignificado. E, uma vez identificados grupos de não iguais, de vulneráveis, acabam por modificar as instituições em que estão ao receberem direitos fundamentais (MARQUES; MIRAGEM, 2014). Assim, tendo por norte essa repersonalização 
do direito privado, a pessoa do condenado, um vulnerável que se encontra à mercê do Estado, deve ser protegida e ter seus direitos de personalidade respeitados pela legislação.

No que tange à igualdade entre indivíduos, não se vislumbra razão plausível para diferenciar os direitos da personalidade de pessoas condenadas em crimes hediodos, que, em função desse fato, não teriam assegurado o direito à privacidade. Boaventura de Sousa Santos acrescenta:

(...) temos o direito a ser iguais quando a nossa diferença nos inferioriza; e temos o direito a ser diferentes quando a nossa igualdade nos descaracteriza. Daí a necessidade de uma igualdade que reconheça as diferenças e de uma diferença que não produza, alimente ou reproduza as desigualdades. (2003, p. 56)

O que se observava no direito privado anterior era uma igualdade formal, em abstrato, encontrada apenas em livros. Já hoje, no novo direito privado, exige-se uma igualdade material ou substancial, que ocorra na prática. Para tanto, a igualdade como ideal do Justo necessita dos direitos humanos ou fundamentais, tendo como vetor a dignidade da pessoa humana (MARQUES; MIRAGEM, 2014).

Isto posto, compreende-se que no direito privado a pessoa não deve ser apenas livre (fator liberdade), deve ser também igual, formal e materialmente (fator igualdade). A igualdade só terá efetividade "uma vez que se reconheçam situações estruturais de desigualdade e se protejam os vulneráveis (...) este é o sentido dos direitos fundamentais”. (MARQUES; MIRAGEM, 2014, p. 131).

O homem, em especial um indivíduo vulnerável condenado por um crime hediondo, deve ser visto como portador de uma dignidade inata e inviolável. A utilização dos dados genéticos para a prevenção e repressão criminal não justifica a submissão obrigatória do indivíduo à identificação de perfil genético. Afinal, nos termos do imperativo categórico, o homem jamais pode ser usado como meio para se atingir um determinado fim (KANT, 1959), independentemente da nobreza desse desiderato. Tão-somente o indivíduo deve ser considerado um fim em si mesmo e, como tal, deve ser protegido. Precisas são as palavras de Maria Celina Moraes:

Isto significa que todas as normas decorrentes da vontade legisladora dos homens precisam ter como finalidade o homem, espécie humana como tal. O imperativo categórico orienta-se, então, pelo valor básico, absoluto, universal e incondicional da dignidade humana. É esta dignidade que inspira a regra ética maior: o respeito pelo outro (MORAES, 2003, p. 115)

Em continuidade, no que tange à difícil tarefa de conceituação do que seja a dignidade da pessoa humana, Maria Celina Moraes ressalta que não cabe ao ordenamento jurídico 
conceituá-la, ou mesmo à Constituição Federal fazê-lo. Para a referida autora, ao Direito cabe enunciar o princípio, cristalizado na consciência coletiva, dispondo sobre sua tutela, através de direitos e garantiam que assegurem a concretização da referida clausula geral ${ }^{9}$ (MORAES, 2003, p. 116).

Assim, ao retomar os postulados axiológicos de Kant, a referida autora defende que o substrato material da dignidade da pessoa humana se desdobra em quatro postulados, quais sejam: igualdade, integridade psicofísica, liberdade e solidariedade (MORAES, 2003, p.119).

No que tange à igualdade, como vimos, deve-se promover uma igualdade substancial entre indivíduos, de modo a mitigar a vulnerabilidade nos mais diversos grupos da sociedade. Em continuidade, a liberdade deve ser compreendida como a possibilidade de a pessoa realizar suas próprias escolhas, sem interferências, exercendo o direito de viver como melhor lhe aprouver. A solidariedade é a garantia de o homem não ser marginalizado por seus iguais.

Tradicionalmente, a integridade psicofísica do indivíduo, uma conquista ético-jurídica oriunda da reação dos povos contra as atrocidades cometidas pelos regimes totalitários contra milhões de pessoas durante a Segunda Guerra Mundial (DIAS, 2016), é associada ao direito de não ser torturado e de não sofrer penas cruéis, dentre outras garantias. Na órbita civil, associase esse postulado aos inúmeros direitos da personalidade previstos ou não no ordenamento jurídico, como vida, imagem, honra privacidade e corpo, dentre outros. Especificamente quanto ao direito à privacidade, o tema de proteção de dados genéticos é uma das facetas desse direito (MORAES, 2003, p. 128) em função da importância desses dados sensíveis.

Nesse sentido, a proteção dos dados genéticos do indivíduo se insere no âmbito de proteção da dignidade da pessoa humana, sendo uma concretização desse direito assegurado na Constituição Federal. Diferenciar indivíduos que merecem proteção quanto aos dados genéticos em função de cometimento de crimes graves viola a dignidade inerente e inalienável a todos os seres humanos.

\section{Considerações finais}

O novo direito privado, atual, pós-moderno e contemporâneo, tem como fim uma maior proteção da pessoa humana em seus mais diversos aspectos. Calcado na promoção de

\footnotetext{
${ }^{9}$ Nas cláusulas gerais, além da hipótese de incidência ser composta por termos indeterminados, as normas não prefixam soluções ou conseqüências, cabendo ao juiz também defini-las. Como exemplo de cláusula geral, cita-se o artigo 421 do Código Civil. A norma, que prevê a função social do contrato, não define o seu sentido exato da expressão e também não fixa as soluções ou conseqüências pertinentes.
} 
uma igualdade substancial, busca a proteção dos vulneráveis através da construção de um sistema que reconheça e efetive os seus direitos.

Nesse ambiente de um renovado humanismo, a vulnerabilidade do homem será tutelada mediante a clausula geral de dignidade da pessoa humana, constante da Constituição Federal de 1988. Desta feita, grupos considerados frágeis merecem especial proteção por parte do Direito, inclusive no que tange aos direitos de personalidade, expressão civilista de direitos humanos e fundamentais.

Sob essa ótica, a lei 12.654/2012, ao determinar a sujeição obrigatória de pessoas condenadas em crimes hediondos à identificação de perfil genético, mediante a extração de DNA, viola os direitos da personalidade do indivíduo pois, ao não respeitar a sua livre vontade no que pertine ao fornecimento de seus dados sensíveis, vulnera a sua própria condição de ser humano dotado de direitos inalienáveis.

A privacidade, hoje, é compreendida como direito fundamental à autodeterminação informativa e, nesse sentido, a pessoa condenada em crime hediondo tem o direito de se recusar ao fornecimento de seus dados genéticos imposto pela lei. $\mathrm{O}$ fato de ter cometido um crime sujeito à censura e reprimenda estatal não torna o indivíduo desprovido de um valor e de direitos fundamentais a ele inerentes.

Muito mais do que entender o direito à privacidade dos dados genéticos da pessoa do condenado como uma questão meramente objetiva, é imperioso compreender que a finalidade da proteção deste direito consiste na proteção da esfera privada, na busca da consagração da dignidade da pessoa humana (ECHTERHOFF, 2010, p 155). Negar o reconhecimento desse direito, além de ser um perigoso precedente para os demais indivíduos, acaba por vulnerar ainda mais os direitos de pessoas condenadas, consistindo uma grave violação à dignidade da pessoa humana.

\section{Referências bibliográficas}

AGAMBEN, Giorgio. Homo sacer: o poder soberano e a vida nua i. Belo Horizonte: Editora UFMG, 2010.

AMITRANO, Georgia. O paradoxo do homo sacer: entre o abandono e o bando. Disponível em: <http://www.revistas.usp.br/cefp/article/view/74747/78338>. Acesso em 12 dez 2016. 
BARROSO, Luis Roberto. Neoconstitucionalismo e a constitucionalização do direito.

Disponível em $:<$ http://bibliotecadigital.fgv.br/ojs/index.php/rda/article/view/43618>. Acesso em 25 abr 2018.

BRASIL. Lei 10.406, de 10 de janeiro de 2002. Código Civil. Brasília, 2002. Disponível em: $<$ http://www.planalto.gov.br/ccivil_03/leis/2002/110406.htm>. Acesso em 04 de junho de 2016.

BRASIL. Supremo Tribunal Federal. HC 71.373/SP, Relator: Ministro Marco Aurélio de Mello, Brasília, 10 de novembro de 1996. Disponível em: <http://www.stf.jus.br/portal/ processo/verProcessoAndamento.asp?incidente=1585884 $>$ Acesso em 21 nov. 2016.

BRASIL. Supremo Tribunal Federal. MS 23.669/DF, Relator: Ministro Celso de Melo, Brasília, 12 de abril de 2000. Disponível em: <http://www.stf.jus.br/portal/ processo/verProcessoAndamento.asp?incidente=1816436>Acesso em 21 nov. 2016.

BRASIL. Supremo Tribunal Federal. Rcl 2040/DF, Relator: Ministro Neri da Silveira, Brasília, 21 de fevereiro de 2002. Disponível em: <http://www.stf.jus.br/portal/ processo/verProcessoAndamento.asp?incidente=1997002> Acesso em 21 nov. 2016.

CANOTILHO, J. J. Gomes; MOREIRA, Vital Martins. Fundamentos da Constituição. Coimbra: Coimbra Ed., 1991

DIAS, Clara Angélica Gonçalves Cavalcante. Responsabilidade civil do empregador diante dos riscos sociais que afetam a saúde e a integridade física do empregado. Paraná: CRV, 2016

DONEDA, Danilo. Da privacidade à proteção de dados pessoais. Rio de Janeiro: Renovar, 2006.

ECHTERHOFF, Gisele. Direito à privacidade dos dados genéticos. Curitiba: Juruá, 2010 
FEITOSA, Maria Luiza Pereira de Alencar Mayer; COSTA, Ana Paula Correia de Albuquerque, GODINHO, Adriano Marteleto. Humanização do direito civil constitucional:perspectivas e desafios. Florianópolis: Conceito, 2010.

FERRAZ JÚNIOR, Tércio Sampaio. Sigilo de dados: o direito à privacidade e os limites à função fiscalizadora do estado. Revista da Faculdade de Direito da Universidade de São Paulo, v. 88, p. 439-459, 1993

FRANÇA. Tribunal Europeu dos Direitos Humanos. Processo 29514. Strasbourg, 7 de dezembro de 2006. Disponível em<http://hudoc.echr.coe.int/eng\#\{\%22appno\%22:\% 5B\%2229514/05\%22\%5D,\%22itemid\%22:\%5B\%22001-78858\%22\%5D\}>. Acesso em: 21 nov. 2016.

KANT, Immanuel. Crítica da razão prática. São Paulo: Brasil Editora, 1959.

LEONARDI, Marcel . Tutela e privacidade na internet. São Paulo: Saraiva, 2009.

MARQUES, Cláudia Lima; MIRAGEM, Bruno. O novo direito privado e a proteção dos vulneráveis. 2. ed. São Paulo: Revista dos Tribunais, 2014.

MENDES, Gilmar Ferreira; BRANCO; Paulo Gustavo Gonet. Curso de direito constitucional. 3. ed. São Paulo: Saraiva, 2011.

MORAES, Maria Celina Bodin de. O conceito de dignidade humana: substrato axiológico e conteúdo normativo. In: SARLET, Ingo Wolfgang (Coord.). Constituição, direitos fundamentais e direito privado. Porto Alegre: Livraria do Advogado, 2003.

Danos à pessoa humana: uma leitura civil-constitucional dos danos morais. Rio de Janeiro: Renovar, 2003.

ONU. Declaração Universal dos Direitos do Homem. Disponível em: <http://www.onubrasil.org.br/documentos_direitoshumanos.php>. Acesso em 19 novembro 2016. 
RODOTÀ, Stefano. A vida na sociedade de vigilância: a privacidade hoje. Rio de Janeiro: Renovar, 2008.

SAMPAIO, José Adércio Leite. Direito à intimidade e à vida privada: uma visão jurídica da sexualidade, da família, da comunicação e informações pessoais, da vida e da morte. Belo Horizonte: Del Rey, 1998.

SANTOS, Boaventura de Sousa. Reconhecer para libertar: os caminhos do cosmopolitanismo multicultural. Introdução: para ampliar o cânone do reconhecimento, da diferença e da igualdade. Rio de Janeiro: Civilização Brasileira, 2003.

SILVA, Virgílio Afonso da. A constitucionalização do direito: os direitos fundamentais nas relações entre particulares. São Paulo: Malheiros, 2014.

SOUZA NETO, Cláudio Pereira de; SARMENTO, Daniel. A constitucionalização do direito: fundamentos teóricos e aplicações específicas. Rio de Janeiro: Lumen Juris, 2007.

SUPIOT, Alain. Homo juridicus ensaio sobre a função antropológica do direito. São Paulo: Martins Fontes, 2007.

WOLKMER, Antonio Carlos (Coord). Fundamentos do humanismo jurídico no ocidente. Barueri: Manole Editora, 2005.

TEPEDINO, Gustavo (Coord.). A parte geral do novo código civil: estudos na perspectiva civil-constitucional. Rio de Janeiro: Renovar, 2002. 


\title{
A SEGURANÇA JURÍDICA DA USUCAPIÃO EXTRAJUDICIAL EM FACE DO PROCEDIMENTO JUDICIAL
}

Dênio Guilherme dos Reis

Faculdade de Ciências Humanas, Sociais e da Saúde da Universidade FUMEC

\begin{abstract}
Resumo
O presente trabalho analisa o procedimento da usucapião judicial no Código de Processo Civil de 1973, bem como a inovação trazida pelo novo Código de Processo Civil, que insere na Lei de Registros Públicos o procedimento administrativo para usucapião extrajudicial. Traz as similitudes e diferenças entre ambos os procedimentos para investigar o procedimento desjudicializado da usucapião, com o escopo de demonstrar que ela oferece a mesma segurança jurídica da via judicial. O presente artigo foi desenvolvido por meio de pesquisa bibliográfica, na vertente dogmática-jurídica e tipo comparativo de investigação jurídica.
\end{abstract}

Palavras-chave: Usucapião judicial, Usucapião extrajudicial, Segurança jurídica, Novo Código de Processo Civil, Registros Públicos e Registro de Imóveis.

\begin{abstract}
Resumen/Résumé
This present work analyzes the procedure of judicial usucaption in the Civil Procedure Code of 1973, as well as the innovation brought by the new Civil Procedure Code, which inserted in the Public Registers Law the administrative procedure for extrajudicial usucaption. It draws the similarities and differences between the two procedures and in this comparative analysis, more specifically, it investigates whether in the unjustified procedure of usucapion, it offers the same legal certainty as in judicial proceedings. The present article was developed through theoretical research adopting the dogmatic juridical aspect of the investigation.
\end{abstract}

Keywords/Palabras-claves/Mots-clés: Judicial usucaption, Extrajudicial usucaption, Legal security, New Code of Civil Procedure, Public Records and Real Estate Registry. 


\section{Introdução}

A Lei $n^{0} 13.105$, de 16 de março de 2015, que introduziu o atual Código de Processo Civil (CPC) inseriu o art. 216-A na Lei de Registros Públicos, trazendo consigo o procedimento comum de usucapião extrajudicial, reconhecendo e oficializando o domínio sobre áreas de terra, tanto urbanas como rurais, de forma administrativa. Tal procedimento administrativo, considerado constitucional, ${ }^{1}$ é realizado junto ao Cartório de Registro de Imóveis com a colaboração do Tabelionato de Notas. É também denominado procedimento “desjudicializado", ou seja, executado fora do âmbito judicial.

A partir dessa premissa surge a necessidade de compreensão dos componentes que integram o instituto da usucapião extrajudicial, que se destina a garantir operações de transferência de propriedade sobre bens imóveis que antes eram prerrogativas exclusivas do judiciário. Isto porque, ao inovar no sistema jurídico, a mencionada legislação traz uma nova forma de usucapir que promete mais celeridade no procedimento, sem a necessidade de buscar a esfera judicial.

Assim, o presente artigo faz uma análise referente ao procedimento da Usucapião Judicial contido no Código de Processo Civil de 1973, bem como no procedimento da Usucapião Extrajudicial, inovação trazida pelo Novo Código de Processo Civil. Neste seguimento delineia historicamente a evolução do procedimento desjudicializado no Brasil e a natureza jurídica deste instituto. Traz as similitudes e diferenças entre os dois procedimentos da usucapião, de forma a responder à pergunta objeto do presente artigo, qual seja: $\mathrm{O}$ procedimento administrativo da usucapião introduzido pelo Novo Código Processo Civil é capaz de oferecer a mesma segurança jurídica que uma sentença declaratória de usucapião judicial?

A investigação foi realizada utilizando a vertente dogmática-jurídica, levando em conta a pretensão de demonstrar, por meio de uma abordagem metodológica, os dilemas que envolvem o procedimento da Usucapião Extrajudicial, bem como a prevalência da segurança jurídica na desenvoltura deste procedimento.

Trata-se de pesquisa teórica, portanto o procedimento adotado para definição das especificidades foi a análise de normas e de textos doutrinários, recolhidos por meio de pesquisa

\footnotetext{
${ }^{1}$ [...] não há qualquer óbice constitucional em levar para outro órgão, que não o judicial, o reconhecimento da usucapião, desde que, obviamente, não se afronte o insculpido no art. $5^{\circ}$, XXXV, da Constituição Federal, isto é que não se exclua a possibilidade da discussão judicial do tema, se de natureza não jurisdicional for o órgão que receber a incumbência. BRANDELLI, Leonardo. Usucapião Administrativa de acordo com o novo Código de Processo Civil. São Paulo: Saraiva, 2016. p. 15.
} 
bibliográfica. Assim, para elaboração do estudo, foi utilizado o método jurídico-comparativo de forma a buscar as similitudes e diferenças entre os procedimentos judicial e extrajudicial da usucapião, utilizando dados primários e secundários, tais como: legislação, doutrina e jurisprudência.

Foi utilizado como referencial teórico do estudo o conceito de segurança jurídica, adotado por Humberto Ávila. Para o autor, segurança jurídica “[...] é um valor ético que antecede ao Estado e que este incorpora para gerar certeza, confiabilidade e estabilidade às relações sociais regidas pelo direito." ${ }^{2}$

Em consonância com esse conceito, foram citados diversos doutrinadores que patenteiam este ensinamento, encontrando uma conexão direta à novidade trazida pelo Código de Processo Civil, que é a possibilidade de se fazer a usucapião extrajudicial, de forma segura, eficaz e confiável, incorporando valores capazes de promover o bem da sociedade, pautado sempre na segurança jurídica.

\section{A usucapião judicial no código de processo civil de 1973}

O antigo Código de Processo Civil era dividido em quatro livros, sendo que o Livro IV, que versava sobre Procedimentos Especiais, era subdividido em Procedimentos Especiais de Jurisdição Contenciosa e de Jurisdição Voluntária. Dentre os Procedimentos Especiais de Jurisdição Contenciosa encontrava-se o Capítulo VII, "Da Ação de Usucapião de Terras Particulares". O Capítulo era composto de tão somente cinco artigos, in verbis:

\section{CAPÍTULO VII - DA AÇÃO DE USUCAPIÃO DE TERRAS PARTICULARES}

Art. 941. Compete a ação de usucapião ao possuidor para que se lhe declare, nos termos da lei, o domínio do imóvel ou a servidão predial.

Art. 942. O autor, expondo na petição inicial o fundamento do pedido e juntando planta do imóvel, requererá a citação pessoal daquele em cujo nome estiver registrado o imóvel usucapiendo, bem como dos confinantes e, por edital, dos réus em lugar incerto e dos eventuais interessados, observando quanto ao prazo o disposto no inciso IV do art. 232 (Redação dada pela Lei no 8951, de 13.12.1994).

Art. 943. Serão intimados por via postal, para que manifestem interesse na causa, os representantes da Fazenda Pública da União, dos Estados, do Distrito Federal, dos Territórios e dos Municípios. (Redação dada pela Lei nº 8.951, de 13.12.1994) Art. 944. Intervirá obrigatoriamente em todos os atos do processo o Ministério Público.

\footnotetext{
${ }^{2}$ ÁVILA, Humberto. Teoria dos princípios. Da definição à aplicação dos princípios jurídicos. 6. ed. São Paulo: Malheiros, 2006. p. 62.
} 
Art. 945. A sentença, que julgar procedente a ação, será transcrita, mediante mandado, no registro de imóveis, satisfeitas as obrigações fiscais. ${ }^{3}$

O procedimento judicial da usucapião encontrava-se regido no Código de Processo Civil de 1973, com a redação dada pela Lei $\mathrm{n}^{\circ} 8.951$ de 1994 , que trazia regras procedimentais para o feito. Por esta sistemática explica Leonardo Brandelli:

O reconhecimento da aquisição da propriedade imóvel pela usucapião, somente poderia dar-se na via jurisdicional, pelo Juízo competente, devendo este expedir mandado (art. 945 do CPC/73) ao Oficial do Registro de Imóveis com atribuição territorial para o ato, contendo os requisitos previstos nos artigos 226, 225 e 176 da Lei $n^{\circ} 6.015 / 1973$, para que este procedesse ao registro. ${ }^{4}$

A publicidade registral de sentença de procedência da usucapião, mediante mandado de registro, é que conferia publicidade contra terceiros acerca de tal aquisição e disponibilidade do direito real adquirido.

O processo inaugurava-se com a petição inicial, com descrição minuciosa do imóvel, sua confrontação, trazendo consigo planta e memorial descritivo do imóvel usucapiendo.

Pinheiro, ${ }^{5}$ ao expor sobre o procedimento judicial da usucapião, enfatiza que a petição inicial deverá conter o pedido devidamente fundamentado, trazendo em anexo a planta e memorial descritivo do imóvel, bem como o pedido de citação em nome de quem estiver registrado o imóvel a ser usucapido e dos confinantes. Os cônjuges do proprietário e dos confrontantes também deveriam ser incluídos no polo passivo processual, e, portanto, citados.

Deveriam ser citados por edital os réus (proprietário tabular e confrontantes) em lugar incerto e não sabido, caso em que lhes deveria ser nomeado curador, bem como os eventuais interessados. ${ }^{6}$

Qualquer pessoa que exercesse de fato a posse teria legitimidade ativa para figurar como usucapiente no procedimento judicial da usucapião. Em se tratando de absolutamente incapaz far-se-ia necessária a devida representação ou assistência, por quem a lei indicar, no caso de relativamente incapaz.

Afirma Pinheiro $^{7}$ que a citação dos representantes da Fazenda Pública da União, dos Estados, do Distrito Federal, dos territórios e dos municípios, para que se manifestasse interesse

\footnotetext{
${ }^{3}$ BRASIL. Lei n ${ }^{\text {5 5.869, de }} 11$ de janeiro de 1973. Código de Processo Civil. Diário [da] República Federativa do Brasil. Brasília, 11 de jan. 1973. Disponível em: < http://www.planalto.gov.br/ccivil_03/Leis/L5869 impressao.htm>. Acesso em: 10 mai. 2018.

${ }^{4}$ BRANDELLI, op. cit., p. 68.

${ }^{5}$ PINHEIRO, Fábio Monteiro. Usucapião de bens imóveis. Revista Eletrônica Direito, Justiça e Cidadania. v. 2, n. 1, 2011.

${ }^{6}$ WAMBIER, Luiz Rodrigues; TALAMINI, Eduardo. Curso avançado de processo civil. 14. ed. São Paulo: Revista dos Tribunais, 2015. v. 3, p. 337.

${ }^{7}$ PINHEIRO, op. cit.
} 
na causa, era feita por via postal, em conformidade com o art. 943 do Código Processo Civil de 1973.

O Ministério Público tinha sua intervenção garantida em todas as fases do processo, atuando como fiscal da lei, ou seja, custos legis, não como parte ou substituto processual nas ações da usucapião. Segundo afirma Carlos de Moraes Salles, a ação de usucapião consubstancia causa tipicamente de interesse público, evidenciado pela natureza da lide, pois é ação dirigida, em princípio, contra todos, contra a coletividade. ${ }^{8}$ Consoante o art. 83 do referido CPC, o órgão ministerial teria vista dos autos depois das partes e a falta de sua intimação acarretaria a nulidade do processo.

Contudo, o Conselho Nacional do Ministério Público (CONAMP), com a edição da Recomendação $\mathrm{n}^{\mathrm{o}} 16$, de 2010, art. $5^{\circ}$, vigente à época, minimizou a participação do órgão ministerial nas ações de usucapião de bens imóveis registrados ou de coisa móvel, tornando-a facultativa. Diante dessa faculdade, o juiz, sob pena de nulidade, abria vista ao membro do Ministério Público, e este, por sua vez, decidia sobre sua participação ou não no feito.

A sentença proferida no processo da usucapião é de cunho declaratório, tendo como objeto a declaração da aquisição da propriedade do imóvel usucapiendo. A aquisição se dá no momento da consumação do prazo prescricional. Neste sentido o professor José Carlos de Moraes Salles discorre que a ação de usucapião é declaratória de um direito preexistente, não tendo caráter constitutivo, uma vez que a usucapião se consubstancia desde o momento em que o usucapiente consegue reunir todos os requisitos estabelecidos na lei para esse fim. ${ }^{9}$

Dentre esses requisitos não se encontram nem a sentença nem o seu registro, pois a primeira simplesmente declara um direito preexistente e o segundo serve para dar publicidade originária operada pela usucapião, resguardando a boa-fé de terceiros, possibilitando, por parte o usucapiente, o exercício de jus disponendi e assegurando, ainda, a continuidade do registro.

\section{A usucapião extrajudicial no novo código de processo civil}

O Novo Código de Processo Civil, de 16 de março de 2015, ${ }^{10}$ trouxe como inovação o procedimento administrativo para a usucapião extrajudicial ao inserir no Capítulo II, Título

\footnotetext{
${ }^{8}$ SALLES, José Carlos de Moraes. Usucapião de bens imóveis e móveis. 6. ed. Rio de Janeiro: Revista dos Tribunais, 2006, p. 246.

${ }^{9}$ Ibidem, p. 174.

${ }^{10}$ BRASIL. Lei ${ }^{\circ} 13.105$, de 16 de março de 2015. Código de Processo Civil. Diário [da] República Federativa do Brasil. Brasília, 17 de mar. 2015. Disponível em: <https:/www.planalto.gov.br/ccivil_03/_a to20152018/201 5/lei/113105.htm>. Acesso em: 19 out. 2016.
} 
V, da Lei $n^{o} 6.015$ de 31 de dezembro de $1973^{11}$ o artigo 216-A. Tal possibilidade, embora abordada com mais ênfase no novo codex e no artigo supramencionado, já se fazia presente no art. 60, caput, da Lei $n^{\circ} 11.977$, de julho de 2009, revogado pela Lei n. $^{\circ}$ 13.465/2017, que dispunha sobre o Programa Minha Casa Minha Vida e previa que:

Art.60- Sem prejuízo dos direitos decorrentes da posse exercida anteriormente, o detentor do título de legitimação de posse, após 5 (cinco) anos de seu registro, poderá requerer ao oficial de registro de imóveis a conversão desse título em registro de propriedade, tendo em vista sua aquisição por usucapião, nos termos do art. 183 da Constituição Federal. ${ }^{12}$

Contudo, o Novo Código de Processo Civil tratou de generalizar o procedimento levando em conta alguns critérios pré-estabelecidos e ampliando assim a sua aplicabilidade na forma extrajudicial a contar com os serviços públicos que visam garantir a publicidade, autenticidade, segurança e eficácia aos atos jurídicos.

Faz-se mister salientar a importância dessa cooperação uma vez que a Constituição da República Federativa do Brasil de $1988{ }^{13}$ em seu artigo 236, dispõe que "[...] os serviços notariais e de registro são exercidos em caráter privado, por delegação do poder público" e a Lei $\mathrm{n}^{\circ} 8.935$, de 18 de novembro de 2014, que regulamenta o artigo supra, dispondo sobre serviços notariais e registrais orienta, em seu artigo $3^{\circ}$, que “[...] o notário, ou tabelião, e oficial de registro, ou registrador, são profissionais do direito, dotados de fé pública, a quem é delegado o exercício da atividade notarial e de registro".

Visando a aplicabilidade da usucapião extrajudicial como estratégia jurídica, que visa conferir celeridade às demandas sociais ${ }^{14}$ foi acrescido à Lei de Registros Públicos o art. 216A regulando o procedimento da Usucapião Administrativa que segue um rito próprio perante o oficial de Registro de Imóveis no cartório de circunscrição do imóvel usucapiendo.

Certo é que a iniciativa constante no novo $\operatorname{codex}^{15}$ visa disponibilizar ao requerente uma forma mais célere de ter o seu direito de posse considerado e o consequente direito de propriedade tutelado.

\footnotetext{
${ }^{11}$ Ibidem.

${ }^{12}$ BRASIL. Lei $n^{\circ} 11.977$, de 7 de julho de 2009. Dispõe sobre o programa minha casa minha vida - PMCMV e a regularização fundiária de assentamentos localizados em áreas urbanas; altera o decreto-lei $n^{\circ} 3.365$, de 21 de junho de 1941, as leis $n^{\circ}$ s 4.380 , de 21 de agosto de 1964, 6.015, de 31 de dezembro de 1973, 8.036, de 11 de maio de 1990, e 10.257, de 10 de julho de 2001, e a medida provisória $n^{\circ} 2.197-43$, de 24 de agosto de 2001; e dá outras providências. Diário [da] República Federativa do Brasil. Brasília, 08 jul. 2009. Disponível em: $<$ htt ps://www.planalto.gov.br/ccivil_03/_ato2007-2010/2009/Lei/L11977.htm>. Acesso em: 22 out. de 2016.

${ }^{13}$ BRASIL. Constituição (1988). Constituição da República Federativa do Brasil. Brasília, DF, 5 out. 1988. Lex: legislação federal e marginalia. Disponível em: <http://www.planalto.gov.br/ccivil_03/Constituicao/Constituica o.htm>. Acesso em: 22 out. 2016

14 BRASIL, op. cit., 1973.

15 BRASIL, op. cit., 2015.
} 
Segundo Leonardo Brandelli, a demanda, que era sempre acolhida na via jurisdicional passou a poder ser extrajudicial;

[...] que pretendeu o legislador tornar a forma extrajudicial a regra em matéria de usucapião amigável, fomentando-a, na medida em que a disciplinou pormenorizadamente, com mais fôlego até do que a disciplina que existia no CPC de 1973, ao passo que deixou de tratar de maneira específica do procedimento de usucapião judicial, o qual, embora ainda sendo possível, e necessário em alguns casos, passou a estar englobado pelo procedimento processual comum. ${ }^{16}$

O usucapiente, optando pelo procedimento extrajudicial de usucapião, aviará pedido ao Oficial de Registro de Imóveis da circunscrição imobiliária na qual se encontra localizado o imóvel usucapiendo, o qual presidirá e conduzirá o processo, deferindo ou indeferindo o pedido de usucapião, embasado em lei. Nessa senda, o oficial irá presidir e decidir o processo administrativo comum da usucapião, por si ou seus prepostos autorizados, não havendo intervenção judicial e nem mesmo cota ministerial.

Como peça vestibular será aviado requerimento pela parte legitimada pleiteando a instauração do procedimento extrajudicial da usucapião, bem como o registro da usucapião ao final, justificando e comprovando o seu direito à usucapião, especificando qual a espécie de usucapião aplicável ao caso, relatando detalhadamente acerca do preenchimento dos requisitos materiais. No requerimento deverá vir consignado se há no caso concreto accessio possessionis, justo título, posse mansa, pacífica e ininterrupta pelo prazo necessário de acordo com a modalidade de usucapião invocada.

Nos termos do caput do art. 216-A da Lei $\mathrm{n}^{\circ} 6.015$ a parte legitimada deverá pleitear a usucapião extrajudicial representada por advogado, por meio de instrumento público ou particular de procuração, contendo poderes especiais e expressos, bem como o requerimento da parte interessada deverá estar instruído com os documentos constantes dos incisos I a IV do mesmo artigo. ${ }^{17}$

Em preliminar, a peça vestibular deverá vir acompanhada de ata notarial lavrada por Tabelião, atestando o tempo de posse do usucapiente ou de seus antecessores, em conformidade com a modalidade de usucapião. O Tabelião deverá narrar, com presunção relativa derivada de sua fé pública, os elementos que puder coletar a respeito da titularidade, do tempo e da qualidade da posse existente sobre o imóvel usucapiendo. Caso seja necessário, poderá

\footnotetext{
${ }^{16}$ BRANDELLI, op. cit., p. 70.

${ }^{17}$ BRASIL, op. cit., 1973.
} 
lavrar mais de uma ata notarial as quais deverão ser acostadas ao requerimento. O notário, na ata notarial, limitar-se-á a narrar, não the cabendo decidir a respeito. Caberá ao Oficial de Registro a decisão a respeito da procedência do pedido de usucapião, a análise das provas e o juízo de valor.

Acostado ao requerimento deverá vir planta e memorial descritivo contendo a descrição do imóvel usucapiendo, assinados por profissional legalmente habilitado pelo Conselho Regional de Engenharia e Agronomia (CREA) ou pelo Conselho de Arquitetura e Urbanismo (CAU), com Anotação de Responsabilidade Técnica (ART) quitada.

A planta e o memorial descritivo deverão indicar o imóvel usucapiendo e seus confrontantes mediante seus números de matrícula ou transcrição, declinando o CPF/MF do titular de direitos sobre o imóvel, facilitando a identificação dos mesmos pelo Oficial. Além do profissional habilitado, deverão assinar a planta e memorial descritivo concordando com o trabalho técnico e com o pedido aviado, o requerente, bem como todos os titulares de direitos, reais ou não, registrados ou averbados nas matrículas ou transcrições do imóvel usucapiendo e de seus confrontantes.

Além da Ata Notarial, planta, memorial descritivo, deverão ser apresentados juntamente com o requerimento, certidões negativas da comarca da situação do imóvel e do domicílio do requerente. Neste sentido entende-se que sejam necessárias certidões de distribuidores cíveis da justiça Estadual e da Justiça Federal, bem como a da comarca de situação do imóvel e do domicílio do usucapiendo. Em casos de acessio possessionis ou sucessio possessionis, as certidões devem constar em nome de todos os indivíduos que exerceram a posse no tempo necessário para usucapir.

Por derradeiro, o justo título poderá ser apresentado dependendo da modalidade de Usucapião, haja vista que o art. 1071, Inciso IV do Código de Processo Civil, orienta que o requerimento será instruído com “[...] justo título ou quaisquer outros documentos que demonstrem a origem, a continuidade, a natureza e o tempo da posse, tais como o pagamento de impostos e das taxas que incidirem sobre o imóvel" ${ }^{18}$. Nelson Rosenvald e Cristiano Chaves sintetizam o que vem a ser o instrumento:

\footnotetext{
${ }^{18}$ BRASIL, op. cit., 2015.
} 
Justo título é o instrumento que conduz um possuidor a iludir-se, por acreditar que ele lhe outorga a condição de proprietário. Trata-se de um título que, em tese, apresentase como instrumento formalmente idôneo a transferir a propriedade, malgrado apresente algum defeito que impeça a sua aquisição. Em outras palavras, é o ato translativo inapto a transferir a propriedade por padecer de um vício de natureza formal ou substancial. ${ }^{19}$

Além do justo título, o requerimento poderá ser instruído com quaisquer outros documentos que tenham a finalidade de demonstrar a origem, continuidade, natureza e o tempo da posse.

O pedido de usucapião feito extrajudicialmente deve ser inscrito no protocolo no Registro Imobiliário em cuja circunscrição territorial situa-se o imóvel. No momento da prenotação não há análise jurídica do pedido ou da documentação que o instrui, o que é feito em momento posterior, qual seja, o da qualificação registral, que é o momento onde há a cognição jurídica do pedido e dos documentos do processo.

Protocolado o pedido acompanhado dos documentos exigidos, será autuado o processo, tornando-se uma única peça documental, contendo termo de abertura, numeração e rubrica das folhas. A partir daí todas as intercorrências deverão ser certificadas no processo até final decisão, tais como: juntada de documento, eventual impugnação, diligência feita pelo oficial e publicação de editais.

O oficial deve receber as provas apresentadas a respeito da alegada ocorrência da aquisição do direito real imobiliário pela usucapião e analisar se são suficientes para formar sua convicção ou se necessita de mais provas, as quais deverá produzir ou solicitar que se produza. ${ }^{20}$

O oficial, ao analisar o arcabouço probatório, deverá entrar no mérito da questão, apreciando os aspectos formais, bem como verificar se houve a ocorrência dos requisitos materiais para a aquisição da propriedade por meio da usucapião.

Comprovada a aquisição do direito real imobiliário pela usucapião, sendo acolhido pelo oficial o pedido aviado pelo requerente, deverá ser efetivado um registro stricto sensu de usucapião, nos termos dos artigos 167, I e 28, da Lei de Registros Públicos. ${ }^{21}$

Ao final, após todas as diligências e uma apreciação minuciosa sobre o pedido, caso não reste comprovada a aquisição da propriedade pela usucapião, o Oficial do registro rejeitará o pedido.

\footnotetext{
${ }^{19}$ FARIAS, Cristiano Chaves de; ROSENVALD, Nelson. Direitos Reais. Rio de Janeiro: Lumen Juris, 2011. p. 342-343.

${ }^{20}$ BRANDELLI, op. cit., p. 103. ${ }^{21}$

BRASIL, op. cit., 1973.
} 
Existindo qualquer impugnação ao reconhecimento extrajudicial de usucapião apresentada por qualquer um dos titulares de direitos reais, por algum dos entes públicos ou por algum terceiro interessado, os autos serão remetidos ao juízo competente da comarca onde se encontre localizada o imóvel usucapiendo, cabendo ao requerente emendar a petição inicial, adequando ao procedimento comum. A rejeição do pedido extrajudicial não obstaculiza o pleito na via judicial.

\subsection{Evolução histórica da usucapião extrajudicial no direito brasileiro}

Com a edição da Medida Provisória $n^{\circ}$ 2.220/2001 entrou no cenário jurídico a possibilidade, pela via administrativa, da aquisição de direitos sobre imóveis públicos, mas a usucapião administrativa somente foi introduzida com o advento da Lei $n^{\circ} 11.977 / 2009$, posteriormente alterada pela Lei $\mathrm{n}^{\mathrm{o}} 12.424 / 2011$, refletindo um progresso na iniciativa do legislador brasileiro em promover a solução de conflitos fundiários.

A Lei $n^{0} 11.977 / 2009$ normatizou a regularização fundiária e trouxe em seu bojo procedimentos a fim de regularizar assentamentos irregulares alocados em áreas urbanas, que se encontravam de forma consolidada. Nas duas hipóteses de regularização fundiária trazidas pela Lei $\mathrm{n}^{\mathrm{o}} 11.977 / 2009$, por interesse social ou específico, a lei estabeleceu institutos privilegiados e facilitadores para a regularização de interesse social. Brandelli ressalta, entretanto, que a aquisição da propriedade só se dava nos casos de interesse social e com o prévio registro do título de legitimação de posse, disponibilizado pelo poder público. ${ }^{21}$

Com o advento do novo Código de Processo Civil, que introduziu o art. 216-A na Lei $n^{\circ} 6.015 / 1973$, possibilitou-se a total execução da usucapião extrajudicial, nas hipóteses que não houver litígio, reconhecendo a aquisição do direito imobiliário.

\footnotetext{
${ }^{21}$ BRANDELLI, Leonardo. Usucapião Administrativa de acordo com o novo Código de Processo Civil. São Paulo: Saraiva, 2016. p.21.
} 
O processo da usucapião extrajudicial é processo de natureza administrativa, e não jurisdicional. ${ }^{22}$ Entretanto, por se tratar de processo administrativo, a revisão judicial será sempre admitida, podendo ser levada para apreciação do Poder Judiciário a qualquer tempo, por força do art.37, XXXV da CR/1988.

Pela mesma razão, por ser do regime jurídico da jurisdição a litispendência e a coisa julgada, conforme preceitua os artigos 301, IX e 502 a 508 do novo CPC, sendo a usucapião extrajudicial um procedimento administrativo, a ela não se aplicam o mesmo regime.

Além disso, no processo extrajudicial da usucapião, o oficial de registro de imóveis, na qualidade de autoridade administrativa, examinará minuciosamente as provas, deferindo ou rejeitando o pedido ao final do processamento. Todavia, o registrador de imóveis restringir-seá a questões administrativas, abstendo-se de apreciar questões jurídicas próprias da esfera judicial, conforme leciona Leonardo Brandelli ao afirmar que:

Como procedimento administrativo que é, deve o Oficial de Registro ater-se a lei na sua condução, decidindo as questões procedimentais e de mérito pertinente, mas não tendo atribuição para analisar questões jurídicas que ultrapassem a possibilidade de um processo administrativo, tal como a alegação de inconstitucionalidade do instituto, ou a necessidade de alguma medida de tutela provisória nos termos do art. 294 e seguintes do NCPC. ${ }^{23}$

Saliente-se que, mesmo o reconhecimento da usucapião ter sido alcançada pela forma administrativa, a aquisição continua sendo originária.

\section{Semelhanças e diferenças entre o procedimento judicial e extrajudicial da usucapião}

Ao pleitear reconhecimento do domínio imobiliário por meio do instituto da usucapião via judicial ou extrajudicial, o usucapiente deverá comprovar os requisitos objetivos e subjetivos basilares ao instituto e satisfazer a muitas exigências de caráter formal e processual, requisitos indispensáveis ao pedido, guardada a adequação para cada espécie de usucapião.

\footnotetext{
${ }^{22}$ BRANDELLI, Leonardo. Usucapião Administrativa de acordo com o novo Código de Processo Civil. São Paulo: Saraiva, 2016. p.22.

${ }^{23}$ BRANDELLI, Leonardo. Usucapião Administrativa de acordo com o novo Código de Processo Civil. São Paulo: Saraiva, 2016. p.23.
} 
Atualmente o novo CPC não prevê procedimento especial para a ação de usucapião, embora se refira a ela em seus artigos 246 e 259. Com isso essa ação foi inserida dentre as ações de procedimento comum. Contudo, independente da forma como a usucapião for requerida, seja judicial ou extrajudicial, a assessoria de um profissional do direito continua sendo imprescindível por força de lei, o que assegurará boa defesa do interesse dos jurisdicionados.

No procedimento judicial da usucapião é apresentada juntamente com a peça vestibular, uma planta georreferenciada, elaborada por engenheiro inscrito no CREA ou CAU; com ART, devidamente quitada; cópias da planta e memorial descritivo para citação das partes necessárias no processo e certidão expedida pelos cartórios de registro de imóveis referente ao imóvel usucapiendo.

Além das citações dos titulares de direitos reais sobre o imóvel e confinantes, cientificação do Município, Estado ou Distrito Federal e União, da oitiva das testemunhas, expedição de edital a terceiros eventualmente interessados e documentos comprobatórios do alegado, o requerente deverá provar todos os requisitos imprescindíveis da Ação de Usucapião, que serão apreciados pelo Juiz que, após vista ao Ministério Público, esta facultativa, acolherá ou não o pedido da aquisição da propriedade por meio do instituto da usucapião. Frise-se que no procedimento judicial será nomeado curador ao ausente citado por edital.

A prolação da sentença, com seu trânsito em julgado, faz surgir o efeito da coisa julgada material, trazendo assim, estabilidade, certeza e segurança jurídica para a situação de fato, eliminando toda e qualquer dúvida sobre o domínio do bem.

A decisão que declara o domínio, direito preexistente, é documento hábil a ser registrado no cartório de registro de imóveis da circunscrição onde se encontra o imóvel usucapiendo e seus efeitos retroagem à propositura da ação. Registrar a sentença de usucapião opera diversos efeitos práticos: a) transmissibilidade do domínio a terceiros, bem como disposição do bem de outras formas; b) publiciza o ato; c) acrescenta o bem usucapido ao patrimônio do usucapiente; d) agrega valor econômico a propriedade pela existência do título.

A decisão declaratória da usucapião possui eficácia erga omnes, isto é, oponível contra todos, não fazendo coisa julgada só entre as partes, nos termos da lei processual. Para Fábio Caldas de Araújo, na sentença de Usucapião a eficácia direta e indireta é erga omnes, ou seja, atinge a todos. A autoridade da coisa julgada vale de modo integral, o que se revela uma condição essencial para o respeito do direito de propriedade que se forma com a nova matrícula que será registrada. ${ }^{24}$

\footnotetext{
${ }^{24}$ ARAÚJO, Fábio Caldas de. O Usucapião no Âmbito Material e Processual. 1. ed. Rio de Janeiro: Forense,
} 2005. 
No procedimento extrajudicial de usucapião, constante do art. 216-A da Lei $n^{0}$ 6.015/1973 e normatizado pelo Conselho Nacional de Justiça, pelo Provimento n. ${ }^{\circ}$ 65, de 14 de dezembro de 2017, o pedido do reconhecimento da usucapião é feito perante ao Cartório de Registro de Imóveis da comarca onde se encontra localizado o imóvel usucapiendo, por requerimento do prescribente, ou por mais de um, se for o caso, atendendo no que couber, aos requisitos da petição inicial.

Junto ao requerimento vem a Ata Notarial atestando o tempo e as características da posse do requerente e seus antecessores, a forma de aquisição, a modalidade da usucapião pretendida e sua base legal ou constitucional, o valor do imóvel, bem como a apresentação de documentos, oitivas do requerente e testemunhas e ainda, em anexo, planta e memorial descritivo, devidamente assinados por profissão legalmente habilitado, com prova de anotação de responsabilidade técnica e pelos titulares de direitos reais e confinantes.

O requerimento poderá ser instruído com mais de uma ata notarial, por ata notarial complementar ou por escritura declaratória. Saliente-se que a ata notarial será lavrada pelo tabelião de notas do munícipio em que estiver localizado o imóvel usucapiendo ou a maior parte dele. Este, bem como os documentos que o compõe é protocolado pelo Oficial de Registro, que autuará o processo, rubricando todas as folhas, fazendo, em preliminar, apreciação do feito.

O Oficial deverá receber as provas apresentadas a respeito da alegada ocorrência da aquisição do direito real imobiliário pela usucapião e analisar se há provas suficientes para formar sua convicção ou se necessita de mais provas, as quais deverá produzir ou solicitar que se produza. Caso haja pendência de anuência de algum dos titulares de direito e confrontantes, far-se-á a notificação do mesmo, pessoalmente ou pelos Correios com aviso de recebimento, ou ainda, se preferir o oficial de registro, encaminhará ao Cartório de Títulos e Documentos da comarca para fazê-la, a fim de que o não anuente se manifeste o seu consentimento expresso em 15(quinze) dias, interpretado o seu silêncio como concordância. ${ }^{25}$ A notificação deverá ser acompanhada de cópia do requerimento vestibular e ata notarial, bem como de cópia de planta e do memorial descritivo e demais documentos que a instruíram. Na hipótese do notificando não for encontrado ou estiver em lugar incerto ou não sabido ou inacessível, será procedido sua notificação por edital, nos moldes do $§ 13$, do artigo 216-A, da Lei nº 6015/1973, c/c o que determina o Provimento n. ${ }^{\circ}$ 65, de 14 de dezembro de 2017, expedido pelo CNJ, devendo o edital ser publicado por duas vezes, em jornal local de grande circulação, pelo prazo de quinze

\footnotetext{
${ }^{25}$ BRASIL, op. cit., 1973.
} 
dias cada um. Não há neste procedimento a nomeação de curador ao ausente citado por edital, como acontece procedimentalmente na via judicial.

A normatização do procedimento extrajudicial feita pelo CNJ no Provimento $n^{\circ} 65$, de 14 de dezembro de 2017 , trouxe uma grande novidade no $\S 10$ do art. 10 , no que concerne à dispensa da notificação dos confrontantes do imóvel, quando este for matriculado e conter descrição precisa e perfeita identidade entre a descrição tabular e a área usucapienda. Somandose a esta inovação, o art. 13 do mesmo dispositivo normalizador, dispensa a notificação quando for apresentado pelo requerente justo título ou instrumento que demonstre a existência de relação jurídica com titular registral, desde que justificado o óbice à correta escrituração das transações para evitar o uso da usucapião como meio de burla dos requisitos legais e da tributação dos impostos de transmissão incidentes sobre os negócios jurídicos.

Ao final, havendo provas suficientes ou não, porque não são possíveis de produzir, ou porque a parte interessada não as produziu apesar de solicitadas e possíveis, deverá o Oficial de Registro decidir, positiva ou negativamente o pedido feito. ${ }^{26}$

Em caso de impugnação do pedido de reconhecimento extrajudicial da usucapião por qualquer parte interessada no feito, o oficial tentará promover a conciliação ou mediação entre os conflitantes, não havendo composição, persistindo a impugnação, o oficial de registro lavrará relatório circunstanciado de todo o processamento da usucapião, entregando os autos do pedido da usucapião ao requerente. Caso for de sua vontade, o requerente poderá emendar a peça vestibular, de modo a seguir pelo procedimento comum, ou ainda se quiser, requerer suscitação de dúvida. O procedimento extrajudicial não comporta a discussão de litígios.

Como bem salientado por Brandelli, é tarefa árdua e complexa do Oficial de Registro de Imóveis fazer análise dos requisitos ensejadores da aquisição pela usucapião, posto que neste procedimento administrativo não há o contraditório processual com a mesma extensão que há no âmbito judicial. No procedimento extrajudicial da usucapião não há proteção da coisa julgada $^{27}$.

Restando provada a aquisição do direito real imobiliário pela usucapião, o Oficial prolatará decisão e posteriormente praticará o registro stricto sensu de usucapião, nos termos dos arts. 167, I e 28, da Lei $n^{\circ} 6.015 / 1973$. A aquisição se dá de forma originária, como se tivesse sido declarada judicialmente. Frise-se, ainda, que no procedimento extrajudicial não há intervenção do Ministério Público.

\footnotetext{
${ }^{26}$ BRANDELLI, op. cit., p. 103.

${ }^{27}$ Ibidem, p. 105.
} 


\section{A usucapião extrajudicial e a segurança jurídica}

Humberto Ávila conceitua segurança jurídica como sendo “[...] um valor ético que antecede ao Estado e que este incorpora para gerar certeza, confiabilidade e estabilidade às relações sociais regidas pelo direito". ${ }^{28}$ Segurança é a qualidade daquilo que se pode ter certeza, convicção, ou ainda confiança. ${ }^{29}$

O direito, como instrumento de organização da vida em sociedade, surge para assegurar a segurança, que constitui fundamento do mesmo, nas relações entre os indivíduos e destes com o Estado. Assim, para se qualificar um ordenamento jurídico de acordo com o sistema de direitos fundamentais e com o Estado Democrático de Direito a segurança jurídica é requisito necessário. ${ }^{30}$

O princípio da segurança jurídica é elemento essencial ${ }^{31}$ e constitutivo do Estado de direito. ${ }^{32}$ Kelsen afirma que o Estado de Direito não existe sem segurança jurídica, pois este é o princípio daquele. ${ }^{34}$ Também na jurisprudência do STF a segurança jurídica aparece como elemento inerente ao Estado de Direito. ${ }^{33}$

A primeira segurança que emana do sistema jurídico é, pois, a própria segurança jurídica contra o Estado, principalmente ao se considerar que um estado de direito produz o direito e a ele também se submete. ${ }^{34}$ Portanto, não basta a existência de um Estado ou mesmo

\footnotetext{
${ }^{28}$ ÁVILA, op. cit., p. 62.

${ }^{29}$ PAULSEN, Leandro. Segurança jurídica, certeza do direito e tributação: a concretização da certeza quanto à instituição de tributos através das garantias da legalidade, da irretroatividade e da anterioridade. Porto Alegre: Livraria do Advogado, 2006, p. 165.

${ }^{30}$ NASSAR, Elody. Prescrição na Administração Pública. 2. ed. São Paulo: Saraiva, 2009, p. 38.

31 CAnotilho, J. J. Gomes. Direito Constitucional e Teoria da Constituição. 7. ed. Coimbra: Livraria Almedina, 2003, p. 264.

${ }^{32} \mathrm{O}$ princípio da segurança jurídica é construído de duas formas. Em primeiro lugar, pela interpretação dedutiva do princípio maior do Estado de Direito (art. $1^{\circ}$ ). ÁVILA, Humberto. Sistema constitucional tributário, 2004. p. 295; STRECK, Lenio Luiz. Ciência política e teoria geral do Estado. 8. ed. São Paulo: Saraiva, 2013, p. $90 .{ }^{34}$ O princípio que se traduz em vincular a decisão dos casos concretos a normas gerais, que hão de ser criadas de antemão por um órgão legislativo central, também pode ser estendida, por modo consequente, à função dos órgãos administrativos. Ele traduz, neste seu aspecto geral, o princípio do Estado-de-Direito que, no essencial, é o princípio da segurança jurídica. KELSEN, Hans. Teoria pura do direito. Trad. João Baptista Machado. 6. ed. São Paulo: Martins Fontes, 1998. p. 279.

${ }^{33}$ Pois bem, considerando o status constitucional do direto à segurança jurídica (art. $5^{\circ}$, caput), proteção objetiva do princípio da dignidade da pessoa humana (inciso III do art. $1^{\circ}$ ) e elemento conceitual do Estado de Direito [...]. voto do Min. Carlos Brito, no MS 25.116/DF, publicado na seção Transcrições do Informativo STF 471.

${ }^{34}$ Com a submissão do poder político à lei e, posteriormente, à Constituição, de modo a garantir o seu exercício sem arbítrio, em conformidade com a vontade popular, como instrumento e em benefício da sociedade, tem-se a extensão desta ideia de segurança jurídica também às relações com o Estado, traduzida na ideia de Estado de Direito, nas suas diversas concepções, ou na noção de supremacia do Direito. PAULSEN, op. cit., p.33. ${ }^{37}$ GUSSI,
} 
do direito, é preciso existir Estado de Direito para existir segurança jurídica, pois inexistindo segurança jurídica não há segurança alguma.

A segurança jurídica exprime o ajuste entre a função ordenadora do direito (imperativo social) e a missão concretizadora da justiça (anseio individual) desejável por todos que se submetem à ciência jurídica. Ao se ordenar, na busca de uma coexistência pacífica e mais harmoniosa, o direito deve estabelecer critérios e fazer opções; institutos são criados, limitações legais passam a existir e alguns interesses jurídicos podem preponderar sobre outros.

Conforme leciona Evandro Gussi, a segurança é "[...] o estabelecimento da justiça no tempo", ${ }^{37}$ pois não há justiça num ambiente inseguro. Sem segurança jurídica não há bem comum nem justiça. ${ }^{35}$

Canotilho ensaia a conceituação do que ele denomina "princípio geral de segurança jurídica", em seu sentido mais amplo, e que compreende também a ideia de "proteção da confiança". Para o conceituado constitucionalista, esse princípio geral pode ser assim entendido:

Os indivíduos têm o direito de poder contar com o fato de que aos seus atos ou às decisões públicas concernentes a seus direitos, posições ou relações jurídicas fundadas sobre normas jurídicas válidas e em vigor, se vinculem os efeitos previstos e assinados por estas mesmas normas. ${ }^{36}$

Canotilho finaliza sua conceituação sublinhando que o "princípio de segurança jurídica exige a confiabilidade, a clareza, a razoabilidade e a transparência dos atos do poder”, para, em seguida, revelar as mais importantes manifestações deste princípio. Para o autor:

(1) Relativamente a atos normativos - proibição de normas retroativas restritivas de direitos ou interesses juridicamente protegidos; (2) relativamente a atos jurisdicionais - inalterabilidade do caso julgado; (3) em relação a atos da administração - tendencial estabilidade dos casos decididos por meio de atos administrativos constitutivos de direitos. $^{40}$

Não esculpido expressamente no texto constitucional brasileiro, a segurança jurídica se apresenta como princípio constitucional implícito, sendo construído pelos conceitos de Estado de Direito, de direitos fundamentais individuais e sociais, do princípio da legalidade, da proteção do direito adquirido, do ato jurídico perfeito e da coisa julgada e das garantias da irretroatividade e anterioridade fiscal.

Evandro Herrera Bertone. A segurança na Constituição. Dissertação (Mestrado em Direito). Porto Alegre: Universidade Federal do Rio Grande do Sul, 2005.

35 PAUPERIO, Arthur Machado. Segurança jurídica: verbete in Enciclopédia Saraiva do Direito. v. 67. Coordenação Limongi França. São Paulo: Saraiva, 1977, p. 292.

${ }^{36}$ CANOTILHO, op. cit., p. $250 .{ }^{40}$

Ibidem, p. 250. 
O fundamento principal do instituto da usucapião é conferir segurança jurídica a uma situação que se consolidou com o decurso do tempo e que poderá transformar-se no robusto e desejado direito de propriedade.

No direito brasileiro a usucapião sempre havia sido judicial, e de tal maneira que esse procedimento é uma tradição jurídica, de forma que a reformulação legislativa pode soar estranha à primeira vista, muito mais pela conformidade com a forma que sempre existiu, do que por ilegalidade ou inconstitucionalidade. ${ }^{37}$

Em casos não litigiosos é recomendável que a questio iuris não seja submetida ao Poder Judiciário e sim perante ao Cartório de Registro de Imóveis competente, que conduzirá o processo da usucapião administrativamente, permitindo ao juiz se dedicar a outras questões litigiosas que lhes são submetidas. A questão será resolvida por outro profissional do Direito um delegatário do Estado - que, agindo com fé pública, independência e imparcialidade, dará solução rápida ao procedimento, velando sempre pela tão almejada segurança jurídica.

Sabe-se que, por se tratar de processo administrativo, a revisão jurisdicional será sempre possível, podendo ser levada para apreciação do poder judiciário a qualquer tempo. Pela mesma razão, a usucapião extrajudicial não induza a litispendência ou faça coisa julgada, que são qualidades da jurisdição, conforme artigos 301, IX e 502 a 508, do novo CPC.

O fato do procedimento e consequente registro da usucapião extrajudicial serem questionados judicialmente não lhe tira os efeitos da segurança jurídica, pois até mesmo no procedimento judicial da usucapião pode sofrer revisão do próprio judiciário por meio de ação rescisória, comprovado um dos vícios previstos no rol taxativo do art. 966 do CPC.

No procedimento extrajudicial da usucapião se constatar algum vício que leve à nulidade ou anulabilidade, se o interessado exercer posse com boa-fé, prazo suficiente para qualquer modalidade de usucapião, haverá a convalidação do ato viciado, que permanecerá ileso a qualquer ação que busque seu desfazimento, pautado na segurança jurídica.

O próprio registro da usucapião extrajudicial faz nascer a presunção da boa-fé para o titular registral, de modo que ela será presumida. Quem impugnar o ato registral atrairá o ônus de provar não só a sua irregularidade como também de quebrar a presunção de boa-fé que contamina o titular do direito real inscrito. ${ }^{38}$

Caso haja alguma ação judicial questionando o ato registral, pode-se utilizar o art. 214, $\S 5^{\circ}$, da Lei $n^{\circ} 6.015 / 1973$ - também conhecido como Usucapião Tabular - como defesa,

\footnotetext{
${ }^{37}$ BRANDELLI, op. cit., p. 15.

${ }^{38}$ Apesar de presumida a boa-fé, pode ser provada a má-fé diante de uma análise da conduta do adquirente. Ibidem, p. 81 .
} 
neutralizando a pretensão inicial de desfazimento de ato já consolidado pela posse de quem titularizava o direito inscrito, trazendo como consequência o aumento da legitimidade do próprio ordenamento jurídico e uma maior eficácia de suas disposições.

Para San Tiago Dantas “[...] o fundamento da usucapião não é outro senão garantir a estabilidade e segurança da propriedade, fixando um prazo, além do que não se podem mais levantar dúvidas ou contestações a seu respeito. ${ }^{39}$

Cristiano Chaves de Farias e Nelson Rosenvald afirmam que a intransigência do artigo 169 do Código Civil, de que a nulidade nunca convalesce, é relativizada em razão da "[...] ponderação com outros princípios, como o da confiança, aparência e a preservação da segurança jurídica". 40

Portanto, sempre que houver um direito inscrito e posse pelo seu titular, por prazo suficiente para configurar algum tipo de usucapião, esse direito, ainda que eivado de nulidade, poderá ser confirmado, sendo cabível o processamento extrajudicial de pedido de usucapião para estabilizar a situação jurídica registral.

Por fim, o que se quer é um sistema de registros públicos que promova a segurança jurídica e a certeza, predicados de inestimável valia ao desenvolvimento econômico e social.

\section{Considerações finais}

Ao analisar com mais veemência os procedimentos de reconhecimento judicial e extrajudicial da usucapião, percebeu-se que o procedimento desjudicializado da usucapião é, sem dúvida, uma das grandes novidades do novo Código de Processo Civil.

Apesar do instituto da usucapião extrajudicial ser uma inovação, a Lei n ${ }^{0}$ 11.977/2009, que normatizou a usucapião administrativa, já trazia no seu bojo a desjudicialização, entretanto limitando-se, tão somente, a casos de regularização fundiária urbana. Anteriormente à Lei $\mathrm{n}^{\mathrm{o}}$ 11.977/2009, já havia a edição da Medida Provisória nº 2.220/2001, que regularizou, pela forma administrativa, a aquisição de direitos sobre áreas públicas pela prescrição aquisitiva.

O Novo Código de Processo Civil introduziu por meio do art. 216-A na Lei de Registros Públicos o procedimento da usucapião extrajudicial, visando a solução do feito fora

\footnotetext{
${ }^{39}$ DANTAS, Francisco Clementino San Tiago. Programa de direito civil III: Direito das Coisas. Rio de Janeiro: Editora Rio. 1979, p. 161.

${ }^{40}$ FARIAS, Cristiano Chaves de; ROSENVALD, Nelson. Curso de Direito Civil. v. 5. Salvador: Juspodivm, 2014, p. 373.
} 
do judiciário e junto ao cartório de registro de imóveis, na situação em que não haja litígio, prezando pela celeridade.

O processo da usucapião extrajudicial tem natureza administrativa e, portanto, a revisão judicial será sempre admitida, podendo ser levada para apreciação do poder judiciário a qualquer tempo. Pela mesma razão, por serem qualidades da jurisdição a litispendência e coisa julgada, sendo a usucapião extrajudicial um procedimento administrativo, o mesmo não é abarcado com estas qualidades. Saliente-se que, mesmo o reconhecimento da usucapião ter sido alcançada pela forma administrativa, a aquisição continua sendo originária, como se tivesse sido declarada judicialmente. Portanto, restou-se questionar:

O procedimento extrajudicial da usucapião oferece a mesma segurança jurídica que o procedimento judicial de usucapião?

Ao analisar o procedimento instituído pelo novo Código de Processo Civil em comparação com o procedimento judicial existente, não pairam dúvidas que este novo procedimento oportunizou maior efetividade e celeridade na execução deste instituto, trazendo, por consequência, benefícios aos usuários, no tocante à estabilidade da propriedade imobiliária. Contudo, a presente investigação foi realizada com o objetivo de apurar se o procedimento desjudicializado da usucapião gera segurança jurídica em face do procedimento judicial.

Primeiramente, há que se considerar que não há óbice constitucional em levar para outro órgão, que não o judicial, o reconhecimento da usucapião, desde que não exclua a possibilidade da discussão judicial.

O procedimento extrajudicial será conduzido pelo oficial de registro de imóveis, que, dentre todos os profissionais do direito, aquele a quem a usucapião não litigiosa de bens imóveis é mais afetada pela própria natureza jurídica da função registral imobiliária, cabendo de modo eficiente fazer a depuração jurídica de tais direitos, qualificando-os juridicamente, com intuito de publicizá-los, com efeito declarativo.

O fato do processo da usucapião extrajudicial que culminou o registro ser questionado judicialmente, a qualquer tempo, não lhe retira a segurança jurídica, haja vista que até no procedimento judicial, dentro do prazo prescricional, o mesmo pode sofrer ação rescisória. Ademais, caso seja alegado em juízo alguma nulidade ou anulabilidade na condução do processo da usucapião extrajudicial, o usucapiente, em matéria de defesa, poderá valer-se do art. $214, \S 5^{\circ}$, da Lei $\mathrm{n}^{\mathrm{o}} 6.015 / 1973$, doutrinariamente conhecido como usucapião tabular, provando posse de boa-fé e prazo suficiente para qualquer modalidade de usucapião, convalidando o ato viciado, prevalecendo a presunção da boa-fé e os efeitos da segurança jurídica. 
Ressalte-se ao final, que a intransigência do artigo 169 do Código Civil, de que a nulidade nunca convalesce, deve ser relativizada com a aplicação da ponderação com outros princípios, como o da confiança, aparência e a preservação da segurança jurídica ao usuário.

\section{Referências bibliográficas}

ARAÚJO, Fábio Caldas de. O Usucapião no Âmbito Material e Processual. 1. ed. Rio de Janeiro: Forense, 2005.

ÁVILA, Humberto. Sistema constitucional tributário, 2004. p. 295.

ÁVILA, Humberto. Teoria dos princípios. Da definição à aplicação dos princípios jurídicos. 6. ed. São Paulo: Malheiros, 2006. p. 62.

BRANDELLI, Leonardo. Usucapião Administrativa de acordo com o novo Código de Processo Civil. São Paulo: Saraiva, 2016.

BRASIL. Constituição (1988). Constituição da República Federativa do Brasil. Brasília, DF, 5 out. 1988. Lex: legislação federal e marginalia. Disponível em: $<$ http://www.planalto.gov.b r/ccivil_03/Constituicao/Constituica o.htm>. Acesso em: 22 jul. 2018.

BRASIL. Lei $n^{\circ}$ 6.015, de 31 de setembro de 1973. Dispõe sobre os registros públicos e dá outras providências. Diário [da] República Federativa do Brasil. Brasília, 16 set. 1975. Disponível em: <https://www.planalto .gov.br/ccivil_03/_ato20152018/2015/lei/113105.htm>. Acesso em: 22 jul. 2018.

BRASIL. Lei n ${ }^{\circ} 11.977$, de 7 de julho de 2009. Dispõe sobre o programa minha casa minha vida - PMCMV e a regularização fundiária de assentamentos localizados em áreas urbanas; altera o decreto-lei $n^{\circ} 3.365$, de 21 de junho de 1941, as leis $n^{\circ} \mathrm{s} 4.380$, de 21 de agosto de 1964, 6.015, de 31 de dezembro de 1973, 8.036, de 11 de maio de 1990, e 10.257, de 10 de julho de 2001, e a medida provisória n $2.197-43$, de 24 de agosto de 2001; e dá outras providências. Diário [da] República Federativa do Brasil. Brasília, 08 jul. 2009. Disponível em: <htt ps://www.planalto.gov.br/ccivil_03/_ato2007-2010/2009/Lei/L11977.htm>. Acesso em: 22 jul. de 2018. 
BRASIL. Lei n ${ }^{0} 13.105$, de 16 de março de 2015. Código de Processo Civil. Diário [da] República Federativa do Brasil. Brasília, 17 de mar. 2015. Disponível em: <https://www. planalto.gov.br/ccivil_03/_a to20152018/201 5/lei/113105.htm>. Acesso em: 22 jul. de 2018.

CANOTILHO, J. J. Gomes. Direito Constitucional e Teoria da Constituição. 7. ed. Coimbra: Livraria Almedina, 2003.

DANTAS, Francisco Clementino San Tiago. Programa de direito civil III: Direito das Coisas. Rio de Janeiro: Editora Rio. 1979.

FARIAS, Cristiano Chaves de; ROSENVALD, Nelson. Curso de Direito Civil. v. 5. Salvador: Juspodivm, 2014.

FARIAS, Cristiano Chaves de; ROSENVALD, Nelson. Direitos Reais. Rio de Janeiro: Lumen Juris, 2011.

GUSSI, Evandro Herrera Bertone. A segurança na Constituição. Dissertação (Mestrado em Direito). Porto Alegre: Universidade Federal do Rio Grande do Sul, 2005.

KELSEN, Hans. Teoria pura do direito. Trad. João Baptista Machado. 6. ed. São Paulo: Martins Fontes, 1998.

NASSAR, Elody. Prescrição na Administração Pública. 2. ed. São Paulo: Saraiva, 2009, p. 38.

PAULSEN, Leandro. Segurança jurídica, certeza do direito e tributação: a concretização da certeza quanto à instituição de tributos através das garantias da legalidade, da irretroatividade e da anterioridade. Porto Alegre: Livraria do Advogado, 2006, p. 165.

PAUPERIO, Arthur Machado. Segurança jurídica: verbete in Enciclopédia Saraiva do Direito. v. 67. Coordenação Limongi França. São Paulo: Saraiva, 1977. 
PINHEIRO, Fábio Monteiro. Usucapião de bens imóveis. Revista Eletrônica Direito, Justiça e Cidadania. v. 2, n. 1, 2011.

SALLES, José Carlos de Moraes. Usucapião de bens imóveis e móveis. 6. ed. Rio de Janeiro: Revista dos Tribunais, 2006.

STRECK, Lenio Luiz. Ciência política e teoria geral do Estado. 8. ed. São Paulo: Saraiva, 2013.

WAMBIER, Luiz Rodrigues; TALAMINI, Eduardo. Curso avançado de processo civil. 14. ed. v. 3. São Paulo: Revista dos Tribunais, 2015. 


\title{
APLICABILIDADE DA TUTELA ANTECIPADA OU CAUTELAR (LIMINARES) NO DIREITO DE FAMÍLIA: INSTRUMENTOS PARA A SOLUÇÃO DOS CONFLITOS FAMILIARES
}

\author{
Eudes Vitor Bezerra \\ Uninove \\ Marcelo Negri Soares \\ UniCesumar
}

\begin{abstract}
Resumo
O presente artigo aborda a aplicabilidade da tutela antecipada e/ou cautelar (liminares) no direito de família, instrumentos necessários para a solução dos conflitos familiares. As problemáticas, no âmbito do Direito de Família, exigem formas eficientes que viabilizem celeridade, sob pena de perecimento do direito. Com base no método hipotético-dedutivo, com aporte na doutrina especialidade e legislação vigente, o ensaio tem o escopo de analisar como o Código de Processo Civil pode viabilizar efetividade/celeridade nas questões envoltas ao Direito de Família e se os mecanismos processuais são capazes de estabelece a celeridade processual.
\end{abstract}

Palavras-chave: Direito de família, Tutela de urgência, Novo Código de Processo Civil, Solução de conflitos familiares.

\begin{abstract}
Resumen/Résumé
This article deals with the applicability of early and / or precautionary guardianship (liminaries) in family law, instruments necessary for the resolution of family conflicts. The problems, within the scope of Family Law, require efficient forms that enable speed, under penalty of perjury of law. On the basis of the hypothetical-deductive method, with contribution in the specialty doctrine and current legislation, the essay has the scope to analyze how the Code of Civil Procedure can make effectiveness / celerity feasible in the questions related to the Family Law and if the procedural mechanisms are capable of establishing procedural celerity.
\end{abstract}

Keywords/Palabras-claves/Mots-clés: Family right, Emergency care, New Code of Civil Procedure, Solving family conflicts. 


\section{Introdução}

Ao analisar as relações humanas, é fato de que há uma necessidade de positivação para que exista uma ordem e disciplina comportamental, com essa finalidade, o Direito de Família foi criado para regulamentar os vínculos familiares, evitando a desordem decorrente ao envolvimento de valores de extremo sentimentalismo nesta esfera.

Cabendo afirmar que o cunho material da solução dos conflitos destas relações são resolvidas por via processual, de forma tempestiva e apropriada para cada caso. Assim, a forma de solução dinâmica e eficaz é feita por intermédio de tutelas cautelares, remédios processuais céleres e eficientes para os litígios familiares de qualquer natureza.

A aplicabilidade da tutela cautelar se faz como uma forma de prevenção de possível dano ao direito que necessita de imediata proteção diante de determinada ameaça de caráter repentino. Sendo divididas em diversas modalidades pelo Novo Código de Processo Civil NCPC.

Sob uma análise mais abrangente, podemos afirmar que o Direito de Família possui a função de proteção dos direitos fundamentais relativos à dignidade da pessoa humana, com normas de caráter repressivos e preventivos, com a finalidade de suavizar conflitos decorrentes nas relações do liame familiar, pessoal e patrimonial.

É de extrema relevância que o Poder Judiciário permaneça sempre atuante como ente fiscalizador e protetor dos direitos de família, tendo em vista que qualquer sociedade é estruturada e tem como base para formação do Estado uma família saudável e sem conflitos. Já que os danos causados pela não resolução de litígios entre familiares pode resultar em graves danos irreversíveis à sociedade.

Assim, com base no método hipotético-dedutivo, com aporte na doutrina especialidade e na legislação vigente, o ensaio em tela tem o escopo de analisar como o NCPC pode viabilizar efetividade/celeridade nas questões envoltas ao Direito de Família, bem como se os mecanismos processuais são capazes de estabelece a celeridade processual.

Para tanto, no primeiro capítulo explanaremos, de forma sintética, a antecipação da tutela, passando pela tutela jurisdicional, após pela tutela provisória, tutela de urgência e, ainda, pela tutela de evidência.

No segundo e último capítulo, será demonstrado como a tutela antecipada e/ou cautelar (liminares) no direito de família são aplicadas, em especial, no que tange a utilização do NCPC para resguardar tais direitos. 
A partir de tal cenário serão destacados de forma breve, os pontos mais importantes do exercício da aplicabilidade do NCPC no Direito de Família, para contribuição de melhoria na interpretação e entendimento do novo diploma legal.

\section{Tutela Jurisdicional}

Antes de adentramos ao foco do presente ensaio, ou seja, analisarmos as tutelas provisórias, necessário tecermos alguns comentários sobre a Tutela Jurisdicional.

Desse modo, importa lembrar que nos primórdios da humanidade, os homens resolviam seus conflitos pela força e/ou pela violência, onde o mais forte levava vantagens sobre o mais fraco. Tínhamos, pois, a autotutela, que é defeso ao cidadão exercê-lo, atualmente. Com o passar do tempo, o Estado sentiu a necessidade de albergar para si a solução dos conflitos de interesses como forma de buscar o bem comum e a paz social.

Surge, assim, a tutela jurisdicional, realizada quando o Estado-Juiz e provocado a prestar a jurisdição, sendo certo que a resposta a essa provação ocorre via processo, instrumento pelo qual o Estado-Juiz desempenha a jurisdição.

Corroborando tal entendimento, Luiz Fux1 aduz que o Estado chamou para si a responsabilidade em por cabo aos conflitos de interesse, via a aplicação do direito pelo Poder Judiciário, vejamos:

O Estado, como garantidor da paz social, avocou para si a solução monopolizada dos conflitos intersubjetivos pela transgressão à ordem jurídica, limitando o âmbito da autotutela. Em consequência, dotou um de seus Poderes, o Judiciário, da atribuição de solucionar os referidos conflitos mediante a aplicação do direito objetivo, abstratamente concebido, ao caso concreto. A supremacia dessa solução revelou-se pelo fato incontestável de a mesma provir da autoridade estatal, cuja palavra, além de coativa, torna-se a última manifestação do Estado soberano acerca da contenda, de tal sorte que os jurisdicionados devem-na respeito absoluto, porque haurida de um trabalho de reconstituição dos antecedentes do litígio, com a participação dos interessados, cercados, isonomicamente, das mais comezinhas garantias. (FUX, 2002. P. 1)

Assim, sendo, podemos afiançar que todo aquele que buscar o poder judiciário tem o direito de receber uma resposta, mês que seja negativa, tal direito recebe a nomenclatura de

\footnotetext{
${ }^{1}$ Ministro do Supremo Tribunal Federal do Brasil
} 
Direito de Ação, preceito garantido pela Constituição Brasileira em seu Art. $5^{\circ}$, inciso XXXV2, ou seja, o ordenamento jurídico brasileiro garante a tutela jurisdicional a todos os interessados3. Nesta toada, a tutela jurisdicional é exercida pelo Estado-Juiz, detentor da Jurisdição (poder de dizer o direito), que uma vez provocado tem o dever de prestá-la a todo e qualquer interessado, todavia, algumas situações exigem uma resposta mais rápida por parte do Poder Judiciário, ao passo que a via eleita, via de regra para situações fundadas em urgência e evidência é a tutela provisória.

\subsection{Tutela provisória}

O atual Código de Processo Civil do Brasil trouxe à baila, em seu Livro V da Parte Geral, o instituto da Tutela Provisória. Buscando aclarar eventuais dúvidas, o legislador pátrio, no artigo 294, definiu o significado de "Tutela Provisória" eis que estabeleceu "A tutela provisória pode fundamentar-se em urgência ou evidência", trazendo a novidade da estabilização da medida, 4 em caso de ser deferida a liminar e não houver recurso. ${ }^{5}$

Não obstante, determina, parágrafo único do citado artigo, que: “A tutela provisória de urgência, cautelar ou antecipada, pode ser concedida em caráter antecedente ou incidental”.

\footnotetext{
${ }^{2}$ Art. $5^{\circ}$ Todos são iguais perante a lei, sem distinção de qualquer natureza, garantindo-se aos brasileiros e aos estrangeiros residentes no País a inviolabilidade do direito à vida, à liberdade, à igualdade, à segurança e à propriedade, nos termos seguintes: (...) XXXV - a lei não excluirá da apreciação do Poder Judiciário lesão ou ameaça a direito.

${ }^{3}$ Utilizamos o termo interessados, pois a Constituição Federal do Brasil de 1988, garante, no caput do seu artigo $5^{\circ}$, supracitado, igualdade de direitos, ou seja, aos brasileiros, bem como aos estrangeiros que aqui estiverem de forma permanente ou transitória, assim, a tutela jurisdicional é um direito constitucional de todo e qualquer interessado.

${ }^{4}$ Sobre a utilização da fórmula "eficácia provisória indefinidamente protraída", veja-se MANDRIOLI, Crisanto. I provvedimenti presidenziali nelgiudizio di separazione dei coniugii. Milano: Giuffré, 1953. p. 146; MANDRIOLI, Crisanto; CARRATTA, Antonio. Diritto processuale civile. 23. ed. Torino: Giappichelli, 2014. v. IV. p. 265-266. ${ }^{5}$ Destacamos alguns trabalhos sobre a égide do Código de Processo Civil de 2015: YARSHELL, Flávio Luiz. A tutela provisória (cautelar e antecipada) no novo CPC: grandes mudanças? (IX). Disponível em: [www.cartaforense.com.br]. Acesso em: 14.06.2016; RIBEIRO, Leonardo Ferres da Silva, Tutela provisória, São Paulo: RT, 2016; GOMES, Frederico Augusto; NETO, Rogério Rudiniki. Estabilização da tutela de urgência: algumas questões controvertidas. In: FREIRE, Alexandre; BARROS, Lucas Buril de Macedo; PEIXOTO, Ravi (Coord.). Coletânea Novo CPC: doutrina selecionada. v. 4. Cit., p. 161 ss.; WAMBIER, Luiz Rodrigues; TALAMINI, Eduardo. Curso avançado de processo civil. 16. ed. São Paulo: Ed. RT, 2016. v. 2. p. 859 ss.; CÂMARA, Alexandre Freitas. O nosso processo civil brasileiro. 2. ed. São Paulo: Gen-Atlas, 2016. p. 161 ss.; PINHO, Humberto Dalla Bernardina de. Direito processual civil contemporâneo. 6. ed. São Paulo: Saraiva, 2016. p. 522 ss.; NEVES, Daniel Amorim Assumpção. Manual de direito processual ci-vil. 8. ed. Salvador: JusPodivm, 2016. p. 449 ss.; COSTA, Eduardo José da Fonseca. Art. 304. In: STRECK, Lenio Luiz; CUNHA, Leonardo Carneiro da; NUNES, Dierle; FREIRE, Alexandre, (Coord.). Comentários ao Código de Processo Civil. São Paulo: Saraiva, 2016. p. 426 ss.; MEDINA, José Miguel Garcia. Novo Código de Processo Civil comentado. São Paulo: Ed. RT, 2015; MEDINA, José Miguel Garcia. Direito processual civil moderno. 2. ed., São Paulo: Ed. RT, 2016; DONIZETTI, Elpídio. Curso didático de direito processual civil. 19. ed. São Paulo: Gen-Atlas, 2016; MACIEL JR., Vicente de Paula. As tutelas de ur-gência no novo CPC brasileiro. In: SCRITTI in onore di Nicola Picardi. Pisa: Pacini Giuridica, 2016. p. 1603 ss.; ARRUDA ALVIM. Manual de direito processual civil. 17. ed. São Paulo: Ed. RT, 2017.
} 
Serve, então, a tutela provisória, conforme preceito processual atual, como um contíguo de tutelas diferenciadas, fundadas tanto na urgência quanto na evidência, utilizadas nos processos de conhecimento e de execução, e, principalmente, nas ações oriundas do direito de família, objeto do presente exame.

\subsection{Tutela de urgência}

Nos termos do quanto preconizado no artigo 300, do NCPC, a tutela de urgência será deferida quando forem explicitados os elementos que demonstrem a plausibilidade do direito, assim como o risco de dano irreparável ou de difícil ou impossível reparação. O parágrafo primeiro do artigo supra salienta que, na concessão liminar da tutela de urgência, o magistrado poderá fazer exigência de caução real ou fidejussória para que seja possível o ressarcimento dos danos que o requerido possa sofrer, resguardada a impossibilidade da parte que possua hipossuficiência econômica.

Ou seja, para que seja concedida a tutela de urgência, necessário se faz a observância de dois requisitos, que são o fumus boni juris, isto é, a probabilidade do direito, e o periculum in mora, que é, risco de que sem a medida o litigante possa sofrer perigo de prejuízo irreparável ou de difícil reparação.

Assim, o novo dispositivo exige apenas a comprovação da plausibilidade do direito e do risco de sofrer prejuízo irreparável ou de difícil reparação, atenuando em parte os requisitos para o deferimento da tutela antecipada de urgência, diferente do que ocorria na vigência do CPC/1973, quando era exigida a prova irrefutável e verossimilhança das alegações.

No que tange a utilização de tais medida no Direito de Família, a possibilidade de utilizar qualquer medida idônea para assegurar o direito controvertido que sofre perigo de prejuízo irreparável ou de difícil reparação nos termos do artigo 301 do NCPC, independentemente da nomenclatura a ser dada.

Oportuno frisar, que a tutela poderá ser pedida de forma antecedente seja antecipada ${ }^{6}$, bem como cautelar ${ }^{7}$, sendo que em ambos os casos cabe ao autor explicitar o pedido da tutela final, sendo que na antecedente, uma vez concedida a tutela, deve o autor aditar a petição inicial no prazo de 15 (quinze) dias, já na cautelar, o pedido principal deve ser formulado em petição própria pelo autor no prazo de 30 dias, ou seja, a diferença encontra-se na forma como o pedido

\footnotetext{
${ }^{6}$ Art. 303 e 304 do NCPC

${ }^{7}$ Art. 305 a 310 do NCPC
} 
principal será, posteriormente, realizado. Não obstante, a tutela pode fundar-se apenas em evidência, vejamos:

\title{
2.3 Tutela de evidência
}

A inaptidão do procedimento ordinário para solucionar conflitos em que a parte postule uma tutela jurisdicional mais célere, seja em decorrência de situação de perigo em que o seu direito se encontre, seja em decorrência do grau elevado de probabilidade de seus relatos serem julgados procedentes, se fez necessária a criação de métodos, tutelas diferencias, afim de compor o processo da indispensável instrumentalidade que o capacite a realizar os fins a que se propõe.

Ou seja, existe a possibilidade de conceder a tutela provisória por outros fundamentos que não seja a urgência para que o direito pretendido seja resguardado.

\begin{abstract}
A tutela provisória pode ser concedida por outros fundamentos que não a urgência. Há casos em que a medida se justifica não como meio de afastar um risco, mas para alterar os ônus que normalmente são carreados ao autor do processo e que decorrem da demora na sua conclusão. Em regra, é o autor quem os suporta e tem de aguardar o desfecho do processo, bem como o processamento de recursos, às vezes dotados de efeito suspensivo, para só então alcançar - em caráter provisório ou definitivo - o bem ou a tutela do direito pretendido. (GONÇALVES, 2017, p. 466)
\end{abstract}

O processo no qual há o pleito quanto a tutela de evidência, possui maior probabilidade de convicção quanto ao direito alegado, tendo em vista que o procedimento da evidência é incompatível com a realização da cognição sumária da demanda, uma vez que, conforme explicitado posteriormente, a relação processual estará concluída.

Sobre o direito evidente:

\begin{abstract}
"Os fatos, como sabido, são levados ao juízo através das provas, razão pela qual, quando se aduz a direito evidente, diz-se direito evidenciado ao juízo através das provas. Essa característica tem natureza mista material e processual. Sob o ângulo civil, o direito evidente é aquele que se projeta no âmbito do sujeito de direito que postula. Sob o prisma processual, é evidente o direito cuja prova dos fatos sobre os quais incide revela-os incontestáveis ou ao menos impassíveis de contestação séria." (FUX, 2000, p. 23-43)
\end{abstract}

Assim sendo, a tutela de evidência postulada pela parte, se caracteriza claramente por intermédio das provas carreadas na petição inicial, tornando dispensável, desta forma, que a parte requerente espere o desenrolar do processo para ver satisfeito seu direito evidente, o que poderia ser solucionado desde o início do litígio. 
O mecanismo em tela, em virtude do pleito de direitos mais evidentes que outros, carecem de prestação de uma tutela imediata, dispensando, portanto, a realização de uma cognição exauriente por parte do juiz, para que possa conferir ao requerente, o direito pleiteado.

\section{Aplicabilidade da antecipação de tutela no direito de família}

É sabido por todos que as relações referentes ao Direito de Família não suportam a morosidade do nosso judiciário, ou seja, os conflitos oriundos das relações familiares exigem uma tutela rápidas, capaz de evitar maior dano além daquele já experimentado pela própria natureza do conflito.

Certo, também, que o ordenamento jurídico brasileiro sempre houve sempre se preocupou com as questões atinentes ao Direito de Família, tanto é verdade que uma série de previsões para lidar com situações de urgência sempre se fizeram presentes. Com a nova sistemática processual introduzida pelo NCPC não foi diferente, eis que trouxe a lume, como dito acima, o instituto da Tutela Provisória, que abrange todas as situações urgentes relacionadas as demandas familiares.

Nesta toada, apresentaremos, primeiro, uma breve esboço sobre o Direito de Família, para logo após apresentar algumas situações prevista em legislação especial, e uma última (busca e apreensão) que era prevista no Código de Processo Civil anterior, contudo, não prevista pelo NPCP, contudo, ainda pertinente, tendo em vista a observância da Tutela Provisória, ou seja, o presente ensaio não é exauriente, no entanto, demonstrará que é possível e necessário aplicar as tutelas urgentes do Direito de Família.

\subsection{Direito de família}

Nossa Constituição Federal, conhecida como Constituição Cidadão, determinou o conceito de família na figura de base da estrutura da organização do Estado e da sociedade, sendo, portanto, carecente de proteção legal.

\footnotetext{
"Família em sentido genérico e biológico é o conjunto de pessoas que descendem de tronco ancestral comum; em senso estrito, a família se restringe ao grupo formado pelos pais e filhos; e em sentido universal é considerada a célula social por excelência." (PEREIRA, 2007, p. 20).
}

O Direito de família é o âmbito que mais carece de celeridade em relação ao desempenho jurisdicional, em decorrência de tal necessidade, as jurisprudências e doutrinas 
nacionais, buscam cada vez mais recursos para que o funcionamento processual dos litígios pertencentes a essa esfera seja resolvido de forma mais ágil, por meio de antecipação de tutelas, as quais possuem função de proteção de danos de caráter extrapatrimonial ou patrimonial dos integrantes da família.

No mesmo sentido:

\begin{abstract}
"No Direito de Família, a aplicação da tutela de urgência ganha contorno e cores muito mais vivas ante os valores que envolvem os litígios de família, sempre envoltos em questões que clamam por rápida solução, como a guarda e criação dos filhos, os alimentos, a culpa no desenlace, a integridade física e moral, a preservação e divisão dos bens, aquestos, patronímico, etc., enfim, a tudo somado a fragilidade psíquica e sensibilidade dos componentes da família, que veem o sonho das juras de amor se desfazer." (RODRIGUES, 2008, p. 45)
\end{abstract}

Em decorrência aos constantes conflitos que incluem ofensa aos direitos fundamentais, houve uma preocupação do legislador brasileiro em proporcionar proteção imediata, por meio de criação de mecanismos com a função de viabilizar prontidão na solução dos litígios que envolvem os princípios estabelecidos na Constituição Federal, por exemplo, dignidade da pessoa humana, vida, alimentos.

Ingo Wolfgang Sarlet define a dignidade da pessoa humana da seguinte forma:

“... a qualidade intrínseca e distintiva de cada ser humano que o faz merecedor do mesmo respeito e consideração por parte do Estado e da comunidade, implicando, neste sentido, um complexo de direitos e deveres fundamentais que assegurem a pessoa tanto contra todo e qualquer ato de cunho degradante e desumano, como venham a lhe garantir as condições existenciais mínimas para uma vida saudável, além de propiciar e promover sua participação ativa corresponsável nos destinos da própria existência e da vida em comunhão dos demais seres humanos." (SARLET, 2001, p. 60)

O fundamento do princípio da dignidade da pessoa humana está estabelecido de forma expressa no artigo $1^{\circ}$, inciso III, da Constituição Federal, cabendo dizer que deve ser observado em qualquer âmbito do direito, não unicamente ao familiar, como forma de garantia da efetividade da proteção dos direitos da pessoa humana perante a sociedade.

A lentidão para a confecção de uma decisão judicial que seja apta para solucionar litígios levados à juízo, principalmente, sob a tutela do Direito Familiar, é matéria de diversos debates sociais, doutrinários e até parlamentares, uma vez que são direitos inaptos de suportar soluções excessivamente paulatinas sem que ocorra o desrespeito às garantias mínimas e básicas fixadas na Constituição Federal como indispensáveis e fundamentais. 
Desta forma, à luz dos princípios constitucionais da não vedação de acesso à justiça e do devido processo legal, modernizando o ordenamento jurídico, inclusive na esfera do direito de família, o legisperito implementou a Lei no 5.478/1968, que aduz sobre a Ação de Alimentos; Lei $\mathrm{n}^{\mathrm{o}}$ 11.804/2008 aduzindo sobre Alimentos Gravídicos, todos, em amparo a maternidade e à infância; Na Lei n ${ }^{\circ}$ 10.406/2002, o Código Civil do ordenamento pátrio, encontrou prognóstico para a Guarda Provisória, dentre outros mecanismos que analisaremos abaixo.

\subsection{Alimentos provisionais e alimentos provisórios}

Na esfera do Direito Familiar, os alimentos provisionais e os provisórios são tópicos que figuram em uma pauta de temas de suma importância jurídica. Em decorrência da magnitude da matéria, a distinção entre as espécies de alimentos tem sido amplamente debatida pela doutrina. Em ambas as categorias de alimentos, o escopo do ordenamento jurídico é evitar que o suplicante permaneça em estado de penúria, tendo em vista que a manutenção de alimentos deve ser entendida como a manutenção de pecúnia, bens e até serviços essências.

\footnotetext{
"Alimentos abrange valores, prestações, bens ou serviços que digam respeito à satisfação das necessidades de manutenção da pessoa, seja decorrente de relações de parentesco, seja em face da ruptura de relações matrimoniais ou união estável, seja dos direitos de amparo ao idoso." (CARVALHO, 2012, p. 26).
}

Desta forma, entende-se como alimento aquilo que for necessário para a manutenção das necessidades básicas e do status da família, ou seja, o que for necessário para manter a subsistência familiar enquanto o litígio se desenvolve.

"A finalidade do instituto é prover o demandante dos meios necessários à sua subsistência enquanto durar o processo". (CÂMARA, 2007, p. 539).

A fome não espera, ou seja, alimentos devem ser prestados com a máxima urgência possível, pois aquele que necessita pode sofrer danos irreparáveis ou de difícil reparação se os alimentos não lhes forem prestados com a devida urgência.

\subsubsection{Alimentos provisórios}

Os alimentos provisórios são conduzidos por um rito especial delineado pelo artigo $1^{\mathrm{o}}$ da Lei $n^{0} 5.478 / 1968$, que têm de ser pleiteados no bojo de uma ação principal. Ainda que possuam caráter urgente e improrrogável, o processamento da ação de alimentos carece de 
extenso lapso temporal para que seja decidido, por conseguinte, surge o perigo de que a mora ocasione a ineficiência da prestação da tutela jurisdicional do Estado. Esta espécie de alimentos visa amparar as carências do alimentando desde o início do litígio, o qual visa a fixação de alimentos em caráter definitivo em proveito daquele.

A decisão interlocutória que concede ou nega o direito a prestação de alimentos provisórios tem o escopo de antecipar os efeitos de uma sentença futura que atingirá o direito do requerente, ou seja, equivale aos efeitos da antecipação de tutela. Ao julgar procedente o pedido, deverá o magistrado determinar o quantum a ser despendido pelo devedor, fundamental para suprir as necessidades do alimentando. Por oportuno, o escrivão, no prazo de 48 (quarenta e oito horas) encaminhará a segunda via do petitório, em companhia de cópia da decisão judicial, comunicando ainda data e hora para realização de audiência conciliatória ou de instrução e julgamento.

A lei específica determina que, para a propositura da ação de alimentos provisórios, a requerente deverá trazer a juízo um conjunto probatório que expresse a obrigação de alimentar, conforme preconiza o artigo $2^{\circ}$

\footnotetext{
"Art. $2^{\circ}$. O credor, pessoalmente, ou por intermédio de advogado, dirigir-se-á ao juiz competente, qualificando-se, e exporá suas necessidades, provando, apenas o parentesco ou a obrigação de alimentar do devedor, indicando seu nome e sobrenome, residência ou local de trabalho, profissão e naturalidade, quanto ganha aproximadamente ou os recursos de que dispõe."
}

A apresentação de conjunto probatório irrefutável de parentesco entre as partes ou da obrigação de alimentar da parte obrigada é requisito indispensável para a propositura da demanda. Neste sentido, “o exercício do Direito de Alimentos perfaz-se, dentre outros modos, através da Ação de Alimentos e é recíproco entre pais e filhos". (CARVALHO, 2012, p. 26).

“(...) provisórios dependem de prova pré-constituída do parentesco ou da obrigação de alimentar (art. 2 da Lei 5.478/68) (...). ” (ASSIS, 2002, p. 26).

Os incisos I e II, do artigo $2^{\circ}, \S 1^{\circ}$, da Lei 5.478/1968 preveem de forma expressa as hipóteses nas quais será dispensada a elaboração inicial de provas.

“ $\S 1^{\circ}$ Dispensar-se-á a produção inicial de documentos probatórios;

I - quando existente em notas, registros, repartições ou estabelecimentos públicos e ocorrer impedimento ou demora em extrair certidões.

II - quando estiverem em poder do obrigado, as prestações alimentícias ou de terceiro residente em lugar incerto ou não sabido." 
As exceções legais possibilitam a produção dos documentos probatórios em momento oportuno após a produção inicial de provas, todavia, em contrapeso, não exonera a autora da obrigação de anexar aos autos, provas pré-constituídas do direito alegado. Por conseguinte, entende-se que, não havendo a produção de provas constitutivas do direito da parte autora, necessitará esta postular pelas vias ordinárias o pagamento dos alimentos provisionais.

\subsubsection{Alimentos provisionais}

Os alimentos provisionais, são aqueles concedidos em medida cautelar, incidental ou preparatória e têm o escopo de garantir um amparo instantâneo à parte na tramitação da ação principal, independentemente de a matéria versar sobre anulação de casamento, separação judicial, alimentos, etc.

"a finalidade do instituto é prover o demandante dos meios necessários à sua subsistência enquanto durar o processo" (CÂMARA, 2007, p. 539).

O caráter definitivo deste instituto é outra característica relevante a ser considerada. Todavia, é equivocado considerar que os alimentos provisionais são definitivos, eis que é verossímil a revisão, por parte do magistrado, do valor fixado, pautando-se no binômio necessidade-possibilidade.

Ainda que os alimentos provisionais encontrem previsão nos artigos 1.694 a 1.710, do Código Civil, a matéria é regulada pelo Código de Processo Civil, no Livro III - do Processo Cautelar; Capítulo I, Seção VII, artigos 852 ao 854, transcritos a seguir.

\footnotetext{
“Art. 852 - É lícito pedir alimentos provisionais:

I - nas ações de desquite e de anulação de casamento, desde que estejam separados os cônjuges;

II - nas ações de alimentos, desde o despacho da petição inicial;

III - nos demais casos expressos em lei.

Art. 853 - Ainda que a causa principal penda de julgamento no tribunal, processar-seá no primeiro grau de jurisdição o pedido de alimentos provisionais.

Art. 854 - Na petição inicial, exporá o requerente as suas necessidades e as possibilidades do alimentante.

Parágrafo único - O requerente poderá pedir que o juiz, ao despachar a petição inicial e sem audiência do requerido, lhe arbitre desde logo uma mensalidade para mantença."
}

A espécie de alimentos em tela, ainda que possua estreita ligação com os alimentos provisórios, objetiva o sustento instantâneo do alimentando e sua prole durante toda a tramitação processual, compreendendo ainda o ônus sucumbencial. 
Sobre alimentos provisionais:

"Dizem-se provisionais, provisórios ou in litem os alimentos que, precedendo ou concomitantemente à ação de separação judicial, de divórcio, de nulidade ou anulação de casamento, ou ainda à própria ação de alimentos, são concedidos para a manutenção do suplicante, ou deste e de sua prole, na pendência do processo, compreendendo também o necessário para cobrir as despesas da lide." (CAHALI, 1998, p. 27.)

Nessa mesma perspectiva:

"Os alimentos provisionais são aqueles outorgados em liminar ou em sentença, a partir do regime previsto no Livro do "Processo Cautelar" (arts. 852 a 854 do CPC), ou, ainda, em liminar antecipatória, em qualquer ação que são cabíveis.” (MARINONI, 2008, p. 383.)

Nesse seguimento:

“Alimentos provisionais têm natureza de medida cautelar, seja ela preparatória, seja acidental, nas ações de divórcio, nulidade ou anulação de casamento, ou ainda nas ações de dissolução de união estável. (CARVALHO, 2012, p. 33.)

A medida liminar que assegura o resultado útil do processo em trâmite, ainda que tenha que cumprir os requisitos indispensáveis das medidas cautelares, ou seja, fumus boni juris8 e periculum in mora9, gera efeito de antecipação de tutela, tendo em vista que satisfaz, de forma total ou parcial, o quanto postulado pela parte autora, antecipando os efeitos de uma sentença com resolução de mérito. A decisão que arbitra a remuneração mensal destinada à manutenção do alimentando é proferida pelo juiz inaudita altera pars, contanto que requerida pela parte autora.

Ao defrontar-se com o requerimento de alimentos provisionais, deverá analisar a plausibilidade do direito levado a juízo e a verossimilhança do quanto alegado pela parte. Nesta oportunidade, ao contrário do que ocorre no caso de alimentos provisórios, há a dispensa da apresentação das provas pré-constituídas.

A sentença que dá provimento ao pedido de alimentos provisionais, ao transitar em julgado, deverá converter estes alimentos em definitivos, que poderão ser reanalisados, majorando, reduzindo ou ainda exonerando o devedor da respectiva obrigação, conforme aduz o artigo 1.699, do Código Civil.

\footnotetext{
8 "Fumaça do bom direito". É um sinal ou indício de que o direito pleiteado de fato existe.

9 "Perigo na demora". No direito brasileiro, é o receio que a demora da decisão judicial cause um dano grave ou de difícil reparação ao bem tutelado.
} 


\title{
3.3 Alimentos gravídicos
}

A Lei $n^{\circ}$ 11.804/2008 é a lei que trata dos Alimentos Gravídicos. A lei supra surgiu com a finalidade primordial de preencher a lacuna existente no ordenamento jurídico pátrio, no que se refere à prestação alimentícia ao nascituro, isto é, disciplina o direito de recebimento de alimentos pela mulher que se encontra em período de gestação.

Para melhor elucidação do assunto a ser tratado, é sensato que se traga à baila a lei em questão, com ressalva dos artigos vetados.

"Art. $1^{\circ}$ Esta Lei disciplina o direito de alimentos da mulher gestante e a forma como será exercido.

Art. $2^{\circ}$ Os alimentos de que trata esta Lei compreenderão os valores suficientes para cobrir as despesas adicionais do período de gravidez e que sejam dela decorrentes, da concepção ao parto, inclusive as referentes a alimentação especial, assistência médica e psicológica, exames complementares, internações, parto, medicamentos e demais prescrições preventivas e terapêuticas indispensáveis, a juízo do médico, além de outras que o juiz considere pertinentes.

Parágrafo único. Os alimentos de que trata este artigo referem-se à parte das despesas que deverá ser custeada pelo futuro pai, considerando-se a contribuição que também deverá ser dada pela mulher grávida, na proporção dos recursos de ambos.

Art. $6^{\circ}$ Convencido da existência de indícios da paternidade, o juiz fixará alimentos gravídicos que perdurarão até o nascimento da criança, sopesando as necessidades da parte autora e as possibilidades da parte ré.

Parágrafo único. Após o nascimento com vida, os alimentos gravídicos ficam convertidos em pensão alimentícia em favor do menor até que uma das partes solicite a sua revisão.

Art. $7^{\circ} \mathrm{O}$ réu será citado para apresentar resposta em 5 (cinco) dias.

Art. 11. Aplicam-se supletivamente nos processos regulados por esta Lei as disposições das Leis nos 5.478, de 25 de julho de 1968, e 5.869, de 11 de janeiro de 1973 - Código de Processo Civil.

Art. 12. Esta Lei entra em vigor na data de sua publicação".

Sobre alimentos gravídicos, há a seguinte concepção:

\begin{abstract}
“Alimentos gravídicos compreendem-se aqueles devidos ao nascituro, mas percebidos pela gestante ao longo da gravidez. Em outras palavras, constituem-se valores suficientes para cobrir despesas inerentes ao período de gravidez e dela decorrentes, da concepção ao parto, ou que o magistrado considere pertinente. $\mathrm{O}$ rol, portanto, não é exaustivo. ” (LOMEU, 2008, p. 58)
\end{abstract}

Na mesma toada:

“A Lei 11.804/08 procura proporcionar a mulher grávida um autêntico auxilio maternidade, sob a denominação latu sensu dos alimentos, representado por uma contribuição proporcional ao ser imposta ao suposto pai, sob forma de participação nas despesas adicionais do período de gravidez e que sejam delas decorrentes, da concepção ao parto, inclusive as referentes a alimentação especial, assistência médica e psicológica, exames complementares, internações, parto, medicamentos e demais prescrições prescritivas e terapêuticas indispensáveis, a juízo do médico, além de outras que o juiz considere pertinentes. "(CAHALI, 2012, p. 346.) 
Ainda que a Lei dos Alimentos Gravídicos tenha sido instituída no ano de 2008, o Tribunal de Justiça do Estado do Rio Grande do Sul, já contemplava com um julgado em $2003^{10}$ que reconheceu a necessidade da concessão de alimentos gravídicos ao nascituro:

Investigação de paternidade. Alimentos provisórios em favor do nascituro. Possibilidade. Adequação do quantum. 1. Não pairando dúvida acerca do envolvimento sexual entretido pela gestante com o investigado, nem sobre exclusividade sobre esse relacionamento, e havendo necessidade da gestante, justifica-se a concessão de alimentos em favor do nascituro. 2. Sendo o investigado casado e estando também sua esposa grávida, a pensão alimentícia deve ser fixada, tendo em vista as necessidades do alimentando, mas dentro da capacidade econômica do alimentante, isto é, focalizando tanto os seus ganhos como também os encargos que possui. Recurso provido em parte.

A lei tem o fito de resguardar as garantias básicas do homem nos termos do caput do artigo $5^{\circ}$, da Constituição Federal. Por ser a proteção à mulher gestante e em especial, ao concebido, o escopo principal da lei, esta difere das demais categorias de alimentos, visto que o direito aos gravídicos decorre da concepção de uma vida, independentemente da confirmação de existência de grau de parentesco.

Neste sentido:

"Os alimentos gravídicos são alimentos, como qualquer outro, previsto no Código Civil decorrente da mesma origem: poder familiar. Contudo, aqueles são fixados com base em meros indícios de paternidade". (VENOSA, 2009, p. 366.)

Ante o quanto ponderado no entendimento supra, é de suma importância apreciar os indícios de paternidade, tendo em vista que a gestante deverá, no mínimo, levar a apreciação do magistrado, documentos com o fito de comprovar a gestação, devendo comprovar ainda a existência de relacionamento afetivo com o provável genitor a ser apontado, restando desnecessária a apresentação de prova pré-constituída quanto a paternidade.

O legislador se contentou com a exibição dos indícios da paternidade. Neste sentido, deixa de ser primordial a demonstração de prova irrefutável quanto ao compromisso de alimentar, tendo em vista se tratar de juízo de cognição ampla. Os meios conclusivos são dos mais diversos, desde a existência de contratos conjuntos, existência de fotos, até mesmo o depoimento testemunhal de pessoas que tenham ciência da existência de relação entre os litigantes, e neste ínterim, houve a concepção, são indícios satisfatórios de paternidade para que o magistrado arbitre os alimentos.

\footnotetext{
${ }^{10}$ BRASIL. Tribunal de Justiça do Estado do Rio Grande do Sul. Agravo de instrumento no 70006429096 , Sétima Câmara Cível. Relator: Sérgio Fernando de Vasconcellos Chaves, julgado em 13 ago. 2003.
} 


\subsection{Busca e apreensão}

A medida cautelar de busca e apreensão de menor dispõe de caráter pessoal, antes prevista nos artigos 839 ao 843 do Código de Processo Civil de 1973, incidia no Direito de Família, sobre menor e incapazes para efetivação de cumprimento das decisões proferidas em ações de ruptura de vínculos matrimoniais (dissolução, separação, divórcio ou anulação); em ações que tratem sobre a visitação e a guarda dos filhos, menores ou incapazes ou ainda em ações que versem sobre a destituição do poder familiar.

A ação de busca e apreensão é um "procedimento judicial geral consistente na procura e, sendo prospera, em seguinte apreensão de bens móveis e/ou pessoas incapazes." (MOUZALAS, 2012, p. 341.)

Para outros doutrinadores:

\footnotetext{
"Busca 'é a procura, a cata, a pesquisa de uma coisa ou pessoa'. É o ato que não esgota em si mesmo sua finalidade. Vem sempre ligado ao seu complemento que é a "apreensão" da coisa buscada. Não há separação ou autonomia entre os dois atos. "Há seguimento, o buscar e o apreender, que depende do bom exito da busca." Há, portanto, verdadeira fusão dos dois atos.” (THEODORO JR., 2002, p. 294.)
}

No tocante da presente análise, quando o objeto da busca e apreensão recai sobre pessoas, "sendo este o seu objeto, não poderá seguir o rito das tutelas de urgência, por comprometer o contraditório." (MOUZALAS, 2012, p. 341.), a ação em espeque que tem seu ajuizamento com o fito de solução de conflitos que tratem sobre a guarda de incapaz, não se se aproveita para ser proposta sob a égide do rito sumário tendo em vista que este não gera ensejo a possibilidade de disposições que versem sobre matéria de mérito, necessitando, portanto, ser processada e julgada como ação cognitiva pelas vias ordinárias.

Todavia, na sistemática processual atual, tal instituto foi excluído, eis que o NCPC, além de não repetir o procedimento de busca e apreensão de forma especifica, extinguiu as medidas cautelares típicas.

Todavia, podemos realizar o pedido de busca e apreensão de menor com base na Tutela Provisórias, que serão de urgência, ou de evidência. Por oportuno, lembramos que as tutelas de evidência nunca serão antecedentes, eis que depende de um pedido principal já formulado.

Como o NCPC prevê a possibilidade de tutelas antecedentes de urgência, sejam elas cautelares ou satisfativas, serem realizadas antecedentes ou incidentais, a busca e apreensão de menor, quando demonstrada a necessidade encontra guarida processual. 
Sobre o tema, Fernanda Tartuce argumenta:

A tutela provisória é usada, por exemplo, quando se fala em busca e apreensão de menores, nesses casos ela pode estar fundada em urgência (quando requerida na forma de pedido cautelar ou tutela antecipada) ou ser uma simples medida de efetividade de um direito já definido. ${ }^{11}$

Resta evidente, que o NCPC assegura as medidas previstas como procedimento cautelar especifico no Código de Processo Civil anterior, no novo instituto da Tutela Provisória.

Assim, a aplicabilidade da tutela antecipada e/ou cautelar (liminares) no Direito de Família é medida de extrema utilidade. Não obstante, impende salientar que o NCPC, repisese, garante toda e qualquer medida necessária para assegurar direitos tão importantes, desde alimentos a busca e apreensão conforme supracitado.

\section{Conclusão}

A delonga dos procedimentos da prestação judicial, no que diz respeito à solução imediata dos direitos fundamentais e indisponíveis de cada indivíduo, sempre foi problemática do direito brasileiro. Por isso, o legislador ao elaborar o Novo Código de Processo Civil preocupou-se em criar medidas e procedimentos que proporcionam maior celeridade na resolução dos conflitos levados ao Poder Judiciário.

Tais medidas foram disciplinas em livro especifico no NCPC, ou seja, em seu Livro V da Parte Geral, o instituto da Tutela Provisória fora disciplinado.

Várias foram as inovações da nova sistemática processual, seja a criação/tipificação da figura da Tutela Provisória; seja a não inclusão de cautelares especificas; seja a criação da tutela de evidência, dentre tantas outras inovações.

Certo, que várias foram as dúvidas em relação aos procedimentos que anteriormente existiam e que não foram contemplados pelo novo Código, dúvidas essas que até os dias atuais ensejam calouros debates doutrinários e jurisprudências no Brasil.

Assim, analisar se a aplicabilidade da tutela antecipada e/ou cautelar (liminares) no Direito de Família é medida de extrema utilidade, é tema que por si só se justifica. 11 Disponível em: http://ibdfam.org.br/noticias/6062/A+tutela+provis\%C3\%B3ria+no+CPC+2015. Acesso em:
23/02/2018 
Contudo, conforme demonstrado acima, o Direito de Família exige rapidez na solução de seus conflitos, pois o dissabor suportado pelas partes envoltas a pendenga causa tanta amargura que um processo moroso em nada ajudará, muito pelo contrário.

Nesta toada, necessário reconhecer que o NCPC garante a aplicabilidade da tutela antecipada e/ou cautelar (liminares) no Direito de Família, seja de forma antecedente ou incidental.

\section{Referências bibliográficas}

ARRUDA ALVIM. Manual de direito processual civil. 17. ed. São Paulo: Ed. RT, 2017.

ASSIS, Araken de. Manual do Processo de Execução. 8. ed. São Paulo: Revista dos Tribunais, 2002.

CAHALI, Yussef Said. Dos alimentos. 7 Ed. rev. e atual. São Paulo: Revista dos Tribunais, 2012.

CÂMARA, Alexandre Freitas. Lições de Direito Processual Civil. Vol. III. Rio de Janeiro: Lúmen Júris. 2007.

CÂMARA, Alexandre Freitas. Lições de direito processual civil. 19. Ed. Vol. 2. São Paulo: Atlas, 2012.

CÂMARA, Alexandre Freitas. O nosso processo civil brasileiro. 2. ed. São Paulo: GenAtlas, 2016.

CARVALHO, Dimitre Braga Soares. Leis Especiais para Concursos. Vol. 32. Leis Civis Especiais no Direito de Família - 2 ed: Rev., amp. e atual. Editora Jus Podivm, 2012.

FREIRE, Alexandre; BARROS, Lucas Buril de Macedo; PEIXOTO, Ravi

(Coord.). Coletânea Novo CPC: doutrina selecionada. Editora Jus Podivm, 2015, v. 4. 
FUX, Luiz. A tutela dos direitos evidentes. Jurisprudência do Superior Tribunal de Justiça, Brasília, ano 2, nº 16, p. 23-43, 2000.

. Tutela jurisdicional: finalidade e espécies. Informativo Jurídico da Biblioteca Ministro Oscar Saraiva. STJ. 2002 - Disponível em: http://www.stj.jus.br/publicacaoin stitucional//index.php/informativo/article/view/397/356. Acesso em: 23/02/2018

GONÇALVES, Marcus Vinicius Rios. Direito processual civil esquematizado®. - 8. ed. São Paulo: Saraiva, 2017.

LOMEU, Leandro Soares. Alimentos gravídicos. Revista Jurídica Consulex. Ano XII - N 285,30 de novembro de 2008 .

MACIEL JR., Vicente de Paula. As tutelas de urgência no novo CPC brasileiro. In: SCRITTI in onore di Nicola Picardi. Pisa: Pacini Giuridica, 2016.

MANDRIOLI, Crisanto. I provvedimenti presidenziali nelgiudizio di separazione dei coniugii. Milano: Giuffré, 1953.

MANDRIOLI, Crisanto; CARRATTA, Antonio. Diritto processuale civile. 23. ed. Torino: Giappichelli, 2014. v. IV.

MARINONI, Luiz Guilherme. Curso de Processo Civil. Vol. 3: execução. 2 Ed. rev. e atual. 2 tir. - São Paulo: Editora Revista dos Tribunais, 2008.

MEDINA, José Miguel Garcia. Novo Código de Processo Civil comentado. São Paulo: Ed. RT, 2015;

MEDINA, José Miguel Garcia. Direito processual civil moderno. 2. ed., São Paulo: Ed. RT, 2016;

MOUZALAS, Rinaldo. Processo Civil. 3 Ed. revista, ampliada e atualizada, Bahia, Editora JusPodivm, 2012. 
NEVES, Daniel Amorim Assumpção. Manual de direito processual civil. 8. ed. Salvador: JusPodivm, 2016.

RIBEIRO, Leonardo Ferres da Silva. Tutela provisória. São Paulo: RT, 2016.

PEREIRA, Caio Mário da Silva. Instituições de Direito Civil. Vol. V - Direito de Família. 16. ed. Rio de Janeiro: Editora Forense, 2007.

PINHO, Humberto Dalla Bernardina de. Direito processual civil contemporâneo. 6. ed. São Paulo: Saraiva, 2016.

RODRIGUES, Luiz Fernando Afonso. Tutela de Urgência no Direito de Família. São Paulo: Quartier Latin, 2008.

SARLET, Ingo Wolfgang. A eficácia dos direitos fundamentais. $2^{a}$ ed. Porto Alegre: Livraria do Advogado, 2001.

STRECK, Lenio Luiz; CUNHA, Leonardo Carneiro da; NUNES, Dierle; FREIRE, Alexandre, (Coord.). Comentários ao Código de Processo Civil. São Paulo: Saraiva, 2016.

TARTUCE, Fernanda. A tutela provisória no CPC 2015. Disponível em:

http://ibdfam.org.br/noticias/6062/A+tutela+provis\%C3\%B3ria+no+CPC+2015. Acesso em: $23 / 02 / 2018$

THEODORO JÚNIOR. Humberto. Antecipação de tutela e medidas cautelares. Tutela de emergência. RJ, n. ${ }^{\circ}$ 253, 1998. CD Juris Síntese Millennium, nº 34. São Paulo: Síntese, 2002.

VENOSA, Sílvio de Salvo. Direito Civil. Direito de família. Vol. 6. Coleção direito civil. 9. ed. São Paulo: Atlas, 2009.

WAMBIER, Luiz Rodrigues; TALAMINI, Eduardo. Curso avançado de processo civil. 16. ed. São Paulo: Ed. RT, 2016. v. 2. 
YARSHELL, Flávio Luiz. A tutela provisória (cautelar e antecipada) no novo CPC:

grandes mudanças? (IX). Disponível em: [www.cartaforense.com.br]. Acesso em: 14.06.2016. 


\title{
AUTONOMIA PRIVADA E A (IM)POSSIBILIDADE DE RENÚNCIA A DIREITO FUNDAMENTAL: EUTANÁSIA E SUICIDIO ASSISTIDO
}

\author{
Edilene Lobo \\ Universidade de Itaúna $-M G$ \\ Suzana Oliveira Marques Brêtas \\ Universidade de Itaúna - MG
}

\section{Resumo}

O presente artigo indaga acerca da possibilidade de aplicação dos institutos explorados, eutanásia e suicídio assistido, na realidade brasileira, para aferir, sob o paradigma da dignidade da pessoa humana, qual o grau de autonomia privada lá admitido para se renunciar ao direito fundamental à vida. Ainda, é seu objetivo incursionar pelas denominadas diretivas antecipadas de vontade, testamento vital e mandato duradouro, para perquirir sua utilidade, focando a literatura, a jurisprudência e legislação aplicável.

Palavras-chave: Direito à vida, Autonomia privada, Eutanásia, Suicídio assistido, Diretivas antecipadas de vontade.

\begin{abstract}
Resumen/Résumé
This article asks about the possibility of the explored institutes application, euthanasia and assisted suicide, to the Brazilian reality in order to gauge, under the dignity of the human person paradigm, what is the private autonomy measure admitted there to be able to renounce the fundamental right to life. Further, it is its objective to foray through the advance directives, living will and healthcare proxy, to inquire its utility, focusing the literature, jurisprudence and applicable legislation.
\end{abstract}

Keywords/Palabras-claves/Mots-clés: Right to life, Private autonomy, Euthanasia; Assisted suicide, Advance directives. 


\section{Introdução}

Os institutos jurídicos sofrem transformações, ocasionadas por múltiplos fatores que acompanham os avanços e retrocessos das relações humanas, sempre complexas.

Nos últimos tempos, as sociedades, não só no Brasil, como no mundo, vivenciaram grandes transformações políticas, econômicas, tecnológicas e culturais. Essas mudanças influenciam o sistema jurídico, que é produto da inteligência humana e, de forma significativa, a vida, direito fundamental.

O presente trabalho tem por objetivo, nessa nave, a análise das possibilidades, ou não, de relativização do direito fundamental à vida, filtrando-o pelos princípios da dignidade e da autonomia privada. Ao fazê-lo busca aferir as concepções havidas sobre eutanásia, ortotanásia, distanásia e suicídio assistido, bem como sobre testamento vital e mandato duradouro, examinando a legislação brasileira e alienígena para conferir se haveria base comum de aplicação e se acúmulos de outras culturas ajuda na intepretação e aplicação dos institutos na realidade local.

O referente teórico, no entorno do qual gira a pesquisa, é a dignidade da pessoa humana, pilar do estado democrático de direito e vetor da sociedade livre, justa e solidária, viabilizadora da autonomia de seus membros, anunciada pela Constituição do Brasil há trinta anos, desde seus artigos $1^{\circ}$ e $3^{\circ}$, e que permitirá evoluir acerca da indagação posta, rumo à compreensão do significado de direito fundamental.

Lançando mão da revisão bibliográfica, jurisprudencial e legislativa, como método de pesquisa, se concluirá, conforme apresentado ao final, que se tem dado especial relevância à dignidade também quando se tratar de dar final à vida - não só para sua vivência plena e boa o que só é possível com o surgimento de institutos legais promissores, em novel concepção de direitos fundamentais.

\section{Vida, dignidade humana e autonomia privada}

Vida é palavra dissílaba, pequena, porém com inúmeros significados que extrapolam a ciência do direito e a tornam grandiosa. É certo que seu início e término envolve situações cujas respostas também passam pela medicina, religião e costumes.

Basta ver que o Conselho Federal de Medicina, por meio da Resolução de $n^{\circ}$ 1.957/2010, que revogou a Resolução $n^{0}$ 1.358/1991, fixando normas éticas para as técnicas de 
reprodução assistida, estabeleceu que até 14 dias, após a concepção, o ser biológico não é pessoa, pois poderia ocorrer o seu descarte.

Muito embora, como bem se sabe, o artigo 4\%/1 da Convenção Americana de Direitos Humanos estabeleça que "a proteção da vida se dá desde a concepção, avançando com a proposição de uma dimensão objetiva dos direitos à vida e à saúde, assim como de uma dimensão coletiva de sua titularidade.” (SARLET, 2015, p. 228)

As religiões também possuem significados divergentes sobre a etimologia da palavra vida, que pode expressar fim, começo, mudança ou passagem.

$\mathrm{Na}$ ciência jurídica existem teorias construídas de acordo com as características peculiares de determinado lugar e fixam critério inicial da existência humana para fins de aquisição de direitos.

No Brasil há, basicamente, duas teorias, as natalistas e as concepcionistas. Segundo César Fiúza, "a primeira defende a tese de que o nascituro só adquire personalidade após o nascimento com vida. A segunda, ao contrário, propugna pela tese de que a personalidade começa desde a concepção da vida no útero materno." (FIÚZA, 2008, p. 124).

Vida é tudo que vibra e palpita, é existência, significar, vitalidade, força, fervor, ânimo, exuberância, dinamismo, vivacidade, energia, existência, comportamento, governança, dentre outros significados (AZEVEDO, 2010, p. 1, 151, 153, 574, 682, 692).

Não se pode falar em vida sem pensar na morte, eis que o ser vivente morre um pouco a cada dia desde o seu nascimento.

A morte pode ser negação da existência, desconhecimento, fim, termo, derradeira etapa, mudança de ação para repouso, destruição, definhamento progressivo e rápido, por exemplo (AZEVEDO, 2010, p. 2, 67, 142, 162, 360).

$\mathrm{Na}$ medicina, em passado recente, a morte era configurada com a parada cardíaca, porém, após o primeiro transplante cardíaco realizado na África do Sul, pelo médico Christian Barnard, o Comitê da Havard Medical School passou a definir como termo da vida a morte encefálica (SÁ; NAVES; 2011, p. 294). Nessa linha, a Resolução nº 1.480 do Conselho Federal de Medicina fixa exames e dados clínicos que deverão ser feitos e observados para a configuração da morte encefálica.

A Constituição brasileira, como paradigma essencial, consagra a dignidade da pessoa humana como um de seus fundamentos, consoante art. $1^{\circ}$, inciso III, e daí se parte para aferição da vida e da morte sob tal orientação. 
A dignidade é inerente à pessoa humana e todos a devem possuir, independentemente de credo, condição social, econômica, saúde ou sua ausência, escolaridade, raça, opção sexual, dentre outros fatores. A sociedade plural pressupõe respeito a todas essas diferenças.

Assim como a palavra vida, dignidade também possui várias acepções, podendo significar classe, altura, nível, talento, intelecto, inteligência, reputação, renome, condição social, grandeza, honrarias, distinção, altivez, amor-próprio, respeitabilidade, honradez, ministério e ofício (AZEVEDO, 2010, p. 71, 498, 873/878, 939, 995).

Seguindo esse mesmo pensamento é a doutrina dos autores espanhóis Rafael Junquera de Estéfani e F. Javier de la Torre Dáz, sustentando que o termo dignidade possui diversos significados.

Assim, existe a dignidade social que está relacionada ao cargo, função e autoridade. Também, a dignidade moral, que vem a ser comportamento adequado e socialmente aceito. Por fim, a dignidade como valor inerente à pessoa humana (ESTÉFANI; DÍAS; 2014, p. 191/192).

Como bem salientou José de Oliveira Ascensão: “O homem é um ser social. Não apenas por viver em agregados, mas por que a sua realização se faz com os outros, pelos outros e para os outros" (ASCENSÃO, 2003, p.11).

Atrelado à dignidade da pessoa humana está a autonomia privada. Autonomia é a manifestação intencional e livre de uma pessoa capaz (SIDOU, 2009, p. 88).

No ordenamento jurídico brasileiro, quando a pessoa não tem condição de se manifestar serão respectivamente representadas ou assistidas, conforme hipóteses descritas nos $\operatorname{artigos} 3^{\circ}$ e $4^{\circ}$ do Código Civil.

Autonomia, indubitavelmente, está relacionada à ideia de liberdade, sendo que a constituição de uma sociedade livre é um dos fundamentos da República Federativa do Brasil, conforme norma do art. $3^{\circ}$, I, da Constituição.

Importante distinguir autonomia da vontade de autonomia privada. Isso porque, a autonomia teve como fonte inicial de discussão o direito das obrigações e não questões existenciais.

A autonomia da vontade tinha aspecto meramente formal, até a Constituição atual, que consagrou como inspiração maior a dignidade da pessoa humana, ao lado da função social da propriedade, dentre outros importantes direitos individuais.

Dessa forma, a autonomia deixou de ter concepção meramente formal, inspirada no positivismo, passando a ser vista como a possibilidade real e efetiva de "se autogovernar, e, por consequência, o detentor de autonomia tem a faculdade de se reger por um sistema de regras reconhecidas pelos demais", como diz J.M Othon Sidou (SIDOU, 2009, p. 88). 
Não se trata de autonomia absoluta, por suposto, eis que se vive sob o manto do Estado Democrático de Direito, no qual vigora a reserva legal. Contudo, essencial compatibilizar liberdade e legalidade, princípios constitucionais e direitos individuais consagrados na Constituição.

De posse desse raciocínio, a autonomia deve ser observada em todas as fases da vida, inclusive naquela terminal, cuja definição será encontrada na ciência médica.

César Fiúza considera "paciente terminal, aquele que, a despeito das tentativas médicas, não responde a nenhuma medida terapêutica aplicada." (FIÚZA, 2009, p. 95).

Em tese, se a pessoa não pode mais exercer sua autonomia pessoalmente, esta deverá ser exercida por seu representante legal.

Na fase terminal da vida, uma das formas de exercício da autonomia é o consentimento conscientizado que implica no dever do médico de informar ao paciente sobre o seu real estado de saúde, suas perspectivas de vida, quais os tratamentos disponíveis e suas chances de cura.

A informação dever ser dada por meio de linguagem acessível.

A partir de uma explicação clara, objetiva e minuciosa, o paciente, com fundamento na sua autonomia, pode definir a que tipo de tratamento está sujeito a se submeter. $\mathrm{O}$ consentimento informado deve ser escrito, embora se admita a forma verbal, conforme será analisado oportunamente, quando se tratar do testamento vital e do mandato duradouro.

A vida surge ou acontece de forma involuntária. A partir do nascimento, dentro de uma situação de normalidade ou ordem natural, a lógica é a autodefesa, em busca do melhor. Partindo dessas premissas a morte deveria ser involuntária.

Todavia, há situações excepcionais, como as que aqui se comenta, em que, embora se esteja tecnicamente vivo, em razão do auxílio de aparelhos tecnológicos, já não se mantém qualquer ligação, interação ou relação sustentável com o mundo real.

Será que nestas situações excepcionais não é possível exercer autonomia e o livre arbítrio para se ter o direito de morrer com dignidade? É mesmo do Estado, em contrapartida, o dever de se imiscuir nessa esfera tão íntima, para toldá-la?

A resposta é rotunda negativa!

\section{Eutanásia, suicídio assistido, ortotanásia e distanásia}

Como se espera de institutos tão complexos, há divergências doutrinárias acerca das ideias e noções sobre eutanásia, suicídio assistido, ortotanásia e distanásia. 
Segundo Maria de Fátima Freire de Sá e Bruno Torquato de Oliveira Naves, eutanásia "é a conduta, por meio da ação ou omissão do médico, que emprega, ou omite, meio eficiente para produzir a morte do paciente incurável e em estado de grave sofrimento, diferente do curso natural, abreviando-lhe a vida." (SÁ; NAVES; 2011, p. 312)

A eutanásia pode decorrer de uma conduta ativa ou passiva. Neste último caso se está diante da ortotanásia.

Os que defendem a eutanásia argumentam que a finalidade é afastar o sofrimento da pessoa em fase terminal, além de lhe permitir que possa morrer de forma digna (v.g., há doenças que desfiguram, além de gerar dependência da boa vontade e da caridade de terceiros, o que para alguns não é aceitável e torna a existência um tormento).

Quando o doente deixa o consentimento informado, por escrito, a questão é menos complexa no que se refere ao exercício da autonomia, embora a eutanásia seja considerada ilícito criminal, em vários países.

O tema é difícil, também por isso, pois envolve o direito penal, a ciência médica, a psicologia, culturas, religiões, tradições, aspectos patrimoniais e sucessórios. Como dito:

É clara a divisão de posições em nossa sociedade. A eutanásia e o suicídio assistido são defendidos por alguns como possibilidade moral e legal em nome da dignidade da pessoa. Para outros, tais práticas são uma violação da mesma. (ESTÉFANI; DÍAZ, 2014, p. 202)

A distanásia, também denominada obstinação terapêutica, ao contrário da eutanásia, tem por objetivo prolongar a vida do paciente por meio de aparelhos artificiais e desproporcionais. A distanásia está relacionada ao desenvolvimento tecnológico e por isso deve ser examinada com cautela, uma vez que não deve ser utilizada para fins exclusivamente financeiros, tanto do ponto de vista dos médicos como do ponto de vista familiar. Eis que, muitas vezes, a manutenção da sobrevida de alguém pode objetivar benefício patrimonial de terceiro.

Mistanásia é a morte da pessoa que sequer chegou a ser paciente. É a morte prematura que ocorre em razão de vários fatores, quais sejam: a) precariedade dos serviços de atendimento, muito comum em países latinos e africanos, b) miséria, c) genocídio, d) erro médico, dentre outros. Por suas características não envolve maiores considerações neste trabalho.

O suicídio assistido e a eutanásia, sim. Embora sejam semelhantes, não se confundem, pois, no suicídio assistido, a conduta é praticada pelo próprio paciente.

A par da doutrina: 
Diferentemente, no suicídio assistido, a morte não depende de forma direta da ação de terceiro. Ela ocorre por ato do próprio paciente, que pode ser orientado, auxiliado ou observado por médico ou terceiro. (BONTEMPO, 2011, p. 78)

Segundo doutrina de Ricardo Vergueiro Figueiredo:

$\mathrm{Na}$ visão do ordenamento jurídico-penal, entendemos o suicídio como a eliminação pelo homem, isto é, por suas próprias mãos, de sua vida, realizada de forma voluntária e consciente. Tal conceito, por si só, já indica de maneira implícita que o ofendido deve ter capacidade de discernimento para compreender a conduta que pratica. (FIGUEIREDO, 2001, p. 45)

O suicídio não é considerado ilícito penal no Brasil, mas seu induzimento, instigação ou auxílio, são punidos.

A doutrina, como era de se esperar, diverge acerca da possibilidade ou do direito de morrer.

Ortotanásia, para alguns a eutanásia passiva, ocorre em razão da ausência de intervenção médica, não se tratando de conduta negligente. Simplesmente o médico deixa a morte ocorrer de forma natural e espontânea. O paciente não é submetido a tratamentos que possam adiar a sua morte (distanásia).

A ortotanásia baseia-se em cuidados paliativos, implicando cuidado ativo com a doença que não mais responda a tratamentos direcionados à cura.

Ou seja, a base do tratamento envolve o controle da dor, os problemas psicológicos, sociais, espirituais e a interação do paciente com sua família e amigos, fulcrando melhor qualidade do que resta da vida.

Em geral os cuidados são feitos por equipe multidisciplinar composta por médico, fisioterapeuta, terapeuta ocupacional, fonoaudiólogo, farmacêutico, biomédico, equipe de enfermagem, psicólogo e algum profissional ligado ao campo religioso como um padre ou pastor.

A finalidade é aliviar a dor do paciente e, não raro, da própria família, tocada pela situação de indignidade com tratamentos invasivos e sem chance de cura.

\section{Testamento vital e mandato duradouro}

Aqui também há divergência doutrinária no que diz respeito às nomenclaturas diretivas antecipadas, testamento vital e mandato duradouro. Parte da doutrina vislumbra diretivas 
antecipadas como gênero, dos quais são espécies: testamento vital e mandato duradouro. Contudo, outra parte da doutrina entende que diretivas antecipadas e testamento vital são expressões sinônimas.

Elisa Castro Cruz define testamento vital como "espécie de diretiva antecipada por meio da qual a pessoa declara os tratamentos médicos a que deseja ser submetida ou não em caso de incapacidade decorrente de doença ou acidente" (CRUZ, 2013, p.46).

O Código Civil atual não define testamento, contudo sua noção e características essenciais podem ser extraídas dos artigos 1857 e 1858.

O testamento é negócio jurídico e possui as seguintes características:

a) ato personalíssimo exclusivo do autor da herança - não se admite a confecção de testamento através de procurador;

b) negócio jurídico unilateral - se aperfeiçoa com uma única manifestação de vontade;

c) solene - somente terá validade se forem observadas todas as formalidades essenciais previstas em lei, objetivando assegurar autenticidade e liberdade do testador;

d) gratuito - testador não visa obtenção de vantagem;

e) revogável - é invalida qualquer cláusula testamentária que impeça a revogação do testamento;

f) causa mortis - o testamento produz efeito somente após a morte do testador.

Diante dessas características, a nomenclatura testamento vital não é a mais adequada, eis que negócio jurídico "inter vivos" e testamento é negócio jurídico "causa mortis". As diretivas antecipadas ou testamento vital, a para da melhor doutrina, "é um documento sem qualquer cunho patrimonial" (DADALTO, 2013, p. 62).

De sorte que testamento, como regra, contém disposições patrimoniais, embora possa conter disposições não patrimoniais, tal qual estabelece o Código Civil.

O testamento típico é negócio jurídico solene, enquanto que as diretivas antecipadas ou testamento vital podem ser celebrados através das seguintes formas:

a) escritura pública celebrada no cartório de notas;

b) documento particular com firma reconhecida em cartório;

c) declaração feita ao médico assistente, registrada em prontuário e assinada; e

d) hipótese de paciente que declarou verbalmente a amigos e familiares sua resistência a esforço terapêutico. (SÁ; NAVES; 2011, p. 333/334)

O testamento vital também possui outras denominações, quais sejam: testamento biológico, diretivas antecipadas de tratamento, declaração antecipada de vontade, declaração 
antecipada de tratamento e declaração prévia de vontade de paciente terminal. (ALVES, 2013, p. 427)

O mandato duradouro é modalidade de diretivas antecipadas em que o doente indica uma terceira pessoa que terá poderes para fazer escolhas de tratamentos médicos na hipótese de sua inconsciência.

\section{Legislação brasileira e estrangeira}

A Resolução n ${ }^{\circ} 1.995 / 2012$, do Conselho Federal de Medicina, dispõe sobre as diretivas antecipadas de vontade dos pacientes, no artigo $1^{\circ}$, e mandato duradouro, no artigo $2^{\circ}$.

Em relação à eutanásia, no ordenamento jurídico brasileiro não há regra expressa, embora o artigo 121 do Código Penal puna o homicídio.

No $\S 1^{\circ}$ do artigo 121 do Código Penal há a hipótese de homicídio privilegiado, que ocorre quando o agente comete o crime impelido por motivo de relevante valor social ou moral, ou sob o domínio de violenta emoção, logo em seguida à injusta provocação da vítima, o que possibilita redução da pena de um sexto a um terço.

Conforme já mencionado, o suicídio no Brasil não é ilícito criminal, contudo, o Código Penal, na norma do art. 122, pune quem induz ou instiga alguém a suicidar ou presta-lhe auxílio para que o faça.

No Brasil, a eutanásia tem tido tratamento de homicídio privilegiado.

Em relação à ortotanásia, a Resolução do Conselho Federal de Medicina, de $n^{\circ}$ 1.805/2006, prevê que, na fase terminal de enfermidades graves e incuráveis, é permitido ao médico limitar ou suspender procedimentos e tratamentos que prolonguem a vida do doente, garantindo-lhe os cuidados necessários para aliviar os sintomas que levam ao sofrimento, na perspectiva de uma assistência integral, respeitada a vontade dele ou de seu representante legal.

No Estado de São Paulo, a Lei no 10.241/1999 permite ao paciente recusar tratamento doloroso ou extraordinário para tentar prolongar sua vida.

\subsection{Eutanásia na legislação estrangeira}

No âmbito internacional, a questão sobre eutanásia é controvertida, embora alguns países já possuam legislação mais densa e amadurecida que a brasileira. 
Em recente matéria jornalística ${ }^{1}$, dando conta da atualidade e importância do tema, foi noticiada a decisão tomada pelo cientista australiano, David Goodall, de 104 anos, que optou pelo suicídio assistido em razão da piora em sua qualidade de vida.

Sem sofrer qualquer tipo de doença terminal e estar em pleno gozo de suas faculdades mentais, Goodall precisou realizar o procedimento em uma clínica especializada na Suíça, Eternal Spirit, pois na Austrália o ato ainda não é autorizado em todo o país, apenas no estado de Victoria, onde foi legalizado no ano passado.

A lei norte-americana "The Patient Self-Determination Act (PSDA)", de 1991, prevê três formas de se efetivar as diretrizes antecipadas, quais sejam: a) testamento vital "living will"; b) através de procurador regulamente investido e c) decisão ou ordem antecipada para o cuidado médico. (ALVES, 2013, p. 96/97)

A lei espanhola, de $n^{\circ} 41 / 2002$, em seu art. 11, trata das instruções prévias. Nesse texto "uma pessoa maior de idade, capaz e livre, pode manifestar antecipadamente sua vontade, como o objetivo de que essa vontade se cumpra no momento em que a pessoa se encontre em uma situação em que não seja capaz de expressar esta vontade pessoalmente.” (ALVES, 2013, p. 98) A legislação espanhola também prevê a possibilidade do mandato duradouro.

$\mathrm{Na}$ Itália, tramita projeto de lei denominado testamento biológico. O fundamento jurídico dessa legislação é o art. 32 da Constituição italiana, preconizando que ninguém pode ser obrigado a um determinado tratamento sanitário, a não ser por disposição de lei. (ALVES, 2013, p. 100)

A lei uruguaia $n^{\circ} 18.473 / 2009$ fixa que o paciente pode se opor a determinados tratamentos médicos desde que de forma voluntária e consciente. Aí a antecipação de vontade pode ser feita por meio de escritura pública, ata notarial ou documento particular assinado pelo paciente e por duas testemunhas.

A lei holandesa é complexa, mas traz em seu nome as possibilidades de exercício da autonomia naquele Estado: "Lei de 12 de abril de 2001, relativa ao Término da Vida sob Solicitação e Suicídio Assistido e alteração do Código Penal e da Lei de Entrega do Corpo”.

Essa lei não faz menção expressa ao termo eutanásia que continua sendo ilícito criminal, mas os médicos obtiveram uma exclusão da ilicitude se a eutanásia for praticada conforme determinado, que só se aplica aos médicos. A justificativa para a eutanásia é o estado de necessidade psicológico.

\footnotetext{
1 Reportagem disponível no seguinte endereço eletrônico: <https://noticias.uol.com.br/ciencia/ultimasnoticias/afp/2018/05/07/cientista-de-104-anos-que-pediu-morte-assistida-vai-tomar-sedativo-cair-no-sono-emorrer-em-1-minuto.htm>. Acesso em 14 mai. 2018
} 
Na forma legal, a execução da morte, por meio da eutanásia, deve ser comunicada ao Instituto Médico Legal daquele País.

Para que a prática da eutanásia não seja considerada ilícita, devem ser observados os seguintes procedimentos:

a) médico deve estar seguro de que se trata de solicitação voluntária e pensada do paciente;

b) o paciente deve estar consciente de sua situação;

c) expressa conclusão de que não havia outra solução ou saída para o paciente; e

d) consulta a outro médico independente.

Sob o ponto de vista etário, também na Holanda, há três formas de eutanásia:

a) paciente com mais de 18 anos e que não pode expressar sua vontade, mas que deixou declaração autorizando a eutanásia;

b) paciente entre 16 e 18 anos que solicitou a eutanásia, desde que os pais tenham participado da decisão;

c) paciente entre 12 e 16 anos, desde que os pais tenham concordado com a eutanásia.

A lei holandesa ainda trata das Comissões Regionais de Verificação do Término da Vida sob Solicitação e Suicídio Assistido. É sua parte mais complexa.

As Comissões são órgãos públicos que têm por objetivo verificar se a eutanásia foi praticada de acordo com a lei, compostas por número ímpar de membros, sendo um jurista, um médico e um especialista em ética.

O papel do médico legista na Holanda é verificar se a eutanásia foi ou não praticada de acordo com a lei. Se praticada de forma legal, o médico legista pede autorização ao Procurador da Coroa para se proceder ao enterro ou cremação. Se o médico que praticou a eutanásia não tiver observado a legislação, tal fato será comunicado ao Procurador da Coroa.

Esse órgão fiscal, pelo Procurador da Coroa, se concluir que o médico não observou a legislação, dará início às investigações, com comunicação ao Instituto Médico Legal e à Comissão Regional de Verificação.

A Comissão Regional concluirá se o médico agiu corretamente, hipótese em que a decisão não é levada ao conhecimento do Ministério Público, mas se houver dúvida por parte da Comissão, o médico poderá ser processado criminalmente.

\subsubsection{A referência}

Evidentemente que sem esgotar a legislação havida em outros Países como Bélgica, França, Inglaterra, que também fazem referência à eutanásia, diretivas antecipadas e institutos 
similares, já se pode constatar que o ordenamento brasileiro é restritivo e não homenageia a autonomia de forma tão ampla como se vê pelo mundo.

Especialmente com apoio na legislação holandesa, é possível entrever outros paradigmas, em que a dignidade e a autonomia ganham vazão a ponto de ensejar relativização e renúncia do direito à vida, permitindo influxos às ofertas de modificação da realidade brasileira.

Como posto, o ordenamento brasileiro não homenageia a autonomia do paciente e nem lhe oportuniza a chance de escolher morrer com dignidade.

Com efeito, salvo as aqui referidas Resoluções do Conselho Federal de Medicina e a legislação aplicável às diretivas antecipadas, não há leis que estampem um diálogo franco e aberto com a comunidade, acerca da possibilidade de escolher como e quando morrer, revelando o tratamento do assunto sob a conjugação do binômio autonomia-dignidade.

Certamente, consoante preciosa lição de Ingo Wolfgang Sarlet, que:

No outro extremo da vida, merecem atenção diversas hipóteses que envolvam a atribuição da titularidade de direitos fundamentais àqueles que se encontram, pelas mais diversas razões, em situações limítrofes, como é o caso da manutenção artificial da vida, da capacidade de ser titular de direitos (e de quais direitos) nos casos de demência e senilidade aguda, onde a falta de consciência até mesmo de eventuais violações da dignidade e da própria condição pessoa, acaba, tal qual em outras hipóteses, implicando a discussão a respeito de um direito a uma morte digna e, em termos gerais, guarda relação íntima com todo o debate em torno das diversas formas de eutanásia e suicídio assistido. (SARLET, 2015, p. 229)

Essa atenção deve ser dada à titularidade do direito fundamental em exame, porque não sem razão, como ressaltou o Ministro Luiz Fux, no Superior Tribunal de Justiça, julgando o Recurso Especial n ${ }^{\circ} 802.435$, originário do Estado de Pernambuco, acórdão prolatado em sessão de 19 de outubro de 2006:

(...)

10. Deveras, a dignidade humana retrata-se, na visão Kantiana, na autodeterminação; na vontade livre daqueles que usufruem de uma vivência sadia. É de se indagar, qual a aptidão de um cidadão para o exercício de sua dignidade se tanto quanto experimentou foi uma "morte em vida", que se caracterizou pela supressão ilegítima de sua liberdade, de sua integridade moral e física e de sua inteireza humana?

11. Anote-se, ademais, retratar a lide um dos mais expressivos atentados aos direitos fundamentais da pessoa humana. Sob esse enfoque temos assentado que "a exigibillidade a qualquer tempo dos consectários às violações dos direitos humanos decorre do princípio de que o reconhecimento da dignidade humana é o fundamento da liberdade, da justiça e da paz, razão por que a Declaração Universal inaugura seu regramento superior estabelecendo no art. $1^{\circ}$ que 'todos os homens nascem livres e iguais em dignidade e direitos'. Deflui da Constituição federal que a dignidade da pessoa humana é premissa inarredável de qualquer sistema de direito que afirme a existência, no seu corpo de normas, dos denominados direitos fundamentais e os 
efetive em nome da promessa da inafastabilidade da jurisdição, marcando a relação umbilical entre os direitos humanos e o direito processual.

(...) (BRASIL, 2016, online)

No derradeiro trecho do julgado colacionado avulta a indagação acerca da possibilidade de fazer valer o direito fundamental de pôr fim à vida, pelo órgão constitucional encarregado de dirimir os litígios, colocando o Judiciário no centro do debate aqui travado muito embora este precedente trate da reparação de danos causados pela prisão injusta. Mas o raciocínio havido, para possibilitar a conclusão, é bastante oportuno para as provocações do presente trabalho.

Em situação próxima, que também tratou do direito à vida e à dignidade, o Supremo Tribunal Federal brasileiro julgou a ADPF $n^{0}$ 54, sob relatoria do Ministro Marco Aurélio, acórdão prolatado em sessão de 11 de abril de 2012, dizendo, em suma, que

\footnotetext{
(...) a questão posta sob julgamento é única: saber se a tipificação penal da interrupção da gravidez de feto anencéfalo coaduna-se com a Constituição, notadamente com os preceitos que garantem o Estado laico, a dignidade da pessoa humana, o direito à vida e a proteção da autonomia, da liberdade, da privacidade e da saúde.

(...) a resposta é desenganadamente negativa.
}

Transpondo para igual raciocínio o tema aqui tratado, de renúncia ao direito fundamental à vida, em exercício franco e seguro da autonomia e da dignidade da pessoa, não haveria que se impor empecilhos ao seu exercício, ainda que na ausência regra expressa.

É dizer: desde que em suscitação da defesa de preceito fundamental, cabe reivindicar eutanásia e ao suicídio assistido o mesmo tratamento dado à antecipação terapêutica do feto anencéfalo, como feito na $\mathrm{ADPF} \mathrm{n}^{\circ} 54$, supra colacionada porque os princípios invocados são os mesmos.

\section{Conclusão}

Os institutos jurídicos sofrem transformações, ocasionadas por múltiplos fatores que acompanham os avanços e retrocessos das relações humanas, e que influenciam o Direito, como se tem com a vida, que é indiscutível direito fundamental, do qual se poderia dispor.

Porém, o término da vida são situações cujas respostas não se encontram só na ciência do direito, mas também na medicina e na religião, embora num Estado lácio não se admita que possa realizar filtros sobre políticas públicas voltadas à implementação de direitos fundamentais. 
A Constituição Federal consagra a dignidade da pessoa humana como um de seus fundamentos, na norma do artigo $1^{\circ}$, III, inerente a todas as pessoas humanas, independentemente de credo ou condição social.

Noutro ângulo, autonomia está relacionada à ideia de liberdade, que, numa sociedade livre é fundamento, conforme se prevê para o Brasil, no art. $3^{\circ}$, I, da Constituição.

Por isso mesmo a autonomia deve ser observada em todas as fases da vida, inclusive naquela terminal, dos pacientes de doenças graves ou mesmo pelo decurso do tempo.

A despeito das divergências na conceituação da eutanásia, suicídio assistido, ortotanásia e distanásia, é fato base comum que permite a compreensão desses institutos e seus contornos jurídicos.

Os negócios jurídicos denominados testamento vital e mandato duradouro, mis exatamente o primeiro, não é a nomenclatura mais adequada, eis que se faz "inter vivos" e aquele que lhe dá o primeiro nome é negócio jurídico "causa mortis".

Superadas os questionados conceitos, a legislação brasileira sobre diretivas antecipadas é relativamente moderna, comparando-se outros sistemas jurídicos.

O mesmo não se pode dizer da eutanásia e do suicídio assistido, enfatizando que a Holanda apresenta modelo a ser seguido, embora não se tenha esgotado a comparação.

De toda sorte, arrematando, se pode concluir que, no Brasil não se admite a renúncia ao direito fundamental à vida em todas as hipóteses, ainda não oportunizando debate mais franco e sem preconceitos, acerca das práticas pelo mundo.

Malgrado isso, há importantes decisões nos tribunais superiores que já apontam para abertura da interpretação do direito fundamental em espeque, apresentando nova compreensão e releitura do sisudo e atrasado modelo de concentração e controle estatal sobre a vida e morte das pessoas.

\section{Referências bibliográficas}

ALBUQUERQUE, Roberto Chacon de. A lei relativa ao término da vida sob solicitação e suicídio assistido e constituição holandesa. Revista CEJ: (Brasília), Brasília, v. 13, n. 47, p. 108-117, out. 2009. 
ALVES, Cristiane Avancini. Diretivas antecipadas de vontade e testamento vital: considerações sobre linguagem e fim da vida. Revista jurídica (Porto Alegre), Porto Alegre, RS, v. 61, n. 427, 2013.

ASCENSÃO, José de Oliveira. O fundamento do direito: entre o direito natural e a dignidade da pessoa. In: SÁ, Maria de Fátima Freire; MOUREIRA, Diogo Luna; ALMEIDA, Renata Barbosa de. Direito privado revisitações. Belo Horizonte: Arraes, 2013.

AZEVEDO, Francisco Ferreira dos Santos. Dicionário analógico da língua portuguesa: idéias afins/thesaurus, $2^{\mathrm{a}}$ ed. atual. e rev. Rio de Janeiro: Lexikon, 2010.

BONTEMPO, Tiago Vieira. A ortotanasia e direito de morrer com dignidade: uma análise constitucional. Revista Síntese Direito de Família, v. 13, n. 68, p. 75-92, out./nov. 2011.

CRUZ, Elisa Costa. Autonomia do processo de morrer: as diretivas antecipadas como concretização da dignidade da pessoa humana. Revista Síntese de Direito de Família, Porto Alegre, v. 15, n. 80, p. 44-59, out 2013.

DADALTO, Luciana. Aspectos registrais das diretivas antecipadas de vontade. Revista Síntese Direito de Família, Porto Alegre, v. 15, n. 80, p. 60-69, out. 2013.

ESTÉFANI, Rafawl Junqueira; DÍAZ, F. Javier de la Torre. Bioética, teologia moral y sociedade. Comillas: Madrid, 2014.

FIGUEIREDO, Ricardo Vergueiro. Da participação em suicídio. Del Rey: Belo Horizonte: 2001.

FIÚZA, César. Direito civil curso completo. $12^{\mathrm{a}}$ ed. rev, atual e ampl. Belo Horizonte: Del Rey, 2008.

RECUERO, José Ramón. La eutanásia em la encrucijada. El sentido de la vida y de la muerte, Madrid: Biblioteca Nueva, 2004. 
RUGER, André; RODRIGUES, Renata de Lima. Autonomia como princípio jurídico estrutural. In: FÍÚZA, César; SÁ, Maria de Fátima Freire de; NAVES, Bruno Torquato de Oliveira (Coord). Direito civil da autonomia privada nas situações jurídicas patrimoniais e existências. Belo Horizonte: Del Rey, 2007.

SÁDABA, Javier. Princípios de bioética laica. Gedisa: Barcelona, 2004.

SÁ, Maria de Fátima Freire de; NAVES, Bruno Torquato de Oliveira. Manual de biodireito, $2^{\mathrm{a}}$ ed. Del Rey: Belo Horizonte, 2011.

SÁ, Maria de Fátima Freire de; MOUREIRA, Diogo Luna. Autonomia para morrer.

Eutanásia, suicídio assistido e directivas antecipadas de vontade. Del Rey: Belo Horizonte, 2012.

SARLET, Ingo Wolfgang. A eficácia dos direitos fundamentais. $12^{\mathrm{a}}$ ed. Porto Alegre: Livraria do Advogado Editora, 2015.

SIDOU, J. M. Othon. Dicionário jurídico. $10^{\mathrm{a}}$ ed. ver., atual., ampl. Rio de Janeiro: Forense, 2009. 


\title{
BULLYING E DANO MORAL: A PROBLEMÁTICA DA RESPONSABILIDADE CIVIL DA ESCOLA PARTICULAR
}

Fabrício Veiga Costa

Universidade de Itaúna

Denise Maria Soares

Universidade de Itaúna

\begin{abstract}
Resumo
Investiga-se a responsabilidade civil por dano moral da escola particular pela prática de bullying, condutas que reproduzem a violência em face da vítima no âmbito escolar. A escolha do tema justifica-se pela atualidade e relevância. A omissão da escola gera ilicitude e a indenização em razão da ofensa de direitos da vítima. A Lei 8078/90 estabelece que a responsabilidade civil da escola é objetiva, bastando comprovar a ilicitude, dano e nexo causal. Pela pesquisa bibliográfica e documental, e método dedutivo, concluiu que é possível a condenação da escola quando provados os requisitos legais.
\end{abstract}

Palavras-chave: Bullying, Dano Moral, Escola Particular,Responsabilidade Objetiva, Omissão da Escola.

\footnotetext{
Abstract/Resumen/Résumé

We investigate the civil responsibility for moral damages of the private school by the practice of bullying, behaviors that reproduce the violence in front of the victim in the school scope. The choice of theme is justified by the relevance and relevance. The omission of the school generates unlawfulness and compensation due to the offense of rights of the victim. Law $8078 / 90$ establishes that the civil responsibility of the school is objective, being sufficient to prove the unlawfulness, damage and causal nexus. By bibliographic and documentary research, and deductive method, concluded that it is possible to condemn the school when proven legal requirements.
} 
Keywords/Palabras-claves/Mots-clés: Bullying, Moral Damage, Private School, Objective Responsibility, School Omission.

\section{Introdução}

Constitui objetivo geral da presente pesquisa a investigação do fenômeno social da prática de bullying nas dependências da escola, de modo a analisar a possibilidade de responsabilidade civil por dano moral da instituição de ensino em razão de sua conduta omissiva. A escolha do tema justifica-se em razão de sua atualidade, relevância prática e teórica, além dos inúmeros episódios de bullying que ocorrem no espaço escolar, exigindose um entendimento transdisciplinar da temática, especialmente a abordagem no contexto da ciência do Direito.

Inicialmente, desenvolveu-se um estudo do bullying enquanto prática de violência moral, psicológica, física e sexual, delimitando-se o objeto da análise no contexto escolar. Ou seja, pretendeu-se evidenciar as formas mais utilizadas pelo agente na prática do bullying; as principais consequências trazidas para a vítima, além de demonstrar sua gênese e contexto em que normalmente ocorre. Em seguida, desenvolveu-se um estudo pontualmente no âmbito do direito, com o condão de justificar a aplicabilidade do Código de Defesa do Consumidor como fundamento regente do contrato de prestação de serviços educacionais.

Trata-se de contrato de adesão, com cláusulas especiais que denotam obrigações específicas assumidas pela instituição de ensino no que atine à prevenção e repressão da prática do bullying escolar. Nesse momento, demonstrou-se que constitui obrigação da escola criar "canais de denúncia" (ouvidoria) para permitir que vítimas e seus genitores comuniquem a escola sobre a ocorrência de bullying no âmbito institucional. A criação e execução de uma política de prevenção do bullying, mediante a confecção de materiais didáticos e realização de atividades pedagógicas constitui mais uma obrigação específica assumida contratualmente pela escola. Além disso, constitui obrigação legal da instituição de ensino se posicionar diante de casos pontuais de bullying que venham a ocorrer, reprimindo a conduta e minimizando o dano. A omissão da instituição de ensino diante dos casos de bullying constitui prática ilícita decorrente do descumprimento do contrato de prestação de serviços educacionais. Se tal ilicitude comprovadamente violar algum direito fundamental ou direito da personalidade da vítima, comprovando-se o nexo de causalidade, 
ficará demonstrado o dever de reparação.

Os critérios jurídicos de quantificação do dano moral relacionam-se com a extensão e os efeitos jurídicos da conduta lesiva na vida da vítima. Por isso, desenvolveu-se um estudo jurisprudencial nos tribunais brasileiros com o condão de demonstrar como a presente temática vem sendo tratada no âmbito jurisdicional.

Em meio a todas as proposições mencionadas, elaborou-se a pergunta problema: é juridicamente possível responsabilizar civilmente por danos morais a escola pela prática de bullying em suas dependências? É jurídico-legalmente admissível a aplicabilidade do Código de Defesa do Consumidor como referencial do contrato de prestação de serviços educacionais?

A realização da pesquisa bibliográfica e documental, realizada por meio de consultas a autores e documentos que abordam a temática proposta, viabilizou o estudo do tema na perspectiva analítica, comparativa, crítica e textual. A utilização do método dedutivo permitiu a delimitação do tema, partindo-se de uma concepção ampla, qual seja, o estudo do fenômeno social do bullying, especificando no estudo da responsabilidade civil por dano moral da escola.

\section{Compreendendo o Bullying: gênese, formas de praticar, consequências sofridas pela vítima e sua prática no âmbito escolar}

A palavra bullying vem da língua inglesa e remete ao significado de tirano, brigão ou valentão (BRASIL, Significados, 2018), ressaltando-se que no Brasil a respectiva terminologia remete ao sentido de zombar, ridicularizar, ofender, tripudiar, humilhar, intimidar, agredir e violentar a vítima, seja de forma moral, psicológica, física, sexual, pretendendo excluí-la, desmoralizá-la, tornando-a invisível aos olhos dos demais. "O termo bullying surgiu em 1973, através dos estudos de Olweus [...] para se referir a qualquer tipo de comportamento de agressão entre crianças, em que um ou vários indivíduos abusa intencionalmente da sua situação de superioridade sobre a vítima" (ESPINHEIRA; JÓLLUSKIN, 2009, p. 108). Na verdade, o bullying "é uma forma de afirmação de poder manifestada por agressões verbais (ameaças, zombarias), exclusão social e indiretas (espalhar boatos maldosos)" (BERNARDINI; MAIA, 2010, p. 100).

"De fato, a violência conceituada como bullying é observada nas escolas - e em outros ambientes como no trabalho, na casa da família, nas forças armadas, prisões, condomínios residenciais, clubes e asilos" (ANTUNES; ZUIN, 2008, p. 34). Tal afirmação se revela importante para esclarecer que o objeto de investigação proposto na presente pesquisa é a prática do bullying no âmbito escolar, de modo a analisar pontualmente a responsabilidade 
civil da escola em razão de condutas comprovadamente comissivas ou omissivas.

"No Brasil, diversas palavras e expressões tem sentido equivalentes ao bullying, como zoar, intimidar, humilhar, ameaçar, excluir, difamar e tantas outras. Tal comportamento se manifesta por atos repetidos de opressão, discriminação, intimidação, xingamentos, chacotas, tirania, agressão a pessoas ou grupos" (MALTA; SILVA; MELLO; MONTEIRO; SARDINHA; CRESPO; CARVALHO; SILVA; PORTO, 2010, p. 3066). Nessa perspectiva, bullying é um "termo que tem sido utilizado para designar uma prática perversa de humilhações sistemáticas de crianças e adolescentes no ambiente escolar” (PALÁCIOS; REGO, 2006, p. 3).

Na realidade, "o bullying ${ }^{1}$ é uma prática encontrada em todas as culturas, e acarreta sofrimento psíquico, diminuição da autoestima, isolamento, prejuízos no aprendizado e no desempenho acadêmico" (MOURA; CRUZ; QUEVEDO, 2011, p. 19). Verifica-se que "a prática do bullying se concentra na combinação entre a intimidação e a humilhação das pessoas" já que é vista como "uma forma de abuso psicológico, físico e social" (INÁCIA; OLIVEIRA, 2016, p. 90).

Importante ainda esclarecer que "o bullying se estabelece como uma violência onde há uma relação desigual de poder, isto é, o agressor tem poder sobre a vítima”, haja vista que o "muitas vezes se apresenta ser maior fisicamente que o alvo, intimidando ainda mais, fazendo com que o alvo se considere uma pessoa fraca, sem condições de acabar com essa situação" (GRILLO; SANTOS, 2015, p. 62). Essa violência estampada no espaço escolar pode ser explícita, simbólica, implícita, manifestando-se de diversas formas. O principal efeito de todo esse cenário violento é a coisificação da vítima, sua invisibilidade, exclusão, marginalidade. Reflexos no desempenho escolar são evidentes em razão do sofrimento causado naquele atingido diretamente por todos os efeitos dessas condutas.

A prática do bullying era até pouco tempo não muito conhecida entre as pessoas. "São atitudes agressivas, verbais ou físicas, intencionais e repetitivas, que ocorrem sem motivação evidente e são exercidas por um ou mais indivíduos, causando dor e angústia, com o objetivo de intimidar ou agredir outra pessoa sem ter a possibilidade ou capacidade de se defender", destacando-se que tais condutas são praticadas "dentro de uma relação desigual de forças ou poder" (BRASIL, Brasil Escola, 2018).

\footnotetext{
1 "O bullying, nomenclatura internacional pela qual é reconhecido um dos tipos de violência escolar, constitui um problema de saúde pública que requer investimentos e políticas que ampliem o foco sobre a questão, na medida em que é compreendido como objeto intersetorial de investigação e intervenção" (OLIVEIRA; SILVA; YOSHINAGA; SILVA, 2015, p.121).
} 
A condição desigual em que se encontra o sujeito vitimado pelas condutas violentas fortalece o agressor, que muitas vezes se utiliza de sua superioridade (maior força física) para ganhar espaço de reconhecimento entre seus pares. O agente da prática do bullying atua como protagonista de uma cena em que busca a condição de protagonista, procurando se auto afirmar, fortalecer-se diante do locus onde atua.

"O bullying passou a ser estudado cientificamente somente nas últimas décadas, tamanha a preocupação dos profissionais ao perceber a capacidade da agressão de gerar traumas, muitas vezes, irreversíveis nos envolvidos" (LEMOS, 2007, p.12). Nos dizeres de Olweus, citado por Susana Fonseca de Carvalhosa, Luísa Lima e Margarida Gaspar de Matos, na prática de bullying "um aluno está a ser provocado/vitimado quando ele ou ela está exposto, repetidamente ao longo do tempo, a ações negativas da parte de uma ou mais pessoas" (CARVALHOSA; LIMA; MATOS, 2002, p. 571).

"Entre esses comportamentos, podemos destacar agressões, assédios e ações desrespeitosas realizadas de maneira recorrente e intencional por parte dos agressores" (SILVA, 2015, p. 19). A ausência de razões específicas ou justificáveis marca tais condutas, considerando-se que o objetivo do agente é fazer prevalecer a vontade dos mais fortes sobre os mais fracos, mediante atitudes violentas e voltadas à humilhação, coisificação e ameaças contra as vítimas, causando-lhes muita dor e sofrimento. São condutas nas quais seus agentes buscam fortalecerem-se diante dos demais, objetivando a liderança do grupo através da construção do sentimento de temor do reverencial hábil a legitimá-lo como líder inato.

Entretanto, “o bullying, tal como conceituado, não é, de maneira alguma, uma simples manifestação de violência sem qualquer fator determinante" Tal contraponto se faz necessário com o objetivo de demonstrar que "o bullying se aproxima do conceito de preconceito, principalmente quando se reflete sobre fatores sociais que determinam os grupos-alvo, e sobre os indicativos da função psíquica para aqueles considerados como agressores" (ANTUNES; ZUIN, 2008, p. 36). "Estudos em vários países revelam que os comportamentos de bullying são comuns [...] e que pelo menos $15 \%$ dos estudantes na escola estão envolvidos nesses comportamentos" (CARVALHOSA; LIMA; MATOS, 2002, p. 572).

Inúmeras sãos as formas utilizadas para a prática do bullying, sejam elas verbal ("insultar, ofender, xingar, fazer zombações, colocar apelidos pejorativos, fazer piadas ofensivas, zoar”); físico e material (“bater, chutar, espancar, empurrar, ferir, beliscar, roubar, furtar ou destruir os pertences da vítima, atirar objetos contra a vítima”); psicológica e moral ("irritar, humilhar e ridicularizar, excluir, isolar, ignorar, desprezar ou fazer pouco caso, discriminar, aterrorizar e ameaçar, chantagear e intimidar, tiranizar, dominar, perseguir, 
difamar, passar bilhetes e desenhos de caráter ofensivo entre os colegas"); sexual ("abusar, violentar, assediar, insinuar") (SILVA, 2009, p. 19).

Dentre as consequências, pode-se destacar sintomas psicossomáticos (cefaleia, cansaço crônico, insônia, dificuldades de concentração, náuseas); transtorno do pânico ("o indivíduo é tomado por uma sensação enorme de medo e ansiedade, acompanhada de uma série de sintomas físicos"); fobia escolar (medo intenso de frequentar a escola); fobia social (timidez patológica, marcada por ansiedade excessiva e persistente, "com temor exacerbado de se sentiro centro das atenções ou de estar sendo julgado e avaliado negativamente"); transtorno de ansiedade generalizada (sensação de medo e insegurança persistente); depressão (sensação de tristeza, fraqueza ou baixo-astral); transtorno obsessivo-compulsivo (pensamentos sempre de natureza ruim, "intrusivos e recorrentes, causando muita ansiedade e sofrimento); esquizofrenia; suicídio; homicídio (SILVA, 2009, p. 23-31).

Sob o ponto de vista prático, o bullying acarreta "danos físicos, morais e materiais", haja vista "os apelidos cruéis e as gozações que magoam profundamente, as ameaças, as acusações injustas, a atuação de grupos que hostilizam a vida de muitos alunos" (BERNARDINI; MAIA, 2010, p. 101). A vítima do bullying acaba, muitas vezes, construindo um sentimento de culpa em razão de sua exclusão e medo, fatores esses que contribuem significativamente para seu adoecimento físico e mental.

"Em decorrência do bullying, a vítima pode desenvolver ou estimular pensamentos suicidas, isolamento, ansiedade, ira, indignação, rebaixamento ainda maior da autoestima, depressão, medo, traumas, angústia, vergonha, desejo de vingança, problemas psicossomáticos, marginalização, muito sofrimento e aversão à escola" (LEMOS, 2007, p.19).

"Os alunos que sofrem bullying, dependendo de suas características individuais e dos meios em que vivem principalmente os familiares, poderão não ultrapassar os traumas sofridos na escola" ou seja, "poderão quando adultos apresentar sentimentos negativos, especialmente com baixa autoestima, tornando-se indivíduos com sérios problemas de relacionamento", podendo “adquirir, também, comportamento hostil” (INÁCIA; OLIVEIRA, 2016, p. 90).

"A necessidade de se conhecer e estudar esse fenômeno dentro da escola se reforça na medida em que a contínua exposição ao bullying, nos mais variados tipos, pode acarretar às vítimas problemas comportamentais", especificamente "o estresse, a diminuição ou perda da autoestima, a ansiedade e depressão, o baixo rendimento escolar e até mesmo, em casos mais severos, o suicídio" MALTA; SILVA; MELLO; MONTEIRO; SARDINHA; CRESPO; CARVALHO; SILVA; PORTO, 2010, p. 3067).

A exposição direta e contínua da pessoa humana às práticas de condutas do agressoré 
hábil a contribuir significativamente para o fracasso ou evasão escolar. No momento em que a instituição de ensino se silencia, procurando demonstrar normalidade para não querer enfrentar o tema em seu ambiente, expõe a vítima, levando-a a enfrentar silenciosamente toda violência sofrida. "Um estudante é considerado vítima de bullying quando é repetidamente exposto a ações negativas de parte de um ou mais estudantes". Importante esclarecer que "estas ações negativas podem dar-se na forma de contato físico, abuso verbal ou com expressões ou gestos rudes". Por isso, "espalhar rumores e excluir a vítima de um grupo são formas comuns de violência" (MOURA; CRUZ; QUEVEDO, 2011, p. 20).

"O bullying tem efeitos negativos sobre as próprias crianças (vítimas e agressores) e sobre as crianças que observam estas práticas (observadores passivos)". Em razão disso, "estas se sentem muitas vezes incapazes de ajudar, o que provoca um sentimento de incapacidade e mal-estar, gerando sofrimento a estes observadores passivos" (PEREIRA; SILVA; NUNES, 2009,p. 458). O tema proposto é de relevância social, uma vez que não afeta apenas suas vítimas. Qualquer conduta violenta praticada no âmbito escolar tem desdobramentos que atingem diretamente sua vítima e indiretamente toda a coletividade. O bullying gera insegurança no outros alunos não atingidos diretamente pela conduta do agente, torna o ambiente escolar hostil, fomenta a prática de violência, gera a desigualdade, exclusão e marginalidade da vítima e de outros alunos que com ela se identificam ou se solidarizam.

"O bullying caracteriza-se por ser um problema mundial encontrado em todas as escolas, sejam elas privadas ou públicas, o que vem se expandindo nos últimos anos" Sabe-se que "a conduta bulling nas instituições de ensino tem sido um sério problema, pois gera um aumento significativo da propagação da violência entre os alunos" (REIS; OLIVEIRA, 2016, p. 64).

Tal fenômeno “[...] vem crescendo de forma epidêmica nas escolas e seus efeitos são traumatizantes aos alunos que presenciam e os que sofrem a ação, pois se trata de uma violência com caráter proposital e repetitivo" (GRILLO; SANTOS, 2015, p. 61). Identificar um comportamento como prática efetiva de bullying passa pela verificação de que "o mal causado a outrem não resulta de uma provocação", considerando-se que "as intimidações e a vitimação não são ocasionais", tendo em vista que "os agressores são mais fortes fisicamente e têmperfil violento e ameaçador, dificultando às vítimas a possibilidade de se defenderem ou pedirem auxílio" (ESPINHEIRA; JÓLLUSKIN, 2009, p. 108).

A ocorrência do bullying no âmbito escolar deve ser diretamente monitorada pela instituição de ensino, acompanhando-se as condutas omissivas e comissivas praticadas pelos professores ou demais funcionários de seu corpo administrativo, já que os mesmos possuem o 
dever de repelir, orientar, prevenir e observar qualquer conduta, postura ou atitude que caracteristicamente evidencie a prática de violência no âmbito escolar. "Não há bullying sem que haja um público a corresponder com as apelações de quem ironiza, age com sarcasmo e parece liderar aqueles que são expectadores” (TOGNETTA; VINHA, 2010, p. 452).

Fechar os olhos para tal fenômeno social é permitir que a escola se torne um espaço de prática reiterada da violência moral, física, psicológica e sexual, causando consequência danosas nas vítimas. "A agressividade na escola é um problema que pode afetar seriamente a habilidade das crianças progredirem a nível acadêmico e social” (ESPINHEIRA; JÓLLUSKIN, 2009, p. 109). Tais premissas teóricas apresentadas justificam-se porque "o bullying é um fenômeno de agressão velada, física, verbal ou psicológica, capaz de acarretar enorme prejuízo emocional, psicológico e social no indivíduo vitimizado" (LEMOS, 2007, p.9).

Compreender a temática proposta, sob a ótica transdisciplinar, é fundamental para o enfrentamento do debate da responsabilidade civil da escola. Estudos desenvolvidos por pesquisadores nas mais diversas áreas do conhecimento contribuíram para demonstrar a dimensão do tema, as aporias existentes. Evidencia-se, assim, que bullying começa na escola, gera reflexos na família, adoece a sociedade e, em razão disso, torna-se necessária a contribuição científica das proposições jurídico-legais, hábeis a esclarecer se a instituição de ensino pode ou não ser civilmente responsabilizada.

\section{Aplicabilidade do Código de Defesa do Consumidor no contrato de prestação de serviços educacionais, obrigações assumidas pela instituição e a responsabilidade civil objetiva da escola}

Em 11 de setembro de 1990 foi aprovada a Lei 8.078, denominado Código de Defesa do Consumidor, atendendo a previsão constitucional de que a defesa do consumidor é um direito fundamental a ser promovido pelo Estado (artigo 5., inciso XXXII da constituição brasileira de 1988), levando o legislador infraconstitucional a propor normas jurídicas hábeis a deixar claro que a proteção do consumidor não é uma questão apenas de cunho individual, mas sim, de natureza pública e interesse social.

Trata-se de microssistema jurídico fundado em inúmeros princípios que visam garantir a igualdade material dos consumidores, o direito de informação, presunção de boa-fé objetiva e, acima de tudo, o reconhecimento da vulnerabilidade e imposição de deveres aos fornecedores. "Os princípios da boa-fé objetiva e do equilíbrio das prestações reduzem a importância da vontade individual, em obediência aos princípios constitucionais da dignidade 
da pessoa humana, da solidariedade social e da igualdade substancial" (TEPEDINO, 2001, p. 11). Nos termos dispostos no artigo 2., da Lei 8078/90, considera-se consumidora toda pessoa física ou jurídica, nacional ou estrangeira, pública ou privada, que adquire bens ou serviços como destinatário final, ressaltando-se no parágrafo único que a coletividade poderá ser considerada consumidora por equiparação.

Já no artigo 3., do mesmo diploma legal, encontra-se a definição de fornecedor como sendo toda pessoa física ou jurídica, pública ou privada, nacional ou estrangeira, assim como os entes despersonalizados, que desenvolvem atividades de produção, montagem, criação, construção, transformação, importação, exportação, distribuição ou comercialização de produtos ou prestação de serviços (BRASIL, Lei 8078/90). "O CDC incide em toda relação que puder ser caracterizada como de consumo", considerando-se que "haverá relação jurídica de consumo sempre que se puder identificar num dos polos da relação o consumidor, no outro, o fornecedor, ambos transacionando produtos e serviços" (NUNES, 2009, p. 71).

A política nacional das relações de consumo, expressamente prevista no artigo 4., da Lei 8078/90, funda-se nos princípios da dignidade humana, consensualismo, boa-fé objetiva, direito fundamental à saúde, informação, igualdade material, transparência, reconhecimento da vulnerabilidade do consumidor no mercado de consumo. "A boa-fé objetiva, estabelecendo os deveres de comportamento que as partes devem seguir nas fases pré-contratual, contratual e pós-contratual, pode ser considerada [...] como sendo princípio geral de Direito" (AZEVEDO, 1995, p. 126).

A possibilidade de inversão do ônus da prova em benefício do consumidor, haja vista sua hipossuficiência diante do caso concreto; a interpretação de cláusulas contratuais de maneira mais favorável ao consumidor; o oferecimento de assistência jurídica integral e gratuita ao consumidor carente; estímulo à criação de associações de defesa e proteção do consumidor; a proteção contra publicidade enganosa, abusiva ou subliminar são algumas das proposições trazidas pelo legislador brasileiro (SILVA, 2005).

O contrato de prestação de serviços educacionais é regido pelo Código de Defesa do consumidor, haja vista que o aluno é o destinatário final do serviço educacional ora prestado. Trata-se de contrato de adesão, que possui cláusulas e obrigações específicas assumidas tanto pelo consumidor quanto pelo fornecedor. Considera-se de adesão o contrato no qual o consumidor recebe todas as cláusulas contratuais unilateralmente impostas pelo fornecedor, ressaltando-se que se deve garantir “a interpretação mais favorável ao aderente [...], já prevista no artigo 47 do Código de Defesa do Consumidor", além de "declarar nula a cláusula que implique renúncia antecipada do contratante aderente a direito resultante de natureza do 
negócio" (LÔBO, 2002, p. 15).

"Nos contratos de adesão a interpretação devia favorecer ao aderente", já que essa preocupação "surgiu em 1990 com o Código de Defesa do Consumidor, tocado pelos novos ventos que sopraram da Assembleia Constituinte, em virtude da retomada da plenitude democrática, e da Constituição cidadã de 1988" (PASQUALOTTO, 2002). A adesão às cláusulas contratuais unilateralmente impostas pelo fornecedor impede ao consumidor sua dialogicidade. A base de toda teoria geral dos contratos funda-se na possibilidade de os contratantes poderem discutir previamente as cláusulas do contrato, algo que se torna inviável nesse contexto, haja vista que "aderir é submeter-se ao contrato estabelecido e submeter a sua vontade protestando no íntimo contra a dura lei que lhe é imposta” (GOMES, 2006, p.10).

Pontualmente quanto ao tema objeto de análise no presente trabalho científico, verifica-se que a instituição de ensino assume a obrigação de garantir e oferecer um ambiente escolar saudável, seguro e que proporcione condições dignas ao pleno desenvolvimento da pessoa humana. Significa dizer que quanto ao bullying, caberá à instituição disponibilizar canais de denúncia, uma espécie de ouvidoria que proporcione ao discente ou sua família informar a ocorrência de qualquer conduta de violência moral, física, psicológica ocorrida no âmbito escolar.

Esse canal de interlocução é fundamental para permitir que casos de bullying tornemse conhecidos, permitindo-se que a instituição de ensino se posicione diante de cada caso concreto. No momento em que a escola deixa de oferecer ou disponibilizar esse canal de interlocução com o aluno ou seus genitores descumprirá cláusula do contrato de prestação implicitamente prevista no contrato.

Importante ressaltar que mesmo que não esteja expressamente prevista no contrato de prestação de serviços educacionais, tal cláusula que institui a obrigação de criação da ouvidoria, para assegurar o controle e monitoramento do bullying no ambiente escolar, decorre a interpretação e aplicação extensiva e sistemática dos princípios da boa-fé objetiva, dignidade humana e igualdade material. Tal obrigação é desdobramento do dever da instituição de ensino assegurar a segurança nas dependências da escola, entendendo-se a segurança numa perspectiva ampla, incluindo-se a integridade física, moral, psicológica e sexual dos alunos em suas dependências.

Outra obrigação assumida institucionalmente diz respeito à criação de uma política voltada à prevenção do bullying escolar. A confecção de materiais pedagógicos, realização de atividades didáticas de compreensão, existência e meios de prática do bullying constitui mais uma cláusula específica do contrato de prestação de serviços educacionais. Mesmo não estando 
explicitamente prevista no texto do contrato, tal obrigação decorre da interpretação sistemática dos princípios e direitos fundamentais que regem o Código de Defesa do Consumidor.

O envolvimento dos professores, alunos, família, sociedade e Estado assegura maior amplitude no debate e compreensão da temática, permitindo-se a realização de medidas efetivas de prevenção. Deixar de realizar campanhas educativas de prevenção do bullying escolar é omitir-se diante de problema que efetivamente existe no espaço escolar. Tal omissão expõe os alunos a uma vulnerabilidade mais explícita às diversas formas de violência que poderão ocorrer, constituindo ofensa direta aos direitos fundamentais das vítimas. Tem-se, diante de tal contexto, o descumprimento do contrato de prestação de serviços educacionais, destacandose tal conduta omissiva ilícita poderá ensejar o dever de indenizar, caso haja a comprovação do dano sofrido pela vítima.

Uma terceira obrigação contratual assumida pelas instituições de ensino diz respeito ao dever que a escola tem de se posicionar diante de casos pontuais de prática de bullying nas dependências do espaço escolar, apurando os fatos, punindo eventualmente o agente e garantindo a proteção da integridade da vítima. Em casos mais extremos, constitui dever da instituição comunicar autoridades e instituições competentes que zelam pelos direitos fundamentais de crianças e adolescentes, como é o caso do Conselho Tutelar e do Ministério Público.

Novamente é importante esclarecer que a última obrigação acima mencionada, mesmo que não esteja explicitamente prevista no contrato, deverá ser cumprida por ser considerada desdobramento da interpretação jurídico-principiológica do contrato de prestação de serviços educacionai regido pelo Código de Defesa do Consumidor.

A responsabilidade civil da instituição de ensino decorrerá de condutas ilícitas, omissivas ou comissivas, comprovadamente praticadas em face do aluno (consumidor). Para isso, é fundamental provar que tal ilicitude decorre do descumprimento do contrato de prestação de serviços educacionais quanto à obrigação assumida pela instituição. No momento em que a instituição de ensino é omissa quanto ao cumprimento das obrigações acima mencionadas, surge a possibilidade de discussão da responsabilidade civil pelos danos causados à vítima.

O entendimento dos requisitos legais da responsabilidade civil objetiva éfundamental à compreensão da temática apresentada. A comprovação da conduta ilícita, dano e nexo de causalidade são suficientes a ensejar a responsabilidade civil da instituição de ensino, dispensando-se a demonstração da culpa do agente.

Quanto à ilicitude, sabe-se que a mesma decorre de condutas comissivas ou omissivas praticadas pela instituição privada de ensino (escola particular). A condutas comissivas podem 
ser observadas quando a escola fomenta o bullying em razão de alguma postura pedagógica adotada, como por exemplo, quando adota um posicionamento no sentido de repudiar discussões de identidade de gênero, deixando expostos, vulneráveis e em evidência crianças ou adolescentes transgêneros e homossexuais, sujeitando-os ao bullying escolar. A ilicitude decorrente de condutas omissivas é evidenciada quando a própria escola toma conhecimento da prática de bullying e não se posiciona, deixando a vítima desprotegida diante da violência sofrida no ambiente escolar.

O dano sofrido pela vítima pode ser de ordem material ou moral. Os prejuízos materiais são aquelas perdas que comprovadamente decorreram da conduta ilícita do agente, ou seja, quando a criança ou adolescente, por exemplo, adoece em razão da prática de bullying no ambiente da escola, cabendo ao agente indenizar as despesas referentes ao tratamento médico. Já a reparação na esfera moral ocorrerá quando ficar demonstrado que a conduta ilícita praticada violou algum direito fundamental ou direito da personalidade da vítima, conforme exposto a seguir.A comprovação do nexo de causalidade, dispensando-se a demonstração da culpa do agente, é fundamental para esclarecer que o dano sofrido pela vítima adveio da conduta ilícita praticada pelo agente, justificando a reparação civil como medida compensatória do prejuízo moral ou material sofrido.

A partir dessas premissas apresentadas, demonstrou-se que o Código de Defesa do Consumidor é aplicado ao contrato de prestação de serviços educacionais, considerando-se que o aluno é o destinatário final do serviço prestado pela escola. Em razão disso, torna-se juridicamente aplicável as diretrizes legais e principiológicas de tal diploma legislativo, como o princípio da boa-fé objetiva, interpretação mais favorável ao consumidor, direito de informação, igualdade material em razão da vulnerabilidade, acesso à justiça, inversão do ônus da prova em virtude da hipossuficiência do consumidor.

As peculiaridades que caracterizam o contrato de prestação de serviços educacionais asseguram ao aluno o direito de ter um ambiente escolar saudável, seguro e que o assegure o pleno desenvolvimento humano no contexto do princípio da dignidade humana. A prática do bullying no ambiente escolar denota a prática de condutas ilícitas comissivas ou omissivas pela instituição de ensino, assegurando-se à vítima o direito à reparação.

Quanto ao objeto específico da presente pesquisa, pretende-se evidenciar a responsabilidade civil por dano moral em razão do bullying praticado na escola, seus requisitos de configuração e os critérios jurídicos de quantificação. 


\section{Dano moral como ofensa a direitos fundamentais ou direitos da personalidade: requisitos legais e critérios jurídicos de quantificação}

“O dano moral não mais se restringe à dor, tristeza e sofrimento, estendendo a sua tutela a todos os bens personalíssimos [...], razão pela qual revela-se mais apropriado chamálo de dano imaterial ou não patrimonial, como ocorre no direito português" (CAVALIERI FILHO, 2009, p. 81). De forma expressa, o texto da constituição brasileira de 1988 estabelece no artigo 5., inciso $\mathrm{X}$, o direito à indenização por dano moral ou material, decorrente da violação do direito à intimidade, vida privada, honra e imagem das pessoas.

O dano moral, “à luz da Constituição vigente, nada mais é do que agressão à dignidade humana". Nesse sentido, "só deve ser refutado como dano moral a dor, vexame, sofrimento ou humilhação que, fugindo à normalidade, interfira intensamente no comportamento psicológico do indivíduo, causando-lhe aflições, angústia e desequilíbrio em seu bem-estar"(CAVALIERI FILHO, 2009, p. 83).

Nos dizeres de Yussef Said Cahali, o dano moral "é a privação ou diminuição daqueles bens que tem um valor precípuo na vida do homem e que são a paz, a tranquilidade de espírito, a liberdade individual, a integridade individual, a integridade física, a honra e os demais sagrados afetos". Trata-se de "dano que afeta a parte social do patrimônio moral (honra, reputação) e dano que molesta a parte afetiva do patrimônio moral (dor, tristeza, saudade [...]), dano moral que prova direta ou indiretamente dano patrimonial” (CAHALI, 1998, p. 20)

O dano moral exige a comprovação da ilicitude do agente (contratual ou extracontratual), seja comissiva ou omissiva, dolosa ou culposa, praticada contrariamente aos direitos fundamentais ou direitos da personalidade da vítima. Pode ser juridicamente compreendido como uma ofensa aos atributos existenciais da vítima, cujos efeitos normalmente causam dor, sofrimento, angústia ou desordem física ou psicológica.

As proposições legislativas que regulam os direitos fundamentais e os direitos da personalidade protegem o patrimônio imaterial da pessoa humana, como a liberdade, igualdade, nome, vida, integridade (física, moral, educacional, psíquica, física, motora). O dano moral in re ipsa, também denominado de dano moral presumido, será indenizável independentemente da comprovação do sofrimento da vítima, como é o caso, por exemplo, da negativação indevida do nome de uma pessoa nos cadastros de registro de crédito.

A ofensa à honra objetiva ou subjetiva; violação de direitos fundamentais, como a vida, liberdade, igualdade, dignidade humana, princípio da não discriminação; condutas ilícitas 
contrárias a direitos da personalidade, como nome, integridade física, moral e psicológica, autonomia privada, são hábeis a ensejar o direito à reparação civil por dano moral.

Os efeitos jurídicos de tais condutas ilícitas deverão se prolongar no tempo, ou seja, não podem ser instantâneos, insuficientes de causar desordem no exercício de outros direitos, incapaz de atentar contra a dignidade humana, qualquer outro direito fundamental ou direito da personalidade. Nesses casos, a vítima não terá direito à reparação, considerando-se que não constitui a prática de dano moral, mas sim, o mero aborrecimento, insusceptível de reparação civil. "Mero dissabor, aborrecimento, mágoa, irritação ou sensibilidade exacerbada estão fora da órbita do dano moral", pois são situações que "não são intensas e duradouras, a ponto de romper o equilíbrio psicológico do indivíduo" (CAVALIERI FILHO, 2009, p. 83-84).

“A indenização por dano moral não visa ressarcir os prejuízos morais e psíquicos”, tendo em vista que seu propósito é "compensar toda a dor, sofrimento íntimo e angústia que atingem a vítima da violência, assim como visa proporcionar para o autor da violência uma perda patrimonial como forma de punição pelo ato ilícito cometido, impedindo que pratique novamente a conduta ilícita e antijurídica" (NASCIMENTO; ALKIMIN, 2010, p. 2817).

Nos dizeres de Maria Helena Diniz, “o dano moral, no sentido jurídico não é a dor, a angústia, ou qualquer outro sentimento negativo experimentado por uma pessoa, mas sim uma lesão que legitima a vítima e os interessados reclamarem uma indenização pecuniária, no sentido de atenuar, em parte, as consequências da lesão jurídica por eles sofridos” (DINIZ, 1998, p. 82).

A quantificação do dano moral passa pela análise da extensão fática e jurídica dos efeitos da conduta ilícita do agente contrariamente aos direitos fundamentais ou direitos da personalidade da vítima. Deve-se averiguar os reflexos dessa ilicitude no contexto imaterial do sujeito afetado, qual a dimensão da desordem causada na vida da pessoa humana, a intensidade da ofensa, os desdobramentos na esfera a intimidade, honra e subjetividade. A análise casuística e pontual das provas produzidas pelo demandante é imprescindível à quantificação da condenação.

"Cabe ao juiz, de acordo com seu prudente arbítrio, atentando para a repercussão do dano e a possibilidade econômica do ofensor, estimar uma quantia a título de reparação pelo dano moral" (CAVALIERI FILHO, 2009, p.91). Essa liberdade do julgador em quantificar o dano moral é regrada pelas provas produzidas nos autos, hábeis a esclarecer a dimensão da conduta do agente na vida da vítima.

O entendimento da natureza jurídica do dano moral refletirá de forma direta na sua quantificação. A problemática da temática em tela é saber se a natureza jurídica é punitiva ou 
compensatório-pedagógica, ressaltando-se que no Brasil tem prevalecido o entendimento através do qual "o fundamento do dever de reparação do dano não reside no propósito de sancionar ou punir, mas no princípio de que o dano sofrido tem que ser reparado, sempre que possível, pelo responsável” (SILVA; CASTRO, 2011).

As divergências existentes com relação ao quantum indenizatório encontram-se vinculadas à própria natureza do dano moral no direito brasileiro, algo que gera instabilidade quanto à segurança jurídica das decisões judiciais proferidas. "Há autores que defendem a ideia do tabelamento dos danos morais, com o objetivo de colocar termo às divergências existentes nos tribunais". Para esses autores, "o tarifamento dos danos extrapatrimoniais subtrairia do magistrado a sua independência na valoração do quantum indenizatório, não atendendo aos preceitos normativos atualmente existentes no direito brasileiro e comparado" (REIS, 1998, p. 119-120).

Em contrapartida, a tarifação do dano moral acarreta a padronização dos casos, inviabilizando uma análise apurada dos detalhes, das peculiaridades que marcam cada demanda judicial. Dessa forma, ter-se-ia uma dimensão jurídica em que a capacidade financeira do ofensor e os efeitos jurídicos do dano na vida da vítima não seriam levados em consideração.

É nesse contexto propositivo que será abordada a problemática atinente ao dano moral decorrente do bullying, especificamente no que tange à responsabilidade civil objetiva de a escola indenizar a vítima que sofreu a violência (física, moral, psicológica ou sexual) no espaço escolar.

\subsection{Dano Moral decorrente do Bullying escolar e a responsabilidade civil objetiva da escola: um estudo doutrinário e jurisprudencial}

A responsabilidade civil objetiva da escola em indenizar vítima de prática de bullying em suas dependências exige a comprovação da conduta ilícita da escola (comissiva ou omissiva) que gerou dano à vítima (moral ou material).

"A consequência imediata do bullying é o dano moral, ou seja, aquele que se traduz em sofrimento humano em razão da lesão à dignidade e personalidade, cujo sofrimento não tem nenhuma ligação com perda de patrimônio ou perda pecuniária”. Tal proposição se justifica porque essa modalidade de dano “está relacionada à reputação da vítima, à honra, a sua imagem e autoridade, ao pudor e amor-próprio, à saúde e integridade física e psíquica, bens jurídicos que não possuem valor de mercado, todavia, valor subjetivo para cada indivíduo, posto que relacionados a atributos pessoais e individuais com projeção na sociedade" (NASCIMENTO; 
ALKIMIN, 2010, p. 2816).

O dano moral advém diretamente da omissão da escola, que deixa de oferecer um ambiente seguro, que garanta a proteção ampla da pessoa humana contra qualquer tipo de violência. Foi esse o entendimento preconizado pelo Tribunal de Justiça do Distrito Federal, para quem "a escola deve propiciar um ambiente seguro, voltado às práticas educacionais, a fim de garantir o saudável desenvolvimento cognitivo dos estudantes". No caso em tela, a instituição de ensino apelou da sentença condenatória por danos morais pagos a uma aluna, especificamente porque a escola não demonstrou ter envidado esforços para evitar a prática do bullying em suas dependências.

Como defesa, a escola suscitou a excludente da responsabilidade civil fundada em prática de ato de terceiro, além de ter alegado que tomou as providências possíveis para amenizar os danos sofridos pela estudante. A relatora do presente caso entendeu que a escola tem o dever de proporcionar um ambiente saudável aos seus alunos, ressaltando que quando a escola deixa de fiscalizar e apurar fatos ocorridos em suas dependências, permitindo-se a prática do bullying, fica caracterizada conduta negligente e prestação defeituosa do serviço, "na medida em que o ambiente escolar não ofereceu a segurança razoável que dele se podia esperar". A partir desses fundamentos, o Tribunal de Justiça do Distrito Federal deixou de reconhecer a excludente de responsabilidade civil por ato atribuído a terceiro e condenou a escola ao pagamento de indenização a título de danos morais em favor da estudante, pela violação dos seus direitos de personalidade (BRASIL, Tribunal de Justiça do Distrito Federal).

O Tribunal de Justiça do Mato Grosso do Sul, no processo de número 004216302.2011.8.12.0001, por unanimidade, os desembargadores da 1. Câmara Cível "desproveramo recurso interporto por uma instituição de ensino que recorreu da decisão de primeiro grau que a condenou ao pagamento por danos morais e materiais a uma ex-aluna". As alegações constantes na petição inicial fundam-se nas agressões física e psicológicas sofridas pela aluna por parte dos colegas, ressaltando-se a inércia da instituição de ensino em tomar providencias para evitar o minimizar o dano (BRASIL, Tribunal de Justiça do Mato Grosso do Sul).

A criança era vítima de agressões psicológicas e físicas por parte de seus colegas em razão de seu sobrepeso. Por isso, sua genitora foi à escola pedir explicações e cobrar providências cabíveis, mas diante da inércia da instituição de ensino, foi necessário transferir sua filha para uma outra escola. Tais agressões comprovadamente causaram danos à criança e em razão disso o juiz de primeira instância fixou danos morais em $\mathrm{R} \$ 10.000,00$ (dez mil reais), sendo $\mathrm{R} \$ 6.000,00$ (seis mil) para a filha menor e $\mathrm{R} \$ 4.000,00$ (quatro mil reais) para a mãe, 
além do valor de $\mathrm{R} \$ 1.072,00$ (mil e setenta e dois reais) a titulo de danos materiais e razão da troca de escola.

No julgamento do recurso de apelação proposto pela escola, o relator entendeu que os valores fixados a titulo de indenização por danos materiais e morais devem ser mantidos, por serem razoáveis e proporcionais, além de atender a função pedagógica da condenação (BRASIL, Tribunal de Justiça do Mato Grosso do Sul). O fundamento central da decisão proferida encontra-se na conduta omissiva da instituição de ensino, que inobstante as constantes reclamações por parte da mãe, a escola não demonstrou que dispôs de todos os meios necessários para promover a integração entre os alunos e a adequação da situação da menina.

A segunda câmara especial do Tribunal de Justiça do Estado de Rondônia, em um só processo, julgou três apelações cíveis envolvendo a prática de bullying dentro de uma escola municipal. O município de Pimenta Bueno foi condenado a indenizar por dano moral a estudante que sofreu bullying de outros estudantes dentro da escola do município. Durante o julgamento, foi reconhecido pelos desembargadores que a violência contra a estudante atingiu emocionalmente a mãe dele, e por isso ela também foi indenizada pelo município; a cada um foi para, a título de indenização por danos morais, a quantia de $\mathrm{R} \$ 20.000,00$ (vinte mil reais). A vítima tinha 9 anos de idade à época dos fatos, sofria constantes agressões físicas e verbais de 3 estudantes; a mãe comunicou a direção da escola, que nada fez para que o caso tivesse fim (BRASIL. Tribunal de Justiça de Rondônia).

\section{Conclusão}

A prática do bullying no âmbito escolar é um fenômeno social contemporâneo que coisifica pessoas, submetendo-as aos efeitos diretos da violência moral, psicológica, física e/ou sexual. O agressor se coloca em posição de superioridade diante da vítima, atentando contra seus direitos existenciais, colocando-a numa posição de subserviência que a impossibilite qualquer tipo de reação.

A escola tem a obrigação contratual de se posicionar diante da prática do bullying em suas dependências. O contrato de prestação de serviços educacionais é de adesão, regido pelo Código de Defesa do Consumidor e tem cláusulas especiais. Garantir a segurança no espaço escolar; resguardar a integridade física, moral, psicológica e sexual; oferecer "canais de denúncia" (ouvidoria) da prática do bullying; instituir política de prevenção da prática de bullying, mediante a confecção de materiais didáticos e a realização de atividades pedagógicas; posicionar-se diante de casos pontuais de bullying no ambiente escolar, reprimindo-o ou 
minimizando os danos são obrigações contratualmente assumidas pela instituição de ensino.

No momento em que a escola se omite quanto ao cumprimento de uma ou mais de suas obrigações contratuais pratica ato ilícito passível de indenização, quando demonstrada a ocorrência do dano. Significa dizer que quando a escola deixa de se posicionar diante de casos de bullying ocorridos dentro de suas dependências assume a responsabilidade pela prática dessa conduta ilícita omissiva.

O dano moral é uma construção jurídica que se concretiza quando condutas ilícitas, omissivas ou comissivas, atentam contra direitos fundamentais ou direitos da personalidade, devendo seus efeitos jurídicos se estenderem ao longo do tempo e causarem alteração substancial na vida da pessoa, de modo a demonstrar ofensa a sua dignidade. Sempre que a escola é omissa, faz vistas grossas e deixa de agir em caso de bullying ocorrido em seu espaço acaba expondo demasiadamente a vítima.

A comprovação dos requisitos legais da responsabilidade civil objetiva é suficiente para a condenação da escola a indenizar a vítima por danos morais em razão da prática do bullying. Nesse caso, tem-se a aplicabilidade do Código de Defesa do Consumidor, haja vista que o aluno é o destinatário final do contrato de prestação de serviços educacionais. A conduta ilícita consiste na omissão da instituição de ensino em prevenir, reprimir ou minimizar os danos decorrentes da ocorrência do bullying. O dano moral, nesse caso, concretiza-se mediante a demonstração de que a conduta ilícita do agente desencadeou ofensa a um ou mais direitos fundamentais ou direitos da personalidade, cujos efeitos jurídicos são suficientes para atentar contra a dignidade humana, além de alterar substancialmente a rotina de vida da vítima. A quantificação do valor do dano levará em consideração as peculiaridades do caso concreto e a comprovação dos efeitos jurídicos da conduta do agente na vida da vítima, devendo ter o condão pedagógico-compensatório.

\section{Referências bibliográficas}

ANTUNES, Deborah Christina; ZUIN, Antônio Álvaro Soares. Do bullying ao preconceito: os desafios da barbárie à educação. Psicologia e Sociedade, 20 (1), 2008, p. 33-42.

Disponível em http://www.redalyc.org/html/3093/309326454004/. Acesso em 20 jan. 2018.

AZEVEDO, Antônio Junqueira de. Responsabilidade pré-contratual no Código de Defesa do Consumidor: estudo comparativo com a responsabilidade pré-contratual no direito 
comum. Revista da Faculdade de Direito da Universidade de São Paulo, v.90, 1995, p. $121-132$.

Disponível em http://www.journals.usp.br/rfdusp/article/view/67292/69902. Acesso em 22 jan. 2018.

BERNARDINI, Cristina Helena; MAIA, Helenice. Bullying escolar: uma análise do discurso dos professores. Polêmica, v.9, n.2, abr.-jun., 2010, p.99-104.

BRASIL. Tribunal de Justiça do Distrito Federal e dos Territórios. Disponível em https://www.tjdft.jus.br/institucional/jurisprudencia/informativos/2016/informativo-dejurisprudencia-n-331/pratica-de-bullying-em-escola-2013-dano-moral-configurado. Acesso em 23 jan. 2018.

BRASIL. Tribunal de Justiça de Rondônia. Disponível em https://slmadv.jusbrasil.com.br/noticias/402337763/justica-de-rondonia-condenamunicipio-a- indenizar-aluno-por-sofrer-bullying-na-escola?ref=topic_feed. Acesso em 23 jan. 2018.

BRASIL. Tribunal de Justiça do Mato Grosso do Sul. Disponível em https://tjms.jusbrasil.com.br/noticias/458566658/crianca-que-sofria-bullying-na-escolaganha- indenizacao-por-danos-morais?ref=topic_feed. Acesso em 23 jan. 2018.

BRASIL. Lei 8078, de 11 de setembro de 1990. Disponível em http://www. planalto.gov.br/ccivil_03/leis/L8078.htm. Acesso em 22 jan. 2018.

BRASIL. Significados. Disponível em https://www.significados.com.br/bullying/. Acesso em 20 jan. 2018.

BRASIL. Brasil Escola. Disponível em http://brasilescola.uol.com.br/ sociologia/bullying.htm. Acesso em 20 jan. 2018.

CAHALI, Yussef Said. Dano Moral. 2.ed., São Paulo: Revista dos Tribunais 1998. 
CARVALHOSA, Susana Fonseca de; LIMA, Luísa; MATOS, Margarida Gaspar de. Bullying-a provocação/vitimação entre pares no contexto escolar português. Análise Psicológica. v.20, n.4, 2002. Disponível em http://publicacoes.ispa.pt/ publicacoes/index.php/ap/article/view/21/pdf. Acesso em 20 jan. 2018.

CAVALIERI FILHO, Sérgio. Programa de responsabilidade civil. 8.ed. São Paulo: Atlas, 2009.

DINIZ, Maria Helena. Curso de Direito Civil. São Paulo: Saraiva, 1998.

ESPINHEIRA, Filipa; JÓLLUSKIN, Glória. Violência e bullying na escola: um estudo exploratório no 5. ano de escolaridade. Revista da Faculdade de Ciências Humanas e Sociais. Porto: Edições Universidade Fernando Pessoa, 2009, p. 106-115. Disponível em http://bdigital.ufp.pt/bitstream/10284/1319/1/106-115_\%20FCHS06-14.pdf. Acesso em 20 jan. 2018.

GOMES, Rogério Zuel. A NOVA ORDEM CONTRATUAL: pós-modernidade, contratos de adesão, condições gerais de contratação, contratos relacionais e redes contratuais. Revista de Direito do Consumidor, v.58, 2006. Disponível em http://www.gomesrosskamp.adv.br/artigos/Artigo1.pdf. Acesso em 22 jan. 2018.

GRILLO, Mariana Aparecida; SANTOS, Ana Caroline Silva. Bullying na escola. Colloquium Humanarum, Presidente Prudente, v.12, n.3, p. 61-74, jul.-set., 2015. Disponível em http://revistas.unoeste.br/revistas/ojs/index.php/ch/article/view/1414/1540. Acesso em 20 jan. 2018.

INÁCIA, Maria; OLIVEIRA, Thiago Augusto Costa de. Bullying na escola. Revista dos Alunos de Educação Física, ano 3, 2016, p. 89-97. Disponível em http://www.nwk.edu.br/intro/wpcontent/uploads/2014/05/Educa\%C3\%A7\%C3\%A3o - F\%C3\%ADsica-s\%C3\%B3-falta-capa.pdf\#page=89. Acesso em 20 jan. 2018.

LEMOS, Anna Carolina Mendonça. Uma visão psicopedagógica do bullying escolar. Revista de Psicopedagogia, v.24, n. 73, São Paulo, 2007. Disponível em http://pepsic.bvsalud.org/scielo.php?script=sci_arttext\&pid=S0103-84862007000100009. 
Acesso em 20 jan. 2018.

LÔBO, Paulo Luiz Netto. Princípios sociais dos contratos no CDC e no Novo Código Civil. Revista Jurídica Unirondon, Cuiabá, 2002, p. 11-24. Disponível em https://s3.amazonaws.com/academia.edu.documents/31235998/revista_juridica_3p.pdf?A WSAccessKeyId=AKIAIWOWYYGZ2Y53UL3A\&Expires $=1516647634 \&$ Signature $=\mathrm{M}$ RjUtZv FVp3EFg02MoorV0h76k0\%3D\&response-contentdisposition $=$ inline $\% 3 \mathrm{~B} \% 20$ filename $\% 3$ Incursoes_psicanaliticas_para_pensar_a_r.pdf\#pa ge $=12$. Acesso em 22 jan. 2018.

MALTA, Deborah Carvalho; SILVA, Marta Angélica Iossi; MELLO, Flavia Carvalho Malta de; MONTEIRO, Rosane Aparecida; SARDINHA, Luciana Monteiro Vasconcelos; CRESPO, Claudio; CARVALHO, Mércia Gomes Oliveira de; SILVA, Marta Maria Alves da; PORTO, Denise Lopes. Bullying nas escolas brasileiras: resultados da Pesquisa Nacional de Saúde Escolar (PeNSE), 2009. Ciência e Saúde Coletiva, 15 (Supl,2), 2010, p. 3065-3076.

NASCIMENTO, Grasiele Augusta Ferreira; ALKIMIN, Maria Aparecida. Violência na escola: o bullying na relação aluno-professor e a responsabilidade jurídica. Anais do XIX Encontro Nacional do CONPEDI, realizado em Fortaleza, 2010. Disponível em http://www.publicadireito.com.br/conpedi/manaus/arquivos/anais/fortaleza/3776.pdf. Acesso em 22 jan. 2018.

MOURA, Danilo Rolim de; CRUZ, Ana Catarina Nova; QUEVEDO, Luciana de Ávila. Prevalência e características de escolares vítimas de bullying. Jornal de Pediatria, v.87, n.1, 2011. Disponível em http://www.redalyc.org/html/3997/399738181004/. Acesso em 20 jan. 2018.

NUNES, Luiz Antônio Rizzatto. Curso de direito do consumidor. 4.ed. São Paulo: 2009, p. 71 .

OLIVEIRA, Wanderlei Abadio de; SILVA, Jorge Luiz da; YOSHINAGA, Andréa Cristina Mariano; SILVA, Marta Angélica Iossi. Interfaces entre família e bullying escolar: uma revisão sistemática., Psico-USF, Bragança Paulista, v.20, n. 1, jan.-abr., 2015, p. 121-132. 
PALÁCIOS, Marisa; REGO, Sérgio. Bullying: mais uma epidemia invisível? Revista Brasileira de Educação Médica, Rio de Janeiro, v.30, n. 1, jan.-abr., 2006. Disponível em http://www.scielo.br/pdf/rbem/v30n1/v30n1a01. Acesso em 20 jan. 2018.

PASQUALOTTO, Adalberto. O Código de Defesa do Consumidor em face do Novo Código Civil. Disponível em http://tmp.mpce.mp.br/orgaos/CAOCC/dirConsumidor/artigos/Artigo.ConsumidorO.CDC.em.face.do.Novo.Codigo.Civil.pdf. Acesso em 22 jan. 2018.

PEREIRA, Beatriz; SILVA, Marta Iossi; NUNES, Berta. Descrever o bullying na escola: estudo de um agrupamento de escolas no interior de Portugal. Revista Diálogo e Educação, Curitiba, v.9, n.28, set-dez, 2009, p. 455-466. Disponível em http://www.redalyc.org/html/1891/189114443004/. Acesso em 20 jan. 2018.

REIS, Luiz Paulo de Lima dos; OLIVEIRA, Thiago Augusto Costa de. Bullying escolar: o estudo desta agressividade. Revista dos Alunos de Educação Física, ano 3, 2016, p. 63-69. Disponível em http://www.nwk.edu.br/intro/wpcontent/uploads/2014/05/Educa\%C3\%A7\%C3\%A3o-F\%C3\%ADsica-s\%C3\%B3-faltacapa.pdf\#page=89. Acesso em 20 jan. 2018.

REIS, Clayton. Avaliação do dano moral. Rio de janeiro: Editora Forense, 1998.

SILVA, Fernando Borges da. O CÓDIGO DE DEFESA DO CONSUMIDOR um microssistema eficiente? Disponível em https://jus.com.br/artigos/7564/o-codigo-dedefesa- do-consumidor. Acesso em 22 jan. 2018.

SILVA, Ana Beatriz Barbosa. BULLYING - mentes perigosas nas escolas. Como identificar e combater a violência e o preconceito na escola. São Paulo: Globo, 2015.

SILVA, Luzia Gomes da; CASTRO, Júlio Cezar da Silva. Natureza jurídica da responsabilidade civil por danos morais. In: Âmbito Jurídico, Rio Grande, XIV, n. 93, out 2011. Disponível em: $<$ http://www.ambitojuridico.com.br/site/index.php/?n_link=revista_artigos_leitura\&artigo_id=10438\&revista_c 
ad erno=7>. Acesso em 22 jan 2018.

TEPEDINO, Gustavo. O Código Civil, os chamados microssistemas e Constituição: premissas para uma reforma legislativa. Problemas de Direito Civil. Coordenação: Gustavo Tepedino, Rio de Janeiro: Renovar, 2001.

TOGNETTA, Luciene Regina Paulino; VINHA, Telma Pileggi. Até quando? Bullying na escola que prega a inclusão social. Educação, Santa Maria, v. 35, 2010, p. 449-464. Disponível em http://www.redalyc.org/html/1171/117116968007/. Acesso em 20 jan. 2018. 


\title{
ESTATUTO DA PESSOA COM DEFICIÊNCIA E AS NOVAS REGRAS DA INCAPACIDADE CIVIL
}

\author{
Ariolino Neres Sousa Junior \\ Faculdade Integrada Brasil Amazônia-FIBRA
}

\section{Resumo}

O tema em estudo se caracteriza como de importante relevância, objetivando analisar as novas regras da incapacidade civil, após o advento do Estatuto da Pessoa com Deficiência (Lei 13.146/15) que reformulou o conceito de incapacidade, diferenciando de deficiência. Metodologicamente, estabelece-se uma análise descritiva e comparativa entre os dispositivos legais da Constituição com os da legislação infraconstitucional, a fim de verificar quais artigos do Código Civil/2002 sofreram alterações em virtude da promulgação da Lei 13.146/15. Logo, as novas regras da incapacidade civil e o novo conceito de deficiência ajudaram fortalecer a Dignidade Humana da Pessoa com Deficiência e seus diretos constitucionais.

Palavras-chave: Pessoa com deficiência, Dignidade da pessoa humana, Incapacidade, Estatuto da pessoa com deficiência, Constituição.

\section{Abstract/Resumen/Résumé}

The subject under study is characterized as of important relevance, aiming to analyze the new rules of civil incapacity, after advent of Statute of Person with Disabilities (Law 13.146/15) which reformulated the concept of incapacity, differentiating from deficiency. Methodologically, a descriptive and comparative analysis is established between the legal provisions of the constitution with those of infraconstitutional legislation, checking which articles of the Civil Code/2002 have undergone change due to the promulgation of Law $13.146 / 15$. So, the new rules of civil incapacity and new concept of deficiency helped strengthen Human Dignity of the Person with Disabilities and their constitutional rights.

Keywords/Palabras-claves/Mots-clés: Person with disabilities, Human person dignity, Inability, Statute of the person with disabilities, Constitution. 


\section{Introdução}

A presente pesquisa é reflexo de uma preocupação acadêmica e pessoal que começara a se desenvolver a partir do inicio do curso de Direito, chegando até o momento atual. Nesse sentido, associar o estudo das pessoas com deficiência em relação às novas regras da incapacidade civil trazidas pelo Estatuto da Pessoa com Deficiência, ao mesmo tempo correlacionando tal Estatuto à ordem principiológica civil e constitucional se constitui como objetivo central da pesquisa que vem sendo debatido e analisado perante o vigente panorama sociojurídico nacional. Por outro lado, como justificativa primordial, é importante suscitar que grupos socialmente mais vulneráveis, como as mulheres, as populações afro descendentes e as demais populações socialmente excluídas, com destaque para as pessoas com deficiência, sempre foram vítimas, ao longo da história da humanidade, das atitudes discriminatórias praticadas pelos detentores do poder, isto é, o Estado, empregadores, grupos religiosos conservadores e extremistas, entre outros. Especificamente retratando as pessoas com deficiência, a atribuição de adjetivos pejorativos que consideravam como "serem inferiores", "inúteis", “inválidos", etc., sinalizava a prática da discriminação promovida pelos grupos dominantes do poder, cujo resultado foi promover o afastamento delas do convívio social, reduzindo-as, assim, a condições subumanas de vida.

Além disso, temas centrais como "incapacidades" e "deficiência" são extremamente importantes, a fim de se estabelecer uma salutar discussão entre ambas nomenclaturas visando valorizar a dignidade da pessoa humana e os direitos fundamentais das pessoas com deficiência em prol de sua inclusão social. Não se pode olvidar também que, atualmente no Brasil, tem-se observado um elevando número de pessoas com deficiência, conforme informa os dados da Secretaria dos Direitos Humanos em que cerca de 23,92\% da população tem algum tipo de "deficiência", e que cada vez mais se faz necessária a inclusão e a mudança de paradigmas acerca do termo "deficiência" como algo "inferior" e "diferente".

A discussão dos direitos fundamentais em prol das pessoas com deficiência recebeu especial tratamento legal após o Estatuto da Pessoa com Deficiência - Lei 13.146/2015, cuja origem é da "Convenção sobre os Direitos das Pessoas com Deficiência e seu Protocolo Facultativo", ratificada pelo Congresso Nacional por meio do Decreto Legislativo $\mathrm{n}^{\circ} 186$, de 9 de julho de 2008. Assim sendo, considerando o procedimento previsto no $\S 3^{\circ}$ do art. $5^{\circ}$ da

\footnotetext{
${ }^{1}$ Dados percentuais fornecidos pela Secretaria de Direitos Humanos, após estudo específico realizado, estando disponibilizando no endereço eletrônico: <https://www.sdh.gov.br/assuntos/pessoa-com-deficiencia/dadosestatisticos/pesquisas-demograficas em 22/01/2017>. Acesso em: 04 fev.2018.
} 
Constituição da República Federativa do Brasil, a Convenção passou a vigorar após a promulgação do Decreto $\mathrm{n}^{0} 6.949$, de 25 de agosto de 2009 .

Dessa forma, em prol do reconhecimento dos direitos fundamentais das pessoas com deficiência, a presente pesquisa suscita como problema saber quais os reflexos e implicações jurídicas que o Estatuto das Pessoas com Deficiência passou a proporcionar para o instituto do Direito Civil, especificamente para a regra da Incapacidade Civil?

Por outro lado, torna-se imperioso esclarecer que o tipo de pesquisa utilizado foi a bibliográfica por intermédio da investigação doutrinária relativa ao tema, a partir do uso de livros, artigos científicos e legislações específicas. Com isso, tem-se a finalidade de compreender e analisar, por intermédio de uma abordagem qualitativa, os motivos que têm levado para discussão acerca do Estatuto das Pessoas com Deficiência e suas implicações para as regras da incapacidade civil. Para auxiliar esse estudo, o método utilizado é o comparativo, cuja função é discutir e comparar importantes posicionamentos doutrinários relativos à temática central proposta.

\section{Incapacidade e deficiência: análises conceituais e históricas}

A pessoa natural é o sujeito nato de direito, com personalidade a ela atribuída. A personalidade é o atributo jurídico da pessoa que permite a esta ser reconhecida como ente de direito, e no direito brasileiro se adquire com nascimento com vida, na forma do art. $2^{\mathrm{a}}$ do $\mathrm{CC} / 02 .^{2}$

Aduz-se que o Direito brasileiro trata também da questão do nascituro, protegendo-o desde sua concepção. Além disso, o tema é extenso e controverso diante das teorias natalista e concepcionista, pois conforme menciona Venosa (2016, p. 144):

O fato de o nascituro ter proteção legal, podendo inclusive pedir alimentos, não deve levar a imaginar que tenha ele personalidade tal como a concede o ordenamento. Ou, sob outros termos, o fato de ter ele capacidade para alguns atos não significa que o ordenamento lhe atribui personalidade. Embora haja quem sufrague o contrário, tratase de uma situação que somente advém do nascimento com vida.

Considerando a opinião retro, verifica-se que há distinção entre "personalidade" e “capacidade", já que somente após o nascimento com vida que a "personalidade material” será deferida, ou seja, o direito de pleitear alimentos por intermédio de representatividade legal.

\footnotetext{
${ }^{2}$ Art. $2^{\mathrm{o}}$ - A personalidade civil da pessoa começa do nascimento com vida; mas a lei põe a salvo, desde a concepção, os direitos do nascituro.
} 
A personalidade gera um conjunto de direitos próprios atrelados à pessoa, sendo tais direitos inatos, vitalícios, extrapatrimoniais, passíveis de indenização, imprescritíveis e irrenunciáveis ${ }^{3}$. Nesse sentido, uma vez reconhecida a pessoa como ente de direito, pode exercer de forma plena todos os aspectos de sua personalidade, quais sejam morais, físicos e psíquicos, todos garantidos constitucionalmente e não excludentes entre si. É neste contexto que:

\begin{abstract}
A personalidade, se não se identifica com os direitos e com as obrigações jurídicas, constitui a precondição deles, ou seja, seu fundamento e pressuposto. Óbvio que, enquanto simples susceptibilidade de ser titular de direitos e obrigações, deve ser algo diferente destes; mas, para ser 'susceptibilidade', é ao mesmo tempo fundamento sem o qual os mesmos direitos e obrigações não podem subsistir. Não se pode ser sujeito de direitos e obrigações, se não se está revestido dessa susceptibilidade, ou da qualidade de pessoa. (CUPIS, 2004, p. 21)
\end{abstract}

Por outro lado, a capacidade pode ser definida como a aptidão genérica para praticar os atos da vida civil, ou seja, a possibilidade de manifestação de vontade com efeitos pessoais e patrimoniais na vida prática do emissor e do receptor da referida manifestação de vontade, logo é uma aptidão genérica para adquirir direitos e exercê-los. ${ }^{4}$ Destarte, as incapacidades reguladas no ordenamento civil são apenas as de exercício ou de fato, pois a capacidade de gozo é atribuída a todo ser humano.

A capacidade é de exercício ou de fato e restringe-se às questões que tem o necessário discernimento para prática dos atos da vida civil. A capacidade de direito refere-se à possibilidade de adquirir direitos e aptidões garantidas a todas as pessoas. Logo, faz-se necessário distinguir conceitos como" capacidade", "legitimidade" e "imputabilidade".

A capacidade é a aptidão para prática dos atos da vida civil, a exemplo "casar", "contratar em sentido amplo", "responder por seus atos na esfera da responsabilidade civil", dentre outros. A legitimidade é a capacidade específica para prática desses atos, como a “outorga uxória para venda de certos e determinados bens", a "disposição patrimonial entre ascendente e descendente e herdeiros entre si", a "representação em atos negociais", dentre outros. A imputabilidade é um conceito do direito penal, presente de forma clara no art.26 do Código Penal, in verbis: “Art. 26 - É isento de pena o agente que, por doença mental ou desenvolvimento mental incompleto ou retardado, era, ao tempo da ação ou da omissão,

\footnotetext{
${ }^{3}$ De acordo com a redação do Art. 11: Com exceção dos casos previstos em lei, os direitos da personalidade são intransmissíveis e irrenunciáveis, não podendo o seu exercício sofrer limitação voluntária.

${ }^{4}$ Entende-se que essa aptidão requer certas qualidades inerentes a pessoa, sem as quais a mesma não terá capacidade de fato. In: VENOSA, Silvio de Salvo. Op.cit., p. 144
} 
inteiramente incapaz de entender o caráter ilícito do fato ou de determinar-se de acordo com esse entendimento". 5 Além disso, importante considerar que:

Personalidade e capacidade completam-se, pois de nada valeria a personalidade sem a capacidade jurídica, que se ajusta ao conteúdo da personalidade na mesma e certa medida em que a utilização do direito integra a ideia de ser alguém titular dele". (GONÇALVES, 2016, p. 96)

Não se pode negar, conforme comentário retro, que "personalidade e capacidade" estão interligadas para a produção dos efeitos jurídicos na vida do sujeito de direito. Todavia, no que se referem às incapacidades, os atos jurídicos serão considerados nulos ou anuláveis, e este é um efeito extremamente relevante no âmbito civil, uma vez que gera consequências pessoais e patrimoniais, que vão desde a indenização até o desfazimento do negócio, sem olvidar os efeitos penais dos mesmos. Com isso, estabelecer critérios específicos para as incapacidades é delimitar os efeitos dos atos da vida civil do homem, interpretando de forma extensiva consoante a regra do art. $1^{\circ}$ do CC: "Toda pessoa é capaz de direitos e deveres na ordem civil". Este dispositivo informa que toda pessoa é capaz, podendo adquirir direitos e sendo sujeito de relação jurídica em sentido amplo, ainda que não possa discernir ou ter a clareza de suas escolhas.

A incapacidade decorre de fatores temporais e também limitações de ordem física, sendo que esta última não abrange o aspecto de limitação de funcionamento do corpo, mas sim de manifestação livre da vontade na expressão da mente. Contudo, é sempre bom lembrar que o Código Civil de 1916 foi elaborado sob a égide social de que a pessoa com deficiência deveria ser tratada como incapaz, visto que não mencionava nenhum procedimento e técnicas específicas para o aprimoramento da limitação física ou psíquica da pessoa com deficiência (SANTOS, 1987, p. 55).

Posteriormente, o Código Civil de 2002 passou a elencar o absolutamente incapaz e o relativamente incapaz, perante os dispositivos a seguir: Art. $3^{\mathfrak{o}}$ - São absolutamente incapazes de exercer pessoalmente os atos da vida civil: I - os menores de dezesseis anos; II - os que, por enfermidade ou deficiência mental, não tiverem o necessário discernimento para a prática desses atos; III - os que, mesmo por causa transitória, não puderem exprimir sua vontade. Art. $4^{\mathrm{O}}$ - São incapazes, relativamente a certos atos ou à maneira de os exercer: I - os maiores de dezesseis e menores de dezoito anos; II - os ébrios habituais, os viciados em tóxicos, e os que,

\footnotetext{
${ }^{5}$ Disponível em: < http://www.planalto.gov.br/ccivil_03/decreto-lei/Del2848compilado.htm>. Acesso em: 09 mar. 2018
} 
por deficiência mental, tenham o discernimento reduzido; III - os excepcionais, sem desenvolvimento mental completo. Assim, as hipóteses enumeradas se assemelham ao código de 1916, apesar de atualizadas quanto à linguagem, além de diferenciar os tipos de dificuldade de discernimento. Logo, o CC/02 avançou no sentido de elencar as novas hipóteses de pessoa com incapacidade relativa e absoluta em comparação ao código anterior.

\section{O estatuto da pessoa com deficiência perante a abordagem principiológica civil- constitucional}

A deficiência física e mental foi acolhida pelos Direitos Humanos com a devida relevância. Observa-se que os Direitos Humanos são universais e indivisíveis, pois, segundo Cristiano Chaves Farias (2016, p. 20):

Caracterizam-se os Direitos Humanos, pela universalidade e a indivisibilidade. É universal porque atinge todos os seres humanos, basta que alguém nasça, independentemente de ser branco ou negro, mulher ou homem, irrelevante sua condição econômica. E indivisível, pois se cria um vínculo entre os direitos civis e políticos aos culturais, econômicos e sociais.

No que se refere ao preconceito, este norteava o tratamento à pessoa com deficiência desde os primórdios da Humanidade, uma vez que tratava com intolerância aquelas pessoas, considerando-as como um castigo divino, como alguém subjugado e sem poder manifestar sua vontade (PIOVESAN, 2016). Entretanto, após o surgimento da Convenção Internacional sobre Direito da Pessoa com Deficiência começava uma nova era em prol da defesa dos direitos daquele público alvo, a partir do momento em que procurou reabilitar uma pessoa com deficiência no seio da sociedade, garantindo o respeito a sua independência e igualdade de seus direitos. Assim, a deficiência é um conceito em evolução e que resulta da interação entre pessoas com deficiência e as barreiras devidas às atitudes e ao ambiente que impedem a plena e efetiva participação daquelas pessoas na sociedade em igualdade de oportunidades com as demais pessoas (DINIZ, 2016).

Essa é a tônica do Estatuto da Pessoa com Deficiência, cuja preocupação do legislador visa garantir a proteção do Estatuto não apenas, por exemplo, a uma pessoa com deficiência sob a modalidade "física", mas também àquela que, embora preservado seu estado físico, apresenta algum problema de ordem “psicológica”, merecendo, da mesma forma, especial atenção do Estado. Importante frisar que em uma avaliação biopsicossocial há, neste caso, a junção desses dois aspectos na abordagem da pessoa com deficiência, superando-se, nessa linha 
de raciocínio, o simples modelo biológico que até então era o principal a ser seguido (FARIAS, 2016).

Diante da perspectiva biopsicossocial, importantes indagações são discutidas e analisadas no que tange à averiguação, por exemplo, como um menor incapaz e com deficiência deve ser tratado? "Incapacidade" e "Deficiência" é a mesma interpretação após o advento do Estatuto das Pessoas com Deficiência? Partindo desses questionamentos, se considerar o homem como ser dotado de razão é fundamental discuti-la em sua própria essência interpretativa, conforme assevera a filosofia kantiana em que mostra o homem como ser racional, que existe como fim em sim mesmo, e não simplesmente como meio. Corroborando com tal filosofia, José Afonso da Silva (2010, p. 38) reforça ao asseverar que:

\footnotetext{
Os seres desprovidos de razão têm um valor relativo e condicionado, o de meios, eis porque são chamados de coisas. (...) só o ser humano, o ser racional, é pessoa. Todo ser humano sem distinção é pessoa, ou seja, um ser espiritual que é, ao mesmo tempo, fonte e imputação de si próprio.
}

Considerando a opinião retro em que valoriza o ser humano e sua racionalidade, fazse necessário elencar os princípios do Direito e sua aplicabilidade, notadamente entender o direito civil-constitucional em sua função interpretativa. Sendo assim, há que se compreender atentamente o Código Civil de 2002 numa perspectiva civil-constitucional para se atribuir não só clausulas gerais, aqui realçadas por sua extraordinária importância no sistema, mas também todo corpo codificado em um significado coerente. Com isso, pretende-se transformar efetivamente a realidade, fortalecendo as relações jurídicas privadas, seguindo os ditames da solidariedade e justiça social em prol das pessoas com deficiência (TEPEDINO, 2013).

A partir da segunda metade do séc. XX e no Brasil particularmente com o advento da $\mathrm{CF} / 88$, surge o fenômeno da "Constitucionalização do Direito Civil", cuja finalidade é a sujeição das normas e institutos do próprio Direito Civil aos princípios e regras da Constituição. De fato, valores constitucionais como a "dignidade da pessoa humana", "solidariedade social" e "igualdade substancial" marcaram decisivamente a mudança do direito civil contemporâneo provocando uma despatrimonialização deste ramo do Direito, o que inevitavelmente levará à sua despersonalização, exigindo-se de todos uma releitura do Direito civil a partir das lentes da Constituição e em consonância com valores humanos (CUNHA JUNIOR, 2015).

Dessa forma, os princípios gerais do direito norteiam a produção e a interpretação das normas, haja vista que englobam importantes investigações sobre o sistema jurídico, recaindo 
sobre os subsistemas normativos, fáticos e valorativos concernentes à questão omissa que se deve solucionar, preenchendo as lacunas, podendo até penetrar, para tanto, no campo da Ciência do Direito, bem como da Filosofia Jurídica. Nesse sentido, os princípios gerais do direito não são preceitos de ordem ética, política, sociológica ou técnica, mas elementos componentes da própria ciência jurídica. Consoante defende Maria Helena Diniz (2016, p. 34): "São normas de valor genérico que orientam a compreensão do sistema jurídico, com sua aplicação e integração". Desta feita, a função dos princípios é propiciar uma interpretação mais adequada da norma, e nortear sua aplicabilidade. Dos princípios do direito civil, voltados, por exemplo, às pessoas com deficiência, destaca-se o "princípio da personalidade", presente de forma clara no Capítulo II artigos 11 a 21 do CC/02.

Segundo o "princípio da personalidade", a constitucionalização do direito civil importa na alteração do fundamento de validade de institutos tradicionais por meio da imposição de deveres extrapatrimoniais em normas constitucionais, com o desiderato de possibilitar a realização da personalidade (MORAES, 2015). Partindo desse entendimento, uma pessoa com deficiência, mas com relativa incapacidade civil, não deve ser tratada de forma indigna, tendo em vista que dignidade não é sinônimo de "capacidade". Destarte, o seu "status personae" e o seu "viver com dignidade" no seio da comunidade familiar ou social não se relaciona com sua "capacidade" mental ou intelectiva para exercer direitos, nem com apoio recebido de eventuais apoiadores, nem com a transferência de decisões.

Por outro lado, princípios como a "igualdade" e a "não discriminação" estão presentes no texto constitucional, sendo também mencionados na regra do art. $4^{\circ}$ do Estatuto da Pessoa com Deficiência ${ }^{6}$. Neste sentido, foi importante a análise feita pelo referido dispositivo legal, tendo em vista que buscou fortalecer o combate à negligência, ao abandono, discriminação, exploração, violência, tortura, crueldade, opressão e tratamento desumano ou degradante contra a pessoa com deficiência.

Outro fator preponderante é que o Estatuto da pessoa com deficiência objetivou dar relevância aos direitos fundamentais já garantidos constitucionalmente, quais sejam direito à vida, saúde, habilitação e reabilitação, educação, moradia, trabalho, assistência social, cultura, esporte, turismo, lazer e transporte. Com isso, fortalece o principio da igualdade por garantir a

\footnotetext{
${ }^{6}$ Art. 4o Toda pessoa com deficiência tem direito à igualdade de oportunidades com as demais pessoas e não sofrerá nenhuma espécie de discriminação. § 1 onsidera-se discriminação em razão da deficiência toda forma de distinção, restrição ou exclusão, por ação ou omissão, que tenha o propósito ou o efeito de prejudicar, impedir ou anular o reconhecimento ou o exercício dos direitos e das liberdades fundamentais de pessoa com deficiência, incluindo a recusa de adaptações razoáveis e de fornecimento de tecnologias assistivas.
} 
todas as pessoas com ou sem deficiência os mesmos direitos fundamentais ressaltados anteriormente, além do dever de dispensar tratamento equânime às pessoas (MELLO, 1998).

Ainda no que diz respeito ao princípio da igualdade, faz-se necessário aduzir que J.J. Gomes Canotilho (2002) explica que uma das funções dos direitos fundamentais ultimamente mais acentuada pela doutrina (sobretudo a doutrina norte-americana) é a que se pode chamar “função de não discriminação". Partindo dos direitos fundamentais garantidos pela norma constituição brasileira, o Estado deve garantir que os cidadãos sejam tratados como fundamentalmente iguais, sem quaisquer forma de discriminação perante sua condição sociocultural e biológica. Por esse motivo, o legislador pátrio pretendeu impedir, por exemplo, a discriminação contra os grupos vulneráveis, dentre os quais se encontra uma pessoa com deficiência comprovada. A meta principal é reconhecer que a pessoa com deficiência tenha sua cidadania respeitada, pois é sujeito de direito e merece respeito em prol da dignidade de sua pessoa humana (FARIAS, 2016).

Outro importante princípio atrelado à defesa dos direitos fundamentais das pessoas com deficiência é a "dignidade da pessoa humana". Conforme preleciona Flávio Tartuce (2006), o Estatuto das Pessoas com Deficiência homenageou a dignidade da pessoa humana, a partir do momento em que passou a valorizar e defender a pessoa com deficiência como verdadeiro sujeito de direito e que, ao mesmo tempo, deixasse de ser rotulada como ser "inferior" ou até mesmo generalizando como "incapaz" diante de todas as situações. Assim, a pessoa com deficiência passaria a ser considerada como sujeito plenamente capaz, ainda que haja a necessidade, em algumas ocasiões, de adoção de institutos assistenciais específicos, como a tomada de decisão apoiada e, extraordinariamente, a curatela, para a prática de atos na vida civil.

Por outro lado, o STF já se posicionou favoravelmente quanto ao reconhecimento de direitos no âmbito civil e constitucional em prol da dignidade das pessoas com deficiência, a exemplo de alguns de seus trechos infirmativos in verbis ${ }^{7}$ :

INFORMATIVO No 829 - TÍTULO: Direito à educação: ensino privado e acesso a pessoas com deficiência - PROCESSO ADI - 5357 ARTIGO. O Plenário, após converter em julgamento de mérito o exame de referendo de medida cautelar em ação direta de inconstitucionalidade - ajuizada em face do $\S 1^{\circ}$ do art. 28 e do "caput" do art. 30, ambos da Lei $13.146 / 2015$ - , deliberou, por maioria, julgar o pleito improcedente. Os dispositivos

\footnotetext{
${ }^{7}$ Decisões proferidas em sede de análise da Ação direta de inconstitucionalidade $\mathrm{n}^{0} 5.357 \mathrm{MC}$, pelo ministro relator Edson Fachin.
} 
impugnados tratam da obrigatoriedade das escolas privadas de oferecer atendimento educacional adequado e inclusivo às pessoas com deficiência. Reputou que a responsabilidade pela alteridade é um elemento estruturante da Constituição. Nesse sentido, a atuação do Estado na inclusão das pessoas com deficiência pressupõe a ideia de que essa ação tem via dupla, ou seja, traz benefícios a toda a população. Em outras palavras, todos os cidadãos têm o direito ao acesso a uma democracia plural, de pessoas, credos, ideologias e outros elementos. Especificamente, a Constituição prevê em diversos dispositivos a proteção da pessoa com deficiência (artigos $7^{\circ}$, XXXI; 23, II; 24, XIV; 37, VIII; 40, § 4 , I; 201, § $1^{\text {o; }}$; 203, IV e V; 208, III; 227, $\S 1^{\text {o }}$, II, e $\S 2^{\circ}$; e 244). Ao se compreender pluralidade e igualdade como duas faces da mesma moeda, entende-se que a igualdade não se esgota com a previsão normativa de acesso igualitário a bens jurídicos, mas engloba também a previsão normativa de medidas que possibilitem, de fato, esse acesso e sua efetivação concreta. A respeito, fora promulgado o Decreto 6.949/2009 (Convenção Internacional sobre os Direitos das Pessoas com Deficiência), que reconhece, em seu art. 24, o direito à educação como isento de discriminação e determina que os Estados partes da Convenção assegurem sistema educacional inclusivo em todos os níveis, de maneira que as pessoas com deficiência não poderão ser excluídas do sistema educacional geral sob alegação de deficiência.

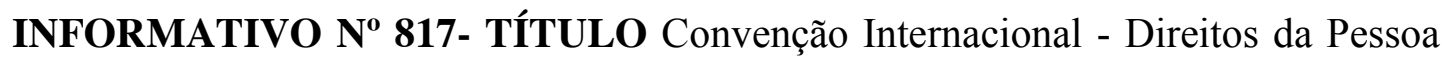
com Deficiência - Dignidade Humana - Ensino Inclusivo (Transcrições) PROCESSO -ADI 5357. ARTIGO. Convenção Internacional - Direitos da Pessoa com Deficiência - Dignidade Humana - Ensino Inclusivo (Transcrições) ADI 5.357 MC/DF* RELATOR: Ministro Edson Fachin EMENTA: AÇÃO DIRETA DE INCONSTITUCIONALIDADE. MEDIDA CAUTELAR. LEI 13.146/2015. ESTATUTO DA PESSOA COM DEFICIÊNCIA. ENSINO INCLUSIVO. CONVENÇÃO INTERNACIONAL SOBRE OS DIREITOS DA PESSOA COM DEFICIÊNCIA. INDEFERIMENTO. (...). Para além de vivificar importante compromisso da narrativa constitucional pátria - recorde-se uma vez mais a incorporação da Convenção sobre os Direitos das Pessoas com Deficiência pelo procedimento previsto no art. $5^{\circ}, \S 3^{\circ}, \mathrm{CRFB}$ - o ensino inclusivo milita em favor da dialógica implementação dos objetivos esquadrinhados pela Constituição da República. É somente com o convívio com a diferença e com o seu necessário acolhimento que pode haver a construção de uma sociedade livre, justa e solidária, em que o bem de todos seja promovido sem preconceitos de origem, raça, sexo, cor, idade e quaisquer outras formas de discriminação (Art. $3^{\circ}$, I e IV, CRFB). Esse foi inclusive um dos trechos da celebração da Convenção: "Reconhecendo as valiosas contribuições existentes e potenciais das pessoas com deficiência ao bem-estar comum e à diversidade de suas 
comunidades, e que a promoção do pleno exercício, pelas pessoas com deficiência, de seus direitos humanos e liberdades fundamentais e de sua plena participação na sociedade resultará no fortalecimento de seu senso de pertencimento à sociedade e no significativo avanço do desenvolvimento humano, social e econômico da sociedade, bem como na erradicação da pobreza, (...).

É importante considerar também que Ingo Sarlet (2006) considera a dignidade da pessoa humana como a qualidade intrínseca e distintiva reconhecida em cada ser humano que o faz merecedor do mesmo respeito e consideração por parte do Estado e da comunidade, implicando, nesse sentido, um complexo de direitos e deveres fundamentais que assegurem a pessoa tanto contra todo e qualquer ato de cunho degradante e desumano, como venham a lhe garantir as "condições existenciais mínimas" para uma vida saudável, além de propiciar e promover sua participação ativa e corresponsável nos destinos da própria existência e da vida em comunhão com os demais seres humanos.

Para Rizzatto Nunes (2002) assevera que a dignidade nasce com a pessoa, sendo-lhe inerente à sua essência. Contudo, nenhum indivíduo é isolado, haja vista que ele nasce, cresce e vive no meio social. E ai, nesse contexto, sua dignidade ganha um acréscimo de dignidade. Ele nasce com a integridade física e psíquica, mas chega um momento de seu desenvolvimento que seu pensamento tem de ser respeitado, suas ações e seu comportamento, isto é, sua liberdade, sua imagem, sua intimidade, sua consciência religiosa científica, espiritual, etc., tudo compõe o universo de sua dignidade.

Em face das diferentes opiniões retratadas anteriormente, defende-se que a dignidade da pessoa humana deva ser analisada tanto pelo aspecto subjetivo-moral, isto é, como atributo inerente de cada ser humano, quanto pelo objetivo, que, neste caso, refere-se à materialização dessa dignidade através do uso do próprio direito, pelo Estado, na garantia das condições essenciais de uma vida digna de sobrevivência. Logo, se uma pessoa com deficiência tem direito a alguma coisa, então é errado que o governo a prive desse direito, mesmo que seja do interesse de alguns procederem, assim, de forma contrária (DWORKIN, 2007).

\footnotetext{
${ }^{8}$ A vigente Constituição Federal elucida os direitos fundamentais sociais (Art. $6^{\circ}$ ) como exemplo de prestações materiais que visam garantir uma condição de vida digna, ou seja, direito à saúde, à educação, etc.
} 


\section{Estatuto da pessoa com deficiência e as novas regras da incapacidade civil}

Após o advento da Convenção sobre os Direitos das Pessoas com Deficiência9 incorporada ao direito interno brasileiro por meio do Decreto Legislativo 186, de 09/07/2008 e por sua promulgação pelo Decreto Executivo 6.949, de 25/08/2009 e, finalmente, a regulamentação da Convenção pela Lei 13.146 de 06/07/2015 (Estatuto da Pessoa com Deficiência), entretanto, houve uma mudança de paradigma quanto ao entendimento acerca do termo "deficiência". Considerando o art. 12 da referida Convenção ${ }^{10}$, aqueles indivíduos que apresentam impedimentos de longo prazo de natureza física, mental, intelectual ou sensorial, passaram a gozar de capacidade legal e plena em igualdade de condições com as demais pessoas em todos os aspectos da vida civil. Neste sentido, o Estatuto deixou de considerar as pessoas com deficiência como incapazes, enaltecendo o princípio da dignidade da pessoa humana, ou seja, abandona-se o paradigma da "dignidade-vulnerabilidade", valorizando-se a "dignidadeliberdade" ${ }^{11}$.

Além disso, o artigo $6^{\circ}$ da Lei $n^{\circ} 13.146 / 15$ dispõe que a "deficiência" não afeta a "plena capacidade civil” da pessoa com deficiência, isto é, a Lei assegura o direito ao exercício da capacidade em condições de igualdade com as demais pessoas, que foi alçado à hierarquia constitucional. Diante de tais mudanças trazidas pelo Estatuto, o vigente Código Civil sofreu alterações em alguns de seus dispositivos legais quanto às regras da incapacidade civil, conforme se observa:

\section{Antiga redação do Código Civil:}

Art. 3 São absolutamente incapazes de exercer pessoalmente os atos da vida civil:

I- os menores de dezesseis anos;

II- os que, por enfermidade ou deficiência mental, não tiverem o necessário discernimento para a prática desses atos;

III- os que, mesmo por causa transitória, não puderem exprimir sua vontade.

Nova redação do Código Civil após o advento do Estatuto das Pessoas com Deficiência:

Art. 3 São absolutamente incapazes de exercer pessoalmente os atos da vida civil os menores de dezesseis anos (grifo nosso):

I- (Revogado);

II- (Revogado);

\footnotetext{
${ }^{9}$ Convenção assinada em Nova York, em 30 de março de 2007, sendo que, em 2008, o Brasil ratificou a Convenção sobre os Direitos das Pessoas com Deficiência, adotada pela ONU, bem como seu Protocolo Facultativo.

${ }^{10}$ Artigo 12-

2. Os Estados Partes reconhecerão que as pessoas com deficiência gozam de capacidade legal em igualdade de condições com as demais pessoas em todos os aspectos da vida.

${ }^{11} \mathrm{O}$ conceito da dignidade-vulnerabilidade diz respeito o reconhecimento da necessidade de proteção aos vulneráveis, como garantia de sua dignidade, ao passo que a dignidade-liberdade assevera o reconhecimento de uma autonomia concreta, voltada à realização dos interesses existenciais e econômicos concretos da pessoa. (TARTUCE, 2016).
} 
III- (Revogado).

Antiga redação do Código Civil:

Art. 4 São incapazes, relativamente a certos atos, ou à maneira de os exercer:

I- os maiores de dezesseis e menores de dezoito anos;

II- os ébrios habituais, os viciados em tóxicos, e os que, por deficiência mental, tenham o discernimento reduzido (grifo nosso);

III- Os excepcionais, sem desenvolvimento mental completo (grifo nosso);

IV- os pródigos.

Parágrafo único. A capacidade do índio será regulada por legislação especial.

Nova redação do Código Civil após o advento do Estatuto das Pessoas com Deficiência:

Art. 4 São incapazes, relativamente a certos atos, ou à maneira de os exercer: I- os maiores de dezesseis e menores de dezoito anos;

II- os ébrios habituais, os viciados em tóxicos;

III- Aqueles que, por causa transitória ou permanente, não puderam exprimir sua vontade (grifo nosso);

IV- os pródigos.

Parágrafo único. A capacidade do índio será regulada por legislação especial.

Analisando os dispositivos retro, verifica-se que, após o advento do Estatuto das Pessoas com Deficiência, uma pessoa com deficiência mental ou intelectual passou a ser considerada plenamente capaz para os atos da vida civil, tendo em vista que a intenção do referido Estatuto foi ampliar os direitos fundamentais e valorizar a dignidade da pessoa com deficiência (DINIZ, 2016). É importante considerar também que não há mais no ordenamento jurídico civilista vigente incapacidade absoluta de maiores de dezesseis anos. Com isso, não se pode mais atribuir a condição de interdição absoluta, haja vista que "todas as pessoas com deficiência que eram tratadas no comando anterior passam a ser, em regra, plenamente capazes para o Direito Civil, o que visa a sua total inclusão social, em prol da sua dignidade" (TARTUCE, 2016, p. 129).

$\mathrm{Na}$ atual dicção das relativas incapacidades, adotam-se como justificativas:

1- Para os maiores de 16 e menores de 18 anos: Este critério é objetivo, tendo por fundamento mencionar a pouca experiência de vida da pessoa e seu insuficiente desenvolvimento mental. Logo, não houve alteração no atual Código Civil.

2- Para os ébrios habituais e viciados em tóxicos: Este critério já existe desde o advento do Código Civil vigente, tratando de reconhecer as dificuldades das pessoas que dependem do uso de tóxicos para discernir e praticar os atos da vida civil.

3- Para os que por causa permanente ou transitória não poderem exprimir sua vontade: Esta hipótese estava presente no art. $3^{\circ}$ do $\mathrm{CC} / 02$ e era tratada como modalidade de incapacidade absoluta. Todavia, trata-se de uma hipótese muito ampla, e que depende de laudo médico específico que deve definir o grau da dificuldade, da patologia apresentada pela pessoa 
com deficiência e em que medida ela pode discernir. É o caso, por exemplo, do portador do Mal de Alzheimer, Mal de Parkinson, dentre outros.

4- Para os pródigos: Também não representa alteração no CC/02. Estes sujeitos sofrem restrições por não terem o discernimento no uso de seus patrimônios sem comprometer suas subsistências e nem de suas famílias, ou seja, sem ser reduzidos à miserabilidade. Tal restrição refere-se à disposição patrimonial.

Dessa forma, o Estatuto retira do $\mathrm{CC} / 02$ os portadores de doença mental do rol dos absolutamente incapazes, sendo que tal alteração trouxe o reconhecimento da garantia de novos direitos. Estes últimos estão elucidados perante a regra do art. $6^{\circ}$ do Estatuto, dos quais se destacam alguns exemplos como:

Art. $6^{\circ}$. II - No que se refere aos direitos sexuais, ressalta-se é direito da pessoa com deficiência escolher livremente seus parceiros, respeitada inclusive sua orientação sexual (art.18, VI), desfazendo-se, de vez, o velho paradigma de que a pessoa com deficiência se trata de pessoa assexuada, que não conta com necessidades inerentes a qualquer ser humano (FARIAS, 2016).

Art. $6^{\circ} \mathrm{IV}, \mathrm{V}$ e VI-A despeito da deficiência, a pessoa pode manter intacta sua condição mental (e é mesmo assim na maioria das vezes), o que autoriza a prática de todos os atos da vida civil, dentre eles os acima elencados, em paridade de condições com outros eventuais candidatos.

Por outro lado, no que se refere à “curatela", alguns dispositivos legais do vigente Código Civil foram revogados, após o advento do Estatuto das pessoas com deficiência. Considerando a opinião doutrinária, Maria Berenice Dias (2016, p, 672) informa que: "não há como esgotar em rol taxativo as limitações ou inaptidões que geram o comprometimento da higidez da pessoa, sendo o grau de incapacidade ou comprometimento para os atos da vida civil avaliados em perícia médica". Considerando a opinião retro, é possível a curatela ser deferida em alguns casos, a depender do tipo específico da "deficiência", mesmo que a pessoa com deficiência ratifique a manifestação de sua vontade. Logo, o critério do discernimento deverá ser respeitado. Neste sentido, Silvio Venosa (2016, p. 515) busca respostas no novo Código de Processo Civil, a fim de ressaltar que a pessoa com deficiência mental ou intelectual pode ser curatelada. Segue opinião: 
(...) O Código de Processo Civil/2015 refere-se a doença mental grave, conforme art. 748 , caput (anterior art. 1.178, I). De qualquer forma, na expressão se incluem dos deficientes em geral, os psicopatas, portadores de anomalias que impedem o discernimento. Em razão de herança congênita ou adquirida, essas pessoas não têm condições de reger sua vida apesar de terem cronologicamente atingido a maioridade civil. Não é necessário darmos uma definição restrita aos amentais, pois o caso concreto e a perícia médica definirão a incapacidade.

Partindo do entendimento do autor elucidado anteriormente, é notório que em casos excepcionais de deficiência, como "mental ou intelectual", é possível haver solicitação de pedido de curatela mediante comprovação pericial médica. Mas, não se deve esquecer que, após o advento do Estatuto das pessoas com deficiência, a curatela deverá somente ser acionada em situações exclusivamente excepcionais, sempre quando houve limitações, conforme defende o art. 84, do referido Estatuto. Considera-se também que o novo conceito da curatela não visa alcançar o direito ao próprio corpo, à sexualidade, ao matrimônio, à privacidade, à educação, à saúde, ao trabalho e ao voto $\left(\S 1^{\circ}\right.$ do art. 85$)$, pelo contrário, ela afetará apenas os direitos de natureza patrimonial e negocial (caput do art. 85). Assim, a esfera personalíssima do curatelado deve ser preservada, o máximo possível, pois os assuntos personalíssimos que dizem respeito ao curatelado, conforme elencados anteriormente pela regra do $\S 1^{\circ}$ do art. 85 do Estatuto das pessoas com deficiência, não podem ser limitados pela vontade do curador.

Além disso, mesmo após o advento do Estatuto das pessoas com deficiência, porém a interdição prevalece como medida excepcional de proteção em prol daquela pessoa com deficiência que venha a necessitar, subsidiando da intervenção e reconhecimento da via judicia competente, com a finalidade de evitar dano ao patrimônio daquele interditando. Por conta disso, chega-se ao fim do procedimento tradicional da interdição que, até então, considerava como elemento principal de justificativa o aspecto personalíssimo do sujeito de direito. Não obstante, após o Estatuto, a interdição priva pelo resguardo e proteção do aspecto patrimonial, possibilitando uma verdadeira "flexibilização da curatela", ou seja, ajustada apenas às necessidades econômico-patrimoniais do interditando/curatelado.

Entretanto, eventuais termos de curatela, que já foram lavrados e expedidos em decisões judiciais anteriores ao advento do Estatuto das pessoas com deficiência, continuam válidos, embora a sua eficácia esteja limitada aos termos do Estatuto, ou seja, deverão ser interpretados em nova perspectiva para justificar a legitimidade e autorizar o curador atuar apenas para circunstâncias atreladas à prática de atos patrimoniais (TARTUCE, 2016).

Por outro lado, a "tomada de decisão apoiada" passou a ser analisado pelo Direito de Família, sendo que tal decisão se configura como um procedimento de jurisdição voluntária no qual a pessoa com deficiência elege pelo menos duas pessoas idôneas para lhe prestarem 
apoio na tomada de decisão sobre atos da vida civil, conforme explica a redação do art. 1.783A/CC. Os apoiadores irão fornecer informações necessárias ao exercício da capacidade civil em prol da pessoa com deficiência, sendo que:

Tecnicamente falando, a tomada de decisão apoiada não configura um 'processo', no
sentido técnico do termo, porque o processo é o instrumento de jurisdição, e, na
tomada de decisão apoiada, não existe exercício de jurisdição, tratando-se de mero
procedimento entre pessoas interessadas (não partes) e o Estado-juiz, encarregado de
fazer o papel de verdadeiro administrador judicial de interesse privado, verdadeira
'administração pública de interesses privados. (...) A petição deve ser subscrita por
advogado, regularmente inscrito na Ordem dos Advogados do Brasil, o que é
necessário, de resto, para qualquer procedimento de jurisdição voluntária. (ALVIM,
2015, p. 14)

Analisando a opinião retro, verifica-se que a tomada de decisão apoiada será analisada e discutida com o auxilio da via judicial competente. Tomando como exemplo os $\S \S 1^{\circ}$ e $2^{\circ}$ do artigo 1.783-A, o pedido de tomada de decisão é formulado pela pessoa com deficiência, devendo ser instruído com termo que contenha os limites do apoio a ser oferecido, os compromissos dos apoiadores, o prazo de vigência do acordo e o respeito à vontade, aos direitos e aos interesses da pessoa a ser apoiada. Além disso, o juiz competente, antes de se pronunciar, dará palavra ao representante do Ministério Público, ao requerente e às pessoas que lhe prestarão apoio, sendo assistido por equipe multidisciplinar. Por conta disso, a decisão tomada por pessoa apoiada terá efeitos sobre terceiros (regra do $\S 4^{\circ}$ do artigo 1.783-A). É importante considerar também que havendo divergência de opiniões entre a pessoa apoiada e o apoiador será resolvida pelo juiz, caso o negócio jurídico objeto da controvérsia possa trazer risco ou prejuízo relevante (regra do $\S 6^{\circ}$ ). A pessoa apoiada pode solicitar o fim do acordo (regra do $\S$ $9^{\circ}$ ), assim como o pode o apoiador (regra do § 10). Em caso de ação negligente, pressão indevida ou inadimplemento das obrigações, o apoiador será destituído pelo juiz (regra do $\S 7^{\circ}$ ).

Não se deve deixar de mencionar que a tomada de decisão apoiada não exclui a curatela e nem a substitui, podendo com ela conviver, como ocorre na França com sauvegarde de justice, pois, segundo a regra do $\S 11$, as mesmas disposições regerão ambos os institutos, no que tange à prestação contas, mas poderá provocar a ineficácia social da curatela por desuso. Logo, a tomada de decisão apoiada se apresenta, na verdade, como um concorrente da curatela em prol do auxilio as pessoas com deficiência (DINIZ, 2016).

Quanto ao aspecto da "responsabilidade civil", preleciona o art. 928 do CC e seu parágrafo único que os incapazes devem responder pelos prejuízos que causarem desde que as pessoas responsáveis não dispuserem de meios suficientes para fazê-lo, isto é, a indenização 
deve ser equitativa. Entretanto, o dever de indenizar não isenta o incapaz civilmente, apenas lhe dá um tratamento adequado à sua condição de incapacidade total ou relativa (STOCCO, 2016).

É possível, em alguns casos, possibilitar a exclusão da responsabilidade do incapazlesante se a indenização vier a privá-lo dos meios necessários à sua subsistência, porém deve se analisar cada caso particular, a fim de constatar ou não a necessidade de responsabilizar um incapaz civilmente, até porque, após o advento do Estatuto das pessoas com deficiência, houve alteração na regra das incapacidades, ampliando o rol da plena capacidade ao confirmar, por exemplo, os "excepcionais sem desenvolvimento mental completo" como "plenamente capazes" ao exercício dos atos da vida civil. Mas, a dúvida é: E se esses excepcionais sem desenvolvimento mental, mesmo sendo considerados, atualmente, como plenamente capazes pelo Estatuto, não puderem manifestar sua plena vontade e, de repente, viesse a cometer um ilícito civil, iriam ser responsabilizados civilmente pela conduta de seus atos? Portanto, conforme foi elucidado previamente, é imprescindível que seja analisado o caso concreto para saber se o art. 928 e parágrafo único/CC deve ou não ser aplicado diante dessas situações concretas.

\section{Conclusão}

Não se pode olvidar que a dinâmica do sistema jurídico nacional passou a reconhecer politicas públicas em prol da defesa dos direitos fundamentais das pessoas com deficiência. Dentre aquelas houve a publicação e o reconhecimento da Lei Brasileira de Inclusão da Pessoa com Deficiência (Estatuto da Pessoa com Deficiência) em 2015, sendo que proporcionou mudanças nas regras do estudo das incapacidades do direito civil.

Conforme se relatou no decorrer da pesquisa, a proposta do Estatuto das pessoas com deficiência foi no sentido de confirmar a participação plena e efetiva na sociedade daquela pessoa com alguma deficiência em igualdade de condições com as demais pessoas. Além disso, reflexos e implicações jurídicas o Estatuto passou a proporcionar para o instituto do Direito Civil, especificamente para a regra da Incapacidade Civil, no que tange a ampliação do reconhecimento do exercício da capacidade civil mediante, por exemplo, a reserva da curatela apenas e exclusivamente para situações excepcionais, sempre com limitações.

Assim, a curatela passou a ser considerada como medida protetiva extraordinária, além de proporcional às necessidades e às circunstâncias de cada caso e durará o menor tempo possível, devendo se pautar em decisão judicial bem arrazoada e motivada, conforme defende a regra dos artigos 84 e 85, do Estatuto da Pessoa com Deficiência. 
Outra implicação jurídica trazida pelo Estatuto foi o instituto da Tomada de Decisão Apoiada ou Assistida (regra do Art. 1.783-A, do vigente Código Civil) como instrumento adequado para o exercício pessoal da capacidade civil da pessoa com deficiência a ser exercido com segurança, sem que tal pessoa seja alijada do mundo jurídico e desconsiderando seus direitos. Neste sentido, caso a pessoa com deficiência venha a necessitar contratar, negociar ou fazer acordo com terceiros, ela poderá dispor e indicar duas pessoas de sua inteira confiança para orientação e acompanhamento na realização de atos da vida civil, fornecendo elementos e informações necessárias a fim de poder exercer sua capacidade. Indubitavelmente, os auxiliares ou acompanhantes na tomada de decisão apoiada deverão prestar compromisso perante o judiciário e também prestar contas, sob pena de serem destituídos e responder por danos nas esferas civil e penal.

Apesar de questionada por parte da doutrina, após o advento do Estatuto, o conceito de interdição foi reformulado em sua nova função e interpretação, haja vista que as pessoas com deficiência, cotidianamente, somente poderão ser interditadas quanto aos seus atos de caráter patrimonial e negocial, não mais atrelando às condições de limitação e deficiência. Com isso, os direitos das pessoas com deficiência, por exemplo, "casar", "trabalhar", "votar", entre outros, serão mantidos, pois somente através da lavratura de um laudo multiprofissional expedido por profissionais da psicologia, assistência social, pedagogia, entre outros, é que a interdição poderá será ratificada na via judicial competente. Importante não esquecer que o Estatuto passou a defender que a interdição poderá ser promovida não só pelo cônjuge e familiares, como pelo próprio interditando. Porém, a tomada de decisão apoiada deve ser discutida apenas por iniciativa do próprio interessado com deficiência, uma vez que estará em sua capacidade civil plena.

Por outro lado, a pesquisa também suscitou que o termo incapacidade não poderá mais estar associado à deficiência, pois o Estatuto reformulou as regras da incapacidade civil dos artigos $3^{\circ}$ e $4^{\circ}$, do Código Civil, reconhecendo, por exemplo, uma pessoa com deficiência "mental ou intelectual" que outrora era tida como absolutamente incapaz, remetendo-as para o rol dos relativamente incapazes.

Neste sentido, pode-se afirmar que os novos conceitos de deficiência e incapacidade civil estão em consonância com a ordem principiológica civil e constitucional, respeitando à dignidade da pessoa com deficiência para que possa gerir, na medida do possível, sua vida, a fim de escolher os seus interesses e aptidões, valendo-se, se for necessário, de ferramentas assistenciais para efetivação de atos negociais ou patrimoniais, a exemplo da curatela e tomada de decisão apoiada. 
Portanto, em que pese o necessário avanço legislativo, é prematuro confirmar a plena eficácia absoluta do Estatuto perante a sociedade como um todo, uma vez que se torna necessário dar continuidade a mudança nas retrógradas mentalidades de algumas pessoas conservadoras que insistem em ignorar o reconhecimento dos direitos fundamentais das pessoas com deficiência. É um desafio que somente o fator tempo confirmará a absoluta inclusão social.

\section{Referências bibliográficas}

ALVIM, J. E. Carreira. Tomada de decisão apoiada. Revista Brasileira de Direito Processual - RBDPro, Belo Horizonte, ano 23, n. 92, out./dez. 2015. Disponível em: $<$ http://www.bidforum.com.br/bid/PDI0006.aspx?pdiCntd=239218>. Acesso em 22 abr. 2018.

ARAÚJO, Luiz David. Reflexões sobre a Convenção sobre direitos das pessoas com deficiência e sua efetividade no sistema constitucional brasileiro. In: Liber Amicorum. Homenagem do Prof. Doutor Antônio José Avelãs Nunes. São Paulo: Ed. Coimbra, 2009.

BRASIL. Supremo Tribunal Federal. Ação direta de inconstitucionalidade $n^{\circ} 5.357 \mathrm{MC}$ Referendo/DF- Distrito Federal. Relator: Ministro Edson Fachin. Pesquisa de Jurisprudência, Informativo $\mathrm{n}^{\circ} .829,09$ junho 2016. Disponível em: <http://www.stf.jus.br/arquivo/ informativo/documento/informativo829.htm>. Acesso em: 09 abr. 2018.

BRASIL. Supremo Tribunal Federal. Ação direta de inconstitucionalidade $n^{0} 5.357$ MCReferendo/DF- Distrito Federal. Relator: Ministro Edson Fachin. Pesquisa de Jurisprudência, Informativo $\mathrm{n}^{\circ} .817,18$ novembro 2015. Disponível em: <http://www.stf.jus.br/ arquivo/informativo/documento/informativo817.htm\#transcricaol>. Acesso em: 09 abr. 2018.

CANOTILHO, J.J. Gomes. Direito Constitucional e Teoria da Constituição. 5. ed. Coimbra: Almedina, 2002

CUNHA JUNIOR, Dirley da. Curso de direito constitucional. 9. ed. Salvador: Jus Podivm, 2015. 
CUPIS, Adriano de. Os Direitos da Personalidade. Tradutor Afonso Celso Furtado Rezende. Campinas: Ed. Romana, 2004.

DIAS, Maria Berenice. Manual de direito das famílias. São Paulo: Revista dos Tribunais, 2016.

DINIZ, Maria Helena. A nova teoria das incapacidades. Revista Thesis Juris - RTJ. São Paulo. n. 2, v. 5, Mai- Ago 2016 . Curso de Direito Civil. v. 1. São Paulo: Saraiva, 2016.

DWORKIN, Ronald. Levando os direitos a sério. 2. ed. São Paulo: Martins Fontes, 2007.

FARIAS, Cristiano de Chaves. Estatuto da Pessoa com Deficiência Comentado. 1. ed. Salvador: Jus Podivm, 2016.

GONÇALVES, Carlos Roberto. Direito Civil Brasileiro. 14. ed. vol. 1. São Paulo: Saraiva, 2016.

MELLO, Celso Antônio Bandeira de. Conteúdo Jurídico do Princípio da Igualdade. 3. ed. São Paulo: Malheiros Editores, 1998.

MORAES, Guilherme Peña de. Curso de Direito Constitucional. 7. ed. São Paulo: Atlas, 2015.

NUNES, Rizzatto. O princípio constitucional da dignidade da pessoa humana. São Paulo: Saraiva, 2002.

REQUIÃO, Maurício. Estatuto da Pessoa com Deficiência, incapacidades e interdição. Salvador: Jus Podivm, 2016.

SANTOS, José Maria Carvalho dos. Código Civil Brasileiro Interpretado. Rio de Janeiro: Freitas Bastos S. A, 1987. 
SARLET, Ingo Wolfgang. Dignidade da Pessoa Humana e Direitos Fundamentais na Constituição de 1988. Porto Alegre: Livraria do Advogado, 2006.

SILVA, José Afonso da. Comentário contextual à Constituição. 7. ed. São Paulo: Malheiros, 2010.

STOCCO, Rui; OMELETTO, Rosália T. V. Código Civil Interpretado. 9. ed. São Paulo: Manole, 2016.

TARTUCE, Flávio. Alterações do Código Civil pela lei 13.146/2015 (Estatuto da Pessoa com Deficiência). Repercussões para o Direito de Família e Confrontações com o Novo CPC. Parte II. Disponível em: <http://www.migalhas.com.br/FamiliaeSucessoes/ 104,MI225871,51045Alteracoes + do + Codigo + Civil + pela + lei $+131462015+$ Estatuto + da $+P e$ ssoa + com >. Acesso em: 16 abr. 2018.

Direito civil: Lei de Introdução e Parte Geral. Vol. 1 (12a. ed.). São Paulo, BR: Grupo Gen - Editora Forense, 2016.

TEPEDINO, Gustavo. O Código Civil na Perspectiva Civil-Constitucional. Rio de Janeiro: Renovar, 2013.

VENOSA, Silvio de Salvo. Direito Civil: Parte Geral. 16. ed., v. 1. São Paulo: Atlas, 2016. . Direito civil: direito de família. 16. ed. São Paulo: Atlas, 2016. 


\title{
O CONCEITO DE DIREITO DE AUTODETERMINAÇÃO \\ INFORMACIONAL E A ANÁLISE DO DANO: REFLEXÕES PARA QUE A \\ RESPONSABILIDADE CIVIL ENCONTRE SUA MEDIDA E EXTENSÃO NA SOCIEDADE CONTEMPORÂNEA
}

\author{
Karin Anneliese Pupp \\ Universidade Federal de Santa Catarina
}

\begin{abstract}
Resumo
O artigo objetiva disseminar o conceito de autodeterminação informacional para contribuir na assimilação da ocorrência de um dano ressarcível. Embora o legislador tenha introduzido mecanismos que viabilizam o exercício da Selbstbestimmung, sua noção não se encontra difundida, o que se mostra importante, pois esse direito introduz uma nova forma de proteção, repercutindo na configuração do dano ressarcível. Analisa teorias do dano e a corrente que sustenta sua prescindibilidade e conclui que merecem esforços os estudos acerca da sua caracterização, pois a clarificação sobre sua ocorrência na sociedade contemporânea pode permitir que as interações sociais se desenvolvam de forma mais segura.
\end{abstract}

Palavras-chave: autodeterminação informacional, dano ressarcível.

\begin{abstract}
Resumen/Résumé
The article intends to disseminate the concept of informational self-determination, in order to contribute to the assimilation of reimbursable damage occurrences. Although the legislator has introduced mechanisms that make it possible to exercise the Selbstbestimmung, its notion is not widespread, which is important insofar as this right introduces a new form of protection, affecting the configuration of the damage that can be reimbursed. It analyzes theories of damage and the current that supports its dispensability concluding that those theories deserve further study, since the clarification of its occurrence in the contemporary society may allow social interactions to develop more safely.
\end{abstract}

Keywords/Palabras-claves/Mots-clés: Informational self-determination right - indemnifying damages. 


\section{Introdução}

O conceito do direito de autodeterminação informacional, desenvolvido na Alemanha sob a designação da Selbstbestimmung, encontra na Lei do Cadastro Positivo (Lei 12.414/2011) a incorporação de mecanismos desenvolvidos pelo operador alemão para o seu exercício. Desse modo, o ordenamento jurídico brasileiro conta com a introdução de um novo direito, a requisitar a sua disseminação na doutrina e jurisprudência nacional, em especial, para clarificar em quais situações pode-se ter por configurado um dano ressarcível.

A temática encontra sua importância, quando se percebe que as discussões mais recentes dentro da responsabilidade civil ampliam o seu alcance, sob o argumento de conter o sentimento de insegurança vivenciado pelo homem contemporâneo, que se percebe inseguro quanto aos possíveis resultados que os avanços tecnológicos e científicos podem ocasionar. $\mathrm{E}$ sob esse pretexto crescem movimentos defensores da existência de uma responsabilidade civil sem dano. Trata-se de um entendimento que mexe com a estrutura do instituto, o que pode causar impactos em todo sistema jurídico, razão pela qual merece a reflexão sobre suas repercussões.

Nas relações de concessão de crédito, o legislador nacional optou por ampliar a fonte de coleta de informações, a fim de introduzir no mercado uma forma de gestão mais responsável, regulamentando os chamados cadastros positivos. Criou-se a possibilidade de historiar o perfil de adimplemento do consumidor, aumentando o influxo de informações que podem ser utilizadas. Essa nova normatização permitiu que esse influxo seja gerenciado através da atitude ativa do consumidor, ao qual é conferido o poder de autodeterminar a extensão e medida do uso de seus dados. Tal tratamento, introduz uma nova percepção da proteção de direitos, com reflexos na análise de configuração do dano.

Nesse sentido, o presente artigo tem como escopo disseminar o conceito do direito de autodeterminação informacional (a Selbstbestimmung), no fito de contribuir para clarificar e auxiliar na identificação das situações ensejadoras de danos jurídicos. O que, por fim, pode facilitar que as relações sociais se desenvolvam com maior segurança e confiabilidade, requisitando a responsabilidade civil de forma compactuada com as necessidades do homem contemporâneo.

A fim de atingir o objetivo proposto, utilizou-se o método indutivo e a técnica da pesquisa bibliográfica em leis, artigos e obras referentes ao tema. 


\section{O direito de autodeterminação informacional: conceito e origem}

O Tribunal Constitucional Federal na decisão denominada Volkszahlungsurteil, desenvolveu o Grundrecht auf informationelle Selbsbestimmung, traduzido como o direito de autodeterminação informacional. Antes desse precedente a Corte Alemã trabalhava com a teoria das esferas do direito à personalidade (Persönlichkeitskerntheorie), pela qual se conferia uma proteção diferenciada, caso a esfera atingida fosse da intimidade, privacidade ou social. Apenas a primeira esfera era considerada intocável, admitindo a segunda o princípio da proporcionalidade e na última as intromissões seriam toleradas (MARTINS, 2005, p. 187).

Ocorre que cientificamente se mostra difícil definir as fronteiras entre essas esferas e, por conta disso, essa teoria recebeu severas críticas (MARTINS, 2005, p. 189). Presente na decisão do Mikrozensusurteil (1965), a teoria foi superada pela Volkszahlungurteil em 1983. No primeiro caso, o governo federal alemão planejava conduzir um recenseamento geral da população, mas por conta do apelo público foram opostas reclamações constitucionais no Bundesverfassungsgericht, suspendendo temporariamente o censo. Nessa Mikrozen, a Corte entendeu que o Estado não poderia de forma obrigatória registrar e catalogar os dados pessoais, considerando ser sua esfera intima intocável. Esse entendimento pautado na proteção da privacidade, limita o uso do influxo de informações pessoais. Dessa forma, a análise sobre a ocorrência de um dano passa pela discussão acerca da transgressão desse limite, o que por vezes pode encontrar uma zona gris, posto que eminentemente subjetiva.

Em que pese a decisão, o parlamento alemão aprovou a lei para o censo da população (Volkszählungsgesetz), ordenando o "recenseamento geral da população, com dados sobre a profissão, moradia e local de trabalho para fins estatísticos" (MARTINS, 2005, p. 233). O objetivo da lei era fazer um levantamento sobre o estágio do crescimento populacional, para substanciar decisões político-econômicas. A lei do censo de 1983 listava os dados que deviam ser levantados pelos pesquisadores e determinava quem estava obrigado a fornecer as informações, permitindo, ainda, uma comparação dos dados levantados com os registrados públicos. Frente a isso, não foram poucas as reclamações ajuizadas perante a Corte Federal Alemã, alegando a violação ao direito ao livre desenvolvimento da personalidade, previsto no artigo 2 I GG (MARTINS, 2005, p. 229).

Novamente incitado a se pronunciar, o Bundesverfassungsgericht então altera a abordagem da matéria, sob o argumento que a proteção do indivíduo contra levantamento, armazenamento, uso e transmissão irrestrito de dados se encontra amparado na lei fundamental, nos artigos 1 I GG e 2 I GG (DEUTSCHER BUNDESTAG, 2017), não por limitar o uso de 
seus dados pessoais, mas por garantir ao indivíduo o poder de decidir ele mesmo sobre sua exibição.

A postura passiva presente na teoria das esferas foi substituída por uma conduta ativa do cidadão, que através do seu poder de autodeterminação decide, em princípio, o uso e extensão de seus dados pessoais. Asseverou o Tribunal Alemão que as intervenções estatais podem, contudo, ser oponíveis em face do direito de autodeterminação informacional, mas somente em caso de interesse predominante da coletividade, encontrando-se, ainda, restrito à finalidade previamente estabelecida em lei. Ademais, considerou que outras medidas processuais essenciais de proteção são necessárias, estabelecendo os deveres de esclarecimento, informação e apagamento dos dados (MARTINS, 2005, p. 238).

Supera-se a teoria das esferas (Spharenteorie), enquanto critério de aferição de lesão à privacidade dos cidadãos, e confere-se ao indivíduo um viés ativo para, a partir do livre desenvolvimento da personalidade, exercer sua autonomia informacional.

Em síntese, pode-se dizer que o direito de autodeterminação informacional é a capacidade de o indivíduo determinar sobre a exibição e uso de seus dados pessoais. Conforme Wolfgang Hoffmann-Riem, não se trata de um direito de defesa privativo do indivíduo, que a opõe a sociedade, mas visa uma postura ativa, possibilitando a cada um a participação no processo de comunicação de dados pessoais (2010, p. 56).

E, nesse sentido, é possível verificar que de um lado o direito à autodeterminação informacional possui caráter subjetivo, quando analisado sob o enfoque do poder do indivíduo de determinar a medida e extensão do uso de suas informações pessoais. De outro, possui caráter objetivo, vez que o seu exercício requer a presença de mecanismos de conhecimento, transparência e publicidade, o que demanda a atuação do legislador.

Com isso, percebe-se que o direito de autodeterminação informativa é exercido por meio de mecanismos de conhecimento, transparência e publicidade, o que no contexto dos arquivos de consumo se garante: a) pelo acesso e esclarecimento dos registros, de forma compreensível e gratuita; b) pela informação da finalidade e transmissibilidade das informações; c) pela possibilidade de oposição e correção dos dados armazenados de forma inexata, desatualizados, e a eliminação dos dados que não respeitem as regras ou princípios protetivos, bem como, o cancelamento de dado decorrido em determinado período ( direito de esquecimento)" (EIRAS, 1992, p. 259).

Confere-se, assim, aos indivíduos o direito de decidir e administrar o uso de seus dados pessoais, estabelecendo os limites e a extensão da exposição de suas informações, de modo que a análise do dano deixa de se encontrar na discussão abstrata acerca da transgressão dos limites 
das esferas da intimidade e privacidade, para assumir uma forma de configuração mais concreta e objetiva, conforme se examina adiante.

\section{Evolução e teorias da configuração do dano e sua ocorrência frente ao direito de autodeterminação informacional}

A noção de dano acompanha a evolução social, portanto, apresenta uma dinamicidade e crescente transformação. Em um primeiro momento marcado por uma sociedade eminentemente agrária, o dano não era associado a um prejuízo e nem se separava o dano a pessoa do dano a coisas. O direito romano, não contou com um conceito de dano, sendo considerado na Lex Aquilia como "ataque à integridade da uma coisa sem indagação acerca da existência de prejuízo efetivo ao proprietário". É no direito moderno, com a formação de cidades industriais, aumento populacional e intensificação das interações relacionais que se solidificam maiores indagações acerca de sua caracterização, terminologia e alcance (SANSEVERINO, p. 137).

No Estado Liberal, o conceito de dano ganha uma forte influência individualista e patrimonialista, focado na proteção da propriedade. Ocorre que com a revolução industrial aumentam-se as possibilidades de acidentes, colocando a figura da vítima no foco das discussões, especialmente pela formação do Estado Social e a introdução do princípio da proteção integral da pessoa humana. O viés individualista é substituído pelo social, o qual é, por sua vez, alterado com a revolução tecnológica pelo paradigma do risco. Isso porque, frente aos avanços da tecnologia, da informática e da ciência, o homem contemporâneo passa a se perceber inseguro quanto aos resultados decorrentes desse progresso. Aumenta-se cada vez mais as exigências de proteção, ampliando a noção do conceito de dano, a fim de abranger um maior número de situações. Neste movimento de crescente progresso e ampliação, a noção de dano resta bastante difundida tornando, por vezes, nebulosa sua caracterização. Todo e qualquer menoscabo decorrente da relação social começa a ser invocado como hipótese de ressarcimento.

O conviver em sociedade pode, por vezes, ocasionar um dano. Todavia, nem todo e qualquer dano é suficiente para requisitar uma tutela ressarcitória. Em virtude disso, a doutrina busca construir o conceito de dano em sentido jurídico, dissociando-o do dano em um sentido vulgar ou natural.

Assim, frente a todas as novas possibilidades de danos, faz-se necessário ter presente a noção clara e precisa acerca da caracterização de um dano ressarcível, o qual, tem sido, inclusive, dispensado por uma linha de pensamento. A ausência do requisito da configuração 
de um dano ressarcível e da identificação do âmbito da tutela ressarcitória, podem tornar a vida cotidiana uma incessante fonte de danos. Essa preocupação se encontra presente na obra de Calvo Costa (2005, p. 61), a qual é aqui utilizada para fins de sistematização das teorias acerca do dano, que são, assim, divididas: dano como detrimento de um bem jurídico; dano como violação de um direito subjetivo; dano como lesão a um interesse jurídico; e o dano definido por suas transcendências, repercussões ou resultados.

\subsection{Dano como detrimento de um bem jurídico}

O dano para esta teoria é o menoscabo a um bem jurídico, no qual se incluem as coisas e os bens ou direitos que não são coisas (COSTA, 2005, p. 63). Nesse sentido, dano em sentido vulgar e dano em sentido jurídico se diferenciam porque este último recebe uma qualificação, qual seja a afetação do prejuízo (seja ao corpo, alma ou coisa) a um bem jurídico. Nas palavras de Hans Fischer (1938, p. 07), a noção vulgar de dano é "todo prejuízo que alguém sofre em sua alma, corpo ou bens", ao passo que a definição jurídica abrange "todo o prejuízo que o sujeito de direito sofra pela violação dos seus bens jurídicos, com exceção única daquele que a si mesmo tenha inferido o próprio lesado".

Dentre os autores brasileiros Aguiar Dias considera acertada a definição de Hans Fischer, que parte das duas concepções do dano (vulgar e jurídica), e afirma que a noção de dano se restringe a ideia de prejuízo, que é resultado da lesão sem discussão sobre o valor dos elementos (2006, p. 971, 972).

Todavia, são apresentadas críticas a esta teoria, e uma delas pontua para a equivocada percepção de que do prejuízo sobre um bem de ordem econômica, geraria um dano de ordem patrimonial, ao passo que um dano a um bem sem esse cunho, acarretaria um dano extrapatrimonial. Tal acepção gera problemas para se diferenciar danos patrimoniais de danos extrapatrimoniais, pois da violação a um bem patrimonial podem decorrer prejuízos extrapatrimoniais, como no exemplo do inadimplemento de um contrato de transporte ao gerar a frustração das férias. O contrário também pode ser notado, ou seja, existir uma repercussão econômica decorrente de um evento lesivo de ordem extrapatrimonial (COSTA, 2005, p. $63,64)$.

Outro argumento a refutar a presente teoria, encontra-se nas lições de Pontes de Miranda, ao destacar que nem todo fato ilícito que destrói ou deteriora algo de alguém gera um dano que se tenha de ressarcir, a exemplificar: a "pedra jogada que rola pela ribanceira sem ofender qualquer planta, ou só ofendeu planta que ia ser ou devia ser cortada, porque não mais 
daria frutos", a destruição de um prédio em ruínas que seria de igual forma demolido pelo seu proprietário. Lado outro, se mantém a ressarcibilidade de um bem "roubado, ou furtado" se ninguém o usucapiu, porque o bem ainda é reivindicável, ou de posse vindicável, ou restituível, ou seja, continua contendo um valor patrimonial (MIRANDA, 2012, p. 264).

Os exemplos permitem concluir que a teoria se mostra ampliativa, pois considera ocorrido um dano mesmo quando a lesão sobre o bem não cause um desvalor ao seu titular, podendo assim abranger situações nas quais se tem apenas uma conduta ilícita. Todavia, imperou durante muito tempo na Itália, cuja superação é encontrada na obra de Carnelutti, que passou a sustentar que o dano é muito mais que uma lesão a um bem (COSTA, 2005, p. 65).

\section{2 Dano como violação de um direito subjetivo}

Uma tese mais restritiva da configuração do dano é a que o define a partir da lesão a um direito subjetivo. Portanto, não basta a lesão a um bem jurídico, somente se configurando um dano se houver uma transgressão da garantia outorgada pela norma a uma pessoa titular de um bem (COSTA, 2005, p. 66).

Na definição de Francisco Amaral (2003, p. 187), o direito subjetivo é um poder conferido pela ordem jurídica para que alguém possa agir ou exigir um determinado comportamento de outrem, sob pena de sanção. A norma configura-se como legitimadora do interesse do indivíduo, conferindo a ele um poder de atuar de forma exclusiva, e o dano restará configurado frente a lesão desse direito.

Essa corrente mantém o problema da anterior quanto à análise da configuração de um dano moral ou patrimonial, pois reputa a ocorrência de um ou outro a depender da índole do direito subjetivo afetado. A crítica é igual, indicando que de uma lesão de índole patrimonial pode resultar um prejuízo de ordem moral, e vice-versa (COSTA, 2005, p. 67).

A apresentação deste critério mais restrito não encontrou uma ampla aceitação, especialmente por descartar a existência de simples interesses que podem ter uma repercussão jurídica relevante. Tais interesses não receberiam guarida por não estarem tutelados pela norma. Ocorre que, um interesse simples pode se revestir de um caráter sério e lícito, como fatores de ressarcimento, devendo ser igualmente protegidos por razões de equidade e solidariedade social. (COSTA, 2005, p. 68). Existem, assim, situações nas quais o titular de um interesse lesado não chega a ser detentor de um direito subjetivo, como se dá no exemplo citado por Calvo Costa (2005, p.68) da concubina que tem legitimidade para reclamar uma indenização pelo advento da morte do concubino decorrente de uma conduta ilícita, ou no exemplo de 
Zannoni (1987, p. 29,30) da criança órfão sustentada por uma pessoa sem vínculo de parentesco, que falece e decorrência de um ato ilícito. Em ambos os casos, embora os sujeitos não sejam juridicamente dependentes, podem ter uma dependência econômica, e nessa medida a morte, do concubino e do benfeitor, ocasionam lesão a interesses legítimos.

Dentre os autores brasileiros, Sanseverino (2010, p. 144) considera essa orientação mais restritiva e ligada aos direitos subjetivos. Apresenta-se como um modelo clássico individualista e privatístico, que "concebe proteção efetiva apenas às lesões a interesses individuais, que consubstanciam lesão a direitos subjetivos de uma pessoa determinada". E nesse sentido, se mostra "insuficiente para atender às novas demandas da sociedade contemporânea nos casos de ofensas a interesses fragmentários de toda uma coletividade, como ocorre com as agressões a interesses difusos". Desta forma, em sua linha de pensamento, para além de uma noção privatística e individualista é necessário abrir portas para a concessão de tutela jurídica efetiva aos interesses difusos e coletivos, cada vez mais presentes na sociedade contemporânea marcada pela massificação das relações sociais.

\section{3 Dano como lesão a um interesse jurídico}

Essa teoria utiliza como núcleo da tutela jurídica o interesse humano. Dentro disso, enquadram-se tanto os bens como os direitos subjetivos que confiram ao seu titular uma satisfação, a cuja lesão ou violação originará um dano jurídico, e em face dele o direito apresenta uma reação. O interesse que não estiver tutelado pelo direito, nem explícita nem genericamente, "que consista unicamente em um simple menoscabo a bienes", não provocará a reação do sistema a fim de lhe conceder uma reparação (COSTA, 2005, p. 70, 71,72).

O objeto do dano identifica-se com o objeto da tutela jurídica, que é, para esta corrente, sempre um interesse humano. A simples lesão a um bem, sem atingir um interesse protegido, preenche um sentido meramente naturalístico na noção de dano, pois somente a lesão que recaia sobre um bem que satisfaça um interesse humano, gera um dano em sentido jurídico (COSTA, ANO, p.72). Desta forma, para essa corrente o direito não está a proteger um bem abstratamente considerado, pois é necessário analisar se o bem satisfaz uma necessidade humana legítima.

Assim, para caracterização do dano torna-se importante perceber que bem e interesse são coisas distintas. Na lição didática de Fernando Noronha (2013, p.579,580), bens "são as coisas do mundo externo (corpóreas ou incorpóreas) e as qualidades internas das pessoas; já o interesse é a relação que liga uma pessoa aos bens com objetivos econômicos ou ideais. 
Assim, no modelo do interesse é necessário que o bem represente um valor para o seu titular. De modo que, um bem que não pertença a ninguém (res nullius), que não satisfaça o interesse de alguém, não provocará a reação do sistema jurídico, posto que não há interesse jurídico lesionado e, portanto, um dano jurídico (CALVO, 2005, p. 73).

Em suma, somente haverá dano que provoque a reação jurídica quando a afetação ao bem vulnerar o interesse de seu titular (CALVO, p. 73), que poderá ocorrer de duas maneiras: por meio da alteração ou cerceamento da possibilidade do bem satisfazer uma necessidade de seu titular; ou alteração da própria essência do bem, de modo a torna-lo inapto para a satisfação das necessidades de seu dono.

Quanto aos simples interesses, embora não possuam uma proteção normativa específica, adquirem uma tutela jurídica de forma genérica quando importam meios para satisfazer necessidades humanas. Como menciona Calvo Costa, o interesse simples constitui uma faculdade de atuar não repudiada pelo direito e que será tutelado por ele na medida em que se mostrem sérios e legítimos. É a sua minoração que se mostra antijurídica e apta para gerar consequências danosas (COSTA, 2005, p.77). Nesse sentido, defende Zannoni (2005, p. 29,30) que a noção moderna de interesse não deve ser restringida à de interesse juridicamente tutelado, mas à de interesse não proibido pela ordem jurídica.

Essa teoria, que tem em Carnelutti (1930, p.14) seu grande mentor, sustenta que o dano está relacionado com a violação ao interesse humano legítimo, com a perda, alteração ou diminuição do bem que obsta a satisfação da necessidade de seu titular. E o dano será moral ou material a depender do interesse jurídico violado.

$\mathrm{Na}$ doutrina brasileira, encontra nas lições de Pontes de Miranda (1981, p. 206), a identificação que a base do dever de indenizar é o interesse do ofendido, que pode ser patrimonial ou pessoal. Portanto, o dano sobre um patrimônio que não seja de alguém não é um dano ressarcível e o mesmo ocorre se da conduta não resultar uma afetação ao patrimônio material ou pessoal tornando-o inapto para a satisfação da necessidade de seu titular.

E, no entendimento de Sanseverino (2010, p.145), esse modelo do interesse é o mais acertado, posto "que explica de modo mais completo a noção moderna de dano, abrindo portas para o reconhecimento de novas modalidades de prejuízo".

\section{4 Dano definido por suas transcendências, repercussões ou resultados}

Por fim, os adeptos da última corrente sistematizada por Calvo Costa sustentam que o dano jurídico se identifica com as consequências prejudiciais decorrentes da lesão a um bem 
patrimonial ou extrapatrimonial ou a um interesse. Assim, lesão e dano se encontram em uma relação de causa e efeito, onde a lesão é a causa e o dano seu possível efeito (2005, p.79).

Sustentam, assim, que a bifurcação da noção do dano em sentido lato e stricto ocorre nesta relação causa e efeito. O entendimento amplo do dano alcança qualquer ofensa ou lesão a direito ou interesse legítimo, patrimonial ou extrapatrimonial e, apenas, se desta causa decorrer uma consequência prejudicial é que se terá um dano em sentido stricto.

Nesta definição, o ato ilícito que consiste na ação ou omissão que invade a esfera de direitos alheios, é percebido como fonte geradora de um dano em sentido lato, para o qual se concede uma tutela de remoção ou prevenção da ilicitude. Como exemplo, o proprietário que avança suas construções no espaço aéreo do vizinho, poderá ser demandado a demolir sua obra na parte que invade domínio alheio, mesmo que não se prove a configuração de um prejuízo. Trata-se de hipótese de ato ilícito e não de dano ressarcível (ORGAZ, 1967, p.3).

Com isso, a conclusão que chegam seus teóricos é de que a lesão (causa) é um dano em sentido amplo e o menoscabo, o prejuízo ou o resultado da lesão, é um dano em sentido stricto, e este sim, um dano ressarcível, "el único que trasciende juridicamente y que debe interesar a los fines de su reparación" (CALVO, 2005, p. 80).

O dano ressarcível transcende o significado da mera lesão para significar a consequência prejudicial advinda da conduta lesiva. O dano ressarcível, portanto, não seria a lesão em si mesma, mas sim seus efeitos. E dessa forma, o dano patrimonial ou extrapatrimonial não estaria subordinado a natureza do direito lesionado, mas na classe do prejuízo provocado pela lesão. Assim, o dano será patrimonial ou extrapatrimonial, a depender da repercussão maléfica ter atingido a coisa ou a pessoa.

Para essa corrente doutrinária, considera-se o dano jurídico e ressarcível aquele que decorre das consequências prejudiciais da lesão, não o deduzindo da antijuridicidade. $O$ contrário, alertam seus partidários, pode permitir que se chegue ao extremo de considerar ressarcível a ação contrária ao direito sem necessidade de provar a existência de um prejuízo capaz de estabelecer um dano. Todavia, não negam que em um sentido amplo pode haver um dano a um interesse (ex: publicidade enganosa ou abusiva, sem afetar qualquer consumidor, violação ao domicílio sem causar deterioração ao bem), ligando-se apenas à antijuridicidade, e não à responsabilidade civil ressarcitória. Tratam-se, em resumo, de ilícitos civis sem dano (ZAVALA DE GONZÁLEZ, 2009, p. 11). Portanto, da presente teoria é importante destacar que a ilicitude não produz de per si responsabilidade civil, a violação de um direito, somente enseja ao ressarcimento, ao dano indenizável, quando houver um prejuízo. 
No Brasil, Fernando Noronha (2010, p. 579) esboça argumentos que acompanham a teoria do dano considerado pelo resultado da conduta lesiva. É o que se percebe da sua definição, que "o dano pode ser caracterizado simplesmente como sendo o prejuízo resultante de uma lesão antijurídica de bem alheio" e ressalta, adiante, que o dano não é apenas violar, dano é a consequências prejudicial resultante da violação. Em seus ensinamentos, ao mesmo tempo que o "dano é prejuízo gerado num bem, isto é, numa coisa, ou no corpo ou alma de uma pessoa", menciona que na relação dano e bem violado, aquele não é propriamente a violação deste, mas as consequências nefastas resultantes da violação. A violação em si configura apenas o fato antijurídico, que é o primeiro pressuposto da obrigação de indenizar.

Assim, na doutrina nacional também se defende que na relação dano e bem, dano não é apenas a violação, dano é a consequências prejudicial resultante da violação. Do que se sustenta que violar um bem é apenas fato antijurídico, pressuposto para indenizar, ausente apenas em casos especiais, como no caso da responsabilidade dos pais pelos filhos menores ou donos de animais. De toda forma, o que se tem é que "a circunstância de o dano ser proveniente de um ato ou fato antijurídico é que lhe dá a condição de lesão antijurídica ou injusta”, mas a ressarcibilidade advém nesta linha de pensamento de um consequente lesivo (NORONHA, p. $580)$.

Judith Martins-Costa (2003, p.108) também percebe que o dano não consiste na lesão em si mesma, mas sim nos seus efeitos, ao defender que "do dano injusto decorre a noção de 'dano ressarcível', que se identifica com as consequências prejudiciais que descendem da injusta lesão, determinando in concreto o conteúdo da obrigação de ressarcir a cargo do responsável”.

Essas duas últimas teorias apresentam um conceito de dano jurídico, dividindo situações em que existiria um dano em sentido amplo e outras que configuram um dano ressarcível, seja pela violação a um interesse jurídico ou produção de um consequente. Calvo Costa, em conclusão, afirma que ambas teorias se complementam e levam parte de razão. O intérprete usaria como plataforma de partida para a análise da configuração do dano a teoria do interesse, pois quando se seleciona os danos ressarcíveis o foco está no interesse do sujeito e no segundo momento, quanto da fixação do ressarcimento se deve apreciar as consequências para definir o quantum indenizatório (2005, p. 94).

Dentre nossos estudiosos, Cavalieri (2015, p. 103) considera que quando doutrina e a jurisprudência definem o dano pelos seus efeitos ou consequências, acabam por utilizar como ponto de partida uma "noção aberta" e "um conceito amplíssimo". O fazem isso, quando caracterizam o dano pelo prejuízo, "ou, no caso do dano moral”, quando houver "dor, vexame, 
sofrimento e humilhação", conceituando o dano pelas suas consequências. Tal critério, na opinião do autor é incorreto, pois o certo é conceituar o dano "pela sua causa, pela sua origem”, concentrando a atenção sobre o bem jurídico atingido, o objeto da lesão, e não "as consequências econômicas ou emocionais da lesão sobre determinado sujeito".

Ocorre que, como explanado, conceituar o dano ressarcível simplesmente como um detrimento a um bem jurídico é uma noção bastante ampla, que acaba por abraçar também atos meramente ilícitos. A adoção dessa teoria amplia o conceito do dano ressarcível, permitindo que a tutela ressarcitória também seja aplicada para condutas apenas ilícitas sem que tenham provocado um prejuízo. De outro lado, a teoria do dano como violação a um direito subjetivo acaba trazendo um critério muito restritivo, deixando desacobertados os interesses que embora não estejam normatizados, se mostram sérios e legítimos. Trata-se de um modelo individualista e patrimonialista, que não consegue atender os ditames da proteção integral, nem aos interesses difusos e coletivos, marcas da sociedade moderna e massificada.

Portanto, as duas últimas teorias na sistematização de Calvo Costa se mostram mais acertadas e podem ser adotadas em conjunto, pois apresentam uma homogeneidade. $\mathrm{O}$ acerto se encontra no fato de que apresentam parâmetro para distinguir quais situações da vida são apenas um dano em sentido amplo, que não demandam uma tutela ressarcitória, e quais, pelo contrário, configuram um dano ressarcível. Esses critérios, permitem que se delimite o campo de atuação da tutela ressarcitória, mostrando-se, portanto, mais satisfatórios. Nesse sentido, não se tutelam bens em abstrato, mas apenas os que satisfaçam um interesse humano específico ou genericamente protegido, do qual se prove uma consequência prejudicial que mensurará o valor a se indenizar.

\subsection{O direito de autodeterminação informacional no Brasil e a caracterização do dano}

O direito de autodeterminação informacional é extraído do direito de privacidade, mas se distingue e possui autonomia na medida em que, como visto, revela uma forma de expressão da liberdade efetiva e não negativa. Não se trata de uma mera tutela negativa de não se expor, mas confere ao indivíduo o poder de escolher o que será feito de suas informações, trazendo um aspecto efetivo. Para tanto, o legislador possui um importante papel, a fim de introduzir os mecanismos viabilizadores do exercício desse direito. Tal tarefa foi realizada pelo ordenador brasileiro, por meio da Lei 12.414/2011, denominada Lei do Cadastro Positivo, que estrutura uma tutela protetiva específica para a formação do histórico de crédito dos consumidores, pautada nos princípios do conhecimento, transparência e publicidade. 
Assim, a primeira medida é a exigência do consentimento informado do cadastrado, pelo que o art. $4^{\circ}$ requisita a prévia autorização para a abertura do cadastro. Portanto, o legislador concede ao indivíduo o poder de escolher se é oportuno ou não, para a prática de seus atos comerciais privativos, a exposição de suas informações. Garante, assim, que os indivíduos tenham conhecimento acerca do uso de seus dados em arquivos de consumo.

$\mathrm{Na}$ mesma linha diretiva o art. $5^{\circ}$ inciso $\mathrm{V}$ prevê que o cadastrado deve ser informado previamente sobre o armazenamento, a identidade do gestor do banco de dados e o objetivo do tratamento dos dados pessoais, bem como os destinatários dos dados em caso de compartilhamento. Com isso permite que o cadastrado possa exercer um controle sobre a extensão do uso de suas informações pessoais, bem como, se o cruzamento de seus dados segue atendendo as finalidades pelas quais eles foram expostos. Para tanto o inciso VII determina que os dados pessoais presentes no cadastro positivo somente podem ser utilizados para os casos especificados no art. $7^{\circ}$ : análise de risco de crédito, subsídio para a concessão ou extensão do crédito, realização de venda a prazo ou outras operações com risco financeiro ao consulente. E fortalecendo esta previsão, o legislador ainda determinou no art. 15 que as informações somente podem ser acessadas por consulentes que mantiverem ou pretenderem manter relação comercial ou creditícia.

O legislador brasileiro manteve, ainda, a necessidade de autorização expressa nos demais influxos de acesso à informação, requerendo-a também para os casos de compartilhamento de informações (art. $9^{\circ}$ ), bem como para acesso aos dados constantes perante os prestadores de serviços de água, esgoto, eletricidade, gás e telecomunicações (art. 11). E, como um feixe garantidor do poder de autodeterminação, o art. $5^{\circ}$ inciso I da Lei 12.414/2011, prevê também que é direito do cadastrado obter o cancelamento do cadastro, conferindo-lhe a escolha de determinar um limite para que suas informações pessoais possam constar nos cadastros de crédito.

Quanto às medidas de informação, garantindo a transparência, o ordenador confere ao cadastrado o direito de impugnar os dados erroneamente anotada em banco de dados e ter em até sete dias sua correção ou cancelamento e comunicação aos bancos de dados com os quais ele compartilhou a informação. Trata-se de um dever do gestor, conforme o art. $9^{\circ}$ da lei brasileira, de manter atualizadas as informações cadastrais com os quais compartilhou as informações, devendo informar os casos de cancelamento sem qualquer ônus para o cadastrado. A Lei do Cadastro Positivo estabelece, ainda, que as informações de adimplemento não podem constar de bancos de dados por período superior a quinze anos, delimitando a publicidade da 
circulação dos dados, garantindo o seu apagamento também pelo decurso do tempo (direito de esquecimento).

Em síntese, com a Lei 12.414/2011 o ordenamento nacional passa a contar com um regramento específico sobre a matéria, introduzindo restrições à liberdade de configuração dos cadastros positivos ao normatizar a forma pela qual deve se efetuar o armazenamento de dados sobre o adimplemento do cadastro. Tais restrições são administradas pelo cadastrado, a quem se confere o poder de autorizar, fiscalizar e apagar o registro de suas informações.

Verifica-se que o legislador reconheceu a necessidade de proteção do consumidor, estabelecendo não apenas requisitos para a formação e compartilhamento de dados, mas ofereceu mecanismos protetivos para a tutela específica da Selbstbestimmung, para que, por meio de ferramentas de esclarecimento, informação e apagamento de dados, sejam afastadas potencialidades lesivas à privacidade do cadastrado.

Tratam-se de ferramentas essenciais para que o indivíduo possa transitar nas relações negociais, autodeterminando o grau de exposição de suas informações pessoais. As esferas de privacidade passam ser gerenciadas pelo próprio indivíduo, o que deve ser respeitado pelo gestor de dados. Trata-se de uma forma diferente de equalizar os interesses contrapostos, transmudando-se, também, a análise acerca da lesividade nestas relações, na medida em que a ofensa não advém de uma alegação genérica de ofensa à privacidade, mas de uma pontual situação de impraticabilidade do direito de autodeterminação geradora de um dano.

Compondo as duas últimas teorias apresentadas acerca do dano, tem-se que a Lei $12.414 / 2011$ protege o interesse do consumidor, que passa a contar com ferramentas de exercício do seu direito de autodeterminar o uso e extensão de seus dados pessoais. Eventual conduta lesiva por parte do gestor do banco de dados, somente configurará um dano ressarcível caso provoque um prejuízo a este interesse. E o resultado danoso advindo dessa conduta, a ser comprovado, servirá de base para a fixação do quantum indenizatório.

Desta forma, o exercício arbitrário do gestor, por exemplo pela inserção de um dado incorreto, sem resultar um prejuízo efetivo, como a não realização de uma compra ou perda efetiva da chance da realização de um negócio, caracteriza o ilícito previsto no art. 187 do Código Civil (CC), a ensejar o uso de tutela inibitória ou mandamental de remoção da conduta ilícita, o que pode ser feito através dos mecanismos previstos na Lei 12.414/2011.

O legislador criou uma estrutura de gestão responsável, visando o desenvolvimento da política econômica nacional, sem deixar de proteger os direitos dos consumidores, onde as ilicitudes dos gestores de bancos de dados configuram-se sem a necessidade de comprovação da culpa, conforme art. 187 do Código Civil, podendo ser saneadas através da tutela inibitória 
ou mandamental, para implementação dos mecanismos de controle e fiscalização (correção, exclusão, cancelamento de dados pessoais). Por outro lado, caso a gestão cause lesão ao indivíduo que obste a satisfação de seu interesse legítimo, com base no art. 927 do Código Civil, será possível buscar a tutela indenizatória mediante a comprovação do dano ou a perda de uma chance efetiva no mercado. O cadastrado prejudicado com a ausência de conhecimento do registro de seus dados deverá, para fundamentar o pleito ressarcitório, demonstrar que, por decorrência deste fato, houve uma perda significativa no mercado (CACHAPUZ, 2013, p. 226).

Nesse contexto, caracteriza-se o dano ressarcível quando houver um abuso ou cerceamento dos mecanismos de conhecimento, transparência e publicidade, que inviabilizem o exercício do direito de autodeterminação informacional resultando em uma consequência nefasta, a qual servirá de parâmetro de quantificação do valor a reparar.

Ocorre que essa noção de configuração de dano não foi assimilada logo após a edição da Lei do Cadastro Positivo. Pelo contrário, depois da sua vigência inúmeras ações indenizatórias foram oferecidas no Judiciário brasileiro, contendo argumentos genéricos de violação à intimidade e privacidade e alegação de ilicitude do sistema de pontuação da análise de crédito, chamada credit scoring, sem a preocupação com a comprovação da ocorrência de um dano efetivo, pela perda de uma oportunidade da realização de um negócio.

Este dado fático demonstra que naquele período a causídica brasileira ainda estava fortemente vinculada à teoria das esferas da privacidade e traz dados concretos das repercussões do movimento que preleciona a dispensabilidade do dano para a fixação da responsabilidade civil. Analisa-se a seguir os argumentos favoráveis e contrários ao movimento e os reflexos dessa linha de pensamento no caso das ações do credit scoring.

\section{Movimento da configuração da responsabilidade civil sem dano: argumentos prós e contra e o reflexo de sua dispensabilidade no contexto dos arquivos de consumo - o caso credit scoring}

O pressuposto do movimento da responsabilidade civil sem dano é a de que a sociedade contemporânea vivencia um novo paradigma, qual seja, o risco, e para tanto, a responsabilidade civil deve assumir outro critério de imputação, a fim de atender aos ditames atuais (HIRONAKA, 2008). Esse paradigma decorre do entendimento de que a revolução industrial e a tecnológica ampliaram as possibilidades de risco de danos, infligindo aos indivíduos a preocupação não mais com a reparação de um dano, mas com a prevenção e 
precaução de risco de danos (CARRÁ, 2015). Ou seja, o avanço científico, tecnológico e da medicina projetam uma insegurança nos autores sociais, pois desconhecem as repercussões desse progresso com, por exemplo, a introdução de novo medicamento, do uso de uma antena de TV ou da transmissibilidade em redes informatizadas de dados pessoais (LOPEZ, 2010).

A fim de equalizar tal situação, utilizam como argumento motor a manutenção do ideal do justo. Encontram, assim, nas palavras de João Baptista Villela forte inspiração ao referir que "na teoria da responsabilidade civil, o que se procura obter, em última análise, é a restauração de uma igualdade destruída; qualquer que seja o fundamento que se lhe dê - culpa ou risco - é a um resultado igualitário que se objetiva" (1991, p. 489). Sustentam, com isso, que há necessidade da construção de um novo sistema, na medida em que o existente estaria a reclamar uma transformação, pois as soluções teóricas e jurisprudências até aqui desenvolvidas, e ao longo de toda a história da humanidade, encontram-se em crise, exigindo revisão em prol da mantença do justo". E, a partir disso, criam um critério pautado na redução ao máximo o número de danos irressarcíveis, para tornar o número de vítimas cada vez menor, visando que o direito cumpra seu papel "de responsável pela viabilização da justiça e da paz social" (HIRONAKA, 2008, p. 37, 38).

Com base nisso, o movimento altera o foco da responsabilidade civil, que deixa de ter no dano seu critério de imputabilidade, acrescentando a potencialidade de risco de dano como critério de imputação da responsabilidade. A responsabilidade não estaria, assim, a derivar de um dano, mas do risco decorrente de uma conduta humana na vida social. O núcleo da responsabilidade civil seria, assim, a conduta eventual e potencialmente lesiva, onde a configuração ou não de um dano restaria irrelevante (FERNANDEZ JUNIOR; ROSA, 2016).

Neste entender, a responsabilidade civil assume novas funções, eis que passa a prevenir danos, natureza também externada através de sanções dissuasórias e punitivas, trazendo um caráter educativo da reprimenda no fito de estacar condutas potencialmente geradoras de risco. A ideia clássica de que sem dano não há responsabilidade é substituída pela ideia de que a responsabilidade civil também possui natureza preventiva. Considerando que a eficácia jurídica propriamente dita da responsabilização seria a tutela preventiva e inibitória da causação do dano, flexibilizam a premissa histórica de que o instituto teria cunho apenas indenizatório. Desta forma, dois tipos de responsabilidade coexistiriam: a responsabilidade com dano e sem dano (FERNANDEZ JUNIOR; ROSA, 2016).

Lado outro, com especial preocupação quanto aos aspectos de garantia do acesso à justiça e gestão da responsabilidade civil, que não para de se avolumar frente as novas potencialidades lesivas e atribuições de funções, apresentam-se críticas ao movimento. 
Um primeiro ponto que milita em desfavor da tese refere-se à própria evolução histórica da responsabilidade civil e seus limites epistêmicos. Como preleciona Bruno Carrá (2016, p. 1), a indenização civil se vocacionou ao longo dos séculos para a "repreensão do dano e não para sua prevenção direta”. Portanto, a equalização presente é a do (re)equilíbrio causado pela lesão praticada contra o patrimônio ou integridade de um indivíduo.

Relembra o autor que foi a partir da introdução do dano aquiliano (damnum ijuria datum) estabelecido pela Lex Aquilia, que a noção de dano se sobrepõe às demais forma delitivas e começa a ser a base da reparação (CARRÁ, 2015). Isso porque, se exigia "a destruição ou alteração da substancia de um objeto físico, com a decorrente perda ou diminuição de sua funcionalidade", a qual "precisava derivar de um ato humano imediato, ou seja, decorrer de um contato direito do ofensor com o objeto". Tem-se, com isso, não apenas a introdução da noção da culpa, mas uma delimitação da ilicitude civil, posto que não basta a mera transgressão da norma, exigindo a presença efetiva de um dano (CARRÁ, 2015, p. 129).

Desta forma sustenta o autor que a inclusão na responsabilidade civil de instrumentos destinados a prevenir os danos e não a compensá-los, com a tutela inibitória, tem como consequência sistêmica o esvaziamento da diferença entre dano e ilicitude, diferença que permite, por exemplo, estabelecer a responsabilidade administrativa pela infração de trânsito independente da civil, que somente nasceria frente a ocorrência de um dano. Com isso, argumenta que outros ramos jurídicos possuem o locos próprio para aplicar diretamente medidas preventivas, inibitórias e punitivas, devendo ser respeitados os limites epistêmicos da responsabilidade civil, sob pena de seu desaparecimento (CARRÁ, 2015, p. 162).

Ademais, já lecionava Pontes de Miranda (1966, p. 66) que "do ilícito outros efeitos podem decorrer", que não a reparação, ou seja, nem sempre caracteriza responsabilidade civil. Como exemplo, tem-se as previsões da manutenção da posse, as ações cominatórias e a própria legítima defesa da posse. Ocorre que, por esse movimento todos esses efeitos distintos da reparação ficariam remetidos à responsabilidade civil, gerando "uma expansão extraordinária e pouco controlável” do instituto (ALBUQUERQUE JÚNIOR, p.98).

Nas críticas de Rui Stoco (2017, p. 177), outro limite que se pode apontar está no próprio sistema normativo em vigor no Brasil, posto que pressupõe um dano. É o que se percebe da leitura do art. 186 do Código Civil, do qual se conclui que "não basta a violação de um direito; impõe-se que essa violação cause dano".

Trabalham, assim, os autores com argumentos que limitam o campo da responsabilidade civil, seja de ordem evolutiva, epistêmica ou normativa, especialmente por perceber que a teoria da responsabilidade civil sem dano traz por consequência a ampliação da 
própria noção de responsabilidade civil, que passa a ser chamada para atuar em situações que até então lhe eram estranhas. Isso repercute diretamente no volume de demandas indenizatória que podem ser opostas perante o Judiciário. Como aponta Cavalieri (2015, p. 215), “acompanhando as estatísticas, pode constatar-se que grande parte dos casos que hoje chegam aos tribunais (...), envolve de alguma forma responsabilidade civil, o que evidencia a desmensurada ampliação das questões sobre a matéria”.

As ações do cadastro positivo são um exemplo notório dessa preocupação. Só no Juizado Especial Cível da Capital/SC, a partir de 2013 ingressaram aproximadamente 150 mil ações repetitivas contra a empresa SERASA. Apenas no mês de janeiro de 2014 foram distribuídas 73 mil destas ações repetitivas (SANTA CATARINA, 2016).

Com essas ações é possível verificar concretamente que a insegurança provocada pelo risco tem sido projetada para dentro de pleitos indenizatórios. É que sem conhecer mais detidamente a sistemática e com a então recente publicação da Lei 12.414/2011, argumentouse que o uso dos dados pessoais para a avaliação do crédito seria uma hipótese de violação dos direitos à intimidade e privacidade. Percebe-se que o argumento central residiu na ilicitude da conduta, sem a preocupação com a demonstração da ocorrência de um dano efetivo, com a não realização de um negócio por uma avaliação equivocada, com dados incorretos ou sensíveis, por exemplo. Atacava-se a ilicitude e abusividade do método de avaliação, com alegações genéricas de violação à privacidade. A mera possibilidade de estar no cadastro e de seu perfil poder sofrer uma avaliação foi motivo suficiente para que se buscasse o acesso à justiça por meio de uma ação indenizatória.

A matéria foi então objetivo de análise no Superior Tribunal de Justiça, por meio do REsp $n^{\circ}$ 1.419.697-RS, no qual o Ministro Sanseverino, então relator, identificou que a discussão acerca da ilicitude da prática do credit scoring seria, assim, o ponto central para o deslinde do feito. Nesse sentido, verificou que inexiste antijuridicidade ou ilicitude no uso do sistema matemático, ao considerar que se trata de uma prática usual e lícita da relação negocial, consistindo em um método de avaliação de risco de concessão de crédito.

E, assim, identificando que a Lei 12.4141/2011 estabeleceu os contornos procedimentais para a gestão dos cadastros positivo com medidas específicas para tutelar o consumidor, os estendeu aos sistemas de pontuação e considerou que a "simples circunstância" de atribuição de uma nota insatisfatória para determinada pessoa, "não acarreta, por si só, um dano moral”, mas ocorrerá se não forem oportunizadas "informações claras acerca dos dados utilizados nesse cálculo estatístico", ou, ainda, "se a nota atribuída ao risco de crédito decorrer da consideração de informações excessivas ou sensíveis”. Em conclusão, pontuou o Ministro 
que, no mais, "para a caracterização de um dano extrapatrimonial, há necessidade de comprovação de uma efetiva recusa de crédito, com base em uma nota de crédito baixa por ter sido fundada em dados incorretos ou desatualizados" (BRASIL, 2014). Portanto, reconheceu que o dano ressarcível se configura em face da lesão aos mecanismos do direito de autodeterminação informacional, do qual se comprove um prejuízo, que será in re ipsa apenas no caso de informações excessivas ou sensíveis.

Com a decisão a matéria foi sedimentada, não se tendo mais notícias de novas insurgências quanto a sistemática com repercussão massificada, de forma a se permitir concluir que a decisão estancou a insegurança que na população então se manifestava. Passase a conhecer a sistemática do método e também ao próprio conteúdo e proposta da Lei do Cadastro Positivo, a qual contém mecanismo de tutela preventiva e remoção de ilícito no caso de equívoco ou incorreção de dados (art. $5^{\circ}$, III). Familiarizando-se com o método e com a própria noção da Selbsbestimmung, inicia-se a conscientização do indivíduo de que ele possui esse direito de autodeterminação do uso de seus dados, podendo além de determinar a extensão da circulação de seus dados (aceitando, controlando, exigindo correção ou cancelamento de seu cadastro), se beneficiar da finalidade idealizada pelo legislador, a do estabelecimento de uma relação de crédito responsável.

\section{Conclusão}

Como visto, nota-se que o fator da insegurança, provocado pelo progresso social, se encontra enraizados nos autores sociais na contemporaneidade. A fim de assimilar o risco de possíveis danos, percebe-se uma abertura cada vez maior das possibilidades de sua configuração, avolumando o uso da tutela ressarcitória para as mais variadas situações do cotidiano. E para além disso, começam a crescer movimentos que a fim de equalizar a insegurança, diminuindo ao máximo o número de vítimas irresarcíveis, deixam de colocar o dano como foco da reponsabilidade civil, atribuindo-lhe um novo critério de imputação, pautado no risco da potencialidade lesiva da conduta.

O reflexo de tal movimento tem sido percebido no Judiciário, que passa a contar com um contingente cada vez maior de demandas ressarcitórias, tornando árdua a tarefa de uma prestação jurisdicional célere e efetiva. Este fator vem a prejudicar a almejada manutenção do justo com a equalização da insegurança. Por conta disso, críticos à corrente apontam para a existência de limites do campo de incidência de responsabilidade civil, demonstrando que o ordenamento jurídico possui mecanismos aptos a tutelar ocorrência de ilicitudes. É, assim, com 
a edição da Lei 12.414/2011 que se introduziu no cenário brasileiro um regramento tutelar específico para a proteção dos dados pessoais dos consumidores, conferindo-lhes, ainda, uma nova forma de administrar o influxo de suas informações, por meio do direito de autodeterminação informacional. Todavia, a insegurança e o medo quanto à nova sistemática se sobrepuseram, em um primeiro momento, na dinâmica social o que repercutiu diretamente na responsabilidade civil, que foi requisitada de forma massificada nas Cortes de Justiça.

Conforme todo o exposto, percebe-se que o papel do direito, a que, portanto, a responsabilidade civil deve contribuir, se projeta para estancar o sentimento de insegurança presente nas interações sociais. E nesse contexto, a percepção mais clara e precisa de quando dentre as inúmeras ocorrências de danos configuram um dano ressarcível, permite que as relações sociais se desenvolvam de forma mais segura. Denota-se, que após a análise do caso no Superior Tribunal de Justiça, pautada na imprescindibilidade da configuração de um dano específico e efetivo, o risco até então percebido na sociedade foi assimilado e substituído pela crescente aferição do exercício da Selbstbestimmung. Portanto, a apresentação de uma forma mais clara de quando se tem por caracterizado o dano ressarcível parece ter contribuído para contornar os sentimentos de insegurança sobre sua ocorrência, o que permite a reflexão, de que a sede dos esforços e estudos devam recair sobre a análise do dano, a fim de e permitir que a responsabilidade civil encontre sua medida e extensão na contemporaneidade. Em tal medida, espera-se aqui ter contribuído para a disseminação do conceito e caracterização do dano sobre o direito de autodeterminação informacional no ordenamento jurídico brasileiro.

\section{Referências bibliográficas}

ALBUQUERQUE JÚNIOR, Roberto Paulino de. Notas sobre a Teoria da Responsabilidade Civil sem Dano. Revista de Direito Civil Contemporâneo, v. 6, n. 3, jan./mar, 2016.

AMARAL, Francisco. Direito civil: introdução. 5. ed. rev., atual. e aum. Rio de Janeiro: Renovar, 2003.

BRASIL - Superior Tribunal de Justiça. Recurso Especial no 1.419.697- RS. (2013/03862850). Recorrente: Boa Vista Serviços S/A. Recorrido: Anderson Guilherme Prado Soares. Relator: Ministro Paulo de Tarso Sanseverino. Brasília, 12 de novembro de 2014. Disponível em: $<$ https://ww2.stj.jus.br/processo/pesquisa/?termo=1 
419697\&aplicacao=processos. ea\&tipoPesquisa=tipoPesquisaGenerica\&chkordem $=$ DESC\&c hkMorto=MORTO $>$. Acesso em: 16 jan. 2017.

BUNDESDATENSCHUTZGESETZ. Disponível em: <https://www.gesetzeiminternet.de/bdsg_1990/index.html>. Acesso em: 10 ago. 2017.

CACHAPUZ, Maria Cláudia. Os bancos cadastrais positivos e o tratamento à informação sobre (IN)Adimplemento. Revista AJURIS, v. 40, n. 131, set. 2013a.

CALVO COSTA, Carlos A. Daño resarcible. Buenos Aires: Hammurabi, 2005.

CARNELUTTI, Francesco. Il danno e il reato. 2. Milão: CEDAM, 1930.

CARRÁ, Bruno Leonardo Câmara. Responsabilidade Civil sem dano: uma análise crítica: limites epistêmicos a uma responsabilidade civil preventiva ou por simples conduta. São Paulo: Atlas, 2015.

CAVALIERI FILHO, Sergio. Programa de responsabilidade civil. 12. ed. São Paulo: Atlas, 2015.

DIAS, Aguiar. Da Responsabilidade Civil. 11 ed., Rio de Janeir: Renovar, 2006.

DEUTSCHER BUNDESTAG. Disponível em: <https://www.bundestag. de/parlament/aufgaben/rechtsgrundlagen/grundgesetz/gg_01/245122 >. Acesso em: 10 ago. 2017.

EIRAS, Agostinho. Segredo de justiça e controlo de dados pessoais informatizados. Coimbra: Coimbra, 1992.

FERNANDEZ JUNIOR, Enio Duarte; ROSA, Renata Martins da. Por uma responsabilidade civil afeta a condutas e não às consequências - Sim, é possível uma responsabilidade civil sem danos. Juris Plenun, Caxias do Sul, v. XII, n. 71, set. 2016. 
HIRONAKA, Giselda Maria Fernandes Novaes. Responsabilidade Pressuposta Evolução de Fundamentos e de Paradigmas da Responsabilidade Civil na Contemporaneidade. Revista Jurídica: órgão nacional de doutrina, jurisprudência, legislação e crítica judiciária, v. 56, n. 364, fev. 2008.

HOFFMANN-RIEM, Wolfgag. Offene Rechtswissenschaft, München: Mohr, 2010.

LOPEZ, Tereza Ancona. Princípio da precaução e evolução da responsabilidade civil. São Paulo: Quartier Latin, 2010.

MARTINS-COSTA, Judith. Comentários ao novo Código civil, volume V, tomo II: do inadimplemento das obrigações. Rio de Janeiro: Forense, 2003.

MIRANDA, Pontes. Tratado de Direito Privado. Parte Especial. Tomo LIII. Direito das Obrigações: fatos ilícitos e responsabilidade. Atualizado por Rui Stoco. São Paulo: Revista dos Tribunais, 2012.

MIRANDA, Pontes. Fontes e evolução do direito civil brasileiro. 2. ed. Rio de Janeiro: Forense, 1981.

NORONHA, Fernando. Direito das obrigações. São Paulo: Saraiva, 2013.

ORGAZ, Alfredo. El daño resarcible. Buenos Aires: Depalma, 1967.

SANSEVERINO, Paulo de Tarso Vieira. Princípio da Reparação Integral: indenização no Código Civil. São Paulo: Saraiva, 2010.

SANTA CATARINA. Poder Judiciário. Fórum Eduardo Luz distribui de forma eletrônica 73 mil ações do Serasa. Disponível em:

$<\mathrm{http}$ ://app.tjsc.jus.br/noticias/listanoticia!viewNoticia.action?cdnoticia=29457>. Acesso em: 2 maio 2016.

STOCO, Rui. Responsabilidade civil sem dano: falácia e contradição. Revista dos Tribunais, São Paulo, v. 106, n. 975, p. 173-184, jan. 2017. 
ZANNONI, Eduardo. A. EI daño em la responsabilidade civil. 3. ed. Buenos Aires: Astrea, 2005.

ZAVALA DE GONZÁLEZ, Matilde María. Resarcimiento del daño moral. Buenos Aires: Astrea, 2009.

VILLELA, João Baptista. Para além do lucro e do dano: efeitos sociais benéficos do risco.

Repertório IOB de Jurisprudência, São Paulo, n. 22, nov. 1991. 


\title{
O CONVALESCIMENTO DA POSSE PRECÁRIA NAS MODALIDADES EXTRAORDINÁRIAS DE USUCAPIÃO
}

\author{
Karina Pinheiro de Castro \\ Centro Universitário Una
}

\begin{abstract}
Resumo
O presente trabalho tem por objetivo demonstrar a possibilidade do convalescimento da posse precária para fins de usucapião, a despeito da ausência de tal previsão no art. 1.208 do Código Civil de 2002. Para tanto, utilizaram-se como métodos de pesquisa científica a análise bibliográfica e jurisprudencial; e, como técnica argumentativa, o arcabouço principiológico constitucional. Abordaram-se os aspectos legais da posse, tais como a interversão e a função social; o instituto da usucapião e suas principais características. Por fim, conclui-se pela possibilidade do convalescimento da posse precária na usucapião extraordinária e extraordinária especial.
\end{abstract}

Palavras-chave: Posse precária, usucapião, convalescimento da posse injusta.

\begin{abstract}
Resumen/Résumé
This current paper has the objective of showing the possibility of recovery of precarious possession for usucaption, despite the absence of this provision in Article 1208 of the Civil Code of 2002. For this purpose, a bibliographic and jurisprudential analysis was used as method of scientific research and the framework of constitutional principles as argumentative technique. Legal aspects of possession, such as the intervention and the social role, the usucaption regiment and its main characteristics were discussed. Finally, we concluded the possibility of regaining the precarious possession by extraordinary and special extraordinary adverse possession.
\end{abstract}

Keywords/Palabras-claves/Mots-clés: Precarious possession, adverse possession, recovery of unfair possession. 


\section{Introdução}

O escopo do presente estudo é a análise doutrinária, legislativa e jurisprudencial acerca da possibilidade de convalescimento da posse precária para fins de aquisição da propriedade pela usucapião, especificamente nas modalidades extraordinária e extraordinária especial ou qualificada, transmudando-a em posse ad usucapionem, em contraponto ao que estabelece o art. 1.208 do Código Civil de 2002 e ao entendimento doutrinário até então prevalecente.

O referido dispositivo legal prevê o convalescimento da posse violenta e da posse clandestina, uma vez cessados os atos que ensejaram os vícios que as maculam. Contudo, em uma interpretação a contrario sensu, não admite o convalescimento da posse precária, o que inviabilizaria, em uma análise sistêmica, a aquisição da propriedade por usucapião pelo possuidor precarista.

O fundamento fático-jurídico do legislador baseia-se no aspecto subjetivo da posse precária, eis que se trata de posse própria obtida com abuso de confiança e conseqüente má-fé e, por tal razão, não pode, em tese, ser convalidada. Ao passo que a posse violenta e a posse clandestina - duas outras espécies de posse injusta - uma vez cessados os atos de violência e clandestinidade, admitem o convalescimento, conforme dicção do supracitado artigo.

Nessa linha de intelecção legislativa, a hermenêutica construída por muitos doutrinadores durante muito tempo - e ainda mantida por uma parcela considerável deles - era no sentido de que o vício da precariedade é indelével e, portanto, inapto a validar a posse daquele que abusou da confiança do legítimo possuidor para adquiri-la, tampouco para fins de usucapião.

Nesta perspectiva, o ponto fulcral do presente trabalho cinge-se à aferição dos argumentos jurídicos, fáticos e sociais que respaldam a possibilidade do convalescimento da posse precária para fins de usucapião, sobretudo nas modalidades extraordinária e extraordinária especial, como forma de garantia a direitos fundamentais constitucionais, tais como a moradia e a dignidade da pessoa humana, bem como a observância de um arcabouço principiológico, como o princípio da boa-fé objetiva e o princípio da função social da posse, em detrimento da imperatividade legal.

Em razão da vasta incidência dessa situação fática nas relações jurídicas brasileiras mais comuns como locação, compra e venda, comodato, usufruto e alienação fiduciária, exemplificativamente, buscou-se apresentar uma proposta de solução jurídica, amparada em análises doutrinária, jurisprudencial e principiológica que desbordam às normas positivadas. 
Foram abordados os institutos jurídicos da posse, da usucapião, bem como seus desdobramentos, conseqüências e efeitos jurídicos tais como as características da posse $a d$ usucapionem, a interversão unilateral da posse, os princípios da função social da posse e da boa-fé objetiva no intuito de se perquirir fundamentos favoráveis à aquisição da propriedade pelo possuidor precarista por usucapião.

Para tanto, buscou-se uma análise hermenêutica, principiológica, bibliográfica e jurisprudencial, como métodos de pesquisa científica, visando, assim, a atingir o objetivo almejado de análise crítica do art. 1.208 do Código Civil e do entendimento doutrinário ainda majoritário, em que pesem o respeito e notoriedade de tais juristas.

\section{Da posse}

\subsection{Conceito e teorias}

O conceito de posse, longe de se pretender esgotá-lo, pode ser compreendido pelo poder de fato que uma pessoa exerce sobre a coisa, amparado ou não, por títulos ou formalidades, exteriorizado por meio do exercício de uma ou algumas faculdades dominiais sobre ela e que acarretam efeitos na órbita jurídica, tais como proteção possessória, indenização pelos frutos e benfeitorias e a usucapião, um de seus principais efeitos.

Sua controvertida origem - tem-se admitido sua base romana - deu causa a uma variada gama de teorias que buscam defini-la. Dentre as quais, destacam-se as duas de maior repercussão: a teoria subjetiva de Friedrich Karl Von Savigny e a objetiva de Rudolf Von Ihering, ambos juristas alemães, professor e aluno, respectivamente, que muito contribuíram com a cultura jurídica em todo o mundo, notadamente o estudo do complexo instituto da posse.

Pela teoria subjetiva de Savigny, a posse é um poder de direito traduzido na conjugação de dois elementos: o corpus e o animus. O corpus é o poder fático, poder físico sobre a coisa, ou seja, o elemento material da posse. O animus, por sua vez, é "a intenção de ter a coisa para si, de exercer sobre ela o direito de propriedade" (TARTUCE, 2015, p. 28).

Sob uma análise crítica essa teoria não explica a condição dos locatários, arrendatários, comodatários, dentre outros, pois falta-lhes o animus domini nessas condições, ante a ausência da intenção de se tornarem proprietários; o que lhes retiraria a condição de possuidores.

Contudo, a teoria subjetiva de Savigny foi a precursora em reconhecer a autonomia do direito possessório e se aplica, indiscutivelmente, na posse ad usucapionem cujas características serão abordadas adiante. Com efeito, para fins de aquisição da propriedade pelo instituto da 
usucapião, em qualquer de suas modalidades, exige-se o animus domini, vale dizer, a convicção de ser o dono da coisa, quando presente a boa-fé do possuidor ou a mera vontade de tê-la como sua propriedade, quando o possuidor age de má-fé, mas com a intenção de se tornar titular do bem.

Por sua vez, a teoria objetiva de Ihering defende que a posse é o exercício de fato de um ou alguns dos poderes dominiais, tais como uso e fruição, independentemente do elemento subjetivo animus.

Apesar de sua subordinação ao exercício de um ou alguns dos poderes do proprietário, quer pelo próprio proprietário quer por outrem que não seja detentor, a objetividade da teoria se revela na ausência do elemento animus para sua configuração. Nesse viés intelectivo, percebe-se que a teoria objetiva, adotada pelo Código Civil de 2002, acertadamente reconhece como possuidores os locatários, comodatários, arrendatários, usufrutuários, o titular do direito real de laje recentemente reconhecido, enfim, todos aqueles possuidores diretos que adquirem a posse em virtude de relações jurídicas de direito obrigacional ou real.

Importante ressaltar que Ihering considera, em sua teoria, que o elemento anímico da vontade não tem o condão de, por si só, modificar o título da posse. O possuidor não pode interna e unilateralmente modificar seu título. Contudo, como será visto adiante, esse elemento anímico atrelado a atos externos inequívocos do possuidor poderão, conforme o caso, alterar o caráter de sua posse.

Vale ressaltar, nesse contexto, o entendimento do mestre Caio Mário da Silva Pereira, segundo o qual "nem todo estado de fato, relativamente à coisa ou à sua utilização, é juridicamente posse", eis que, em determinadas situações previstas em lei "não passa de mera detenção" (PEREIRA, 2006. p. 17)

A detenção, poder físico desprovido de qualificação jurídica, ocorre em situações eleitas pelo legislador conforme se infere dos artigos 1.208 - objeto de análise crítica do presente trabalho - e 1.198, ambos do Código Civil, abaixo transcritos, quais sejam: o poder físico sobre uma coisa em decorrência de subordinação e cumprimento de ordens ou de mera permissão e tolerância, situações que afastam a incidência dos efeitos jurídicos da posse como a usucapião, por exemplo.

Art. 1.198. Considera-se detentor aquele que, achando-se em relação de dependência para com outro, conserva a posse em nome deste e em cumprimento de ordens ou instruções suas. Parágrafo único. Aquele que começou a comportar-se do modo como prescreve este artigo, em relação ao bem e à outra pessoa, presume-se detentor, até que prove o contrário. 
Art. 1.208. Não induzem posse os atos de mera permissão ou tolerância assim como não autorizam a sua aquisição os atos violentos, ou clandestinos, senão depois de cessar a violência ou a clandestinidade (BRASIL, 2002).

Nesse aspecto, vale destacar a principal diferença entre posse e detenção, como menciona Sílvio Rodrigues, segundo o qual da detenção "não defluem conseqüências de ordem jurídica", por sua vez "a posse é relação de fato que gera efeitos no campo do direito", dos quais destaca-se, repita-se, a usucapião. (RODRIGUES, 2003, p. 51)

Em uma concepção clássica e tradicional, a posse pode ser definida como um estado de fato, uma situação em que uma pessoa exerce poder físico e material sobre uma coisa, por meio de uma ingerência socioeconômica, independentemente de uma causa formal, ao contrário da propriedade cuja aquisição decorre de atos de registro, usucapião e outras formas previstas em lei.

Nesta perspectiva, pontuam Nelson Rosenvald e Cristiano Chaves de Farias:

\begin{abstract}
Observamos que o fenômeno da posse ingressa no Direito através de três vias: (a) posse real - seria a posse decorrente da titularidade da propriedade ou de outro direito real (v.g. usufruto, superfície); (b) posse obrigacional - é a posse que advém da aquisição do poder sobre um bem em razão de relação de direito obrigacional (v.g., locação, comodato); (c) posse fática - também chamada de posse natural, exercitada por qualquer um que assuma o poder fático sobre a coisa, independentemente de qualquer relação jurídica real ou obrigacional que lhe conceda substrato, sendo suficiente que legitimamente seja capaz de utilizar concretamente o bem. . (ROSENVALD; FARIAS 2015, p. 47)
\end{abstract}

Nesse sentido, extrai-se da diç̧ão do art. 1.196 CC/2002 - que adotou a teoria objetiva de Ihering - a definição da posse como sendo o exercício pleno ou não de alguns do poderes inerentes à propriedade. Nos dizeres de Flávio Tartuce, "basta a presença de um dos atributos da propriedade para que surja a posse. Em outras palavras, pela atual codificação, todo proprietário é possuidor, mas nem todo possuidor é proprietário.” (TARTUCE, 2015, p. 29).

Contudo, em uma concepção contemporânea, as teorias clássicas da posse não são mais suficientes para defini-la, eis que seus preceitos já não atendem aos princípios de um Estado Democrático de Direito, em que pese a contribuição que proporcionaram para a tutela possessória e para a autonomia da posse em relação à propriedade.

O CC/2002 manteve a concepção clássica do CC/1916, abstendo-se de agregar ao seu conceito a função social da posse como requisito indispensável à concretização de direitos fundamentais assegurados constitucionalmente. 
Sobre tal ponto, passamos à análise da função social da posse como requisito indispensável à sua configuração como meio de garantia aos valores constitucionais.

\subsection{Função social da posse}

A visão patrimonialista e individualista da propriedade preconizada pelo $\mathrm{CC} / 1.916$ foi perdendo força durante o século XX, restando-se superada atualmente. A constitucionalização do Direito Civil ocorrida em decorrência do advento da Constituição da República Federativa do Brasil de 1988 propiciou novos contornos ao direito de propriedade e, consequentemente, à posse ao exigir do proprietário e do possuidor a função social como um dever perante a coletividade.

O absolutismo de direitos privados como a propriedade, o contrato e a família cedeu lugar às transformações sociais, despindo-os do caráter individualista em prol de um bem maior: a satisfação de interesses coletivos - característica essencial de um Estado Democrático de Direito - em detrimento de uma satisfação egoística e única de seus titulares.

A função social da propriedade é um direito subjetivo metaindividual expressamente previsto no art. $5^{\circ}$ XXII da $\mathrm{CF} / 88$ e encontra-se regulamentada em vários dispositivos da codificação civil, destacados adiante. Em relação à posse, apesar da ausência de regramento próprio, sua disciplina está implícita ao princípio constitucional da propriedade como cláusula geral, eis que, conforme visto alhures, a posse é o exercício de um ou alguns dos direitos da propriedade, como o uso e a fruição da coisa.

A função social, em uma visão constitucionalista, é considerada como um dever do proprietário e do possuidor de imóveis urbanos e rurais para com a coletividade. Constitui uma obrigação de conferir ao bem uma destinação econômica e dele extrair ao máximo seu potencial econômico.

Exemplificativamente, um lote ocioso não cumpre a função social. Necessário que seja edificado, utilizado com vistas à contribuição do desenvolvimento urbano. Um terreno rural improdutivo, por sua vez, também não cumpre sua função social. Da mesma forma, desatende a função social quando, a teor do que dispõe o art. $186 \mathrm{CF} / 88$, a propriedade rural não preserva o meio ambiente, não observa as normas relativas às relações de trabalho dos empregados que nele prestam labor e que não seja explorado de modo a favorecer o bem-estar destes e do seu proprietário. 
Art. 186. A função social é cumprida quando a propriedade rural atende, simultaneamente, segundo critérios e graus de exigência estabelecidos em lei, aos seguintes requisitos:

I - aproveitamento racional e adequado;

II - utilização adequada dos recursos naturais disponíveis e preservação do meio ambiente;

III - observância das disposições que regulam as relações de trabalho;

IV - exploração que favoreça o bem-estar dos proprietários e dos trabalhadores. (BRASIL, 1988)

A teoria da posse-social, cujo principal defensor foi o francês Raymond Saleilles, teve origem na função social da posse como fenômeno indissociável de sua concepção.

Para Saleilles, a configuração do instituto da posse encerra não apenas a apropriação pelo homem sobre a coisa e o exercício dos poderes dominiais, tal como preconiza Ihering, mas, notadamente, o atendimento ao anseio social pela produtividade da terra, a moradia, a sustentabilidade, a preservação do meio ambiente e o bem-estar não apenas do proprietário e do possuidor, mas da sociedade em geral. Não basta, portanto, a apropriação (o ter), mas a destinação (o ser). (SALEILLES, 1894, p. 175-176.)

Merece destaque o brilhante legado sobre a noção da posse e sua função social deixado pelo saudoso ex-ministro do STF, Teori Zavascki, à comunidade jurídica:

\footnotetext{
Por função social da propriedade há de se entender o princípio que diz respeito à utilização dos bens, e não à sua titularidade jurídica, a significar que sua força normativa ocorre independentemente da específica consideração de quem detenha o título jurídico de proprietário. [...].

A função social da propriedade (que seria melhor entendida no plural, 'função social das propriedades'), realiza-se ou não, mediante atos concretos, de parte de quem efetivamente tem a disponibilidade física dos bens, ou seja, do possuidor, assim considerado no mais amplo sentido, seja ele titular do direito de propriedade ou não, seja ele detentor ou não de título jurídico a justificar sua posse. (ZAVASCKI, 2002, p. 844).
}

Nesse viés argumentativo, vale ressaltar que a função social da posse é prestigiada pelo Código Civil, sobretudo no regramento acerca do instituto da usucapião, em várias de suas modalidades, como a usucapião extraordinária especial e ordinária especial previstas, respectivamente, nos parágrafos únicos dos artigos 1.238 e 1.242. O possuidor usucapiente que cumpre a função social tem a seu favor a redução dos prazos prescricionais de 15 para 10 anos, na modalidade extraordinária especial e de 10 para 5 anos, na modalidade ordinária especial. Sem contar que na usucapião especial ou constitucional, seja urbana ou rural, a função social é exigida como requisito indispensável à sua configuração.

Trata-se de um prêmio ao possuidor usucapiente que cumpre a função social, que cultiva, habita, planta, preserva o meio ambiente, enfim, contribui com a sociedade ao mesmo 
tempo em que busca sua própria realização. Tal prêmio é a referida redução do prazo prescricional, facilitando-lhe a aquisição da propriedade pela usucapião.

Nesse ínterim, destaca-se a ideia do Enunciado número 492 aprovado na V Jornada de Direito Civil de 2011 do Conselho da Justiça Federal:

\footnotetext{
A posse constitui direito autônomo em relação à propriedade e deve expressar o aproveitamento dos bens para o alcance de interesses existenciais, econômicos e sociais merecedores de tutela (CONSELHO, 2012).
}

Portanto, o imóvel não tem mais uma função individual e absoluta, não se presta mais a atender às necessidades apenas do seu titular, mas de toda uma sociedade. Pode-se afirmar que há uma troca na relação jurídica do homem para com a coletividade, uma reciprocidade de deveres na medida em que a sociedade tem a obrigação de respeitar a propriedade alheia, mas o proprietário tem, em contrapartida, o dever de dar destinação econômica ao seu bem de modo a contribuir com o desenvolvimento social.

\subsection{Da posse precária}

Dentre as várias classificações da posse, para fins desse estudo, destaca-se apenas a sua classificação no que pertine aos seus possíveis vícios. O art. 1.200 CC/2002 trata de critérios objetivos ao classificar a posse, quanto aos vícios, em justa e injusta.

Preconiza que justa é a posse que não for violenta, clandestina ou precária. A contrario sensu, a posse viciada pela violência, clandestinidade e precariedade é injusta e, portanto, sujeita à tutela possessória a ser pleiteada pelo legítimo possuidor.

Os vícios violência (física ou moral) e clandestinidade - assim entendida como uma posse obtida às escondidas do legítimo possuidor, sob artimanhas - são vícios que maculam a posse em sua origem.

A posse precária, por sua vez, em seu sentido elíptico, é uma posse originariamente justa e legítima, mas que se torna injusta em um momento a posteriori, vale dizer, quando surge o dever de restituí-la, o possuidor se abstém, mantendo-se com o poder físico sobre a coisa e convertendo-a em uma posse injusta.

A posse precária é, portanto, obtida por meio do abuso de confiança ou de direito daquele a quem fora cedida pelo legítimo possuidor. 
Nessa esteira de raciocínio, acentuam Nelson Rosenvald e Cristiano Chaves de Faria entendem que a posse precária "resulta do abuso de confiança do possuidor que indevidamente retém a coisa além do prazo avençado para o término da relação jurídica de direito real ou obrigacional que originou a posse.” (FARIAS; ROSENVALD, 2015, p. 108)

Merece destaque o juízo do ilustre e clássico civilista Clóvis Beviláqua:

O vício, naturalmente, não está na precariedade da posse. É perfeitamente lícita a concessão da posse de uma coisa, a título precário, isto é, para ser restituída, quando o proprietário a reclamar. O vício está na recusa da restituição, a que se obrigara o possuidor. (BEVILÁQUA, 1941, p. 51)

O exemplo mais clássico citado pelos doutrinadores é o do contrato de comodato que, malgrado tenha sua vigência chegado ao fim, o comodatário se mantém no imóvel, ato que se configura esbulho pelo vício da precariedade, eis que sua posse se torna injusta e, portanto, sujeita aos meios de tutela possessória contra tal ato espoliativo.

A posse precária, antes de se tornar como tal, é uma posse justa, conforme mencionado e, portanto, despida de animus domini, eis que lastreada no desdobramento possessório por meio do qual o possuidor direto reconhece o domínio do proprietário, então possuidor indireto.

Contudo, a questão crucial do presente trabalho reside nas situações que permeiam o fenômeno da interversão da posse, ou seja, sua transmudação a partir do momento em que o possuidor direto se recusa a restituir a coisa ao possuidor indireto, tornando-se precarista. Ocorreria, nessa hipótese, a inversão também do animus? Poderia o precarista, a partir daí, ter animus domini para fins de configuração da usucapião a despeito da impossibilidade preconizada no art. 1.208 retrotranscrito? Eis o ponto fulcral a ser desenvolvido nos tópicos a seguir.

\subsection{Interversão da posse}

O vocábulo "interversão" significa inversão. Relativamente ao instituto da posse, é admitida, excepcionalmente, a inversão de seu caráter, ou seja, a inversão do título do possuidor.

Conforme estabelece o art. 1.203 da codificação civil, o fenômeno conhecido como interversio possessionis é previsto de forma excepcional. O que prevalece é o princípio da continuidade do caráter da posse, salvo prova em contrário: 
Art. 1.203. Salvo prova em contrário, entende-se manter a posse o mesmo caráter com que foi adquirida (BRASIL, 2002).

A interversão é considerada um modo de aquisição da posse que tanto pode ser bilateral, e, portanto, derivada, a exemplo, do locatário que possuindo em nome alheio compra o imóvel locado e passa a possuir em nome próprio, fenômeno conhecido como traditio brevi manu; como também unilateral e originária.

A hipótese de interversão unilateral e originária ocorre a partir do momento em que o possuidor direto rompe ilicitamente a relação jurídica que deu causa à aquisição da sua posse, transformando-a de uma subordinada a uma posse insubordinada. Esse rompimento se revela no plano fático por meio da prática de atos de oposição ao domínio alheio, bem como no plano subjetivo por meio da inversão do animus.

Nesse sentido, o precarista passa a não mais se subordinar à vontade do possuidor indireto, que na maioria das vezes é o proprietário, para assumir uma vontade própria em relação à coisa, ainda que contrariamente ao ordenamento jurídico, dando origem a uma nova causa possessionis. Vale dizer, de má-fé! Má-fé no sentido de ter ciência que possui injustamente, o que não significa sua ausência de vontade de agir como se fosse o proprietário ou de se tornar proprietário.

Enquanto que a interversio possessionis bilateral é indiscutível, a possibilidade da inversão unilateral é alvo de intensas discussões doutrinárias e jurisprudenciais.

Contudo, o art. 1.203 do Código Civil nos permite concluir que é admissível a prova da alteração do caráter da posse, eis que não há restrição se referida alteração deva ser unilateral ou bilateral.

Importa registrar a interpretação relativa ao referido dispositivo legal pelo Enunciado 237 da III Jornada de Direito Civil do Conselho de Justiça Federal:

É cabível a modificação do título da posse - interversio possessionis - na hipótese em que o até então possuidor direto demonstrar ato exterior e inequívoco de oposição ao antigo possuidor indireto, tendo por efeito a caracterização do animus domini. (CONSELHO, 2009)

Defende-se no presente trabalho a possibilidade dessa interversão unilateral, eis que a presunção da continuidade do caráter da posse é relativa. Por conseguinte, havendo prova do rompimento da causa primitiva de aquisição da posse, nova causa possessionis é admitida. Tal prova é extraída de atos inequívocos e externos do possuidor somados a um elemento psíquico: o animus domini. 
Dessa forma, não obstante não seja o proprietário do ponto de vista jurídico-formal, o precarista age como se fosse, apresenta-se como tal com ânimo de definitividade, em que pese estar agindo contrariamente ao direito do verdadeiro proprietário, então legítimo possuidor.

Nesse sentido, importa registrar o escólio de Pontes de Miranda:

O caráter inicial que a causa possessionis originária imprime à posse projeta-se no futuro até que esta seja substituída por uma causa possessionis diversa, o que se dá com a inversão do título possessório, fenômeno que instaura uma nova posse, com características próprias, e, ipso facto, inconfundível com a que lhe antecedeu. (MIRANDA, 1971)

A possibilidade de alteração do caráter da posse foi reconhecida pelo STJ no julgado de relatoria do Ministro Barros Monteiro, cuja ementa se transcreve:

RECURSO ESPECIAL No 143.976 - GO (1997/0056962-4 USUCAPIÃO EXTRAORDINÁRIA. PROMESSA DE VENDA E COMPRA. TRANSMUTAÇÃO DA POSSE, DE NÃO PRÓPRIA PARA PRÓPRIA. ADMISSIBILIDADE. RELATOR: MINISTRO BARROS MONTEIRO - 14/06/2004 "O fato de ser possuidor direto na condição de promitente-comprador de imóvel, em princípio, não impede que este adquira a propriedade do bem por usucapião, uma vez que é possível a transformação do caráter originário daquela posse, de não própria, para própria" (REsp nº 220.200-SP). Recurso especial não conhecido. (BRASIL, 2004)

Pelo fato da posse justa, a priori, ter se transmudado em injusta pelo vício da precariedade configurando-se, assim, o esbulho, o proprietário deve se valer dos meios de tutela possessória ou petitória, conforme o caso, sob pena de sua inércia durante o transcurso do prazo prescricional culminar na alteração do caráter subjetivo da posse e, assim, na configuração da usucapião em seu desfavor.

Nesse sentido, importa ainda ressaltar que além da interversão unilateral da posse pelo possuidor precário, considera-se perdida a posse pelo proprietário e possuidor indireto, quando cessa seu poder de fato sobre o bem, embora contra sua vontade, a teor do que dispõe o art. $1.223 \mathrm{CC}$.

Uma vez perdida a posse, incumbe-lhe tomar as medidas judiciais cabíveis para retomá-la, sob pena do tempo fulminar sua propriedade pelo instituto da usucapião.

\section{O instituto da usucapião}

\subsection{Definição e características da posse ad usucapionem}


O instituto da usucapião tem origem no direito romano, na Lei das Doze Tábuas e, não obstante sua existência tão remota consolidou-se ao longo dos anos, rompendo fronteiras e consagrando-se no ordenamento jurídico dos países do mundo inteiro.

O vocábulo usucapião é oriundo do latim usu capio que significa tomar a coisa pelo uso.

No sistema jurídico brasileiro, a usucapião é considerada uma forma de aquisição originária da propriedade móvel ou imóvel, por meio do exercício incontestado e prolongado da posse durante um lapso temporal determinado em lei. Constitui, assim, um prêmio ao possuidor ao contemplá-lo com a aquisição do bem pelo mero exercício de fato da posse e, ao mesmo tempo, uma sanção ao proprietário inerte pela perda desse bem.

O regramento dogmático do instituto da usucapião encontra-se disposto nos artigos 1.238 a 1.244 do Código Civil/02 dos quais se retiram as suas variadas espécies construídas doutrinária e jurisprudencialmente, sem prejuízo da usucapião coletiva prevista no Estatuto da Cidade e no Estatuto da Terra e da usucapião extrajudicial inserida na Lei de Registros Públicos pelo CPC 2015 e alterado pela Lei 13.465/2017.

Independentemente da modalidade de usucapião aplicável ao caso concreto, é indispensável que a posse seja revestida das características ad usucapionem, caso contrário, não se configura a aquisição pela usucapião.

Dentre os requisitos da posse ad usucapionem, destacam-se os requisitos formais indispensáveis ao objetivo do presente trabalho, quais sejam: a pacificidade da posse, a continuidade do seu exercício e o animus domini.

A posse deve ser mansa e pacífica durante todo o tempo exigido pela lei que varia conforme a modalidade de usucapião. Portanto, o seu exercício não pode ser contestado pelo proprietário ou por quem seja legitimamente um possuidor, como um usufrutuário, por exemplo.

Cumpre ressaltar que a forma de oposição à posse exercida pelo usucapiente deve se dar judicialmente por meio das ações possessórias ou petitórias no interregno legal pelos legitimados ora mencionados. Além disso, exige-se que tais ações sejam exitosas, caso contrário, não terão o condão de descaracterizar a pacificidade e mansidão que prevalecem a favor do possuidor.

A continuidade, por sua vez, manifesta-se pelo exercício ininterrupto da posse, podendo ser descaracterizada por atos de abandono do possuidor por um tempo relevante. 
E, por fim, o animus domini (ânimo de dono). Tal requisito tem um caráter subjetivo, interno, ligado à intenção do possuidor. E tal intenção é perscrutada por atos exteriores que denunciam seus propósitos em relação ao bem possuído.

Conforme exposto no tópico 2.4, pode-se afirmar que o ânimo de dono varia conforme a boa ou a má-fé do possuidor. Na posse ad usucapionem, o possuidor de boa-fé ignora o vício que macula sua posse e age em relação ao bem acreditando ser o legítimo proprietário. $\mathrm{O}$ possuidor de má-fé, por sua vez, age na intenção de tornar-se proprietário, eis que ciente do vício objetivo da sua posse: o da violência, da clandestinidade ou da precariedade.

Estes são, portanto, os pressupostos da posse passível de usucapião.

Infere-se, consequentemente, que a boa-fé do possuidor não é exigida em diversas modalidades de usucapião tal como a usucapião extraordinária, razão pela qual, ainda que de má-fé o possuidor, desde que alcançados os demais requisitos legais, logrará êxito em uma ação de usucapião, por meio da qual terá declarado judicialmente seu direito à propriedade.

\subsection{Pressupostos legais da usucapião extraordinária e da usucapião extraordinária especial}

Dentre as diversas modalidades, para o presente trabalho destacam-se a usucapião extraordinária, prevista no caput do artigo $1.238 \mathrm{CC} / 02$ e a extraordinária especial regulamentada no parágrafo único do referido artigo.

Art. 1.238. Aquele que, por quinze anos, sem interrupção, nem oposição, possuir como seu um imóvel, adquire-lhe a propriedade, independentemente de título e boafé; podendo requerer ao juiz que assim o declare por sentença, a qual servirá de título para o registro no Cartório de Registro de Imóveis.

Parágrafo único. O prazo estabelecido neste artigo reduzir-se-á a dez anos se o possuidor houver estabelecido no imóvel a sua moradia habitual, ou nele realizado obras ou serviços de caráter produtivo (BRASIL, 2002).

A diferença entre ambas as modalidades está na forma do exercício da posse: simples ou qualificada. Pela posse simples, caracterizadora da usucapião extraordinária, o possuidor exerce faticamente um ou algum dos poderes inerentes à propriedade pelo prazo de quinze anos, independentemente de outros requisitos. Ou seja, o mero exercício da posse ad usucapionem no referido prazo.

A posse qualificada manifesta-se pelo exercício de fato acrescido à função social pela moradia do possuidor ou pela realização de obras e serviços de caráter produtivo no imóvel usucapiente. O legislador prestigiou o possuidor que exerce função social ao reduzir o prazo para dez anos, ensejando-se, assim, como o próprio nome diz, uma modalidade especial de 
usucapião: a usucapião extraordinária especial. Sua peculiaridade é o cumprimento da função social em observância a um princípio basilar do Código Civil, o da socialidade.

O princípio da socialidade é uma das manifestações da constitucionalização do Direito Civil, que afastou interesses exclusivistas e patrimoniais para a promoção de uma igualdade formal na construção de um novo paradigma: o bem estar social.

No instituto da usucapião, a função social está presente na modalidade extraordinária especial cujo prazo é reduzido contemplando-se, assim, o possuidor que mora, que planta, que cultiva, que trabalha e preserva o meio ambiente.

Ressalte-se que a função social se faz presente também na usucapião especial, urbana ou rural, regulamentada, respectivamente, nos arts. 1.240 e 1.239 do Código Civil. Tratam-se de modalidades de usucapião lastreadas no texto constitucional e criadas para garantir a moradia a possuidores de pequenas áreas, quais sejam, até $250 \mathrm{~m} 2$ e 50 hectares.

Impende registrar que a boa-fé que, diga-se de passagem, trata-se da boa-fé subjetiva, constitui requisito apenas na modalidade de usucapião ordinária, conforme dispõe o art. 1.242 do diploma civil, em cujo parágrafo único a função social também se encontra determinada.

De tais assertivas, pode-se inferir que a função social encontra-se disciplinada em todas as modalidades de usucapião como requisito fundamental e representa uma forma de garantia do direito fundamental à moradia, ao meio ambiente equilibrado, ao desenvolvimento social.

\section{O convalescimento da posse precária nas modalidades de usucapião extraordinária e extraordinária especial}

Um dos temas de grande discussão em matéria de posse é a possibilidade (ou não) do convalescimento da posse precária.

Como visto, o fenômeno da interversão da posse consiste na inversão do seu caráter, seja pela bilateralidade e alteração do título do possuidor ou, conforme se defende no presente trabalho, também pela alteração unilateral do possuidor que, por meio de atos exteriores inequívocos demonstra seu novo animus em relação à posse, não mais reconhecendo o domínio alheio.

Contudo, boa parte da doutrina (por todos a professora Maria Helena Diniz), não admite o convalescimento da posse precária para fins de usucapião ao preferir seguir a literalidade do art. 1.208 do CC/02, acima transcrito. 
Tal dispositivo permite a aquisição da posse por atos violentos ou clandestinos, uma vez cessadas a violência e a clandestinidade, mas não prevê a aquisição da posse precária. $\mathrm{O}$ fundamento originário de tal vedação é que a posse precária é obtida pelo abuso de confiança perpetrado pelo possuidor contra o então legítimo possuidor indireto, o proprietário.

Refuta-se, pois, tal ilação, pois o dispositivo legal invocado não deve ser aplicado, indistintamente, a todas as situações fáticas que, em tese, subsumem-se à sua regra. Com efeito, em uma visão contemporânea e alicerçada nos preceitos constitucionais, o Direito não pode afastar a possibilidade da transformação do caráter da posse precária, eis que, em determinadas hipóteses, a inércia do proprietário não deverá prevalecer em detrimento do possuidor (ainda que precário), mas cumpridor da função social do imóvel.

Nessa linha de pensamento, citam-se os doutrinadores Flávio Tartuce, Marco Aurélio Bezerra de Melo e Francisco Eduardo Loureiro que, por todos, tem o seguinte entendimento:

Na realidade, bem observadas as coisas, a posse precária, enquanto posse viciada, não se altera, tanto que o esbulhado pode retomar a coisa; todavia, a mudança de comportamento do precarista, pela inversão do título, permite a transformação da posse ad interdicta para posse ad usucapionem. (LOUREIRO 2009, p.1118)

Em outras palavras, deve-se admitir o convalescimento da posse precária, pois a partir da interversão, inicia-se um novo marco temporal ao longo do qual o proprietário terá a oportunidade de se valer dos meios de tutela possessória ou petitória contra o possuidor precarista a fim de evitar a consumação da usucapião.

Sua desídia em ajuizar as ações reipersecutórias cabíveis não pode ser desconsiderada pelo ordenamento jurídico, pois seria privilegiar sua incúria em prejuízo do possuidor que, não obstante seja primitivamente um possuidor injusto, age com o imóvel com zelo, morando, edificando, plantando, realizando benfeitorias, ou seja, cumprindo a função social da propriedade.

Oportuno o posicionamento de Nelson Rosenvald e Cristiano Chaves de Faria ao dispensarem em seu manual de Direito Civil um capítulo cujo título é "Função Social da Posse e o Direito de Moradia” do qual são extraídos os seguintes trechos:

Aprecia-se a atuação fática de um possuidor sobre a coisa que o titular patrimonial desvinculou de qualquer função social. [...] Aqui, o possuidor adquire individualidade e busca acesso aos bens que assegurem a si e a sua família o passaporte ao mínimo essencial. São casos em que a propriedade recebe função social, mas quem a concede não é o proprietário, porém um possuidor. (ROSENVALD; FARIAS 2018, p. 77-78) 
Neste aspecto, o tratamento jurídico conferido ao possuidor a título precário deve ser feito com cautela, afastando-se o critério subjetivo preconizado pela intenção legislativa que se infere do art. 1.208 em questão.

Ademais, a subjetividade que ainda lastreia erroneamente a aplicação do art. 1.208 não se sustenta em relação à posse ad usucapionem. Com efeito, para a configuração da usucapião extraordinária e extraordinária especial (enfoque do presente trabalho) não se exige o requisito boa-fé, vale dizer, ainda que de má-fé, o possuidor poderá usucapir se cumpridos os demais pressupostos.

Exige-se, sim, o animus domini! Assim, o precarista, ainda que de má-fé, poderá usucapir por tais modalidades e a ausência de animus domini enquanto em vigor a relação jurídica com o proprietário oriunda do desdobramento da posse não mais prevalecerá, eis que a interversio possessionis dará origem a uma nova causa possessionis, essa sim, com animus domini.

Nesse sentido, afirma o magistrado e doutrinador Carlos Roberto Gonçalves que "[T]al posse, em virtude da nova causa possessionis, tornar-se-ia capaz de conduzir à usucapião, iniciando-se a contagem do prazo a partir dessa inversão." (GONÇALVES, p. 73)

Sob esse prisma, verifica-se inegável contrassenso legislativo ao não se permitir o convalescimento da posse precária, mas tão somente da posse violenta e clandestina, ambas também adquiridas de ma-fé.

Compreende-se que na posse precária, originariamente justa, a coisa é entregue ao possuidor com base na confiança, quebrada pelo vício ao não ser restituída. Porém, não se pode negar que na posse violenta ou clandestina há uma violação tão ou ainda maior a direitos subjetivos do proprietário.

Oportuna a transcrição do mestre civilista Sílvio de Salvo Venosa (2009), segundo o qual "embora o conceito de posse injusta seja objetivo, a posse violenta, ao menos em sua origem, vem imbuída da mácula da má-fé." (p. 64)

E continua ao afirmar que:

Há violência na posse de imóvel se nele adentramos, expulsando o possuidor ou quem lá se encontre ou impedimos o possuidor de ali ingressar ou retornar. Destarte, existe também violência quando alguém invade propriedade onde não encontrou pessoa alguma, violência esta que se concretiza a partir do momento em que o possuidor despojado seja impedido de nela reentrar. (VENOSA, 2009, p. 64) 
Utilizando-se de tal raciocínio, relevante ressaltar que nada impede que uma posse possa ser viciada objetivamente e não subjetivamente. A recíproca é verdadeira. Portanto, a posse pode ser justa e de má-fé, a exemplo da posse obtida por meio dos vícios do consentimento do negócio jurídico, tal como o dolo ou coação. Da mesma maneira que pode ser injusta por quaisquer dos três vícios objetivos que ensejam o esbulho (violência, clandestinidade ou precariedade), mas ser de boa-fé por ter sido transferida a um terceiro que desconheça a origem maculada da posse.

Em todas essas situações descritas, à exceção da precariedade por expressa disposição legal ora rechaçada, é possível ao possuidor adquirir a propriedade pela usucapião.

Sob tal raciocínio, a prevalecer a literalidade (que impede a aquisição da posse precária) da lei em situações nas quais embora não tenha havido violência, nem aquisição da posse por meios ardis como nas hipóteses dos vícios de consentimento acima citados, é ignorar a aplicação dos princípios constitucionais e, portanto, da justiça ao caso concreto. De fato, não se pode negar que a posse violenta ou clandestina também são revestidas de um caráter abusivo, não da confiança, mas do direito alheio.

Compete ao proprietário, pois, em todas as situações, valer-se dos meios de tutela jurisdicional para a defesa de seu bem. Mantendo-se inerte durante todo o transcurso dos prazos da usucapião, ao contrário do possuidor que cumpre a função social, deve-se admitir o convalescimento da posse, ainda que precária, para tal fim.

\section{Conclusão}

Conforme se depreende de todo o exposto, pode-se afirmar que o princípio da função social da propriedade consagrado no texto constitucional apresenta-se como um marco axiológico dos valores sociais em contraponto aos valores individualistas de outrora.

Por tal razão, a posse, em virtude de seu largo alcance social, tende a cumprir cada vez mais o papel preconizado pelo texto constitucional em atendimento aos direitos fundamentais individuais tais como a moradia e a propriedade, bem como o direito fundamental coletivo da função social.

Nessa ordem de ideias, a função social da posse pode se configurar a partir de uma transformação da má-fé subjetiva do possuidor precário em boa-fé objetiva quando atribuir uma destinação positiva à coisa. $\mathrm{O}$ abuso de confiança por ele praticado transmuda-se em uma expectativa de direito e confiança legítima com decorrer do tempo. 
Mediante tal comportamento positivo durante a longa trajetória das modalidades extraordinárias de usucapião, deve prevalecer o princípio da boa-fé objetiva, acarretando-se, assim, a supressão (supressio) do direito proprietário inerte e o surgimento (surrectio) do direito do possuidor precário que, ao cumprir a função social da posse com animus domini, legitima sua expectativa de direito à aquisição do bem pelo instituto da usucapião.

Sob o mesmo raciocínio, oportuno registrar que o vício subjetivo da má-fé impede a aquisição da propriedade pela usucapião tão somente nas modalidades ordinárias previstas no art. $1.242 \mathrm{CC} / 02$ e seu parágrafo único, eis que exigem a boa-fé como pressuposto à sua configuração.

Nas demais modalidades, sobretudo nas extraordinárias às quais foi dado maior enfoque no presente trabalho, não se exige o requisito subjetivo da boa-fé, razão pela qual, outros pressupostos fáticos e objetivos devem prevalecer para caracterização da usucapião. E o principal pressuposto é a função social da posse.

Percebe-se, pois, do ponto de vista social, que a teoria possessória de Raymond Saleilles lastreada na socialização da posse é a que mais contribui com a efetivação do direito fundamental coletivo da função social consagrado constitucionalmente. Para ele, o possuidor é o que exerce domínio econômico e sustentável sobre a coisa, ou seja, é aquele que planta, que mora, que cultiva, que constrói, que cuida, enfim, que faz do bem o lugar de desenvolvimento próprio e de sua família.

Vale ressaltar que a função social da posse e a boa-fé objetiva são princípios de ordem pública que visam a garantir direitos que não se restringem à esfera privada e individualista do proprietário.

Em determinadas situações concretas os princípios se soprepairam às normas positivadas por serem cláusulas gerais, abertas e que, portanto, permitem uma adequação à consecução dos fins pretendidos pelo texto constitucional.

Conclui-se que o art. 1.208 do Código Civil de 2002 merece uma releitura à luz dos referidos princípios constitucionais, para que esse preceito estanque e não permissivo do convalescimento da posse precária seja, enfim, superado.

Da mesma forma, o art. 1.203 CC que consagra o princípio da continuidade do caráter da posse também deve ser interpretado casuisticamente e relativizado com base nos preceitos constitucionais, pois nem sempre o caráter da posse se manterá o mesmo com que fora adquirida. 
Portanto, deve prevalecer o direito de aquisição da propriedade pelo instituto da usucapião pelo possuidor que, a despeito de ser primitivamente precário, cumpre a função social da posse por longos anos, em detrimento do direito individual do proprietário inerte.

Defende-se, portanto, a abdicação da aplicação literal dos dispositivos legais ora discutidos e de um rigor formal do título de proprietário, bem como a prevalência do atendimento às necessidades sociais, do direito à moradia como sucedâneo da dignidade da pessoa humana, do interesse coletivo e do desenvolvimento social como lastros fundamentais do Estado Democrático de Direito - tal como preconiza a Carta Magna brasileira de 1988 - e, assim, da consagração de um verdadeiro Direito Civil-Constitucional.

\section{Referências bibliográficas}

BEVILÁQUA, Clóvis. Direito das Coisas. 1 v. Posse, propriedade, direitos autoraes, direitos reaes de gozo sobre coisas alheias. Rio de Janeiro: Livraria Editora Freitas Bastos, 1941.

BRASIL. Constituição (1988). Constituição da República Federativa do Brasil. Brasília. DF: Senado, 1988.

BRASIL. Lei no 6.015, de 31 de dezembro de 1973. Dispõe sobre os registros públicos, e dá outras providências. Disponível em:

$<$ http://www.planalto.gov.br/ccivil_03/leis/L6015original.htm>. Acesso em: 03 set.2017.

BRASIL. Lei no $\mathbf{~ 1 3 . 1 0 5}$, de 16 de março de 2015. Institui o Código de Processo Civil.

Disponível em: <http://www.planalto.gov.br/ccivil_03/_ato2015-2018/2015/lei/113105.htm>. Acesso em: 03 set.2017.

BRASIL. Lei no $\mathbf{0} \mathbf{1 0 . 4 0 6}$ de 10 de janeiro de 2002. Institui o Código Civil. Disponível em: $<$ http://www.planalto.gov.br/ccivil_03/leis/2002/110406.htm>. Acesso em 10 mar.2016.

BRASIL. Lei n. 3.071, de 1 de janeiro de 1916. Código Civil. Disponível em: $<$ http://www.planalto.gov.br/CCIVIL/leis/L3071.htm>. Acesso em: 18 de jan. 2018. 
BRASIL. Superior Tribunal de Justiça. Recurso Especial 143.976 - GO. Rel. Ministro Barros Monteiro. 14/06/2004. Disponível em: <https://ww2.stj.jus.br/processo/ revista $/$ documento $/$ mediado/ componente $=$ ATP \&sequencial $=1187954 \&$ num_registro $=19970$ $0569624 \&$ data $=20040614 \&$ tipo $=5 \&$ formato $=P D F>$. Acesso em: 06 set.2017.

CONSELHO de Justiça Federal. Enunciado 492. Disponível em: $<$ http://www.cjf.jus.br/cjf/CEJ-Coedi/jornadas-cej/v-jornada-direitocivil/VJornadadireitocivil2012.pdf/view>. Acesso em: 04 ago.2017.

CONSELHO de Justiça Federal. Enunciado 237. Disponível em: <http://www.cjf. jus.br/enunciados/enunciado/461>. Acesso em: 04 ago.2017.

FARIAS, Cristiano Chaves de; ROSENVALD, Nelson. Curso de Direito Civil. 11 ed. São Paulo: Editora Atlas, 2015.

FARIAS, Cristiano Chaves de; ROSENVALD, Nelson. Curso de Direito Civil. 14 ed. São Paulo: Editora Atlas, 2018.

GONÇALVES, Carlos Roberto. Direito Civil Brasileiro. v. 5. 4 ed. São Paulo: Saraiva, 2009.

LOUREIRO, Francisco Eduardo. Código Civil comentado: doutrina e jurisprudência. Coordenador: César Peluso. 3. ed. rev. e atual. São Paulo: Manole, 2009.

MIRANDA, Pontes de. Tratado de Direito Privado - Parte Especial - Tomo x, Direito das Coisas: Posse. 3 ed. Rio de Janeiro: Editor Borsoi, 1971.

PEREIRA, Caio Mário da Silva. Instituições de Direito Civil. Rio de Janeiro: Forense, 2015.

PEREIRA, Caio Mário da Silva. Instituições de Direito Civil. Volume IV. Direitos Reais. 19 ed. Rio de Janeiro: Forense, 2006. 
PEREIRA, Caio Mário. Instituições de Direito Civil, v. 1, 9 ed., Rio de Janeiro: Forense, 1986.

RODRIGUES, Sílvio. Direito Civil: Direito das coisas, volume 5, 28 ed. rev. e atual. de acordo com o novo Código Civil (Lei n. 10.406, de 10-1-2002). São Paulo: Saraiva, 2003.

SALEILLES, Raymond. Étude sur les eléments constitutifs de la possession. Dijon: Imprimerie Darantie, 1894.

TARTUCE, Flávio. Direito Civil 1. 11 ed. São Paulo: Método, 2015.

TARTUCE, Flávio. Direito das Coisas. 7 ed., São Paulo: Editora Gen, 2015.

VENOSA, Sílvio de Salvo. Direito Civil. Direitos Reais. 9 ed. São Paulo: Editora Atlas, 2009.

ZAVASCKI, Teori Albino. A tutela da posse na Constituição e no projeto do novo Código Civil. In: MARTINS-COSTA, Judith (Org.). A reconstrução do Direito Privado. São Paulo: Revista dos Tribunais, 2002, p. 843-859. 


\title{
PERSPECTIVA DE CONVIVÊNCIA EM REDE FAMILIAR \\ E A ORIGEM GENÉTICA NA RELAÇÃO SOCIOAFETIVA
}

\author{
André Vinícius Guimarães de Carvalho \\ Universidad Autónoma de Asunción \\ Paulo Joviniano Alvares dos Prazeres \\ Universidade Católica de Pernambuco
}

\begin{abstract}
Resumo
O presente estudo busca compreender as características fundamentais e inerentes da personalidade humana. Desta forma, além de indagar sobre o direito de conhecimento da ascendência biológica, abrem-se outras frentes de questionamento. A pesquisa em pauta é composta ainda pelos seguintes objetivos específicos: saber do acesso a verdade genética; entender o grau de relevância para a vida humana quando se trata do conhecimento das características genéticas; averiguar também a necessidade de preservação do núcleo familiar, estabelecido por meio de liames afetivos, essencialmente a segurança, proteção e preservação da filiação socioafetiva; analisar os limites do direito fundamental à identidade.
\end{abstract}

Palavras-chave: origem genética, família, estado de filiação.

\begin{abstract}
Resumen/Résumé
The present study seeks to understand the fundamental and inherent characteristics of the human personality. In this way, besides asking about the right of knowledge of biological ancestry, other fronts of questioning are opened. The research in question is composed of the following specific objectives: knowledge of access to genetic truth; understand the degree of relevance to human life when it comes to knowledge of genetic characteristics; to ascertain also the need to preserve the family nucleus, established through affective ties, essentially the security, protection and preservation of socio-affective affiliation; analyze the limits of the fundamental right to identity.
\end{abstract}

Keywords/Palabras-claves/Mots-clés: genetic origin, family, affiliation status. 


\section{Introdução}

Inicialmente, cabe lembrar que o tema apresentado nesta monografia assume contornos especiais quando resolve abordar a possibilidade de o receptor ter o direito de acessar o material genético que lhe foi doado, de forma irrestrita, a qualquer tempo, assim como provavelmente poder conhecer a identidade do doador.

É certo que será estudada a estrutura da família socio afetiva vinculada a um possível conhecimento da verdade biológica, por parte da prole. Igualmente, para uma melhor compreensão do tema, será tratada a possibilidade da formação de uma rede familiar.

A partir desse contexto é que, seguramente verifica-se a importância da matéria pesquisada, razão pela qual será feita uma abordagem minudente do sigilo do doador versus direito de acesso a origem genética, perpassando pela dignidade humana. Demonstrar sua relevância jurídica e destacar a necessidade do debate, bem como analisar os motivos que geram tantas celeumas a despeito da temática, também são focos dessa monografia.

Assim, é nessa linha de raciocínio que se adentra no primeiro capítulo, o qual apresenta noções conceituais preliminares de filiação e demonstra o desenvolvimento desta no curso do tempo, mostra-se também a diversidade com que era verificada a filiação na Idade Antiga, na Idade Média, na Idade Moderna, até chegar a Idade Contemporânea.

Uma informação a acrescentar é que, ainda, na explanação do capítulo primeiro, à luz da Lei Civil de 1916 e da Lei Civil vigente, assim como, sob a égide da Carta Suprema do Brasil, examina-se didaticamente os tipos de filiação, ou seja, aborda-se a filiação natural, a filiação de tecnologia reprodutiva conceptiva, a filiação assistida, a filiação adotiva e, finalmente, encerra-se o tópico abordando criticamente as questões relacionadas aos direitos e deveres da filiação.

Agora, de maneira mais objetiva, segue-se, então, para enfrentar no segundo capítulo, as celeumas que rondam o direito à identidade genética como um direito fundamental amparado pela Constituição da República Federativa do Brasil.

Com muito mais embasamento jurídico, a partir do princípio da dignidade da pessoa humana, assim como diante dos dispositivos ocultos, que possibilitam a interpretação teleológica da tutela de direitos essenciais (vida, liberdade, personalidade), ao qual se destina a Lei Maior preservar, e que nunca lhe diminuem de valor, é que se conceitua o direito à identidade genética como um direito fundamental. 
Neste capítulo, à guisa de saber, aborda-se, ao mesmo tempo, a proteção legal ao direito à identidade genética, analisa-se o liame biológico, o estado de filho atrelado à paternidade/maternidade responsável e a convivência no esteio da família socioafetiva.

No que concerne à metodologia empregada, esclarece-se que o método de trabalho que prevaleceu foi o raciocínio dedutivo, sem que isso se entenda privação de aplicação do método de raciocínio indutivo. Como métodos auxiliares de procedimento, valeu-se dos métodos histórico e comparativo. Já ao longo do texto, fica evidente a adoção do método de interpretação jurídica.

Por fim, no que se refere aos tipos e técnicas de pesquisa, utilizou-se pesquisa bibliográfica nacional e documental.

\section{Filiação}

Em primeira ordem, cumpre observar filiação a luz do dicionário jurídico da Academia Brasileira de Letras Jurídicas “[...] S. f. (Lat. filiatio) Dir. Civ. Relação existente entre o filho e as pessoas que o geram, provada pelo registro de nascimento, salvo erro de falsidade [...]". (2004, p.396).

Em segunda ordem, no dizer expressivo do dicionário de língua portuguesa Houaiss, tem-se por filiação:

[...] ação ou efeito de filhar. 1 liame que une um indivíduo a seu pai ou a sua mãe 1.1 onomástica dos pais de alguém <na ficha, só falta preencher o campo de f. $>2$ série de indivíduos que descendem diretamente um dos outros; descendência, linhagem, progênie 3 vinculação de alguém ou algo a entidade pública ou particular, partindo político, agremiação etc. $<$ f. partidária $><0$ país fez sua $\mathrm{f}$. à $\mathrm{ONU}>3.1$ ingresso (em uma comunidade qualquer) $<$ f. ao Clube Naval $>4$ sequência, vínculo de coisas que resultam uma de outra ou que apresentam certa interdependência; encadeamento, conexão $<$ f. de ideologias $>5$ JUR relação de parentesco que liga os fillhos aos seus progenitores $[\ldots]$ ( 2001, p.1342).

Cumpre obtemperar, todavia, que o vigente Código Civil no artigo 1.596, ao afirmar que os filhos, havidos ou não da relação de casamento, ou por adoção, terão os mesmos direitos e qualificações, proibidas quaisquer designações discriminatórias relativas à filiação. 
Portanto, admite de forma en passant, isto é, o Digesto Civil trata não só da filiação oriunda da conjunção carnal (consanguínea), mais também da filiação: adotiva, socioafetiva, da filiação assistida homóloga ou heteróloga (consentida previamente pelo marido), in vitro.

O doutrinador Sílvio de Salvo Venosa, em seu magistério, define filiação como sendo: “[...] todas as relações, e respectivamente sua constituição, modificação e extinção, que têm como sujeitos os pais com relação aos filhos" (2006, p. 227).

Por outro lado, Maria Helena Diniz, conceitua filiação, como sendo “[...] vínculo existente entre pais e filhos" (2007, p.41) e prossegue que;

[...] vem a ser relação de parentesco consanguíneo em linha reta de primeiro grau entre uma pessoa e aqueles que lhe deram a vida, podendo ainda (CC, arts. 1.593 a $1.597 \mathrm{e}$ 1618 e s.), ser uma relação socioafetiva entre pai adotivo e institucional e filho adotado ou advindo de inseminação artificial heteróloga. (2007, p. 420-421).

Assim sendo, a procedência da filiação não é o aspecto mais significativo a ser considerado para o Direito contemporâneo, pois, pouco importa se a relação parental familiar (pais e filhos) é decorrente de: filiação consanguínea, ou de outra origem. Verdade seja esta é que nem um tipo de filiação prepondera sobre a outra, ou seja, a legislação brasileira atual preza por todos os vínculos familiares desde que a afetividade esteja presente na relação parental.

Inclusive, assim preceitua a Carta Política em vigor no Brasil, de maneira explícita ela afirma serem proibidas quaisquer designações discriminatórias relativas filiação, já que os direitos são os mesmo e iguais para todos os filhos. In verbis o artigo 227 e seu $\S 6^{\circ}$ da Constituição Federal,

É dever da família, da sociedade e do Estado assegurar à criança e ao adolescente, com absoluta prioridade, o direito à vida, à saúde, à alimentação, à educação, ao lazer, à profissionalização, à cultura, à dignidade, ao respeito, à liberdade e à convivência familiar e comunitária, além de colocá-los a salvo de toda forma de negligência, discriminação, exploração, violência, crueldade e opressão. [...]

$\S 6^{\circ}$ Os filhos, havidos ou não da relação do casamento, ou por adoção, terão os mesmos direitos e qualificações, proibidas quaisquer designações discriminatórias relativas à filiação.

Por tais razões, assim como preceitua o texto constitucional retro mencionado, demonstrado está, a imperiosa a prevalência nas relações familiares dos vínculos de afetividade, 
bem como sendo o afeto o liame mais relevante a ser considerado na família, na sociedade e pelo Direito.

\section{Direito a identidade biológica}

Em sede jurídica, é cristalino no preâmbulo e nos artigos $1^{\circ}$ e $5^{\circ}$, da Norma Ápice, que o respeito à pessoa/personalidade tem guarida no bojo dos direitos fundamentais, seguramente, visando não deixar dúvidas a esse respeito; e em função da dignidade da pessoa humana, é que o legislador constituinte ao instituir o Estado Democrático, e assegurar o exercício dos direitos sociais e individuais, afirma que: a liberdade, a segurança, o bem-estar, o desenvolvimento, a igualdade e a justiça são valores supremos da sociedade brasileira, uma sociedade fraterna, pluralista e sem preconceitos, fundada na harmonia social e comprometida, na ordem interna e internacional, com a solução pacífica das controvérsias.

Em trabalho bibliográfico publicado sobre a filiação socioafetiva e direito à identidade genética, Leila Donizetti, esclarece:

[...] o respeito à pessoa é o marco jurídico básico, o suporte inicial que justifica a existência e admite a especificação dos demais direitos, garantida a igualdade de todos perante a lei (igualdade formal) e a igualdade de oportunidades no campo econômico e social (igualdade material). (2007, p. 73).

Consoante noção cediça, antes de conceituar identidade genética, ainda, nas palavras da escritora Leila Donizetti, urge abordar o conceito de identidade pessoal.

\footnotetext{
"O reconhecimento pela Constituição do direito à identidade pessoal, visando garantir aquilo que identifica cada pessoa como indivíduo, singular e irredutível, compreende duas diferentes dimensões: a) A identidade pessoal tem uma dimensão absoluta ou individual - cada pessoa tem uma identidade definida por si própria, expressão do caráter único, indivisível e irredutível de cada ser humano: cada pessoa é, por isso, uma realidade singular, dotada de uma individualidade que a distingue de todas as demais; b) A identidade pessoal comporta também uma dimensão relativa ou relacional - cada pessoa tem a sua identidade igualmente definida em função de uma memória familiar conferida pelos seus antepassados, assumindo aqui especial destaque os respectivos progenitores, podendo falar-se num "direito à historicidade pessoal".40" (2007, p. 79).
} 
Em virtude das considerações supramencionadas, dessume-se que a identidade genética é tida como um bem jurídico constitucional. Evidente, também, que se discute dentro dessa perspectiva a proteção aos direitos da personalidade, que estão entrelaçados na relação entre identidade genética e identidade pessoal.

Leila Donizetti, após reunir conceitos de diversos autores, define identidade genética nas palavras de Maria de Fátima Freire de Sá, como sendo:

\begin{abstract}
"O conceito de identidade genética traz no seu bojo uma correspondência ao genoma de cada ser humano, ou seja, o fundamento biológico ínsito a cada um [...]. Em outro sentido, o termo identidade genética pode ser designada para caracterizar a mesma constituição genética entre dois ou mais seres. [...] Finalmente, como terceira acepção, vislumbramos o termo identidade genética como nível prévio à identidade pessoal, sendo aquele substrato fundamental desta. Nessa seara, o que importa é saber a origem genética, a verdade sobre a própria progenitura. Também diz respeito à possibilidade de saber ou de se recusar saber sobre diagnósticos e prognósticos de doenças e pesquisas realizadas. Mas não só isso, porquanto a identidade de uma pessoa não se reduz aos seus aspectos genéticos. Também influem na formação pessoal complexos fatores educativos e ambientais, assim como os laços afetivos, sociais, espirituais e culturais, que conservam uma dimensão de liberdade”. 41 (2007, p. 80).
\end{abstract}

Pelas razões aduzidas, indiscutível, no plano da consagração constitucional a tutela deste bem, ocorre, uma identificação socialmente relevante. É de se verificar que a identidade genética contempla um conjunto de bens que integram a consciência jurídica do ordenamento pátrio.

Não é despiciendo observar que, o conceito retro mencionado de identidade genética, preleciona que o genoma de cada ser humano e que suas bases biológicas caracterizam a personalidade da identidade pessoal/ personalidade.

Incontestavelmente, a dimensão do genoma humano possui diferença em cada pessoa, isto é, apresenta-se na compreensão de engenharia genética irreplicável.

Consequentemente, pode-se inferir que a identidade pessoal/personalidade é sinônimo de individualidade genética.

Assim, o conceito de identidade genética conduz a compreensão do seu sentido adequado, na relação entre identidade exclusiva, que conduz a identidade biológica, que se expressa na constituição do código genético único e irrepetível, de cada ser humano, salvo nos casos dos gêmeos monozigóticos ou univitelinos, visto que, necessariamente possuem o mesmo sexo, são idênticos, têm o mesmo genoma, e são "clones naturais" um do outro. 
Nessa senda, a identidade genética é um substrato fundamental da identidade pessoal/personalidade, que por sua vez é a expressão da dignidade do ser humano. A identidade pessoal/personalidade relaciona-se com as características pessoais do indivíduo. (Cf. Leila Donizetti apud Maria Christina Almeida, 2007).

No que se refere à identidade pessoal/personalidade, pontifica Daisy Gogliano, em sua dissertação de mestrado, direitos privados da personalidade em:

[...] direitos subjetivos particulares, que consistem nas prerrogativas concebidas a uma pessoa pelo sistema jurídico e asseguradas pelos meios de direito, para fruir e dispor, como senhor, dos atributos essenciais da sua própria personalidade, de seus aspectos, emoções e prolongamentos, como fundamento natural da existência e liberdade, pela necessidade da preservação e resguardo da integridade física, psíquica e moral do ser humano, no seu desenvolvimento. (1982, p. 363-364).

Convalida esse raciocínio Paulo Luiz Netto Lôbo, ao fazer distinção entre estado de filiação e direito de conhecimento da identidade genética:

O estado de filiação, decorrente da estabilidade dos laços afetivos construídos no cotidiano de pai e filho, constitui fundamento essencial da atribuição de paternidade ou maternidade. Nada tem a ver com o direito de cada pessoa ao conhecimento de sua origem genética. São duas situações distintas, tendo a primeira natureza de direito de família, e a segunda, de direito da personalidade. (2002, p. 53).

$\mathrm{Na}$ verdade, o esforço doutrinário é o de ratificar e conservar o reconhecimento da personalidade, que inclui a identidade pessoal e genética, como um direito personalíssimo, indisponível e imprescritível, que pode ser exercitado sem qualquer restrição, em face dos pais, herdeiros ou terceiros. É indubitável que, sob a ótica da Carta Magna, e somente sob esse viés, deve-se salvaguardar o direito ao conhecimento da própria origem.

Impende ressaltar, entretanto, que se o exercício do direito a identidade genética, por conseguinte a identidade pessoal/personalidade que estiver em possível rota de colisão com o princípio fundamental da dignidade da pessoa humana, estabelecido no artigo $1^{\circ}$, inciso III, da Constituição Federal de 1988, caracteriza afronta ao Estado Democrático de Direito, portanto, impossível de ser albergado juridicamente. Ou seja, o indivíduo que deseje informações de seus dados genéticos, para fins econômicos, patrimoniais e/ou provar novo estado de fíliação não terá guarida do direito. (Cf. DONIZETTI, 2009, p. 124-125). 
Em leitura a voo de pássaro, do parágrafo anterior aquele a princípio apresenta-se paradoxal, visto que o direito a personalidade está assegurado na Carta Política e a dignidade humana é corolário da República Federativa do Brasil. Isto é, o direito a identidade biológica e pessoal possuem ligames intrínsecos com princípio da dignidade humana. Todavia, acontece que, a ninguém é dado a priori o direito de querer conhecer suas origens tão-somente para alcance financeiro, tal atitude soa como algo absurdo, contrário a ética e aos constitucionais que amparam a família, entre eles o princípio da dignidade humana.

Dessa maneira, pergunta-se se em todos os casos assinala violação ao princípio da dignidade da pessoa humana cercear o direito de conhecimento da origem genética? Há desrespeito, por conseguinte, da necessidade psicológica de se conhecer a verdade biológica? Em que circunstâncias pode-se permitir ao indivíduo a inteireza e irrestrito conhecimento da sua identidade genética? A pessoa que por hipótese tenha sido clonada tem o direito de saber a sua origem genética? "Até que ponto a imposição do anonimato dos doadores e receptores de gametas é salutar para a preservação da integridade psíquica do ser humano?” (DONIZETTI, 2009, p. 116).

Além das indagações retro mencionadas, existem inúmeras outras questões controversas, e de início sem respostas, acerca do direito de se ter conhecimento a identidade genética, que geram uma enorme polêmica entre profissionais como: juristas, médicos, psicólogos, sociólogos, educadores, cientistas, et reliqua. é saber como definir o limite de procriação de um filho.

Jorge Shiguemitsu Fujita, ainda, indaga:

Poderá, entretanto, inexistir ligação biológica alguma entre os pais e o filho, na hipótese de reprodução assistida heteróloga bilateral,34 na qual os materiais genéticos foram fornecidos por doador e uma doadora anônimos, com a gestação no útero da esposa ou da companheira, ou no útero de uma mãe substituta. (2009, p. 67).

O direito de conhecimento da origem genética dá margem a perguntas aflitivas e que cinde o mundo jurídico. Leila Donizetti, com a autoridade que lhe é ínsita, posiciona-se:

Ora, permitir ao indivíduo o acesso às informações que lhe dizem respeito nada mais é do que uma das facetas que compõem os direitos da personalidade, razão pela qual deve ser outorgado ao indivíduo que se encontra nessa situação o direito de exigir que referidos dados, tão particulares, lhe sejam transmitidos. (DONIZETTI, 2009, p. 119). 
Paulo Luiz Netto Lôbo, na mesma linha de entendimento de Leila Donizetti, corrobora da assertiva de que a pessoa deve ter irrestrito acesso às informações da sua origem genética, independente das consequências sociais, familiares ou jurídicas que possam advir tais informações.

Assim, posiciona-se Luiz Netto Lôbo:

\begin{abstract}
"As normas de regência e os efeitos jurídicos não se confundem nem se interpenetram. Para garantir a tutela do direito da personalidade, não é necessário investigar a paternidade. $\mathrm{O}$ objeto da tutela do direito ao conhecimento da origem genética é a garantia do direito da personalidade, na espécie, direito à vida, pois os dados da ciência atual apontam para a necessidade de cada indivíduo saber a história de saúde de seus parentes biológicos próximos, para prevenção da própria vida. Não há necessidade de atribuição da paternidade para o exercício do direito da personalidade de conhecer, por exemplo, os ascendentes biológicos paternos do que foi gerado por doador anônimo de sêmen, ou do que foi adotado, ou concebido por inseminação artificial heteróloga. Exemplos como esses demonstram o equívoco em que laboram decisões que confundem investigação de paternidade com direito à origem genética." (2002, p. 53).
\end{abstract}

O direito do conhecimento das origens genéticas está pautado por um conflito de interesses, que envolve: o casal que anseia por um filho, o doador do material genético e a criança gerada que atendeu interesses do casal e do doador. (Cf. DONIZETTI, 2009, p. 122).

Leila Donizetti, ainda, destaca o posicionamento daqueles que são contrários a revelação das informações da sua origem genética, ressalva:

\footnotetext{
"Na outra vertente, têm-se os argumentos favoráveis ao anonimato do doador que, basicamente, se restringem aos interesses amplamente defendidos pela classe médica cuja alegação se firma no raciocínio de que a quebra do anonimato dos doadores implicaria diminuição no número de fornecedores, impossibilitando, de maneira reflexa, o acesso às técnicas de reprodução assistida por aqueles que precisam se beneficiar delas para realizar o desejo de ter um filho.” (DONIZETTI, 2009, p. 124).
}

Por todo o exposto, pertinente é o depoimento da estudante de biologia, Margaret R. Brown, que enfrenta um autêntico drama existencial ao saber sobre sua origem. A jovem foi gerada por meio de fertilização in vitro com a ajuda de um doador anônimo dos Estados Unidos, afirma: 


\begin{abstract}
"Tenho um sonho recorrente: me vejo flutuando em no meio da escuridão enquanto giro cada vez mais rápido em uma região sem nome, fora do tempo, quase não terrenal. Fico angustiada e quero pôr os pés no chão. Mas não há nada sobre o que plantar os pés. Este é meu pesadelo: sou uma pessoa gerada por inseminação artificial com esperma de doador e nunca conhecerei metade de minha identidade.” $(2009$, p. 1).
\end{abstract}

Este caso apenas ilustra que o conhecimento da origem genética envolve meandros complexos, interesses distintos e incompatíveis, portanto, deve o direito posicionar-se no sentido de solucionar todas as implicações que são adversas a vida das partes envolvidas.

Por fim, não se pode deixar de mencionar qual seja a postura que venha a ser adotada pelo ordenamento jurídico brasileiro, ela tem de estar em consonância com a Constituição Federal. Ademais, razoável é que a solução para este imbróglio seja construída em consentâneo com a sociedade civil organizada.

Pelo exposto até então, percebe-se que no Brasil o direito da criança "[...] vindicar acesso aos dados genéticos do doador anônimo de sêmen arquivados na instituição em que se deu a concepção tão-somente para proteger os direitos da personalidade, [...]" (DONIZETTI, 2009, p. 127), encontra guarida nos artigos $1^{\circ}$, III e 225, $\S 1^{\circ}$, II, da Norma Constitucional.

Entretanto, é preciso observar que o amparo legal a despeito do filho ter conhecimento da sua identidade genética é algo controverso e de proteção exígua em termo legislativo no Brasil. O direito ao genoma humano não está explicitamente assegurado ao filho, em contrário busca-se, ainda, proteger o doador, por meio de resolução do Conselho Federal de Medicina, questão a tratar em seguida.

Discorre-se a infertilidade humana como um problema de saúde, com implicações médicas e psicológicas, e a legitimidade do anseio de superá-la é sempre no interesse dos pais, do doador e de terceiro, porém, nunca a favor da criança. A resolução 1358/92, do Conselho Federal de Medicina, após uma série de reuniões declara que:

"I. 1. As técnicas de Reprodução Assistida (RA) têm o papel de auxiliar na resolução dos problemas de infertilidade humana, facilitando o processo de procriação quando outras terapêuticas tenham sido ineficazes ou ineficientes para a solução da situação atual de infertilidade."

Adiante, a referida resolução do Conselho Federal de Medicina, destaca, também que: 
"IV. 3 - Obrigatoriamente será mantido o sigilo sobre a identidade dos doadores de gametas e pré-embriões, assim como dos receptores. Em situações especiais, as informações sobre doadores, por motivação médica, podem ser fornecidas exclusivamente para médicos, resguardando-se a identidade civil do doador."

Nesse sentido Selma Rodrigues Pertterle reitera essa constatação ao afirmar que:

\begin{abstract}
“Também no que concerne à dimensão prestacional do direito à identidade genética, aquela que requer uma intervenção positiva do Estado, na forma de uma prestação jurídica, é dever do Estado legislar detalhadamente sobre a matéria (prestações jurídicas), estabelecendo os mecanismos garantidores da identidade genética do ser humano via legislação infraconstitucional. ${ }^{363 "}$ (2007, p. 118-119).
\end{abstract}

Neste contexto, impõem-se algumas reflexões: será que a resolução 1358/92 do Conselho Federal de Medicina, atende aos ditames constitucionais brasileiros? Ou seja, é uma resolução compatível com o Texto Constitucional? O anonimato do doador não implica em afronta aos direitos e garantias fundamentais resguardado na Constituição Federal? A restrição da identidade genética em face do sigilo da identidade do doador de gametas e pré-embriões viola direitos da personalidade? O doador de material genético age por amor ao seu semelhante ou por algum tipo de recompensa?

Tendo em vista esses aspectos, que de início indicam um possível conflito entre direitos fundamentais, há de examinar o assunto sobre o prisma dos princípios constitucionais e dos supostos direitos absolutos.

Cumpre frisar, sobre direitos absolutos, isto é, direitos que em nenhuma hipótese, podem ser afastados e que são eficazes contra qualquer pessoa, a pertinente colocação de Norberto Bobbio, em a Era dos Direitos, que, com lucidez, enfrenta a temática, desenvolvendo o seu pensamento sobre o assunto partindo da premissa de que não há direito absoluto, bem como não se trata de saber quais e quantos são estes direitos, qual é a natureza; o que deve-se é buscar um modo mais seguro para garanti-los.

[...] direito fundamental de uma categoria de pessoas e o direito igualmente fundamental de uma outra categoria, é preciso distinguir um caso que põe ainda mais gravemente em perigo a busca do fundamento absoluto: [...] Pois bem: dois direitos fundamentais, mas antinômicos, não Podem ter, um e outro, um fundamento absoluto, ou seja, um fundamento que torne um direito e o seu oposto, ambos, inquestionáveis e irresistíveis. Aliás, vale a pena recordar que, historicamente, a ilusão do fundamento absoluto de alguns direitos estabelecidos foi um obstáculo à introdução de novos direitos, total ou parcialmente incompatíveis com aqueles. Basta pensar nos empecilhos colocados ao progresso da legislação social pela teoria jusnaturalista do 
fundamento absoluto da propriedade: a oposição quase secular contra a introdução dos direitos sociais foi feita em nome do fundamento absoluto dos direitos de liberdade. O fundamento absoluto não é apenas uma ilusão; em alguns casos, é também um pretexto para defender posições conservadoras. (1992, p. 104).

Nessa linha de entendimento continua explicando Norberto Bobbio:

Não se trata de saber quais e quantos são estes direitos, qual é a natureza e seus fundamentos, se são direitos naturais ou históricos, absolutos ou relativos, mais sim qual é o modo mais seguro para garanti-los, para impedir que, apesar das solenes declarações, eles sejam continuamente violados. (1992, p. 174).

Marcelo Novelino corrobora com as assertivas de Bobbio ao afirmar que:

Nenhum direito, por mais importante que seja, pode ser considerado absoluto. Todos, inclusive os direitos e garantias fundamentais, encontram limites estabelecidos por outros direitos igualmente consagrados no texto constitucional. A tese da existência de direitos absolutos dificilmente se sustentaria diante da colisão entres dois destes direitos tutelados por indivíduos distintos. A impossibilidade de prevalência de dois direitos absolutos, sem que haja uma cedência recíproca, inviabiliza a adoção deste entendimento. Em virtude da relatividade dos direitos, não se pode estabelecer, em abstrato, uma hierarquia normativa entre eles. Havendo um conflito, apenas diante de um caso concreto será possível concluir acerca de qual deles deverá prevalecer naquela hipótese. (2009, p. 306).

Em virtude dos ensinamentos dos autores retro citados, pode-se inferir que a enumeração constitucional dos direitos fundamentais não é numerus clausus.

Outrossim, o direito à identidade genética é um direito fundamental, já que trata de direito da personalidade. De qualquer sorte, ainda, que o direito à identidade genética não estivesse protegido, o texto constitucional estabelece um mínimo de direitos, mas permite que outros direitos fundamentais sejam estabelecidos pelo legislador, desde que não contrariem princípios já estabelecidos pela Constituição Federal.

Além do mais, os alicerces que sustentam o ordenamento são os princípios jurídicos, que por sua vez são enunciados fundamentais. Neste sentido se posta Luís Roberto Barroso:

Os princípios constitucionais são o conjunto de normas da ideologia da Constituição, seus postulados básicos e seus afins. Dito de forma sumária, os princípios constitucionais são as normas eleitas pelo constituinte como fundamento ou qualificações essenciais da ordem jurídica que institui. (1999, p. 141). 
O postulado da dignidade da pessoa humana é o mais universal de todos os princípios, e representa um dos pilares de sustentação do Estado Democrático de Direito, todavia, não é o único princípio que deve ser inserido na discussão do direito à identidade genética, já que a despeito disso destacam-se princípios de igual relevância que são: da reserva legal, da solidariedade, da proporcionalidade, da razoabilidade, das múltiplas relações familiares, da igualdade absoluta entre os cônjuges e os filhos, do melhor interesse da criança, da afetividade e da integridade do patrimônio genético.

A par disso, descortina-se a falsa aparência de conflito entre direitos fundamentais, princípios e/ou outro dispositivo constitucional, o que é límpido e cristalino é a omissão do legislador brasileiro em legiferar sobre a matéria.

A Lei 11.105/2005, que regulamenta os incisos II, IV e V do $\S 1$ o do art. 225 da Constituição Federal, estabelece normas de segurança e mecanismos de fiscalização de atividades que envolvam organismos geneticamente modificados e seus derivados, cria o Conselho Nacional de Biossegurança - CNBS, reestrutura a Comissão Técnica Nacional de Biossegurança - CTNBio e dispõe sobre a Política Nacional de Biossegurança.

No tocante a proteção jurídica do genoma humano na orbita internacional, inicialmente cabe destacar a Declaração Universal sobre o Genoma Humano e os Direitos Humanos DUGHDH/1997, adotada pela Conferência Geral da UNESCO em sua $29^{\circ}$ sessão no ano de 1997.

Primeiramente, pela abrangência do texto que, num contexto científico e político marcado por questões polêmicas como a manipulação do genoma humano, a clonagem humana e os transgênicos, reafirma princípios e valores intangíveis, Ex. vi Princípio da Dignidade da Pessoa Humana. Nas palavras de Koïchiro Matsuura - Diretor-Geral da UNESCO, a importância histórica DUGHDH/1997:

[...] é em virtude dos inúmeros e diferentes atores envolvidos, graças a diversos fatores: a natureza inerente ao assunto que, como todas as questões éticas, situa-se na interface entre várias disciplinas; a universalidade de seu enfoque, que deverá ser enriquecido por um debate público envolvendo todos os membros da sociedade; a diversidade de contextos econômicos, sociais e culturais nos quais se enraíza o pensamento ético ao redor do mundo. Isso porque a reflexão de cada indivíduo se desenvolve conforme sua própria natureza, plasmada por sua história e suas tradições (1997, p.1). 
A DUGHDH/1997, declara em seu artigo $1^{\circ}$. que o "genoma humano constitui a base da unidade fundamental de todos os membros da família humana bem como de sua inerente dignidade e diversidade. Num sentido simbólico, é o patrimônio da humanidade".

Com muita sapiência, proclama que a todo indivíduo é devido respeito à sua dignidade e aos seus direitos, independentemente de suas características genéticas. Assim como, esta dignidade torna imperativa a não redução dos indivíduos às suas características genéticas e ao respeito à sua singularidade e diversidade. Além do mais, que o genoma humano em seu estado natural não deve ser objeto de transações financeiras.

No que tange aos direitos do indivíduo, declarou, que a pesquisa, o tratamento ou o diagnóstico que afetem o genoma humano, devem ser realizados apenas após avaliação rigorosa e prévia dos riscos e benefícios neles implicados e em conformidade com as exigências da norma legal. Assim como, deve ser respeitado o direito de cada indivíduo de decidir se será ou não informado sobre os resultados da análise genética e das consequências dela decorrentes.

Quanto aos dados genéticos, a DUGHDH de 1997, afirmou que devem ter sua confidencialidade assegurada, de acordo com o estabelecido em Lei. Igualmente, declarou que qualquer dano sofrido resultante direta ou indiretamente, de intervenção sobre o genoma, em conformidade com a legislação nacional ou internacional, a pessoa fará jus à justa indenização. O artigo 9, da Declaração Universal sobre o Genoma Humano e os Direitos Humanos é taxativo na indispensabilidade de proteção dos direitos humanos e das liberdades fundamentais, assim está posto:

Art. $9^{\circ}$ - Visando a proteção de direitos humanos e liberdades fundamentais, limitações aos princípios do consentimento e da confidencialidade somente poderão ser determinadas pela legislação, por razões consideradas imperativas no âmbito do direito internacional público e da legislação internacional sobre direitos humanos. (1997, p. 6).

Referente à pesquisa com genoma humano, reafirmou o artigo 10, que nenhuma pesquisa deve sobre por aos direitos humanos.

Art. $10^{\circ}$ - Nenhuma pesquisa ou suas aplicações relacionadas ao genoma humano, particularmente nos campos da biologia, da genética e da medicina, deve prevalecer sobre o respeito aos direitos humanos, às liberdades fundamentais e à dignidade humana dos indivíduos ou, quando for aplicável, de grupos humanos. (1997, p. 6). 
Da mesma forma, repeli todas as práticas contrárias à dignidade humana, tais como a clonagem de seres humanos, e convoca os países e organizações internacionais competentes a cooperarem na identificação de tais práticas e a tomar, em nível nacional ou internacional, as medidas necessárias para assegurar o respeito aos princípios estabelecidos na presente DUGHDH.

Trata, também, das condições para o exercício da atividade científica, destaca que os Estados devem respeitar e promover a prática da solidariedade relativamente a indivíduos, famílias e grupos populacionais particularmente vulneráveis ou afetados por doença ou deficiência de caráter genético.

Por fim, a DUGHDH, preconiza que todos os países devem adotar medidas apropriadas para divulgar os princípios estabelecidos nela, preferencialmente por intermédio da educação, não sendo possível a via educacional que, sejam utilizados outros meios relevantes e, por meio de medidas adequadas, os Estados devem promover sua implementação, envidando de todos os esforços necessários.

A par da Declaração Internacional sobre os Dados Genéticos Humanos DIDGH/2003, reafirmou os princípios consagrados na Declaração Universal sobre o Genoma Humano e os Direitos Humanos, referindo também a princípios como: da igualdade, justiça, solidariedade, responsabilidade, liberdade de pensamento e expressão e liberdade de investigação.

A DIDGH/2003, preconizou ainda, que a ética deve prevalecer em todos os procedimentos aplicados relacionados à coleta, ao tratamento, a utilização e a conservação dos dados genéticos.

Nessa esteira, surgi a Declaração Universal de Bioética e Direitos Humanos DUBDH/2005, que tem por fim maior tratar das questões éticas relacionadas a medicina, às ciências da vida e às tecnologias aplicadas aos seres humanos, considerando sua abrangência social, legal e ambiental.

Em virtude dessas considerações, fica nítido o reconhecimento pela comunidade internacional e pela Constituição Federal de 1988, do direito a origem genética. Todavia, enfoca-se, que o acesso do filho as suas origens biológicas necessariamente não implicarão no estabelecimento de novas relações de parentescos, assim como, não enseja o surgimento de direito alimentar ou sucessório.

Importa ainda considerar que a relação socioafetiva definida ao longo de uma vida entre filho e pai/mãe registral é calcada na afetividade, enquanto, que o significado do 
conhecimento da identidade genética é sobre a auto compreensão biológica, nada tendo a dizer a respeito do afeto.

A clareza cristalina da ascendência genética na relação socioafetiva, não se configura em garantia de convivência em rede familiar, essa perspectiva no atual contexto social é carregada por uma possibilidade ínfima.

Indubitavelmente, a família contemporânea na qual se insere dignidade humana e a solidariedade, que está lastreada nos contornos constitucionais, “[...] passa a ser compreendido como o privilegiado espaço do afeto e do amor, [...]” (DONIZETTI, 2007, p. 12). A família do presente é um porto seguro de igualdade e justiça, amor e paz, construída com base no carinho, no afeto e no respeito à pessoa humana.

Assim sendo, independente do liame biológico, o estado de filho atrelado à paternidade/maternidade responsável e a convivência diuturna implica no esteio da família socioafetiva. Tanto é assim que Leila Donizetti exemplifica que:

\footnotetext{
Na paternidade socioafetiva, pai não é apenas aquele ligado por um laço biológico. Pai é muito mais. Pai é aquele ligado pelos intensos e inesgotáveis laços de afeto. Aquele que cuida, protege, alimenta, educa, que participa intensamente do crescimento físico, intelectual e moral da criança, dando-lhe o suporte necessário para que se desenvolva como ser humano. (2007, p. 15).
}

Por tudo que foi abordado, entende-se que tão-somente o conhecimento da origem genética, não acarretará na construção de uma rede familiar, o que provavelmente acontecerá nessas situações é um maior fortalecimento das relações afetivas, isto é, crescimento robusto da família socioafetiva.

\section{Considerações finais}

O envolvimento emocional na filiação é ínsito à espécie humana. É bem verdade que a valorização jurídica do amor é uma tendência mais consentânea da sociedade moderna, ou seja, é o direito do presente em termos de relação filiação socioafetiva buscando consagrar de maneira plena o afeto.

Indubitavelmente, a filiação é a fonte primária em que repousa ao menos parte da identidade do sujeito que, por conseguinte, refletirá aos diversos grupos sociais e até na sociedade como um todo. 
Infelizmente, a filiação em determinado contexto histórico da evolução do homem vivenciou um período de negrume jurídico e social, isto é, era atribuída uma distinção odiosa aos filhos. Inclusive, havia capítulos na Lei Civil 3.071/1916, relativos à filiação que tinha cabeçalho do tipo: da filiação legítima; da legitimação; do reconhecimento dos filhos ilegítimos. Assim como, nessa época eram usuais as expressões: filhos de sangue; filhos adotivos; filhos adulterinos; filhos incestuosos, filhos de criação, filhos espúrios e outras.

Neste período, a afetividade encontrava-se renegada aos olhos da lei, filhos eram tãosomente, aqueles ligados a alguém, ou a um casal, pelos laços de consanguinidade ou de parentesco civil.

Acontece que o homem por estar em um constante renovar, sendo concebido, em cada época, como um organismo mais amplo, inclusive, enquadrando-se a inúmeras formas de organização humana, levou o legislador constituinte de 1988 a ampliar a ideia de família, dissociando-a do casamento e reconhecendo como entidade familiar a comunidade formada por qualquer dos pais e seus descendentes, assim como, a união estável entre o homem e a mulher.

É nesse contexto constitucional que surge a igualdade entre os filhos, havidos ou não da relação do casamento, ou por adoção, inclusive, com os mesmos direitos e qualificações, sendo proibidas quaisquer designações discriminatórias relativas à filiação.

Mister se faz ressaltar, que é neste ambiente de evolução do homem, que se ancora o atual Diploma Civil, em vigor desde de janeiro de 2003. O efeito jurídico da filiação é expressivo, isso se denota pela modificação da locução estereotipada, pátrio poder em poder familiar, seguindo-se do reconhecimento da igualdade da filiação, bem como pela adoção como forma de filiação irretratável.

Não se pode deixar de ponderar, que a Lei 10.406/2002, silenciou a respeito da posse de estado de filho, entretanto, tendo por base a Constituição Federal e seus princípios norteadores do Direito de Família, filiação é entrelaçamento de afetividade na mais ampla acepção do termo.

Com efeito, em conexão com a presente realidade social a doutrina pátria no encalço das legislações internacionais, assim como a jurisprudência, acolheu de forma soberana e sapiente a filiação socioafetiva.

Oportuno se torna dizer que as atitudes humanitárias condizentes com a valorização do ser humano como pessoa, que dá suporte a uma nova ordem de pensamento denominada de despatrimonialização da relação familiar, e que contribui de forma significativa para o reconhecimento da filiação socioafetiva. 
Registre-se, assim, que é a luz dos pensamentos supracitados e com enfoque em um Direito de Família-Constitucional, que os direitos da personalidade são vistos en passant, como um bem jurídico de valor essencial no aspecto físico, biológico, moral e intelectual.

Pode-se afirmar, portanto, que, apesar dos inúmeros imbróglios que cercam o direito à identidade genética, a exemplo: do anonimato do doador, do direito patrimonial ou sucessório, da organização de uma rede familiar e outros. A identidade genética é um direito fundamental do indivíduo gerado por meio de material genético proveniente de doação, por conseguinte, deve haver uma renúncia compulsória do sigilo por parte de quem cedeu este material.

Por fim, não se pode olvidar que o direito à identidade genética é diferente do direito do estado de filiação, visto que este é erigido ao longo da convivência, entretanto, aquele se trata do direito ao conhecimento da verdade biológica.

\section{Referências bibliográficas}

BARROSO, Luís Roberto. Interpretação e aplicação da Constituição: fundamentos de uma dogmática constitucional transformadora. 3 eds. São Paulo: Saraiva, 1999.

BOBBIO, Norberto. A era dos direitos. Trad. Carlos Nelson Coutinho. Rio de Janeiro: Campus, 1992.

BRASIL, Código Civil Brasileiro - Lei n ${ }^{0}$ 10.406/2002. $7^{\text {a }}$ ed. São Paulo: Saraiva, 2009.

CASSIRER, Ernst. Ensaio sobre o homem: introdução a uma filosofia da cultura humana. Tradução Tomás Rosa Bueno. São Paulo: Martins Fontes, $1^{\text {a }}$ Edição 1994, $4^{\mathrm{a}}$ tiragem, março de 2005.

DINIZ, Maria Helena. Curso de Direito Civil Brasileiro - 5. Direito de Família. $22^{\mathrm{a}}$ ed. São Paulo: Saraiva, 2007.

DONIZETTI, Leila. Filiação Socioafetiva e Direito à Identidade Genética. Rio de Janeiro: Lumen Juris, 2007. 
FLACELIÈRE, Robert. A vida cotidiana dos gregos no século de Péricles: Livros do Brasil. Tradução: Virginia Motta, 1985.

FERNANDES, Silvia da Cunha. As técnicas de reprodução humana assistida e a necessidade de sua regulamentação jurídica. São Paulo: Renovar, 2005.

FUJITA, Jorge Shiguemitsu. Filiação. São Paulo: Atlas, 2009.

HOUAISS, Antônio. SALLES, Vilar e SALLES, Mauro de. Dicionário Houaiss da Língua Portuguesa. 1 ed. Rio de Janeiro: Objetiva, 2001.

LÔBO, Paulo Luiz Netto. Entidades familiares constitucionalizadas: para além do numerus clausulus. In: CONGRESSO BRASILEIRO DE DIREITO DE FAMÍLIA, 3., 2003, Belo Horizonte. Anais... Belo Horizonte: Del Rey, 2003.

NOVELINO, Marcelo. Direito Constitucional. 3. ed. São Paulo: Método, 2009.

PERTTERLE, Selma Rodrigues. O Direito fundamental à identidade genética na Constituição brasileira. Porto Alegre: Livraria do Advogado, 2007.

POSTER, Mark. Teoria Crítica da Família. Rio de Janeiro: Zahar, 1979.

SIDOU, J. M. Othon. Dicionário Jurídico: Academia Brasileira de Letras Jurídicas. 9 ed. Rio de Janeiro: Forense Universitária, 2004.

VENOSA, Sílvio de Salvo. Direito Civil, Direito de Família. 6. ed. São Paulo: Atlas, 2006.

CHAMOU, Ebert. Instituições de Direito Romano. 5 ed. Rio de Janeiro: Forense, 1968.

CURY Munir. GARRIDO DE PAULA, Paulo Afonso; et. al. Estatuto da Criança e do Adolescente Anotado. $3^{\mathrm{a}}$ ed. São Paulo: Revista dos Tribunais, 2002. 
GOGLIANO, Daisy. Direitos Privados da Personalidade. Dissertação de Mestrado apresentada no Curso de Pós-Graduação stricto sensu da Faculdade de Direito da Universidade de São Paulo, São Paulo, 1982.

LÔBO, Paulo Luiz Netto. Direito ao estado de filiação e direito à origem genética: uma distinção necessária. Revista CEJ, Brasília, n. 27, out./dez. 2004.

BROWN, Margaret R. Drama latente acirrada polêmica sobre "bebês de proveta". Disponível em: <http://www.acidigital.com/vida/probeta.htm>. Acesso em 07 de maio de 2013. LÔBO, Paulo Luiz Netto. A repersonalização das relações de família. Disponível em: $<$ http://jus2.uol.com.br/doutrina/texto.asp?id=5201>. Acesso em 22 de abril de 2018. 


\title{
VARIAÇÕES SOBRE O MESMO TEMA: O CONTRATO EM CONTEXTO POLÍTICO, SOCIAL E ECONÔMICO
}

\author{
Laís Machado Lucas \\ PUCRS/UNISINOS
}

\begin{abstract}
Resumo
O contrato, instrumento que concretiza a autonomia privada, não se submete somente a esta no que tange a sua formatação e interpretação. Ele está constantemente submetido a variações do meio que é celebrado, sofrendo interferências políticas, sociais e econômicas. Neste sentido, questiona-se se o contrato não está sujeito a uma alteração de sua gênese a ponto de servir a interesses diversos daqueles pretendidos pela vontade das partes que o firmaram.
\end{abstract}

Palavras-Chaves: contrato, interpretação, liberalismo, socialidade, economia.

\begin{abstract}
Resumen/Résumé
The contract, an instrument that concretizes the private autonomy, is not only submitted to it in terms of its formatting and interpretation. It is constantly subjected to variations of the medium that is celebrated, suffering political, social and economic interferences. In this sense, it is questioned if the contract is not subject to a change of its genesis to the point of serving interests different from those intended by the will of the parties that signed it.
\end{abstract}

Keywords/Palabras-claves/Mots-clés: contract, interpretation, liberalism, sociality, economy.

\section{Introdução}

Contrato, instituto jurídico comumente definido como um acordo de vontades. Tão antigo, quanto utilizado; talvez a ferramenta jurídica mais usada pelos operadores do direito e pelos destinatários da lei. Esse seu caráter utilitário, contudo, não lhe retira a complexidade; muito pelo contrário, por ser um instituto tão próximo dos cidadãos não juristas e tão envolvido 
com o cotidiano destes, ele absorve constantemente as alterações sociais e econômicas, para melhor se adequar às necessidades dos seus usuários.

A estreita ligação existente entre contrato e economia e, a relação permeável que se forma entre este com o ambiente sócio-político em que estão inseridos, resultam em uma constante evolução da disciplina contratual. Afinal, o contrato se revela, primordialmente, como instrumento para a circulação das riquezas produzidas pela sociedade. Em sendo assim, imediatamente percebe-se que o instituto ultrapassa o simples conceito de "acordo de vontades", possuindo vieses mais peculiares que merecem atenção dos juristas.

Para uma exata compreensão da problemática, a atenção referida não deve concentrarse somente no contrato, instrumento jurídico, em si, mas sim, em todos os elementos que o envolvem, que podem ser resumidamente descritos como econômicos, políticos e sociais. No entanto, percebe-se que a observância demasiada desses elementos externos aos contornos jurídicos, podem desnaturar o instituto, a sua gênese e causar alterações significativas na sua interpretação.

Pretende-se com essa pesquisa, através da análise bibliográfica da evolução do contrato e das suas formas de interpretação verificar se o mesmo não está passando por um desvirtuamento da sua gênese, qual seja, ser a expressão máxima da autonomia privada dos indivíduos.

\section{O Contrato}

Mesmo sem perceber, todos os dias qualquer indivíduo firma pelo menos um contrato. A maioria desses contratos não está revestida de formalidades, a ponto de se considerar as atitudes mais corriqueiras, um instituto jurídico estudado há centenas de anos: ir à padaria para comprar pães, ingressar em um ônibus para ir ao trabalho, almoçar ou jantar em um restaurante, fazer uma consulta médica, locar um filme na locadora, fazer um download de uma música de um site da internet, utilizar o valor do "cheque especial", matricular-se em um curso de idiomas, são só alguns exemplos de operações que se traduzem juridicamente em contratos de compra e venda, transporte, financiamento (mútuo) ou prestação de serviços. Normalmente, a maioria dos cidadãos somente vai considerar que está contratando quando firmar pactos que estejam revestidos de formalidades por exigência legal, como, por exemplo, a compra ou venda de um imóvel, ou quando os valores envolvidos forem significantes (compra ou venda de um automóvel, contratação de uma empreiteira para a reforma da casa, financiamento para aquisição de bens, entre outros). 
Agregam-se a essa contratações cotidianas, revestidas, no mais das vezes, de uma menor importância para o tráfego negocial e dispendiosas de pequenas somas financeiras, aquelas contratações realizadas por empresas, para o desenvolvimento de suas atividades.

Essas ponderações foram feitas inicialmente para que se possa refletir a importância do contrato na vida de todos, independentemente da classe social a que pertença, ou ao status que ocupe (empresário ou não empresário) já que a existência humana em uma sociedade com viés capitalista torna-se praticamente inviável sem a formação constante de contratos. Isso porque, todos os indivíduos, aqui consideradas pessoas físicas e jurídicas, estão inseridos em um contexto econômico que compele constantemente a efetuar "trocas" ou a "circular riquezas", que podem ser traduzidas pela expressão “contratação". Neste contexto, vale lembrar o ensinamento de Roppo (ROPPO, 2009), "que o contrato-conceito jurídico e o direito dos contratos são instrumentais da operação econômica ${ }^{1}$, constituem a sua veste formal [...]”.

Também se deve ressaltar que alguns desses contratos firmados, além de permitirem a coexistência econômico-social, são indispensáveis para o indivíduo autonomamente falando, por guardarem relação com as necessidades mais básicas, como por exemplo, contratos de planos de saúde, contratos de prestação de serviços essenciais de água e luz, contratos de locação residencial, entre tantos outros, que se prestam a resguardar direitos subjetivos da pessoa, para que ela possa viver com o mínimo de dignidade (NEGREIROS, 2006). Importa referir, neste ínterim, a classificação proposta por Ruy Rosado de Aguiar Junior que distingue os contratos existenciais (como aqueles $\mathrm{j}$ [a referidos) e os contratos de lucro, aqueles celebrados por empresas no exercício da sua atividade econômica (AGUIAR JUNIOR, 2011).

Por estar intimamente ligado com a economia e suas operações, e fazer parte do contexto social, é que o instituto do contrato tem uma feição cambiante, alterando-se conforme as necessidades do mercado e mudanças político-sociais. Nas palavras de Cláudia Lima Marques, "o contrato, por assim dizer, nasceu da realidade social"(MARQUES, 2005). Assim, o contrato concebido na Antiguidade e na Idade Média, tendo um cenário econômico rudimentar, baseado em mão de obra escrava e escambo, e uma estrutura social permeada pelo absolutismo, não é o mesmo contrato pós Revolução Industrial, quando ocorreu um substancial incremento qualitativo e quantitativo das operações econômicas e a mudança do regime social para ascender a burguesia (ROPPO, 2009).

\footnotetext{
${ }^{1}$ Vale lembrar o conceito de Roppo sobre “operações econômicas": “[...] pode dizer-se que existe operação econômica - e portanto possível matéria de contrato - onde existe circulação da riqueza, actual ou potencial transferência de riqueza de um sujeito para outro (naturalmente, falando de "riqueza" não nos referimos só ao dinheiro e aos outros bens materiais, mas consideramos todas as "utilidades" susceptíveis de avaliação econômica, ainda que não sejam “coisas” em sentido próprio [...])”.(ROPPO, 2009)
} 
No período do Direito Romano, o contrato (contractum), juntamente com o pacto (pactum) eram espécies do gênero convenção (conventio), que se distinguiam por aquele (o contrato) ter uma denominação especial que o exteriorizava (por exemplo, comodato, mútuo e compra e venda) e uma sanção, para o caso de descumprimento, que se revelava através de uma “ação". Além disso, os contratos para os romanos obrigatoriamente deviam gerar obrigações entre as partes. Já os pactos não possuíam nenhuma forma de exteriorização determinada ou distintiva, tampouco invocariam uma "ação" para fazer valer os termos ali ajustados (BESSONE, 1997).

Um traço marcante do contrato no Direito Romano era que a sanção, ou a ação pelo descumprimento do ajuste, tinha um caráter penal, pois o devedor pagava com a sua própria "pessoa" pela dívida assumida, e não com o seu patrimônio. Nas palavras de Miguel Maria de Serpa Lopes (SERPA LOPES, 1996), o contrato nesta época significava "o ato por meio do qual o credor atraia a si o devedor, submetendo-o ao seu jugo, como refém, garantia do adimplemento do débito assumido".

Com a evolução do instituto, houve a tendência de eliminar-se a distinção entre pacto e contrato. No direito justinianeu esta idéia parece clara, mas surge outra separação, para considerar o contrato somente como meio capaz de "produzir" obrigações e inapto a modificálas ou extingui-las. Assim, criou-se uma celeuma que, na lição de Darcy Bessone (BESSONE, 1997), girava em torno do mesmo eixo: ora, se para contratar e, consequentemente, produzir efeitos jurídicos, é necessária a comunhão de vontades, por que para distratar, onde também há a vontade como guia, não se poderia dizer que também está se contratando para finalizar o acordo antes firmado? Esta discussão foi praticamente ignorada pela doutrina francesa, que resultou na redação do artigo 1.101, do Code de 1804, que foi explícito na definição de contrato como um ato destinado a produzir efeitos: "Le contrat est une convention par laquelle une ou plusieurs personnes s'obligent, envers une ou plusieurs autres, a donner, a faire, ou a ne pas faire quelque chose".

O contrato no ordenamento civil francês teve a peculiaridade de não estar em um livro próprio dentro da codificação que tratasse exclusivamente das suas questões. Ele foi contemplado no livro dedicado aos "diversos modos de aquisição da propriedade", estando segundo Roppo, em posição "não autónoma, mas subordinada, servil”, em relação a este instituto. Essa postura do legislador francês explica-se através da própria revolução da burguesia, que teve como medida primordial a "libertação e mobilização da propriedade fundiária", ou seja, "suprimir todos os privilégios e direitos feudais", remanescentes do antigo regime, que incidiam sobre a terra. No entanto, para que isso acontecesse, era necessário um 
instrumento que efetivasse essa "transferência da riqueza das classes vencidas para a nova classe nascente", de forma segura, com o mínimo de danos, e que ainda se valesse da vontade das partes a fim de evitar expropriações futuras. O contrato torna-se esse instrumento, permeado pelo dogma da vontade, com intuito maior de assegurar a aquisição ou transferência da propriedade pela burguesia (ROPPO, 2009).

O Código Civil Alemão - BGB - de 1896 trouxe a disciplina contratual de forma distinta do sistema francês, na medida em que se utiliza da teoria do negócio jurídico para fundamentar o fenômeno do contrato. Por este modelo, o negócio jurídico seria uma categoria mais geral, onde se englobariam institutos diversos e distintos do direito (por exemplo, direito de família e sucessões), dentre os quais o contrato. Em outras palavras, o contrato seria uma espécie do gênero negócio jurídico. Este, mais abstrato, aquele (contrato) mais concreto. Obviamente, que pela época em que foi concebido, o BGB também estava impregnado de ideais burgueses. Assim, na teoria do negócio jurídico, a vontade das partes foi "elevada a chave da sua definição", assimilando-se o conceito de negócio jurídico como "uma declaração de vontade dirigida a produzir efeitos" (ROPPO 2009). Ainda em contrapartida do ordenamento francês, o código alemão não se ocupou em fazer uma definição de contrato.

No ordenamento italiano verificou-se uma mescla das concepções de contrato francesa e alemã. No Código Civil Italiano de 1865 há uma clara referência ao modelo francês de contrato, enquanto que o código de 1942 revela a influência alemã. Muito embora o negócio jurídico não tenha sido tratado diretamente nesta legislação, a doutrina recepcionou o instituto sendo este tomado como "conceito ordenador e unificador da atividade jurídica dos particulares ao conceito de contrato". Ademais de outras peculiaridades do código de 1942, como o fato de ter sido redigido e entrado em vigor durante o regime fascista, ele promoveu a unificação do direito das obrigações e dos contratos, trazendo para dentro da disciplina civil o direito comercial (ROPPO, 2009). O artigo 1321 do código de 1942, definiu contrato como sendo "Il contratto è l'accordo di due o più parti per costituire, regolare o estinguere tra loro um rapporto giuridico patrimoniale".

No direito brasileiro, percebe-se uma clara semelhança com o direito contratual alemão, tanto no Código Civil de 1916 (Lei 3.071, de 01 de janeiro de 1916), quanto no Código Civil de 2002 (Lei 10.406, de 10 de janeiro de 2002) (FICHTNER, 2006). Nestes dois diplomas normativos há livro específico para tratar do negócio jurídico (denominados de "Fatos Jurídicos"), que antecede os demais institutos regulados pelo código, tais como o direito de família, o direito das sucessões, o direito das coisas e o direito dos contratos. Especificamente quanto ao Código Civil de 2002, percebe-se, também, uma aproximação ao ordenamento civil 
italiano, no que tange a unificação das obrigações civis e comerciais em um mesmo diploma legal. Assim, com a promulgação da Lei 10.406, de 10 de janeiro de 2002, foi revogada a "parte primeira" do Código Comercial brasileiro de 1850 (Lei 556, de 25 de junho de 1850).

Os contratos no atual diploma civilista estão previstos a partir do artigo $421^{2}$, sem que haja uma definição precisa deste instituto, optando o legislador em positivar somente os princípios que devem regê-lo. Aliás, no Código Civil de 1916 também não há uma conceituação de contrato, tendo ficado a cargo da doutrina esta construção.

$\mathrm{Na}$ doutrina não ocorreram muitas discussões ou divergências acerca do conceito de contrato, até porque se tomou como base o conceito de Ato Jurídico, presente no artigo 81 do Código de 1916. De forma simplificada pode-se definir contrato como "o acordo de vontades com a finalidade de produzir efeitos jurídicos", ou, de forma mais completa como "um acordo de vontades, na conformidade da lei, e com a finalidade de adquirir, resguardar, transferir, conservar, modificar ou extinguir direitos" (SILVA, 2004). Em que pese a semelhança dos termos, cumpre destacar a definição dada por Darcy Bessone, por esta se amparar na conceituação trazida pela legislação italiana, em que "o contrato é o acordo de duas ou mais pessoas para, entre si, constituir, regular ou extinguir uma relação jurídica de natureza patrimonial” (BESSONE, 1997).

O conceito de contrato não sofreu grandes variações ao longo da história do instituto, mantendo sempre a ideia de que era o instrumento que traduzia o encontro de duas ou mais vontade para a produção de uma finalidade e/ou efeito. A transformação que se opera no contrato com a evolução (ou não) política, econômica e social diz com os seus valores formativos, modificativos e limitativos, isto é, "contrato" continuará sendo um acordo, que obviamente, deriva da vontade dos contratantes, mas conforme o cenário em que está inserido, a vontade terá uma valoração distinta, será utilizada (ou não) a boa-fé como meio de interpretação dos pactos, estes poderão (ou não) ser limitados pela função social, ou então, revisados (ou não) em nome do equilíbrio contratual. Ou seja, a comunhão de interesses será sempre "contrato", mas os seus contornos dependerão do ambiente onde serão concluídos e executados.

E a afirmação acima se confirma pela história. Nos últimos dois séculos os contratos experimentaram pelo menos dois tipos distintos de "contornos", que foram um espelho do momento político, econômico e social pelos quais passaram as sociedades ocidentais.

\footnotetext{
${ }^{2}$ Art. 421. A liberdade de contratar será exercida em razão e nos limites da função social do contrato.
} 


\subsection{Quem diz contratual, diz justo.}

O pensamento liberal, ou liberalismo, foi um evidente movimento de oposição ao Estado Absolutista, vigente até meados do século XVIII. Podem ser encontradas várias motivações para esta nova ideologia, mas é no progresso econômico da classe burguesa que se encontram os argumentos mais contundentes (WEBER, 2005).

$\mathrm{Na}$ vigência do ancien régime, a nobreza era a grande detentora da propriedade, restando para a sociedade em geral, que era dividida em estamentos, a realização do "trabalho" para a subsistência de todos. Este "trabalho", em um primeiro momento, tinha contornos manufatureiros, ou seja, baseava-se na produção para a sobrevivência, com a troca de excedentes entre a população. A evolução dos meios de produção levou ao progresso comercial e ao mercantilismo, fazendo com que a classe que detinha estes meios de produção ascendesse: é neste momento que a burguesia começa a ganhar seu espaço e a incomodar-se com o Estado Absolutista. Este incômodo, na esteira do pensamento de Marília de Ávila e Silva Sampaio (SAMPAIO, 2006), ocorria porque a classe emergente não mais queria repartir seus ganhos com o setor público. No entanto, o domínio econômico não bastava para que a burguesia se firmasse e modificasse o regime até então vigente. É neste contexto, que surge a teoria de John Locke (LOCKE, 1689), para fomentar e consolidar os ideais burgueses, que alia a propriedade privada (muito desejada pela burguesia) e o direito natural, que era concebido como o direito inerente ao indivíduo, a coisas ou situações indispensáveis a sua sobrevivência.

A teoria de Locke foi perfeita às aspirações burguesas porque ele considerou o direito à propriedade um direito natural, partindo do princípio de que fazem parte desta categoria de direitos a vida, a liberdade e os bens necessários para a conservação de ambos. $\mathrm{O}$ acesso a estes bens seria resultado do trabalho do indivíduo, que por consequência, torna-se o elemento legitimador da propriedade privada pelo burguês. Para chegar a esta conclusão, o grande pensador desenvolveu o seguinte raciocínio, que foi muito bem sintetizado por Marilena Chauí, ao referir que "Deus instituiu, no momento da criação do mundo e do homem, o direito à propriedade privada como fruto legítimo do trabalho. Por isso, de origem divina, ela é um direito natural." (CHAUÍ, 2000)

Tendo o domínio econômico e uma teoria que apoiasse seus ideais, a burguesia estava pronta para iniciar o processo de transformação que viria a consolidar no cenário social, político e econômico os princípios máximos do liberalismo, quais sejam, a liberdade individual e a igualdade formal. A liberdade só poderia ser garantida com a clara separação entre Estado e sociedade, que se materializava com a intervenção mínima daquele sobre esta. Ou seja, Estado 
e sociedade seriam dois "universos distintos, regidos por lógicas próprias e incomunicáveis" (SARMENTO, 2006). A igualdade formal, por sua vez, só seria atingida com a existência de um direito que fosse aplicado de forma igualitária a todos os membros da sociedade, independentemente de situações particulares ou peculiares.

Várias foram os movimentos sociais que tinham como essência a ideologia liberal. Pode se destacar a Revolução Gloriosa, na Inglaterra, em 1688, a Revolução Americana de 1776 (luta pela independência dos Estados Unidos), e o ápice das revoluções, que foi a Revolução Francesa de 1789. A Revolução Francesa é considerada como o marco do liberalismo na Europa, pois foi a partir da sua eclosão, que o Estado Liberal começou a firmarse como modelo político no mundo ocidental. A sua relevância também se assenta em outros dois pontos: primeiro, no seu documento guia, que foi a Declaração dos Direitos do Homem do Cidadão, que consagra, no seu preâmbulo, "os direitos naturais, inalienáveis e sagrados do homem"; segundo, na propagação, ainda hoje em voga, dos seus ideais de igualdade, liberdade e fraternidade (SARMENTO, 2006).

Assim, o liberalismo se firma como uma postura de defesa do indivíduo, desafiando atos arbitrários do governo (até então absolutista), que persegue a liberdade (principalmente aquela que diz respeito à iniciativa econômica) e a igualdade (formal) entre todos os cidadãos. O lema deste período passa a ser a célebre frase atribuída a Voltaire: "Discordo de tudo o que dizeis, mas darei a vida para que tenhais o direito de dizê-lo".

O capitalismo é içado como modelo econômico do Estado Liberal, tomando-se a obra de Adam Smith (SMITH, 1986) como referência teórica. Para este autor o Estado deve ser "mínimo", ocupando-se basicamente de três tarefas: 1) de promover a soberania nacional, defendendo a sociedade da violência e invasão externas; 2) promover a proteção interna dos membros da sociedade contra a opressão e injustiças de outros membros, e, 3) erigir e sustentar as instituições e obras públicas que sejam vantajosas para a sociedade, mas que não sejam atrativas para os capitalistas, seja pelo lucro, risco ou incapacidade dos mesmos de mantê-los funcionando. Como síntese do pensamento econômico liberal tem-se a expressão cunhada pelo mesmo Adam Smith, "a mão invisível do mercado", pela qual se entende que o mercado (economia) por si só, é capaz de se autorregular, sendo dispensável e desaconselhável qualquer intervencionismo estatal.

Como bem expôs o ilustre doutrinador Paulo Bonavides "na doutrina do liberalismo, o Estado foi sempre o fantasma que atemorizou o indivíduo" (BONAVIDES, 2009). Diante deste temor, nada mais coerente que a sociedade almejasse a sua separação do Estado, também de forma política, como já referido, e para isso buscasse na "separação dos poderes de 
Montesquieu (executivo, legislativo e judiciário)" o seu embasamento teórico. O acolhimento desta teoria se justifica porque a burguesia queria o afastamento do poder do Estado, mas não queria que este recaísse sobre o povo (que levaria à democracia). "Montesquieu advogava o princípio liberal, abarcava a solução intermediária, relativista, que, de um lado, afastava o despotismo do rei e, de outro, não entregava o poder ao povo" (BONAVIDES, 2009). Para efetivar o poder político nas mãos dos burgueses foi instituído o voto censitário, de forma que só seriam eleitores aqueles que tivessem renda e/ou propriedade. Dessa forma, conforme ensina Cezar Saldanha Souza Junior (SOUZA JUNIOR, 1984), afastava-se "do sufrágio aquelas camadas sociais que, não tendo nada a perder, pudessem, de um modo ou de outro, desviar o comportamento do Estado dos rígidos padrões do figurino liberal”.

Na ciência jurídica, o liberalismo manteve seus pilares de separação entre Estado e Sociedade, abrindo uma fenda intransponível entre Direito Público e Direito Privado, tendo este último maior hegemonia, já que representava a expressão jurídica da autonomia da vontade da burguesia (MARTÍNEZ, 1995). Ao Direito Público cabia regular as disciplinas atinentes à estruturação do Estado, enquanto ao Direito Privado cumpria a função de regular as matérias relativas às relações particulares. Então, tinham-se dois documentos estanques e incomunicáveis entre si: a constituição que trataria do Direito Público, com normas destinadas ao Estado e o Código Civil, que contemplaria as matérias dos particulares.

Ao Código Civil, que bem poderia ser chamado de "constituição da sociedade civil", foram delegadas as normas que regeriam os particulares entre si, "supostamente imutáveis, porque fundadas nos postulados do racionalismo jusnaturalista, que tinham seu centro gravitacional na ideia de autonomia privada" (SARMENTO, 2006).

Gustavo Tepedino (TEPEDINO, 2000) descreve esta vinculação estrita entre Código Civil e relações de direito privado, como um "fetiche", assim como também classifica de "fetichismo" a pretensão do legislador liberal em considerar que o direito codificado esgota o fenômeno jurídico. O referido doutrinador ainda destaca que o legislador liberal tinha a presunção, ou em suas próprias palavras, a "onipotência" de tentar prever e, por consequência, codificar "todas as condutas do fenômeno social que pudessem ser relevantes para o direito".

Tal tentativa do liberalismo, de tudo prever, explica-se pelo seu modelo econômico, já que o capitalismo precisava, para o seu desenvolvimento, de estabilidade e segurança jurídica e isto é mais fácil de alcançar com um sistema racional e que valha para todos da mesma forma (igualdade formal) (MARTÍNEZ, 1995). Daniel Sarmento leciona sobre este tema que "o papel do direito privado era o de garantir as regras do jogo, estabilizando as relações econômicas, e 
ele o fazia assentando-se sobre dois pilares: propriedade e contrato, ambos vistos como expressões necessárias da autonomia do indivíduo" (SARMENTO, 2006).

O contrato foi um dos institutos jurídicos mais importantes do Estado Liberal. Isso porque, o desenvolvimento do tráfego mercantil e a possibilidade da burguesia se tornar proprietária, fomentaram a criação de um instrumento que pudesse garantir as transações e comprometer as partes. Além de ser uma forma de alcançar a segurança jurídica, o contrato ainda se revela, neste período, como a expressão máxima da liberdade do homem, eis que surge como meio para o exercício da autodeterminação. Para Roppo, a liberdade de contratar do período liberal, é uma clara evolução em relação a sociedade antiga, que aprisionava o indivíduo "numa rede de incapacidades legais". Esta liberdade devolveu ao sujeito o poder de se autodeterminar e estava ancorada na igualdade formal, que buscava tornar todos iguais perante a lei. Nas palavras do doutrinador, a liberdade "significa, numa palavra, passagem a uma forma superior de sociedade"(ROPPO, 2009).

A autodeterminação conferida aos particulares pode ser traduzida, como já referido, pela "autonomia privada" que se destaca como fundamento dos três principais princípios do "contrato clássico": a liberdade de contratar (as partes são livres para contratar, com quem, como, onde e quando quiserem); a obrigatoriedade dos efeitos contratuais, que pode ser simplificada com a máxima "o contrato faz lei entre as partes", ou na expressão latina pacta sunt servanda; e a relatividade dos efeitos contratuais (res inter alios acta tertio neque nocet neque prodest), que vinculava ao pacto somente as partes que dele foram signatárias, não beneficiando nem prejudicando terceiros (JUNQUEIRA DE AZEVEDO, 2004).

Em sendo a autonomia privada a "força motriz" da contratação liberal, cabia ao direito somente garantir que a manifestação de vontade que deu origem ao pacto fosse hígida. Ou seja, a proteção jurídica cingia-se ao momento de formação do contrato para assegurar que a vontade que estava sendo declarada para a formação deste correspondesse à vontade interna dos sujeitos da relação contratual. Assim, como bem exposto por Cláudia Lima Marques (MARQUES, 2005), a doutrina, jurisprudência e a legislação da época concentravam seus esforços para garantir a realização da vontade na sua íntegra, pois "somente a vontade livre e real, isenta de vícios ou defeitos, pode dar origem a um contrato válido, fonte de obrigações e de direitos".

A liberdade de contratar posiciona-se como o mais básico e fundamental dos princípios do direito contratual clássico, pois é através da união da liberdade e da vontade do sujeito que surgirá ou não o contrato. Assim, este princípio firma-se como a opção do indivíduo de contratar ou não, escolher o seu parceiro contratual, as cláusulas constantes do pacto, podendo manifestar neste todas as suas vontades, que seriam devidamente protegidas pelo direito, desde que não 
estivessem eivadas de vícios (MARQUES, 2005). Como bem explica Enzo Roppo, neste período não eram impostos limites positivos ao contrato, que determinassem condutas a serem tomadas pelos contratantes; somente se impunham limites negativos que informavam as fronteiras até onde o pacto poderia ir. Explica Roppo, que "não se admitia, por princípio, que a liberdade contratual fosse submetida a vínculos positivos, a prescrições tais que impusessem aos sujeitos, contra a sua vontade, a estipulação de um certo contrato, ou a estipulação com um sujeito determinado, ou por um certo preço ou em certas condições: os poderes públicos legislador e tribunais - deviam abster-se de interferir, a que título fosse, na livre escolha dos contraentes privados." (ROPPO, 2009)

Também intimamente ligado à liberdade de contratar e a autonomia da vontade, está o segundo princípio do contrato liberal, que é a obrigatoriedade do pacto firmado. Por este princípio entende-se que, se a vontade foi manifestada higidamente, usando o indivíduo a sua plena liberdade, os contratos devem ser cumpridos a qualquer custo, não cabendo ao judiciário nenhum tipo de intervenção para modificar o pacto firmado, nem às partes o direito de desistência (MARQUES, 2005; TIMM, 2008). Isso porque, utilizando-se dos ensinamentos de Serpa Lopes (SERPA LOPES, 1996) "todo o edifício do contrato assenta na vontade individual, que é a razão se ser de uma força obrigatória", acreditando-se que se o ajuste não fosse bom para qualquer das partes, esta não se vincularia ao contrato.

Esta obrigatoriedade muito convinha ao Estado Liberal, principalmente ao seu modelo econômico, pois propiciava um ambiente de estabilidade e uma certeza, de que, mesmo os contratos que no seu curso se tornassem "injustos" para uma das partes, deveriam ser estritamente cumpridos, cabendo ao Poder Judiciário resguardar o adimplemento ${ }^{3}$. Conforme Serpa Lopes (SERPA LOPES, 1996), o juiz nada podia fazer diante da vontade do sujeito, considerada "soberana"; "a sua função limita-se a assegurar-lhe o respeito, na proporção da inexistência de qualquer vício de consentimento ou de qualquer vulneração às regras de ordem pública". Todo o embasamento deste princípio foi construído através da célebre frase atribuída a Fouillée, "quit dit contractuel dit juste" (quem diz contratual, diz justo) ou, em outras palavras, a justiça contratual estaria garantida pelo consenso das partes.

\footnotetext{
${ }^{3}$ Sobre esta temática é elucidativa a lição de Enzo Roppo: "um principio que (pacta sunt servanda), além da indiscutível substância ética, apresenta também um relevante significado econômico: o respeito rigoroso pelos compromissos assumidos é, de facto, condição para que as trocas e as outras operações de circulação da riqueza se desenvolvam de modo correcto e eficiente segundo a lógica que lhes é própria, para que se não frustrem as previsões e cálculos dos operadores [...]; condição necessária, assim, para a realização do proveito individual de cada operador e igualmente para o funcionamento do sistema no seu conjunto". (ROPPO, 2009).
} 
O terceiro princípio contratual, o da relatividade dos efeitos do pacto, diz que o contrato somente gera direitos e obrigações às partes que o firmaram. Mais uma vez, encontrase a autonomia da vontade como cerne do princípio, uma vez que, se o contrato é "lei" entre as partes, nada mais coerente que a sua obrigatoriedade somente atinja aqueles sujeitos que dele foram signatários, ou seja, aqueles que livremente manifestaram sua vontade com o intuito de contratar. Assim, os limites dos efeitos do contrato estão diretamente vinculados as manifestações de vontades que foram apostas, acreditando-se que o pacto firmado entre duas partes em nada poderia afetar a esfera jurídica de um terceiro, alheio à relação contratual (FACCHINI, 2007).

Em síntese, a liberdade de contratar e a igualdade formal entre as partes eram os pilares do modelo liberal de contrato. É certo que esta liberdade tinha um cunho revolucionário, pois através dela se rompiam as amarras do Estado Absolutista. Ocorre que, a igualdade não atingia a todos, pois, como já referido, o modelo liberal, como um todo, foi concebido para satisfazer os interesses da classe burguesa, classe esta, detentora do capital. O problema surge, referindose especialmente aos contratos, quando as partes contratantes não gozavam da mesma igualdade, o que levava a um pacto desproporcional, seja por questões econômicas ou intelectuais. Isso fazia com que a justiça contratual se abalasse pela desproporção entre prestação e contraprestação.

Os indícios mais fortes da desigualdade foram sentidos nos contratos de trabalho, onde o direito civil desconsiderava os fatos reais, presumindo patrão e empregado partes iguais na relação. Diante desta situação insustentável, surge o direito do trabalho, que vai proteger a parte mais fraca e inaugurar um novo tipo de normatização: tratamento igual aos iguais, e desigual aos desiguais.

No entanto, como pondera Daniel Sarmento (SARMENTO, 2006), a efetiva mudança de pensamento - que constatou que o modelo político, econômico e jurídico calcado no liberalismo não mais atendia ao momento social que se vivia — se deu com a quebra da Bolsa de Nova York, em 1929, quando o Estado teve de intervir na economia dos Estados Unidos para reestruturá-la. O então Presidente Roosevelt, valeu-se das ideias de Keynes, economista que defendia a interferência do Estado na economia, para lançar o New Deal, superar a crise sem precedentes que se abatera sobre a economia norte-americana, e consolidar o poder da maior potencia mundial. 
2.2 O primado do "ser" sobre o "ter".

A busca por melhorias sociais, que levou ao que se denomina "Estado Social" (BONAVIDES, 2006), surge quando os ideais do liberalismo não mais se adequavam a realidade vigente. O problema da questão social, que se revelava através da crescente pobreza e de "injustiças sociais", decorrentes do êxodo rural, da concentração populacional nas cidades e da revolução industrial (TIMM, 2008), levou ao aumento da complexidade da sociedade moderna e das demandas por ela impostas, a partir do final do século XIX e início do século XX. O modelo de Estado Liberal, até então absenteísta, formal e individualista, começa a transformar-se em um Estado material de Direito, voltando-se para as necessidades sociais e alterando o paradigma liberal da proteção do indivíduo para o paradigma social de defesa da coletividade.

Deve-se destacar que o Estado Social não se confunde com o Estado Socialista, pois não houve a ruptura com modelo econômico do capitalismo (TIMM, 2008). O intuito desta nova forma de organização política era promover o Bem-Estar Social (Welfare State), garantindo a toda a população condições mínimas de vida, tais como saúde, previdência, educação, entre outras (SARMENTO, 2006). Neste contexto, o individualismo característico do Estado Liberal dá lugar a uma postura comprometida com a socialidade, marca do Estado Social, fazendo ressurgir o conceito de solidariedade.

A solidariedade não era elemento estranho, já que há muito ocupava o pensamento dos filósofos e permeava os dogmas da religião (FARIAS, 1998). A "solidariedade dos antigos", valendo-se da expressão de Peces-Barba, possuía um forte caráter religioso, ancorada na epístola de São Pedro "amai-vos intensamente uns aos outros [...]". Esta se expressa, principalmente, através das idéias de Aristóteles, Cícero e Sêneca, para quem o ideal de solidariedade perpassa os sentimentos de amizade (ou amizade cívica, como diria Aristóteles), fraternidade, amor e união entre os homens, ajuda mútua, irmandade; é o reconhecimento do outro como tal, frente a ideia egoísta da utilidade exclusiva e excludente. Para a religião, com base na doutrina de São Tomás de Aquino, a solidariedade é traduzida como caridade e piedade, sentimentos que se materializam através da vida igual em comunidade, da ausência de propriedade privada, e com a crítica aos ricos e a defesa dos pobres (MARTÍNEZ, 1995).

Com o Renascimento, o conceito de solidariedade sofre alterações, já que busca a desvinculação desta da religião. A laicização do conceito lhe traz novos elementos identificadores, tais como a) a igualdade entre todos; b) a negação da coisificação das pessoas; c) a defesa e promoção dos menos favorecidos patrimonialmente; d) a razão como origem da 
solidariedade; e e) a solidariedade como fundamento para o combate da miséria (MARTÍNEZ, 1995). Diante dessas novas características a solidariedade, agora tida como solidariedade dos “modernos", será o fundamento teórico para promover as mudanças tão almejadas pela população, que servirão de sustentáculo para a formação do Estado Social.

Um dos suportes da solidariedade dos modernos foi a doutrina de Émile Durkheim, publicada em seu livro "A Divisão do Trabalho Social”. Para o sociólogo francês, a solidariedade pode ser dividida em solidariedade mecânica e solidariedade orgânica. A solidariedade mecânica é típica da fase primitiva da organização social (como em sociedades pré-agrícolas) e se origina das semelhanças psíquicas e sociais entre os membros individuais. Todos os membros da sociedade desempenham tarefas idênticas ou parecidas. A ligação entre os componentes da sociedade advém da dependência de todos no sistema social geral, e não em alguns indivíduos. O progresso da divisão do trabalho faz com que a solidariedade mecânica se transforme em orgânica. Esta não se baseia na semelhança entre os componentes, como a mecânica, mas sim na junção das partes diversificadas. $O$ encontro de interesses complementares desenvolve um novo laço social. Como nos órgãos de um ser vivo, os indivíduos exercem funções específicas e contam com o bom desempenho dos demais indivíduos para que o sistema continue a funcionar bem. Se um órgão apresenta problemas, o seu mau funcionamento prejudica os demais. A solidariedade orgânica aporta uma maior autonomia e uma consciência individual mais livre, ao mesmo tempo em que a interdependência entre os seres é o seu pilar de sustentação (DURKHEIM, 1977).

Toda a construção teórica da solidariedade dos modernos tinha o intuito de consolidar a ideia de que o ser humano é um ser essencialmente social e suas relações ocorrem em sociedade, eis que um indivíduo só existe na medida em que se relaciona com os demais. Assim, tais relações sociais são constitutivas de sua existência e fazem dele um ser único, em razão de sua relação com os outros indivíduos (alteridade), com o mundo e com os objetos que o cercam (ELIAS, 2001). Logo, com o progresso da sociedade como um todo (na visão de Durkheim) não há como manter-se a ideia do ser como átomo isolado, que vive para cultuar o seu ego e promover exclusivamente os seus interesses (premissas do liberalismo).

Com isso, verifica-se que o princípio da solidariedade trata-se de um fato social total, como leciona Marcel Mauss (MAUSS, 1974), já que se está diante de uma manifestação social complexa, que agrega dimensões simbólicas vinculadas a aspectos históricos, psicológicos e sociológicos que, de maneira interligada, transmitem significados e perspectivas subjetivas. Neste sentido, o homem amarrado a complexas teias de relações que ele mesmo tece, forma múltiplas estruturas conceituais complexas, organizadas de maneira sobreposta, irregulares ou 
implícitas, cria a cultura em que está inserido como um sistema entrelaçado de signos interpretáveis, que representam um contexto determinado e só pode ser entendido enquanto tal (GEERTZ, 1986).

Assumir a solidariedade como substrato das relações sociais não significa que o indivíduo será ignorado na sua condição de ser único e merecedor da tutela da sua dignidade, tendo de renunciar a sua individualidade em prol da coletividade; significa, sim, que todos os indivíduos devem obrar para um fim comum e fazer do espaço social um lugar de cooperação, diálogo e igualdade. O ambiente social não deve ser um espaço de concorrência entre seus atores, mas sim, um espaço onde haja reconhecimento de cada um pelos outros como pares (SARMENTO, 2006).

Assim, a solidariedade buscada como fundamento do Estado Social é aquela que difere da piedade ou da caridade, pois como bem questiona Maria Celina Bodin de Moraes (MORAES, 2006), “como seria possível obrigar alguém a ser solidário? Não seria o mesmo que querer exigir o sentimento de fraternidade entre as pessoas?" O que se quer da solidariedade que lastreia o Estado Social é que os seres que compõe a sociedade sejam vistos e atendidos nos seus anseios e tratados de forma igual ou desigual na medida de suas características, a fim de se conquistar a justiça social. É a garantia de uma existência digna, comum a todos, em uma sociedade que se desenvolva como livre, justa, sem excluídos ou marginalizados (MORAES, 2006).

A perseguição dos novos ideais do Estado Social é tarefa que envolveu tanto o Estado quanto os indivíduos que o compõe. Assim, a solidariedade pode ser considerada levando-se em conta duas relações distintas onde será aplicada. A primeira relação, entre Estado e indivíduos, revela a solidariedade vertical, identificada com os deveres estatais, dado que este, constituindo-se um Estado Social, tem por obrigação minimizar as desigualdades existentes, através dos órgãos públicos, de forma a dar maior efetividade aos direitos de todos os membros da comunidade. A verticalidade da relação chama o Estado Social a cumprir as suas duas tarefas básicas, quais sejam, promover o bem comum e garantir a justiça social. A segunda relação, entre os particulares, caracteriza a solidariedade horizontal, esta não mais como um dever do Estado, mas obrigação entre todos os integrantes da sociedade, uns para com os outros (NABAIS, 2005). A solidariedade horizontal se justifica pela lição de Pietro Perlingieri, ao afirmar que "a pessoa é inseparável da solidariedade: ter cuidado com o outro faz parte do conceito de pessoa" (PERLINGIERI, 2008).

Através dessas premissas, uma nova forma de comportamento e pensamento vingava dentro da sociedade. Aos poucos a igualdade formal foi sendo substituída pela material e a 
liberdade irrestrita dos particulares foi limitada naqueles pontos que ofendiam a coletividade. Frise-se que o maior intento do Estado Social era a promoção do bem-estar da sociedade e não somente de alguns mais favorecidos economicamente (SARMENTO, 2006); o intuito era promover um maior assistencialismo aos necessitados, sem romper com o capitalismo do Estado Liberal. Os primeiros efeitos práticos desta nova forma de pensar a sociedade foi o processo de generalização dos direitos humanos, o fim do voto censitário, a permissão para o direito de associação e também para que os representantes da classe trabalhadora pudessem ocupar cargos políticos (MARTÍNEZ, 1995).

Neste contexto, o direito teve um papel de suma importância. Como bem explica Daniel Sarmento, o direito não poderia impor o espírito altruísta nos membros da sociedade, ditando seus "sentimentos". No entanto, poderia criar obrigações jurídicas que vinculassem os agentes, direcionando seus comportamentos para o solidarismo (SARMENTO, 2006).

A mais importante das mudanças ocorridas no direito, na transição de Estado Liberal para Estado Social, foi a superação (ou a tentativa de minoração) da dicotomia Direito Público versus Direito Privado. A maior intervenção do Estado na sociedade fez com este ampliasse sua atuação também na ciência jurídica, ocupando-se de assuntos antes destinados ao direito dos particulares, ou seja, ao Direito Privado. Assim, o Direito Público, que era um direito de matérias relativas à estruturação do Estado, passa a se ocupar de disciplinas atinentes à sociedade e suas relações entre indivíduos, fazendo ingerências no Direito Privado.

Em termos mais precisos, pode-se dizer que as Constituições da época (SARMENTO, 2006), que eram tidas como o documento símbolo do Direito Público, passaram a contemplar matérias que anteriormente estariam previstas nos Códigos Civis, o grande representante do Direito Privado. Como leciona Paulo Bonavides (BONAVIDES, 2006), alguns direitos sociais, como relações de trabalho, educação, previdência, cultura, saúde, que eram estranhos ao Direito Constitucional clássico, começam a integrar os textos das constituições dos Estados Sociais.

Além de integrar os direitos sociais aos seus textos, as constituições do Estado Social buscaram restabelecer a igualdade material, impor o princípio da legalidade ao Poder Executivo, o controle de constitucionalidade das leis ao Poder Legislativo e, no que tange aos particulares, limitar a autonomia da vontade. Para atingir todos estes intentos, a liberdade econômica foi restringida (mas não eliminada, pois não houve ruptura com o capitalismo) e se elevou a status de princípio constitucional a solidariedade social e a dignidade da pessoa humana. Nas precisas palavras de Facchini (FACCHINI, 2007), tem-se que com a nova ordem constitucional, "abandona-se a ética do individualismo pela ética da solidariedade; relativizase a tutela da autonomia da vontade e se acentua a proteção da dignidade da pessoa humana". 
O texto constitucional tornou-se a tábua axiológica do ordenamento jurídico do Estado Social, fortalecendo-se como verdadeira Lei Fundamental dos Estados. Isso leva com que a predominância dos Códigos Civis nas relações privadas seja enfraquecida, eis que muitas das matérias que antes lhes eram competentes agora estavam previstas nas constituições. Assim, fala-se no "esvaziamento" do conteúdo dos Códigos Civis e, consequentemente, na era da descodificação.

No entanto, o texto constitucional sozinho não se demonstrava suficiente para cuidar de toda a complexidade social que se instaurava. A nova realidade jurídico-social, que buscava a igualdade material, não via mais o homem como o mesmo indivíduo em todas as relações que travava. Houve a necessidade de considerar a mesma pessoa de forma distinta, conforme a posição momentaneamente exercida: locador ou locatário, em um contrato de locação; pai, mãe ou filho nas relações familiares; consumidor ou fornecedor, nas relações de consumo, etc.

O Código Civil de 2002, mesmo que concebido anteriormente à Constituição, não ficou alheio ao solidarismo jurídico. Basta ver que o referido Código elegeu como seus três princípios fundamentais a eticidade, a socialidade e a operabilidade (REALE, 2002). Neste sentido, a família deixa de ser tão-somente um núcleo econômico e de reprodução e passa a ser um lugar para a afirmação da dignidade da pessoa humana; a atividade da propriedade passa a ser mais valorizada do que a titularidade desta, em respeito à finalidade produtiva que esta deve ter; para a posse também é reconhecida uma função social, com a diminuição dos prazos de usucapião; a empresa, que passou a ser disciplinada pelo Código Civil, também deve atender a uma função social, na medida em que os empresários e administradores devem harmonizar os interesses desta (obtenção de lucros), com os interesses da sociedade onde ela está inserida; a responsabilidade civil passa a admitir a forma "objetiva" onde não interessa a atribuição de culpa, preocupando-se com a reparação do dano sofrido pela vítima (FACCHINI).

Importante transformação também sofre a disciplina contratual, com a expressa disposição de que o contrato deve respeitar os limites da função social, e os contratantes devem primar pela boa-fé e pela probidade.

A disciplina contratual clássica, como visto anteriormente, previa três princípios fundamentais: (1) a liberdade de contratar; (2) a relatividade dos efeitos do contrato; e (3) a obrigatoriedade do pacto, ou o pacta sunt servanda. Estes princípios estavam diretamente ligados a autonomia privada (liberdade de contratar) e a presunção de que todos eram iguais.

No entanto, a complexidade das relações sociais que se estabelecem na nova ordem do Estado Social, aliada a constatação que a igualdade formal não atende a realidade das relações privadas, fez com que o contrato também se desvinculasse da ótica "oitocentista" para se 
adequar aos ideais solidaristas do Welfare State. Assim, o princípio da liberdade terá de promover o princípio da igualdade material, nem que para isso o Estado tenha que intervir para forçar uma "desigualdade que faça o papel de equilibrar a desigualdade inversa que a situação das partes intrinsecamente envolve" (GODOY, 2007).

Assim, surgem novos princípios que aliados aos princípios clássicos moldarão a nova forma de contratar. O contrato passa, então, a refletir os ideais do Estado Social, na medida em que busca promover trocas justas, com equilíbrio entre prestação e contra prestação, permeadas pelos dogmas da boa-fé entre os contratantes e que respeitem a esfera jurídica de terceiros, atendendo a função social. Com isso, se verifica a chamada "hipercomplexidade" dos princípios contratuais, expressão cunhada por Junqueira de Azevedo (JUNQUEIRA DE AZEVEDO, 2004), para designar que aos clássicos princípios se somam outros que refletem o Estado Social; assim, a autonomia da vontade passa a conviver com a boa-fé; a obrigatoriedade do pacto, com o equilíbrio contratual; e a relatividade com a função social do contrato (FACCHINI, 2007).

Percebe-se, assim, que o legislador pátrio influenciou-se pelos os preceitos solidaristas. O Código Civil de 2002, nos artigos 421 e 422, trouxe quatro preceitos essenciais e correlatos à solidariedade: a liberdade de contratar (inerente à condição de contrato); a função social do contrato; a probidade ${ }^{4}$ e a boa-fé objetiva ${ }^{5}$. Além desses artigos, contemplou a justiça contratual, ou equilíbrio econômico do contrato, nos institutos jurídicos da lesão, estado de perigo, imprevisão e onerosidade excessiva, que possibilitam a revisão ou anulação do pacto.

\subsection{A Dimensão Econômica do Contrato}

$\mathrm{Na}$ década de 70 inicia-se um movimento que lança um novo olhar sobre a ciência jurídica, para analisar esta sob uma perspectiva de premissas econômicas. Os trabalhos de Ronald Coase (The Problem of Social Cost), Guido Calabresi (Some Thougts on Risk Distribution and the Law of Torts) e Richard Posner (Economic Analisys of law) foram os precursores do movimento, que se fortalece até hoje.

\footnotetext{
${ }^{4}$ A Professora Judith Martins-Costa (MARTINS-COSTA, 2008), fez uma distinção do princípio da probidade, com intuito claro de demonstrar que não é necessário exaurir todas as hipóteses de conduta proba e de boa-fé para se compreender o intuito do art. 422, do Código Civil. Para a doutrinadora a probidade do referido diploma legal comporta 04 elementos distintos: "(1) a seriedade no trato das negociações; (2) a veracidade sobre as informações requerida; (3) o segredo em relação a informações confidenciais obtidas no decurso das negociações; e (4) a ausência de uma atitude contraditoriamente desleal, permeada por artimanhas e intuito de ludibrio".

5 Segundo Judith Martins-Costa boa-fé objetiva quer significar um "modelo de conduta social, arquétipo ou standard jurídico, segundo o qual cada pessoa deve ajustar a própria conduta a esse arquétipo, obrando como obraria um homem reto: com honestidade, lealdade, probidade. Por este modelo objetivo de conduta levam-se em consideração os fatores concretos do caso, tais como o status pessoal e cultural dos envolvidos, não se admitindo uma aplicação mecânica do standard, de tipo meramente subjuntivo". (MARTINS-COSTA, 2000).
} 
Logicamente os contratos não ficaram imunes a essa nova perspectiva, ainda mais após a extensa obra de lavra de Fernando Araújo (Teoria Económica do Contrato) em que este sustenta que "a análise econômica do contrato pretende ser complementar da análise jurídica (...) fazendo recair uma especial atenção nos efeitos geradores de riqueza que podem associarse àquele acordo de coordenação de condutas, efeitos que o transformam em veículo de consumação e permuta de utilidades" (ARAÚJO, 2007).

Os tribunais brasileiros não ficaram imunes a esta nova forma de enxergar o contrato. O Superior Tribunal de Justiça, em recente decisão, rompeu com a interpretação usual dos contratos, com base nos princípios presentes no Código Civil. No RESP $1.163 .283^{6}$, de relatoria do Ministro Luis Felipe Salomão, foi utilizada a análise econômica com standard de interpretação da função social do contrato.

Tratava-se de caso envolvendo financiamento imobiliário, onde o Banco recorrente insurgia-se contra o acórdão do Tribunal de Justiça do Rio Grande do Sul que havia afastado a vigência dos artigos 46 e 50 da Lei 10.931/2004 sobre os contratos de financiamento de imóveis. O ponto nevrálgico era justamente o artigo 50, pois este determina que o autor deve indicar na petição inicial nos contratos que tenha por objeto obrigações decorrentes de empréstimo, financiamento ou alienação imobiliários o valor que pretende controverter e depositar os valores que entende incontroversos.

O Ministro inicia seu voto defendendo que a Lei 10.931/2004 foi uma das reações do legislador para o desenvolvimento da economia do país, especialmente para o aumento de

\footnotetext{
${ }^{6}$ RECURSO ESPECIAL. PROCESSUAL CIVIL. CONTRATOS DE FINANCIAMENTO IMOBILIÁRIO. SISTEMA FINANCEIRO DE HABITAÇÃO. LEI N. 10.931/2004. INOVAÇÃO. REQUISITOS PARA PETIÇÃO INICIAL. APLICAÇÃO A TODOS OS CONTRATOS DE FINANCIAMENTO. 1. A análise econômica da função social do contrato, realizada a partir da doutrina da análise econômica do direito, permite reconhecer o papel institucional e social que o direito contratual pode oferecer ao mercado, qual seja a segurança e previsibilidade nas operações econômicas e sociais capazes de proteger as expectativas dos agentes econômicos, por meio de instituições mais sólidas, que reforcem, ao contrário de minar, a estrutura do mercado. 2. Todo contrato de financiamento imobiliário, ainda que pactuado nos moldes do Sistema Financeiro da Habitação, é negócio jurídico de cunho eminentemente patrimonial e, por isso, solo fértil para a aplicação da análise econômica do direito. 3. A Lei n. 10.931/2004, especialmente seu art. 50, inspirou-se na efetividade, celeridade e boa-fé perseguidos pelo processo civil moderno, cujo entendimento é de que todo litígio a ser composto, dentre eles os de cunho econômico, deve apresentar pedido objetivo e apontar precisa e claramente a espécie e o alcance do abuso contratual que fundamenta a ação de revisão do contrato. 4. As regras expressas no art. 50 e seus parágrafos têm a clara intenção de garantir o cumprimento dos contratos de financiamento de imóveis tal como pactuados, gerando segurança para os contratantes. O objetivo maior da norma é garantir que, quando a execução do contrato se tornar controvertida e necessária for a intervenção judicial, a discussão seja eficiente, porque somente o ponto conflitante será discutido e a discussão da controvérsia não impedirá a execução de tudo aquilo com o qual concordam as partes. 5. Aplicam-se aos contratos de financiamento imobiliário do Sistema de Financiamento Habitacional as disposições da Lei n. 10.931/2004, mormente as referentes aos requisitos da petição inicial da ação de revisão de cláusulas contratuais, constantes do art. 50 da Lei n. 10.931/2004. 6. Recurso especial provido. (RESP 1.163.283/RS, Ministro Relator Luis Felipe Salomão, DJe 04/05/2015)
} 
crédito disponível. E, com base nos ensinamentos de Luciano Timm, expõe que o contrato tem um papel institucional e social de oferecer ao mercado segurança e previsibilidade nas relações econômicas. Assim, conclui o Ministro Relator que "dessa forma, a análise econômica do direito aposta no efetivo cumprimento dos contratos de financiamento de imóveis, por exemplo, como pressuposto para o sucesso do sistema como um todo. A satisfação de cada um dos pactos celebrados entre financiadores e financiados, individualmente considerados, é requisito para que o sistema evolua e garanta o beneficiamento de outros tantos sujeitos, de toda coletividade interessada"

O diferencial desta decisão é que o Ministro Relator afastou-se das posturas "apaixonadas" em relação a função do contrato, que neste caso poderia facilmente sucumbir-se a elas por conta do direito a moradia, e fez uma análise técnica e econômica do espírito da legislação debatida e da repercussão deste caso no mercado como um todo.

\section{Conclusão}

Pretendeu-se nesta pesquisa a retomada de conceitos e dados históricos sobre o contrato, com o objetivo de evidenciar as alterações sofridas por esses institutos jurídicos com o passar dos tempos, de acordo com vieses mais políticos, sociais e econômicos, que lhe são imputados em razão da ordem social e da necessidade de atendimento dos agentes econômicos. Essas alterações, como visto, nada mais são de que uma reação do direito a momentos econômicos, sociais e políticos, também cambiantes. E, não poderia ser diferente, afinal, o direito decorre do fato social. A reflexão que se propõe, contudo, é a de uma possível sujeição da autonomia privada, traduzida no cenário contratual pela liberdade de contratar, a interesses coletivos. Independentemente de se considerar isso certo ou errado, considera-se isso preocupante: ora, se a autonomia privada é o espaço dos particulares para se autorregularem e esta autorregulação está sendo "determinada" pelo Estado em seu conteúdo e forma, então talvez se esteja diante da morte de mais um instituto jurídico.

\section{Referências bibliográficas}

AGUIAR JUNIOR, Rui Rosado de. Contratos Relacionais, Existenciais e de Lucro. Revista Trimestral de Direito Civil, vol 45, jan/mar 2011. 
.Projeto de Código Civil - As Obrigações e os Contratos. In: Revista dos

Tribunais, v. 775. São Paulo: Editora Revista dos Tribunais, 2000.

ARAUJO, Fernando. Teoria Economica do Contrato. Coimbra: Almedina, 2007.

BESSONE, Darcy. Do Contrato. Teoria Geral. São Paulo: Saraiva, 1997.

BAUMER, Franklin Le Van. O Pensamento Europeu Moderno: Séculos XVII e XVIII. v. 1. Lisboa: Edições 70, 1977.

BIANCA, Massimo. Diritto Civile - Il Contratto. Milano: Dott Giuffré, 1987

BONAVIDES, Paulo. Do Estado Liberal ao Estado Social. 09 ed. São Paulo: Malheiros, 2009

CHAUÍ, Marilena. Filosofia. São Paulo: Ática, 2000

DURKHEIM, Émile. A Divisão do Trabalho Social. v. I, 02 ed., Lisboa: Editorial Presença, 1977

ELIAS, Norbert. Norbert Elias por ele mesmo. Rio de Janeiro: Zahar, 2001

FACCHINI NETO, Eugênio. Reflexões histórico-evolutivas sobre a constitucionalização do direito privado. $I n$ :

FARIAS, José Fernando de Castro. A origem do Direito de Solidariedade. Rio de Janeiro: Renovar, 1998.

FARINA, Juan M. Contratos Comerciales Modernos. 02 ed. Buenos Aires: Editorial Astrea, 1999.

FICHTNER, Regis, Contrato. In: BARRETTO, Vicente de Paulo (org.). Dicionário de Filosofia do Direito. Rio de Janeiro: Renovar, 2006

GEERTZ, Clifford. A Interpretação das Culturas. Rio de Janeiro: Guanabara, 1986 
GHERSI, Carlos Alberto. Contratos Civiles y Comerciales. 06 ed. Buenos Aires: Editorial Astrea, 2006.

GODOY, Cláudio Luiz Bueno de. Função Social do Contrato. 02 ed. São Paulo: Saraiva, 2007.

HOBSBAWM, Eric J. A Era das Revoluções: Europa 1789-1848. 09 ed. Rio de Janeiro: Paz e Terra, 1996

. Contrato: Estrutura Milenar de Fundação do Direito Privado. In: Revista do Advogado, n. 68, Associação dos Advogados de São Paulo, dezembro/2002.

JUNQUEIRA DE AZEVEDO, Antonio. Negócio Jurídico. Existência, Validade e Eficácia. São Paulo: Saraiva, 2002. . Princípios do Novo Direito Contratual e Desregulamentação do Mercado Direito de Exclusividade nas Relações Contratuais de Fornecimento - Função Social do Contrato e Responsabilidade Aquiliana do Terceiro que Contribui para Inadimplemento Contratual. In: Estudos e Pareceres de Direito Privado. São Paulo: Saraiva, 2004.

MARTINS-COSTA, Judith. A Boa-Fé no Direito Privado. São Paulo: Revista dos Tribunais, 2000 .

. Um Aspecto da Obrigação de Indenizar: Notas para uma Sistematização os Deveres Pré-Negociais de Proteção no Direito Civil Brasileiro. In: Revista dos Tribunais, n. $867, \mathrm{jan} / 2008$.

. Novas Reflexões sobre o Princípio da Função Social dos Contratos. . Estudos de Direito do Consumidor - Coimbra, v. 7, p. 49-109, 2005

MARQUES, Cláudia Lima. Contratos no Código de Defesa do Consumidor: O Novo Regime das Relações Contratuais. 05 ed. São Paulo: Revista dos Tribunais, 2005. 
MARTÍNEZ, Gregório Peces-Barba. Curso de Derechos Fundamentales. Teoria General. Madrid: Universidad Carlos III, 1995

MAUSS, Marcel. Ensaio sobre a dádiva: Forma e razão da troca nas sociedades arcaicas. In: Sociologia e Antropologia. vol. I. São Paulo: Edusp, 1974

MORAES, Maria Celina Bodin de. O Conceito de Dignidade Humana: Substrato Axiológico e Conteúdo Normativo. In: SARLET, Ingo Wolfgang. Constituição, Direitos Fundamentais e Direito Privado. 02 ed. Porto Alegre: Livraria do Advogado, 2006

NABAIS, José Casalta. Solidariedade social, cidadania e direito fiscal. In: GRECO, Marco Aurélio; GODOI, Marciano Seabra de (Coord.). Solidariedade social e tributação. São Paulo: Dialética, 2005

NEGREIROS, Teresa. Teoria do Contrato: Novos Paradigmas. 02 ed. Rio de Janeiro: Renovar, 2006.

PERLINGIERI, Pietro. O direito civil na legalidade constitucional. Rio de Janeiro: Renovar, 2008

PONTES DE MIRANDA,. Tratado de Direito Privado. Tomo III.

REALE, Miguel. Visão Geral do Novo Código Civil. In: Revista de Direito Privado. v. 09. São Paulo: Revista dos Tribunais, 2002.

ROPPO, Enzo. O Contrato. Almedina: Coimbra, 1947, 2009.

SARMENTO, Daniel. Direitos Fundamentais e Relações Privadas. 02 ed. Rio de Janeiro: Lumen Juris, 2006.

SERPA LOPES, Miguel Maria de. Curso de Direito Civil. 06 ed., v. III, Rio de Janeiro: Freitas Bastos, 1996. 
SILVA, Caio Mario Pereira. Instituições de Direito Civil. v. III 11 ed., Rio de Janeiro: Forense, 2004.

SMITH, Adam. A Riqueza das Nações. Rio de Janeiro: Ediouro, 1986.

SOUZA JUNIOR, Cezar Saldanha. O Consensus do Estado Democrático Ocidental. São Paulo: USP, 1984.

TEPEDINO, Gustavo. Código Civil, os chamados microssistemas e a Constituição: premissas para uma reforma legislativa. In: TEPEDINO, Gustavo (org.). Problemas de Direito Civil Constitucional. Rio de Janeiro: Renovar, 2000.

TEPEDINO, Gustavo; BARBOZA, Heloisa Helena; MORAES, Maria Celina Bodin de. Código Civil Interpretado Conforme a Constituição da República. v. II. Rio de Janeiro: Renovar, 2006.

TIMM, Luciano Benetti; JOBIM, Eduardo. A arbitragem, os contratos empresariais e a interpretação econômica do direito. Direito e Justiça: Revista da Faculdade de Direito da Pontifícia Universidade Católica do Rio Grande do Sul, Porto Alegre , v.33,n.1, p.80-97, jan. 2007.

TIMM, Luciano Benetti. O Novo Direito Contratual Brasileiro. Rio de Janeiro: Forense, 2008.

Direito, Economia e a Função Social do Contrato: em busca dos verdadeiros interesses coletivos protegíveis no mercado de crédito. In: Revista de Direito Bancário e do Marcado de Capitais, v. 33, São Paulo, 2006.

WEBER, Max. A Ética Protestante e o Espírito do Capitalismo. São Paulo: Companhia das Letras, 2005 


\section{GÊNERO, SEXUALIDADES E DIREITO ${ }^{1}$}

\section{APRESENTAÇÃO}

Longas trilhas foram percorridas até a inserção do Grupo temático "Gênero, direito e sexualidade no XXV Congresso do CONPEDI em Curitiba de 07 a 10 de dezembro de 2016. Desde então é possível perceber que a cada evento o grupo cresce quantitativa e qualitavamente trazendo discussões extremamente relevantes sobre as questões de gênero e o constante desafio de reivindicação dos direitos humanos das mulheres e de pessoas e grupos sexualmente discriminados. Com o referido Grupo temático no VIII Encontro Internacional do CONPEDI Zaragoza - ES é um momento de grande comemoração por mais uma conquista de mulheres e homens que lutam pela igualdade de gênero. Não se pode esquecer também a importância e oportunidade de troca de experiências com docentes e discentes de outros países para que as discussões sobre Gênero e sexualidade, aumentem e mobilizem os movimentos e a necessidade de se pensar as articulações com o Direito em tempos de extrema vulnerabilidade.

O Grupo de Trabalho sobre Gênero, sexualidade e Direito do CONPEDI Zaragoza - ES foi um fórum interessante, onde foram discutidos temas de atualidade que requerem profundo debate doutrinal e social. Por um lado, falou-se da necessidade de entender o desenvolvimento como algo mais do que o crescimento econômico e a necessidade da participação ativa das mulheres nesse desenvolvimento social. Assim, a contribuição das mulheres é fundamental para a realização de todos os objetivos de desenvolvimento sustentável das Nações Unidas.

Nesse sentido, a sociedade como um todo deve defender os direitos de todas as pessoas que são discriminadas por causa de seu gênero ou sexualidade. Deve-se notar que no Brasil a mudança de nome e gênero das pessoas transgênero no Registro Civil pode ser feita sem necessidade de cirurgia, tendência que o Tribunal Europeu de Direitos Humanos segue em sua recente jurisprudência.

No entanto, em muitos países europeus, uma avaliação médica ou psicológica ainda é necessária para modificar o Registro Civil, por isso seria interessante que esses Estados sigam o exemplo do Brasil. As obrigações dos médicos nesse contexto também foram descritas. É necessário ser

\footnotetext{
${ }^{1}$ Nota Técnica: Os artigos que não constam neste livro foram selecionados para publicação na Plataforma Index Law Journals, - http://indexlaw.org/index.php/conpedireview/index.
} 
preciso no uso dos termos dado que a opção por uma identidade de gênero específica não pode ser denominada patologia.

Também é necessário observar que, apesar dos avanços que têm dado tanto a este respeito, para conseguir uma proteção eficaz dos direitos das pessoas transgênero também tem procurado soluções para outros problemas, como a falta de visibilidade na área política ou os ataques violentos propiciados pela transfobia, porque o reconhecimento da mudança de gênero é apenas um primeiro passo para a inclusão autêntica.

Por fim, é possível perceber que os trabalhos apresentados trouxeram reflexões teóricas e dados apresentados sobre múltiplas questões que contemplam relações entre gênero e sexualidade para se pensar o direito.

Coordenadores do GT:

Profa. Dra. Silvana Beline Tavares - UFG

Profa. Dra. Ana Gascón Marcén - UNIZAR 


\title{
A AUTONOMIA E A DIGNIDADE DA PESSOA HUMANA SOB A ÓTICA DA SITUAÇÃO DOS TRANSEXUAIS
}

\author{
Letícia da Silva Almeida \\ Universidade Fumec
}

Lucas Fortini Bandeira

Universidade Fumec

\begin{abstract}
Resumo
Considerando as dificuldades e discriminações enfrentadas diariamente pelos transexuais, este artigo estuda a partir dos Princípios da Autonomia Privada e a Dignidade da Pessoa Humana a situação jurídica e social dos transexuais. Para tanto, a pesquisa inicia com a exposição dos princípios e segue investigando aspectos relevantes da legislação brasileira e espanhola. Utilizado o método dedutivo, por meio da pesquisa bibliográfica. $\mathrm{O}$ marco teórico está na dignidade da pessoa humana como preceito fundamental do Estado Democrático de Direito, na obra de Henrique Olegário Pacheco.
\end{abstract}

Palavras-chave: Autonomia Privada, Dignidade da Pessoa Humana, Estado Democrático, Transexuais.

\begin{abstract}
Resumen/Résumé
Considering the difficulties and discriminations faced daily by transsexuals, this article studies from the Principles of Private Autonomy and the Dignity of the Human Person the juridical and social situation of transsexuals. To do so, the research begins with the exposition of the principles and continues investigating relevant aspects of Brazilian and Spanish legislation. Used the deductive method, through bibliographic research. The theoretical framework lies in the dignity of the human person as a fundamental precept of the Democratic State of Law, in the work of Henrique Olegário Pacheco.
\end{abstract}

Keywords/Palabras-claves/Mots-clés: Private Autonomy, Dignity of human person, Democratic State, Transsexuals. 


\section{Introdução}

A transexualidade é um dilema enfrentado pela humanidade há milhares de anos. Com o avanço das discussões sociais, psicológicas, médicas, religiosas, éticas e morais os transexuais se tornaram, cada vez mais, alvo de polêmicas, e vários problemas surgiram nos meios social e jurídico os envolvendo, principalmente a discriminação.

Partindo do ponto de que todos têm direito à uma vida digna e de autodeterminação, o artigo analisará o tratamento dado aos transexuais no Brasil e Espanha. Através de uma leitura do Direito espanhol, explicitará a regulamentação dos direitos dos transexuais no país, fazendo um estudo comparado entre as duas nações e verificando se ambos os países cumprem com o Princípio da Dignidade Humana e a autonomia privada dos transexuais.

Foi utilizado o método dedutivo, por meio da pesquisa bibliográfica. O marco teórico está na dignidade da pessoa humana como preceito fundamental do Estado Democrático de Direito, na obra de Henrique Olegário Pacheco.

\section{A autonomia ao longo da história e sua manifestação na constituição brasileira de 1988}

A autonomia da vontade adveio do desenvolvimento do racionalismo, do liberalismo e do capitalismo. O liberalismo buscava conciliar liberdade e segurança por meio do contrato, e essa era a forma de exteriorização da vontade. Havia uma separação absoluta entre Direito Público e Direito Privado. A origem da expressão autonomia da vontade dá-se nesse contexto de tempos modernos.

Parte dos estudiosos vão invocar Kant, especificamente, a "Fundamentação da metafísica dos costumes" como o precursor da autonomia da vontade. Outra parcela de doutrinadores vai defender que a expressão veio das contribuições dos internacionalistas no século XIX. Fato é que, independentemente da corrente adotada, após a Revolução Francesa e o destaque dado a suas ideias de liberdade, igualdade e fraternidade, "a autonomia da vontade elevou-se à categoria de princípio do Direito e de fone das relações jurídicas” (RODRIGUES JUNIOR, 2004, p.118). 
Nesse contexto:

percebe-se que essa visão da autonomia da vontade, denominada "francesa" por Antônio Junqueira de Azevedo (1986, p. 77), corresponde a uma certa noção de liberdade ou de possibilidade conferida a cada pessoa para agir ou não agir, de um modo ou de outro. (RODRIGUES JUNIOR, 2004, p.118).

O contrato não passa de forma da pessoa dispor do que é seu conforme suas vontades, necessidades e interesses. A restrição à liberdade de contratação é violação do livre uso e disposição da propriedade. E é justamente nesse ponto que se encontra o paradoxo que a concepção traz em seu bojo: “A vontade individual estaria sendo autorizada pelo ordenamento jurídico" (destaques do autor) (RODRIGUES JUNIOR, 2004, p.119). Ela deixa de ser poder de fato para ser poder jurídico.

Ademais:

Percebe-se que a autonomia, qualificada apenas como um produto da vontade, revelou- se uma derivação reducionista do individualismo, esquecendo o substrato humanista que lhe deveria permear e, de modo inequívoco, abrindo o flanco para as críticas mais severas por sua posição tributária aos desígnios da lei. Durante todo o século XX, a autonomia da vontade estigmatizou-se por suas ligações com os princípios tradicionais dos contratos. (RODRIGUES JUNIOR, 2004, p.119).

De modo que "de fonte da liberdade contratual - e indiretamente da liberdade de contratar -, passou a autonomia a sofrer toda sorte de deblaterações doutrinárias, quase sempre seguidas de brados a que se lhes fossem impostos limites e contenções". (RODRIGUES JUNIOR, 2004, p.119).

Após a Segunda Guerra Mundial, com o surgimento do fascismo, nazismo, intervenção estatal na economia, quebrando o paradigma do século XIX, surgiu uma nova visão da autonomia da vontade: a autonomia privada. Porém, essa também foi substituída pela autonomia privada da vontade, com o intuito de superação do individualismo da autonomia da vontade e do "intervencionismo legal e judicial do Estado como forma de coibir os abusos da liberdade pelos particulares" (RODRIGUES JUNIOR, 2004, p.122).

A partir da autonomia privada da vontade, a autonomia é "destituída do simples caráter de suporte das relações patrimoniais ou obrigacionais" (RODRIGUES JUNIOR, 2004, p.124), e passa a ser mais facilmente conectada com a autodeterminação. Nas palavras de Rodrigues Junior (2004, p. 126): 
A autodeterminação, a seu modo, seria um poder juridicamente reconhecido e socialmente útil, de caráter ontológico, baseado numa abertura do homem para o mundo e suas experiências e solicitações sensíveis ou não. $O$ plano da autodeterminação estaria no poder de cada indivíduo gerir livremente a sua esfera de interesses, orientando a sua vida de acordo com as suas preferências (RIBEIRO,1999, p. 22).

Por essa concepção da autonomia privada, dá-se o autogoverno às pessoas mediante a pré-seleção de condutas conforme as normas constitucionais de dignidade da pessoa humana, de superação da discriminação e de educação para condutas boas, justas. Assim, a autodeterminação rege as condutas no plano individual com lastro constitucional ao realizar a dignidade da pessoa humana (art. $1^{\circ}$, III CR/88).

\section{O Direito Fundamental da Dignidade da Pessoa Humana e o Estado Democrático de Direito}

A dignidade da pessoa humana após os terrores da Segunda Guerra Mundial passou a figurar em diversos documentos internacionais, como a Declaração Universal dos Direitos dos Homens (1948), o que serve para demonstrar que esse princípio "está na origem dos direitos materialmente fundamentais e representa o núcleo essencial de cada um deles, assim os individuais como os políticos e os sociais" (BARROSO, 2009).

No Brasil, é direito fundamental previsto no art. $1^{\circ}$, inciso III da Constituição Federal da República (CR/88) e constitui um dos principais fundamentos do Estado constitucional brasileiro.

Roberto Barroso explica que a dignidade da pessoa humana significa que cada pessoa deve ser tratada como fim em si mesmo, e não como meio de realização de outras pessoas, seja coletivamente, seja individualmente. É princípio que abarca a proteção de um mínimo existencial, conceituado como "conjunto de bens e utilidades básicas para a subsistência física e indispensável ao desfrute dos direitos em geral" (BARROSO, 2009). Dentre esses bens e utilidades encontra-se o direito à saúde, e aquém do patamar descrito acima, mesmo que haja sobrevivência, não há dignidade.

O direito da dignidade da pessoa humana se desdobra nos direitos da personalidade, reconhecidos a todos os cidadãos e oponíveis às demais pessoas e ao Estado. Esses direitos se dividem em direitos à integridade física, que compreende dentre outros o direito à vida e ao próprio corpo; e direitos à integridade moral, que envolve o direito à honra, à imagem e à 
privacidade. "Dele se extrai o sentido mais nuclear dos direitos fundamentais, para a tutela da liberdade, da igualdade e para promoção da justiça” (BARROSO, 2009, p.252, 253).

O Estado Democrático de Direito tem como fundamento regras e princípios constitucionais garantidoras. É sob a égide do Estado Democrático de Direito que se preza pelas garantias fundamentais do ser humano. O artigo $1^{\circ}$, inciso III da Constituição da República Federativa do Brasil estabelece o princípio da dignidade humana como fundamento do Estado Democrático de Direito.

Para melhor compreensão do instituto do Estado Democrático de Direito, é mister esclarecer a existência do próprio Estado. A criação do Estado se deu em função de evidenciada a necessidade de garantir a proteção dos interesses do homem. Para alcançar a ideia de Estado Democrático de Direito que como é conhecido atualmente foi necessário passar por enorme processo de evolução de maneira que a sociedade evoluiu e se organizou ao longo dos séculos.

Em função da arbitrariedade e abuso de poder dos reis absolutistas ocorreu revolta em algumas classes sociais e políticas daquela época, que acabaram por buscar novos modelos de organização social para a proteção da coletividade e a individualidade de cada ser. Assim, com a submissão do império a lei, a criação e divisão dos três poderes e a garantia dos direitos individuais, nasceu o Estado de Direito. O Estado Social de Direito, também conhecido como Estado administrador, caracteriza-se no propósito de integrar e reduzir as desigualdades com intuito de promover o bem-estar social geral, numa sociedade de massas com conflitos sociais.

O constituinte ao redigir o dispositivo mencionado reconheceu na dignidade pessoal a prerrogativa de todo ser humano em ser respeitado como pessoa, de interesses que dizem respeito à vida humana, sejam direitos políticos, culturais econômicos ou pessoais.

Sobre o tema, cumpre destacar o entendimento de Nelson Rosenvald:

Temos ainda que a Constituição da República de 1988 adotou uma decisão política fundamental: inserir o princípio da dignidade da pessoa humana como princípio fundamental da República Federativa, proporcionando um conteúdo substancial ao sistema jurídico. Essa meta é uma demonstração da subserviência do Estado ao ser humano; da posição de anterioridade da pessoa ao ordenamento e, principalmente, da supremacia dos valores, agora positivados em princípios. (ROSENVALD, 2005, p. 51). 
Destaca-se o conceito de Estado Democrático de Direito, pela obra de Sérgio Henriques Zandona Freitas:

\begin{abstract}
O Estado Democrático de Direito não representa simplesmente o resultado dos elementos constitutivos do Estado de Direito e do Estado Democrático, mas uma evolução histórica que atravessou os estágios do Estado de Polícia, do Estado liberal e do Estado social, com a superação de grande parte das contradições e das deficiências dos sistemas anteriores, até atingir o modelo contemporâneo que inspira várias das atuais Constituições estrangeiras, além da brasileira de 1988. [...] Os direitos fundamentais deixam de ser casuísticos e emergemse como valores essenciais do sistema jurídico-político, condicionantes do método de sua interpretação, passando de meros direitos de defesa ante o Estado para transformarem-se em direito de participação do cidadão e de prestações do Estado. (FREITAS, 2011, p. 479).
\end{abstract}

Assim, no Estado Democrático de Direito, o conjunto de normas da ordem jurídica são fundamentais para evitar os abusos de direitos, que podem vir à serem cometidos, bem como para inibir a violação de garantias individuais e fundamentais da sociedade.

\title{
4. Os Transexuais
}

Após a breve explanação da autonomia e da dignidade da pessoa humana como princípios que regem a ordem constitucional democrática brasileira, passa-se ao estudo da transexualidade, para ao final explicar-se como as pessoas transexuais têm sua autonomia e dignidade violadas pelo direito.

O termo transexualismo foi utilizado pela primeira vez em 1954, em uma revista norte-americana para identificar uma síndrome caracterizada pela incompatibilidade do sexo morfológico e do sexo psicológico, ou seja, entre a aparência dos órgãos sexuais e da identidade sexual (BARBOSA, 2017, p.146). Apesar de o termo ter aparecido somente na década de 1950, a transexualidade sempre existiu, seja na Antiguidade Clássica, na Idade Média, seja entre os povos ameríndios ou entre os povos orientais. No entanto, a aceitação social de tais pessoas, desde épocas remotas até atualmente, depende de cada cultura. (LIMA, 2001).

Por sua vez, o Código Internacional de Doenças (CID) apresenta a transexualidade como "Transtorno de Identidade de Gênero", estabelecendo que: 
para sua caracterização é necessário além da incompatibilidade narrada no parágrafo anterior, a presença de um desejo de se livrar das genitálias e obter as do sexo oposto. $\mathrm{O}$ anseio gerado é tão grande que reflete em consequências gravíssimas, dificultam a convivência por causar angústia, depressão, automutilação e até mesmo tentativa de suicídio. (BARBOSA, 2017, p.146).

O diagnóstico do "transexualismo" é feito em duas etapas, conforme os padrões da Associação Internacional da Disforia Sexual Harry Benjamin. "Primeiro deve ser verificada a persistência do mal-estar no indivíduo adulto em relação a seu sexo biológico” (BARBOSA, 2017, p.146). Depois é necessário verificar a presença, “por no mínimo dois anos, do desejo de se ver livre das características sexuais primárias e secundárias, e de adquirir as do sexo oposto" (BARBOSA, 2017, p.146). É importante esclarecer que a transexualidade independe da orientação sexual.

O problema de tal classificação e caracterização reside no fato de que nem todo transexual tem repulsa por seus órgãos. Muitos aceitam viver com o físico com que nasceram, pois nem sempre querem passar por uma cirurgia ou tomar hormônios para se parecerem com o sexo com que se identificam. Além disso, vários transexuais não se sentem confortáveis com a ideia de ter um tratamento hormonal com diversos efeitos colaterais, e nem sentem necessidade de mudar sua aparência.

No entanto, a grande maioria dos países e da comunidade médica considera a transexualidade como doença, daí a utilização da palavra transexualismo. É o que explica, por exemplo, DINIZ (2008), LIMA (2001), NICACIO (2006).

Grande parte dos médicos entende que, independentemente da origem, o tratamento psicológico não é suficiente para corrigir o transtorno. É necessária a realização da cirurgia de redesignação de sexo, e demais cirurgias, como rinoplastia, modificação nas maçãs do rosto e no pomo-de-adão, além de cirurgia para corrigir a voz, implantação de ovários e trompas, e ainda tratamento hormonal, para que o transexual, que assim deseje, possa ter compatibilizado seu sexo biológico com o psicológico, de modo a ter uma vida digna (BARBOSA, 2017).

Quanto aos sintomas para caracterizar uma pessoa como portadora da síndrome de Identidade de Gênero, é importante apontar que muitas vezes se devem à discriminação e dificuldades que encontram no dia a dia. (BARBOSA, 2017).

A definição da transexualidade como doença não é algo pacifico dentro da comunidade. "Muitos transexuais não se sentem confortáveis de serem estigmatizados como doentes mentais, e defendem que somente são diferentes” (BARBOSA, 2017, p.147). 
Nesse contexto, destaca-se que a França foi o primeiro país a retirar, em seu território, a classificação da transexualidade como transexualismo, fazendo com que lá a transexualidade não fosse mais considerada Transtorno de Identidade de Gênero.

Restando explicado quem são os transexuais, parte-se a seguir para a participação deles no cenário jurídico-social brasileiro.

\section{A transexualidade no ordenamento jurídico brasileiro e espanhol}

No Brasil a regulação da cirurgia de redesignação de sexo é feita pelo Conselho Federal de Medicina desde 1997 com a publicação da Resolução n. 1482. A partir de tal Resolução, quando a cirurgia fosse feita dentro de seus parâmetros, não poderia mais ser considerada crime de lesão corporal, previsto no art.129 do Código Penal Brasileiro.

Após alguns anos, veio a Resolução 1652/02. A nova regulamentação prevê que a cirurgia de transgenitalização para a modificação do sexo feminino para o masculino, somente pode ser feita em hospital público ou universitário com atividades de pesquisa. Contudo, o art. $6^{\circ}$, dispõe que, quando se tratar de troca do sexo masculino para o feminino, a operação pode ser feita tanto em hospital privado quanto em hospital público, independentemente de possuírem atividade de pesquisa.

$\mathrm{O}$ art. $3^{\circ}$ é onde se encontram os requisitos para o diagnóstico de transexualidade. $\mathrm{E}$ apesar de prever a idade mínima como de 21 anos, essa deve ser considerada como de 18 anos. Isso porque quando a Resolução foi editada vigorava o Código Civil de 1916, que previa a maioridade como 21 anos. Entretanto, em 2003 entrou em vigor o novo Código Civil, que passou a prever a maioridade aos 18 anos.

A Resolução que autoriza a cirurgia possui como base o art. 199 , paragrafo $4^{\circ}$ da Constituição brasileira, que coloca a cargo da legislação a regulamentação de condições e requisitos que facilitem a remoção de órgãos, tecidos e substâncias humanas para fins de tratamento.

Em 2008, o Ministério da Saúde publicou a portaria $n^{\circ} 1.707$ que instituiu no art. $1^{\circ}$ “o Processo Transexualizador a ser empreendido em serviços de referência devidamente habilitados à atenção integral à saúde aos indivíduos que dele necessitem", mediante a observação das condições estabelecidas na Resolução $n^{0}$ 1.652/02 do Conselho Federal de Medicina.

Devido ao art. $3^{\circ}$ da Portaria ${ }^{\circ} 1.707 / 08$, a Secretaria de Atenção à Saúde publicou a Portaria $n^{0} 457$, que por sua vez estipula as providências necessárias à estruturação e 
implantação do Processo Transexualizador no SUS, que foi redefinido e ampliado em 2013 pela Portaria $n^{\circ}$ 2.803/2013 que revogou a anterior face à decisão judicial na Ação Civil Pública no 2001.71.00.026279-9/RS, que versa sobre a implantação no SUS de cirurgias de readequação sexual.

Contudo, permitir que a regulamentação continue a ser feita pelo Conselho Federal de Medicina por meio de uma resolução, é aceitar que a legislação seja construída por um conselho profissional, ao invés de ser pelo Poder Legislativo, a quem a Constituição da República de 1988 deu a competência para a criação de normas. A importância de a regulamentação ser construída por esse Poder se deve à imprescindibilidade de observância ao devido processo legislativo, pois somente quando esse for observado a regulamentação será legítima, uma vez que será construída pelo povo, seja indiretamente através dos representantes escolhidos, seja diretamente pela participação popular por meio de audiências públicas, por exemplo.

Na hipótese de a transexualidade não ser mais considerada doença, não há razão para que os transexuais sejam impedidos de realizar a cirurgia, pois apesar de não ser mais tratamento, a operação nesses casos é necessária para garantir o livre desenvolvimento da personalidade.

Vale ressaltar que a cirurgia não pode ser tida como afronta a integridade física do transexual quando esse a deseja, pois é o modo mais efetivo de garanti-la tendo em vista que pode ocorrer automutilação e suicídio. Destarte, a vedação ao acesso a quem dela necessita é que feriria a proteção à integridade física.

Há que se considerar ainda que, como ensina NICACIO (2006), a Constituição brasileira ao estabelecer no art. $5^{\circ}, \S 2^{\circ}$ a vigência do Direito Internacional no Brasil quando referente a Direitos Humanos terminou por decretar a interpretação desses conforme a Declaração Universal dos Direitos do Homem. Como a Declaração institui o pleno desenvolvimento da personalidade humana, por ser a mudança do estado sexual referente a tal direito, não há motivo para sua proibição.

Nesse sentido a opinião consultiva $24 / 17$ da Corte Interamericana de Direitos Humanos:

[...] a Corte Interamericana deixa estabelecido que a orientação sexual e a identidade de gênero, assim como a expressão de gênero, são categorias protegidas pela Convenção. Por isso está proibida pela Convenção qualquer norma, ato ou prática discriminatória baseada na orientação sexual, identidade de gênero ou expressão de gênero da pessoa. Em consequência, nenhuma norma, decisão ou prática do direito interno, seja por parte das autoridades estatais ou por 
particulares, podem diminuir ou restringir, de modo algum, os direitos de uma pessoa à sua orientação sexual, sua identidade de gênero e/ ou sua expressão de gênero. (par. 78).

O reconhecimento da identidade de gênero pelo Estado é de vital importância para garantir o gozo pleno dos direitos humanos das pessoas trans, incluindo a proteção contra a violência, a tortura e maus tratos, o direito à saúde, à educação, ao emprego, à vivência, ao acesso a seguridade social, assim como o direito à liberdade de expressão e de associação. (CORTE, 2017).

Pelas normas de direito interno, por sua vez, o Código Civil de 2002 autoriza no art.13 a disposição do corpo quando houver exigência médica, ou seja, quando for necessária a proteção da vida ou da integridade psicofísica. Quando o transexual sente necessidade de modificar sua aparência, a cirurgia é imprescindível para garantir proteção à sua integridade psicofísica, portanto o art. 13 é mais uma disposição legal que, juntamente com o Princípio da Dignidade da Pessoa Humana, serviria para fundamentar a autorização da realização do procedimento.

Não é só a cirurgia de transgenitalização que não possui regulamentação no Brasil, a legalidade da cirurgia, os acessos à informação sobre a mudança de gênero também não possuem. Assim, termina por ser o Poder Judiciário o responsável por garantir ou negar direitos a esses cidadãos, o que faz com que todos os transexuais passem por um longo, estressante e incerto processo judicial para ao final ter um direito garantido ou não. Isso porque como não há lei, os médicos não podem realizar a cirurgia fora do estabelecido pelo Conselho Federal de Medicina, sob pena de cometerem crime de lesão corporal; e os Registros Civis em quase todos os casos não aceitam modificar o prenome e o sexo sem decisão judicial, pois não é previsto na Lei de Registros Públicos a autorização para a mudança do registro do transexual.

Após a regulamentação pelo Conselho Federa de Medicina da cirurgia de transgenitalização o entendimento mudou, passando a defesa da desnecessidade de autorização judicial para fazer a operação, tendo como premissa o fato de serem exigidos previamente à sua execução uma série de exames médicos e psicológicos, não sendo de competência do magistrado a análise de tais questões. (SÁ; NAVES, 2011).

Não obstante, os transexuais continuavam a pedir permissão ao Poder Judiciário para a concretização da cirurgia, com a intenção de, futuramente, a sentença favorável facilitar o processo para alteração do registro civil.

Diante da ausência de qualquer regulamentação, em 2009, foi interposta, pela Procuradoria Geral da República no Supremo Tribunal Federal, a Ação Direta de 
Inconstitucionalidade (ADI) $\mathrm{n}^{\mathrm{o}} 4275$ requerendo a interpretação conforme à Constituição ao art.58 da Lei 6.015/73 (Lei de Registros Públicos) para que seja reconhecido o direito dos transexuais trocarem o prenome e sexo no registro civil, sem necessidade de realização de cirurgia de redesignação de sexo, tendo como suporte os Princípios Constitucionais da Dignidade da Pessoa Humana, de proteção contra a discriminação, de igualdade, de liberdade e privacidade.

Nesse contexto, encontrava-se decisões judiciais que permitiam a mudança do prenome independentemente da cirurgia de transgenitalização; acórdãos que como o do Recurso Especial 1.008.398/SP $\mathrm{SP}^{1}$, permitiu a alteração do prenome e sexo sem qualquer averbação no registro civil; decisões que permitiram a modificação do registro civil, mas exigiu que constasse no Registro a expressão "transexual" como garantia de que o transexual só contrairia casamento com pessoa do sexo oposto e evitaria que terceiro incorresse em erro ${ }^{2}$. Haviam ainda julgados que concediam o direito de transexual ter o nome no Registro Civil alterado conforme o gênero escolhido, sem a necessidade de cirurgia de transgenitalização ${ }^{3}$, mas que negava a alteração do gênero, devido à não realização da cirurgia de mudança de sexo.

Outrossim, os julgados que se mantiveram como maioria desde a década de 1970, negavam o pedido de retificação do prenome e do sexo, pelos mais diversos argumentos, por exemplo, proteção de terceiros, prevalência do sexo biológico, pela cirurgia não ser capaz de fazer com que o transexual se enquadre perfeitamente no sexo oposto. No entanto, no Brasil, muito recentemente, em março de 2018, o Supremo Tribunal Federal $(\mathrm{STF})$, passou a garantir a possibilidade de que transgêneros alterem o nome e sexo no Registro Civil, o sem a exigência de comprovação por meio de laudos, pareceres, modificação corporal ou até mesmo, independe de autorização judicial. Basta apresentar a autodeclaração da vontade de modificação em Cartório para o procedimento ser realizado. Portanto, não há mais a necessidade de ingressar com ação judicial para garantir a alteração no Registro Civil.

$\mathrm{Na}$ Espanha, a Lei que permite aos transexuais a retificação do nome e sexo no Registro Civil existe desde 2007, quando o Congresso local aprovou a Lei prevendo a

\footnotetext{
${ }^{1}$ Apelação Cível No 0035945-20.2009.8.26.0071, $3^{\text {a }}$ Câmara de Direito Privado do TJSP, Relator: Donegá Marandini, Julgado em 28/09/2010. PARANÁ, 1994. TJPR, Primeira Câmara Cível, Apelação Cível n.30.019-8, Rel. Des. Osiris Fontoura,

${ }^{2}$ RIO GRANDE DO SUL, 2006. Apelação Cível № 70013909874, Sétima Câmara Cível, Tribunal de Justiça doRS, Relator: Maria Berenice Dias, Julgado em 05/04/2006). Data do julgamento: 08/11/1994

${ }^{3}$ SERGIPE, 2012. APELAÇÃO CÍVEL No 3976/2012, $1^{\circ}$ Vara Cível de Estância, Tribunal de Justiça do Estado de Sergipe, Desa. Maria Aparecida Santos Gama da Silva, Relatora, Julgado em 09/07/2012
} 
desnecessidade de cirurgia, no entanto, havendo exigência de laudo médico com diagnóstico de "disforia de gênero", além de comprovação de que tenha havido tratamento, por pelo menos dois anos, para adequar seu físico ao sexo no qual se identifica. "Até o momento, os transexuais espanhóis só podiam mudar seus dados nos documentos oficiais se tivessem se submetido a uma operação de mudança de sexo e obtivessem uma sentença judicial propícia" (G1 MUNDO, 2007).

A Lei brasileira e espanhola representou para as pessoas transexuais enorme avanço, facilitando os tramites para alteração do nome e sexo.

\section{A violação à autonomia e à dignidade da pessoa humana dos transexuais}

Após a exposição teórica da autonomia, da dignidade da pessoa humana, da explicação de quem são os transexuais e da situação em que eles se encontravam à mercê da moral do juiz que for o responsável por julgar seu caso, o presente item vem demonstrar o impacto que a violação da autonomia e da dignidade da pessoa humana impacta na vida dos transexuais.

Conforme Erik Jayme (1999, p. 29) citado por Rodrigues Junior (2004, p.127), a pós modernidade traz como um de seus valores básicos o pluralismo, o reconhecimento da "pluralidade de estilos de vida e a negação de uma pretensão universal à maneira própria de ser”, a Constituição brasileira de 1988, nesse contexto, traz consigo a inclusão social, econômica, jurídica do outro no sentido de que "as fronteiras da comunidade estão abertas a todos - também e justamente àqueles que são estranhos um ao outro - e querem continuar sendo estranhos". (RODRIGUES JUNIOR, 2004, p.127).

Em outras palavras, através do direito de autodeterminação da aparência de seu corpo, os transexuais têm a porta aberta tanto na sociedade, quanto no mundo jurídico para realizarem as mudanças que entenderem necessárias para a realização de seu bem-estar, mesmo que isso signifique ir contra ao que uma maioria entende por "normal". Já ao Estado, cabe a criação políticas públicas e outros de mecanismos para evitar abusos e injustiças, quando a pessoa toma decisões "na sua esfera particular de acordo com seus próprios interesses e preferências" (FABRO E RECKZIEGEL, 2014, p.179), de modo que ela não fique subjugada ao preconceito, à discriminação, a viver sem poder expressar quem ela realmente é. 


\section{Conclusão}

A dignidade da pessoa humana é direito fundamental previsto no art. $1^{\circ}$, inciso III da Constituição Federal da República do Brasil e constitui um dos principais fundamentos do Estado Democrático de Direito brasileiro. A autodeterminação ou autonomia da vontade privada também possui base constitucional no art. $1^{\circ}$, III da CR/88.

Tais princípios implicam em Direitos da Personalidade, como integridade física, integridade moral, honra, imagem e privacidade, e a partir de tais princípios algumas decisões judiciais brasileiras defendia o direito de mudança de sexo e prenome pelos transexuais, e outras, a grande maioria, ainda negava a possibilidade de alteração de nome e sexo no Registro Civil, violando a autonomia e a dignidade dessas pessoas.

Fato é que por não haver lei que regulamente os direitos de realização de cirurgia de transgenitalização e alteração de prenome e sexo no registro, tais questões eram regulamentadas pelo Conselho Federal de Medicina ou por decisões do Poder Judiciário, o que, como já explicado, traz um tratamento diferenciado para pessoas que estão na mesma conjuntura e viola também a segurança jurídica.

No entanto, após uniformização do entendimento pelo Supremo Tribunal Federal brasileiro e pelo Congresso Espanhol a situação agora revela respeito mínimo a vontade dos transexuais, além de segurança jurídica.

Para tanto, ainda cabe por parte do Estado a implementação políticas públicas, programa de conscientização social, projetos de acompanhamento familiar no intuito de auxiliar famílias a se relacionar melhor, evitando que se rompesse tal vínculo. Os sindicatos também poderiam instituir medidas para proteção de transexuais no âmbito trabalhista, evitando as dificuldades que esses encontram de acesso a emprego, comentários pejorativos por parte de colegas, e demissões causada pela mudança de sexo.

Resta demonstrado assim, que a atuação do Poder Judiciário brasileiro e Legislativo espanhol é meramente um passo na concessão de dignidade aos transexuais. São necessárias ainda políticas públicas, ações sociais de inclusão, para que os transexuais possam exercer livremente sua autodeterminação e possam ter uma vida digna, uma vez que nada adianta uma lei que não se enquadre no que a sociedade aceita, e para aceitar é preciso antes entender. 


\section{Referências bibliográficas}

ARAUJO, Luiz Alberto David. A proteção constitucional do transexual. São Paulo: Saraiva, 2000.

ASSOCIAÇÃO ILGA DE PORTUGAL. Sabemos o que somos. Pessoas. Out. 2011.

BARBOSA, Fernanda Lopes. As fundamentações dos acórdãos do Tribunal de Justiça de Minas Gerais sobre a transexualidade: a cirurgia de redesignação sexual e a alteração no registro do prenome e do sexo. In: RODRIGUES JUNIOR, Walsir Edson (Org.). Direito das famílias e das sucessões: Novas Tendências. Belo Horizonte: D’Plácido, 2017.

BARROSO, Luís Roberto. Curso de Direito Constitucional Contemporâneo. Os conceitos fundamentais e a construção do novo modelo. São Paulo: Saraiva, 2009.

BRASIL, Constituição (1988). Constituição da República Federativa do Brasil. Disponível em: <http://www.planalto.gov.br/ccivil_03/constituicao/constituicao.htm>. Acesso: 10 mar.2018.

BRASIL. Ministério da Saúde. Portaria nº 1.707, de 18 de agosto de 2008. Diário Oficial da união: Brasília.

BRASIL. Ministério da Saúde. Portaria nº 2.803, de 19 de novembro de 2013. Diário Oficial da União: Brasília.

BRASIL. Superior Tribunal de Justiça. Recurso Especial 1.008.398/SP. Relator: Min. NANCY ANDRIGHI. Brasil, 07 dez. 2009.

CORTE, Interamericana de Direitos Humanos. Opinión Consultiva OC-24/17. Costa Rica. 2017. Disponível em: < http://corteidh.or.cr/docs/opiniones/seriea_24_esp.pdf >. Acesso em: 13 maio 2018. 
CASTAGNOLI, Cristina. Transgender Persons' Rights in the EU Member States.

European Parliament, Brussels 2010. Disponível em:

http://www.ipolnet.ep.parl.union.eu/ipolnet/cms>. Acesso em: 25 fev. 2018.

DINIZ, Maria Helena. O Estado atual do biodireito. 8. ed. São Paulo: Saraiva, 2012.

DUARTE, Maria Luísa. O estatuto de cidadão da União e a (não) discriminação em razão da orientação sexual. In: Separata de Estudos em Memória do Professor Doutor António Marques dos Santos. Coimbra: Almedina, 2006. v. II.

FABRO, Roni Edson. RECKZIEGEL, Janaína. Autonomia da vontade e autonomia privada no sistema jurídico brasileiro. 2014. Disponível em: < https://editora.unoesc.edu.br/index.php/uils/article/view/4402 >. Acesso em: 10 maio 2018.

FREITAS, Sérgio Henriques Zandona. Responsabilidade do Estado. In: MOTTA, Carlos

Pinto Coelho. Curso prático de direito administrativo. 3. ed. Belo Horizonte: Del Rey, 2011.

GARCIA, Emerson. Conflito Entre Normas Constitucionais: esboço de uma teoria geral. Rio de Janeiro: Lumen Juris, 2008.

G1 MUNDO. Lei Espanhola Permitirá que Transexuais Mudem de Nome e de Sexo sem

Cirurgia. S.L. 2007. Disponível em: <http://g1.globo.com/Noticias/Mundo/0,AA14743885602,00.html>. Acesso em: 10 maio 2018.

MATOS, Graziella Pinheiro Godoy. Alteração do registro civil face à mudança de sexo.

Revista Síntese direito de família, Porto Alegre : IOB, v.14, n.73, pg 09-27 2012

NAVES, Bruno Torquato de Oliveira; SÁ, Maria de Fátima Freire de. Manual de Biodireito. 2. ed. Belo Horizonte: Del Rey, 2011. 
NICACIO, Gabriela Autran Dourado Dutra. A participação de atletas que passaram por cirurgia de mudança de sexo nas competições. In: Desporto e Direito: Revista Jurídica do Desporto. - Ano IV, nº 10, p. 43,56, 2006.

PACHECO, Henrique Olegário. Transexualismo e a dignidade da pessoa humana: possibilidade jurídica de mudança de nome e de sexo no registro civil após operação transexual. Belo Horizonte: Do Autor, 2005.

PARANÁ. Tribunal de Justiça. Apelação Cível 30.019-8, Relator: Des. Osiris Fontoura. Paraná, 08 nov. 1994.

PERES, Ana Paula Ariston Barion. Transexualismo: o direito a uma nova identidade sexual. Rio de Janeiro: Renovar, 2001.

RIO GRANDE DO SUL. Tribunal de Justiça. Apelação Cível 70013909874. Relator: Maria Berenice Dias. Rio Grande do Sul, 05 abr. 2006.

RODRIGUES JUNIOR, Otavio Luiz. Autonomia da vontade, autonomia privada e autodeterminação. Notas sobre a evolução de um conceito na Modernidade e na Pósmodernidade. Brasília a. 41 n. 163 jul./set. 2004. Disponível em: $<$ http://www2.senado.leg.br/bdsf/item/id/982 >. Acesso em: 25 fev. 2018.

ROSENVALD, Nelson. Dignidade Humana e boa-fé no Código civil. São Paulo: Saraiva, 2005 .

ROSITO, Francisco. Teoria dos Precedentes Judiciais: racionalidade da tutela jurisdicional. Curitiba: Juruá, 2012.

SÁ, Maria de Fátima Freire de. Aplicação dos princípios no biodireito. Belo Horizonte: PUC Minas Virtual, 2002.

SANTOS, Maria Ignez Franco. A identidade pessoal e a cirurgia de redesignação de sexo. In: CAMPOS, Diogo Leite de (Coord.). Estudos sobre o direito das pessoas. Coimbra: Almedina, 2007. 
SÃO PAULO. Tribunal de Justiça. AC 2005.001.17926, Relator: Des. Nascimento Povoas Vaz, São Paulo, 22 de novembro de 2005.

SÃO PAULO. Tribunal de Justiça. Apelação Cível 0035945-20.2009.8.26.0071. Relator: Donegá Marandini, São Paulo, 28 de setembro de 2010.

SCRECCIA, Elio. Os direitos da vida humana: "Manual de Bioética": Transexualismo. 2003. Disponível em: $<$ http://www.pr.gonet.biz/kb_read.php?num=1075\&head=0 $>$. Acesso em: 25 fev. 2018.

SECRETARIA DE COMUNICAÇÃO SOCIAL DA PROCURADORIA GERAL DA REPÚBLICA. Ação pede que seja dada interpretação ao artigo 58 da Lei $\mathbf{n}^{\circ} 6.015 / 73$ conforme a Constituição. Disponível em: <http://noticias.pgr.mpf.gov.br/noticias/noticiasdo-site/copy_of_constitucional/pgr-propoe-adi-para-que-transexuais-tenham-direito-a-mudarnome-e-sexo-no-registro-civil>. Acesso em: 25 fev. 2018.

SERGIPE. Tribunal de Justiça. Apelação Cível 3976/2012. Relator: Maria Aparecida Santos Gama Da Silva. Sergipe, 09 jul. 2012.

SILVA NETO, Maria Luísa Alves da. O direito fundamental à disposição do próprio corpo (A relevância da vontade na configuração do seu regime). Coimbra: Almedina, 2004. 


\title{
A CONDIÇÃO DE AGENTE DAS MULHERES COMO PEÇA FUNDANTE DO DESENVOLVIMENTO
}

\author{
Paula Isabel Nóbrega Introine Silva \\ Centro Universitário de João Pessoa - UNIPÊ \\ Hertha Urquiza Baracho \\ Centro Universitário de João Pessoa - UNIPÊE
}

\section{Resumo}

A busca pelo desenvolvimento é a mola propulsora do mundo contemporâneo. Amartya Sen, utilizando o aumento das liberdades dos indivíduos para que consigam o maior número de oportunidades e capacidades, para atingirem o desenvolvimento. Todavia para chegar a esse momento tem-se que superar as desigualdades inseridas na sociedade, em especial a discriminação de gênero que as mulheres sofrem, passando por insuficiências econômicas, de saúde, educacionais, de liderança e diversas liberdades, pois só com a quebra desse paradigma e com a o aumento da capacidade de agente das mulheres é que se dará o real desenvolvimento sustentável.

Palavras-chave: Desenvolvimento, Liberdades, Igualdade, Mulheres, Empoderamento.

\begin{abstract}
Resumen/Résumé
Development pursuit is the main objective of contemporary world. Amartya Sen stand up for this balance, using the individual growing freedom as a mean to achieve a bigger number of opportunities and competencies leading to development. However, to reach this moment, is necessary overcome social inequalities, specially gender discrimination, economical, health and educational insufficiencies, because breaking this paradigm and increasing women participation is the only way to have a real sustainable development.
\end{abstract}

Keywords/Palabras-claves/Mots-clés: Development, Freedoms, Equality, Women, Empowerment. 


\section{Introdução}

O direito humano ao desenvolvimento (DHD) está totalmente interligado ao princípio da dignidade da pessoa humana, uma vez que o ser humano só conseguirá ter de fato uma vida digna se seus direitos sociais, econômicos, culturais, políticos e ambientais forem garantidos ou pelo menos protegidos, observando sempre um mínimo social adequado.

Todavia, o cenário internacional e nacional não retrata tal preocupação, pois falsas medidas ou fundamentos de uma proteção aos direitos fundamentais e ao desenvolvimento humano são distorcidos quando há a presença marcante da busca por um crescimento econômico. Exemplo disso são as reformas trabalhistas e sociais que o Brasil vem adotando nos últimos anos, bem como das atitudes internacionais de não tolerância, discriminação, desregulamentação de direitos sociais, abusos e retrocesso na proteção ambiental, diminuição de atitudes e políticas democráticas. Reforçando assim a necessidade de debates sobre o direito humano ao desenvolvimento e à proteção das minorias mais desfavorecidas.

Diante desse retrato social, os grupos vulneráveis da sociedade são sempre os mais atingidos, como por exemplo as mulheres, que ocasionam o fenômeno da feminização da pobreza, surgindo a necessidade de além das políticas universais, de estratégias específicas que tendam a uma maior proteção dessas vítimas preferencias de exclusão, para assim aumentar suas liberdades e o seu bem-estar em sentido amplo.

Dentre os autores que tratam sobre a questão do desenvolvimento humano e do próprio sentido da justiça, tem-se o economista Amartya Sen, que propõe a análise da questão da desigualdade de gênero comungada com assuntos relacionados com pobreza, discriminação, marginalização, carência de oportunidades, insegurança econômica, política e social, que geram uma consequente ausência de liberdade, repercutindo no desenvolvimento de toda sociedade.

Através de uma análise empírica, Sen tem uma visão diferente e avançada sobre o conceito de desenvolvimento. Suas contribuições teóricas sobre o desenvolvimento, tentam demonstrar que esse processo não está ligado ao crescimento econômico, ou à distribuição de riquezas, mas às oportunidades que um país oferece à sua população de fazer escolhas, de exercer seus direitos e sua cidadania, com a garantia dos direitos básicos, como saúde, educação, segurança, moradia, cultura etc. Sen se preocupa com uma nova compreensão dos conceitos de miséria, fome, pobreza e bem-estar e para ele o desenvolvimento está estreitamente ligado à extensão das liberdades substantivas. 
Portanto, diante dos aspectos jurídicos, filosóficos e sociológicos, surge o seguinte questionamento: Por que a condição de agente das mulheres é importante para o desenvolvimento? Para que se possa responder tal indagação, o presente estudo tem como prisma analisar a importância da capacidade de agente das mulheres como fator necessário ao desenvolvimento.

Para elaboração do artigo foi utilizado o método qualitativo e descritivo, utilizando a pesquisa bibliográfica e dados estatísticos trazidos pela Organização das Nações Unidas (ONU).

O artigo procura fazer uma reflexão sobre a condição de agente das mulheres como peça fundante do desenvolvimento numa leitura ousada e inovadora segundo o raciocínio de Sen. Além dele, outros economistas veem, também a necessidade da elaboração de um novo modelo, um protótipo em que todas as variáveis sejam consideradas, em que as esferas econômicas, sociais e políticas sejam integradas e em que as democracias sejam enaltecidas.

Sob essa vertente e pautando-se nas proposições de Amartya Sen é que o texto do presente artigo se propõe a instigar a discussão entre algumas teorias existentes sobre o tema no mundo contemporâneo. Assim, o artigo será dividido em cinco seções, incluindo-se a introdução. A segunda seção abordará o desenvolvimento como liberdade, a terceira se debruçará sobre a desigualdade de gênero no cenário internacional, enquanto a quarta discutirá a necessidade da condição de agente das mulheres para o desenvolvimento, para ao final se chegar às considerações finais sobre o tema proposto.

\section{O desenvolvimento como liberdade}

Estamos caminhando cada vez mais para uma crise insustentável, pois mesmo com todo conhecimento do que seria entendido como desenvolvimento nos dias de hoje, segue o capitalismo ditando o rumo e as políticas públicas que devem ser priorizadas, com isso, o meio ambiente e os direitos sociais são colocados à margem, gerando um aumento das desigualdades e uma crise socioambiental e moral.

Com o aumento das desigualdades, os grupos vulneráveis que já sofrem em uma situação de maior equilíbrio, acabam sendo ainda mais atingidos, como no caso das mulheres. Surge com isso uma necessidade de correção e busca por um real desenvolvimento, pautado no aumento das oportunidades e liberdades, pois só assim é que se conseguirá trilhar um caminho com vistas a uma igualdade material. 
De acordo com o economista Amartya Sen (2010, p. 16), para que haja desenvolvimento é necessária a correção da ausência de liberdades ocasionada, por exemplo, pela pobreza e tirania, carência de oportunidades econômicas e destituição social sistemática. Essa lacuna de liberdades substantivas pode ser consequência de apenas uma ou de várias dessas fontes usurpadoras de liberdade.

Faz-se necessário o reequilíbrio, pois só homens e mulheres livres, dotados de oportunidades serão capazes de conquistar os bens necessários para uma vida digna e sustentável. Esse argumento decorre da constatação de que a desigualdade entre mulheres e homens afeta - e às vezes encerra prematuramente - a vida de milhões de mulheres e, de modos diferentes, restringe em altíssimo grau as liberdades substantivas para o sexo feminino. (SEN, 2010, p. 17).

Sabe-se que o econômico é necessário para ampliar as liberdades, bem como para conseguir efetivá-las, mas ele não pode ser a única mola propulsora do desenvolvimento, pelo contrário, o conceito mais moderno sobre o tema ressalta que o desenvolvimento sustentável não deve ser baseado apenas no crescimento econômico, mas a obedecer um imperativo ético da solidariedade com as gerações futuras, exigindo uma sustentabilidade social, ambiental e de viabilidade econômica, pois segundo Sachs (2008, p. 13-15), apenas as soluções que considerem esses três elementos é que merecem a denominação de desenvolvimento.

Segundo Celso Furtado (2008, p. 83), o desenvolvimento está relacionado ao conjunto de transformações que podem ocorrer nas estruturas sociais, acompanhadas da acumulação no sistema de produção. O desenvolvimento é um processo cultural e histórico, cuja dinâmica se apoia na inovação técnica posta a serviço de um sistema de dominação social.

Celso Furtado distingue crescimento econômico e desenvolvimento:

O crescimento econômico, tal qual o conhecemos, vem se fundando na preservação do privilégio das elites que satisfazem o seu afã de modernização; já o desenvolvimento se caracteriza pelo projeto social subjacente. Dispor de recursos para investir está longe de ser condição suficiente para preparar um melhor futuro para a massa da população. Mas quando o projeto social prioriza a efetiva melhoria das condições de vida da população, o crescimento se metamorfoseia em desenvolvimento (FURTADO, 2004, p.484).

Dentro deste cenário de que o direito ao econômico também se faz necessário para que se conquiste vários outros direitos fundamentais, Lucena (2012, p.80) menciona que os direitos fundamentais econômicos também devem ser amparados para a viabilização das liberdades, lembrando que não há como falar em liberdades sem estabelecer correlação com a igualdade, 
pois uma sociedade igualitária não sobrevive sem que seja baseada em seres humanos livres, detentores de suas escolhas, possuidores de capacidade de decisão sobre o caminho que querem perseguir, porque só assim os direitos fundamentais conseguirão ser efetivados.

Corroborando esse pensamento, Sen (1993, p. 318) ao tratar sobre as capacidades e a questão do bem-estar pessoal, reforça a ideia de que a capacidade reflete a liberdade pessoal de escolher entre vários modos de viver, tendo assim como termômetro de qualidade de vida a consequente capacidade de efetivar esse modo de viver escolhido por cada um.

Amartya Sen lembra que a busca pelo dinheiro, ou seja, pelo econômico, é fundamental para concretude de bens da vida, mas não se pode basear o alcance de uma vida digna na quantidade de mercadorias ou rendimentos, pois de acordo com Aristóteles, a riqueza não é efetivamente o que buscamos, é útil meramente na consecução de outros bens. Isso tudo pautado na ideia de que a avaliação do bem-estar de uma pessoa tem a ver com as efetivações elementares, que estão correlacionadas com os elementos constitutivos da vida, onde cada efetivação está ligada a uma conquista pessoal, derivando com isso um conceito mais amplo, o de capacidades, que é a combinação de efetivações que uma pessoa pode alcançar (SEN, 1993, p. 317).

A privação dessas liberdades acaba por afastar a possibilidade do alcance de uma vida com qualidade, já que se distancia dos mecanismos, ou seja, das capacidades que consigam concretizar os bens desejados, ou mesmo o mínimo social adequado a uma vida digna. Reforçase a necessidade de uma maior proteção das minorias e grupos vulneráveis, pois uma sociedade onde não há avanço social, que se perpetua dentro de um contexto de exclusão, gera um sentimento de acomodação resignada desse grupo sujeito à privação continua e à vulnerabilidade, alterando o sentido para eles do que seria prazer e auto-realização.

Isso acontece com as mulheres, que são vítimas de uma discriminação em diversos cenários, privadas muitas vezes de uma igualdade de acesso à educação, ao trabalho, à saúde, ao desenvolvimento profissional, ao comando de sua vida em todas as plataformas.

Portanto, a busca por um aumento de liberdades e de conquista de igualdade é o substrato dos direitos humanos, que, muito além de direitos positivos, integra um direito racional e crítico, sendo entendido como coisas desejáveis, fins que merecem ser perseguidos por qualquer tipo de sociedade. Bobbio reforça o entendimento ao afirmar que "a liberdade e a igualdade dos homens não são um dado de fato, mas um ideal a perseguir; não são uma existência, mas um valor; não são um ser, mas um dever ser.” (BOBBIO, 2004a, p. 15)

Para que o desenvolvimento seja de fato perseguido, a sociedade tem que trilhar o caminho da busca pelo aumento das liberdades, da efetivação da igualdade em sentido amplo, 
do respeito aos direitos humanos, isto é, por uma sociedade justa, onde se proteja a individualidade de cada ser, por sua inviolabilidade, e nem mesmo o bem-estar de toda a sociedade pode desconsiderar. Segundo Rawls (2016, p. 4) em uma "sociedade justa as liberdades da cidadania igual são consideradas irrevogáveis; os direitos garantidos pela justiça não estão sujeitos a negociações políticas nem ao cálculo de interesses sociais", sendo permitida apenas uma injustiça para evitar que haja outra ainda maior.

E sob o prisma de justiça pautada no respeito aos direitos humanos e perseguidora das liberdades, Bobbio (2004a, p. 44) ao mencionar a dificuldade de concretude dos direitos humanos por cada sociedade levanta a justificativa de ser um problema jurídico de amplitude política, não de uma mera filosofia, pois não se trata de saber quais são esses direitos, sua natureza ou fundamento, se são naturais ou históricos, absolutos ou relativos, mas sim qual o modo mais seguro para garantir e impedir que esses direitos, previstos em declarações tão solenes, sejam continuamente violados.

Um fator que deve ser somado na questão de gênero e a falta de oportunidades é a violência doméstica presente em toda sociedade mundial. De acordo com o Banco Interamericano de Desenvolvimento (BID), uma em cada cinco mulheres que faltam ao trabalho o faz por ter sofrido violência doméstica, o que agrava o processo de feminização da pobreza, na medida em que empobrece as mulheres e aumenta a dependência econômica, tornando-as mais vulneráveis, ocasionando um ciclo vicioso, onde a violação dos direitos civis gera a violação dos direitos sociais, bem como o contrário (PIOVESAN, 2004b, p. 8).

A violência lato sensu é um ato de brutalidade, abuso, constrangimento, desrespeito, descriminação, impedimento, imposição, invasão, ofensa, proibição, agressão física, psíquica, moral ou patrimonial contra alguém e caracteriza relações intersubjetivas e sociais definidas pela ofensa e intimidação pelo medo e horror. Já a violência doméstica, é uma espécie de violência que ocorre entre membros de uma mesma família, é extremamente delicada, de natureza complexa, pois fundamenta-se em relações interpessoais de desigualdade e de poder entre mulheres e homens ligados por vínculos consanguíneos, parentais, de afetividade ou de amizade.(CAVALCANTI, 2008, p.51)

Com base na busca pela igualdade, pela defesa das liberdades como peça fundante do desenvolvimento e do poder de decisão que cada ser humano deve possuir para assumir o comando da sua vida, e realizar o plano de vida delineado por cada um, faz-se necessário um estudo demonstrando como determinados grupos ainda possuem mais dificuldades de acesso às oportunidades bem como carência de capacidade de agente, especificamente o caso das 
mulheres, trazendo a importância do seu empoderamento, para que assim se tenha uma sociedade socialmente desenvolvida.

Enfim, é preciso lembrar que o desenvolvimento do Estado passa prioritariamente pelo desenvolvimento do homem, de seu cidadão, de seus direitos fundamentais. Sem ele, o mero avanço econômico pouco significará, apenas fará sentido para poucos.(Tavares, 2011, p.63)

\section{Desigualdade de gênero no cenário internacional}

A desigualdade de gênero é algo tão propagado, que alcança as mais diversas sociedades, independente do regime político, da localização geográfica, da religião, da cultura, e outros panoramas. Obviamente que o aspecto cultural é importante para o aumento ou diminuição desse tipo de desigualdade, é um dos fatores que mais influenciam a vulnerabilidade das mulheres, porém está longe de ser o único. Quanto mais situações de exclusões são adicionadas às mulheres, como serem negras, pobres, pertencerem a determinada religião ou contexto social, maior será a desigualdade e o preconceito enfrentando por elas, gerando assim um aumento da privação de liberdades.

Conforme Sen (2010, p. 29-30), a desigualdade sofrida pelas mulheres é fator, as vezes prematuro, de violação da vida de milhões de mulheres, em diversos modos, e restringe em altíssimo grau as liberdades substantivas para o sexo feminino. Como o assunto é caso de amplitude mundial, os organismos internacionais, dentre eles a Organização das Nações Unidas (ONU), prevê diversos documentos que reforçam a proteção da mulher nos mais diversos contextos sociais, como a liberdade sexual, a liberdade de expressão, o empoderamento da mulher como agente capaz de decidir sobre sua própria vida, assim como de influenciar no progresso da humanidade.

A importância do tema é tamanha que a igualdade de gênero é considerada como um dos dezessete objetivos do milênio, elencados pela ONU, com que se pretende alcançar essa igualdade de empoderamento de todas as mulheres e meninas. Tal atitude é de fato necessária para que se tenha um desenvolvimento econômico sustentável, pois como já previsto na Convenção Sobre a Eliminação de Todas as Formas de Discriminação contra a Mulher (1979), o estabelecimento da Nova Ordem Econômica Internacional baseada na equidade e na justiça contribuirá significativamente para a promoção da igualdade entre homens e mulheres. 
Quando se fala na busca por uma igualdade de gênero devem se levar em consideração as diferenças, pois não está se tratando de pessoas idênticas, mas dotadas de singularidades que as distinguem. Por isso a importância da busca por uma dimensão de igualdade material, ou seja, que vá além da justiça pautada no respeito à lei. Sobre o tema, a professora Piovesan (2004b, p.1) levanta o seguinte argumento:

\begin{abstract}
Neste cenário as mulheres devem ser vistas nas especificidades e peculiaridades de sua condição social. Ao lado do direito à igualdade, surge, como direito fundamental, $\mathrm{o}$ direito à diferença. Importa o respeito à diferença e à diversidade, o que lhes assegura um tratamento especial. $\mathrm{O}$ direito à diferença implica o direito ao reconhecimento de identidades próprias, o que propicia a incorporação da perspectiva de gênero, isto é, repensar, revisitar e reconceptualizar os direitos humanos a partir da relação entre os gêneros, como um tema transversal.
\end{abstract}

No âmbito internacional, cabe reportar os documentos que abordam a temática. $\mathrm{O}$ primeiro já mencionado é a Convenção sobre a eliminação de todas as formas de discriminação contra a mulher, aprovada em 1979, ratificada pelo Brasil em 1984. Esse documento tem grande importância, pois prevê uma dupla proteção, tanto no caráter repressivo-punitivo, proibindo todas as formas de discriminação, quanto no caráter positivo-promocional, voltado à promoção da igualdade (PIOVESAN, 2004b, p. 2)

Caminhando nesse contexto de documentos internacionais, a Declaração e Programa de Ação de Viena (1993) foi um marco na proteção dos direitos humanos das mulheres, pois possui um ponto específico sobre a "igualdade de condição e os direitos humanos das mulheres", reportando pontos importantíssimos como a questão da saúde, da violência, do afastamento das formas de discriminação decorrentes do sexo e preconceito cultural e extremismo religioso. Sobre a importância da Declaração de Viena, Piovesan (2004b, p. 5) faz a seguinte ponderação:

\footnotetext{
“(...) O legado de Viena: os direitos humanos das mulheres são parte inalienável, integral e indivisível dos direitos humanos universais. Não há direitos humanos sem a plena observância dos direitos das mulheres, ou seja, não há direitos humanos sem que metade da população mundial exerça, em igualdade de condições, os direitos mais fundamentais. Afinal, como lembra Amartya Sen, "nada atualmente é tão importante na economia política do desenvolvimento quanto o reconhecimento adequado da participação e da liderança política, econômica e social das mulheres. Esse é um aspecto crucial do desenvolvimento como liberdade"."
}

Outro documento é a Declaração sobre a Eliminação da Violência contra a Mulher, aprovada pela ONU, em 1993, bem como a Convenção Interamericana para Prevenir, Punir e Erradicar a Violência contra a Mulher, de 1994. Tais documentos reconhecem que a violência contra a mulher é uma afronta aos direitos humanos, limitadores da efetivação dos direitos 
fundamentais. De acordo com Piovesan (2004b, p. 2-3), a violência de gênero ocorre quando um ato é dirigido a uma mulher, por ela simplesmente ser mulher, ou quando atos afetam as mulheres de forma desproporcional.

Ainda sobre a questão de gênero, há uma grande conquista por parte das mulheres envolvendo a liberdade que está relacionada com a defesa dos direitos à sexualidade e à reprodução. Desde 1994, a Conferência do Cairo sobre População e Desenvolvimento, reconhece direitos reprodutivos como direitos humanos e estabelece princípios éticos relacionados ao tema, como o direito a ter controle sobre as questões relativas à sexualidade, à saúde sexual e à reprodutiva, assim como a decisão, livre de coerção, discriminação e violência, como um direito fundamental.

Apesar de todo arcabouço legislativo nacional e internacional que preza pela igualdade de gênero, e de ser considerado um dos compromissos firmados em 2015 na Assembleia Geral da ONU, que adotou a Agenda 2030 de Desenvolvimento Sustentável, as mulheres continuam sendo vítimas de desigualdades e de carência de liberdades.

Em 1995 ocorreu a Quarta Conferência Mundial das Mulheres, onde foi elaborado o documento denominado "Declaração e Plataforma de Ação de Berlim”, até então o plano mais progressivo de direitos das mulheres, elaborando uma plataforma de ação, estabelecendo compromissos sobre 12 áreas críticas de atuação. Essa Plataforma é baseada em um mundo em que cada mulher e cada menina pode exercer sua liberdade e escolhas e realizar todos os seus direitos, como por exemplo, viver livre da violência, ir à escola, participar da tomada de decisões e ganhar salários iguais para trabalhos iguais.

Todavia, de acordo com a ONU Mulheres (2017c), apesar do progresso dos últimos 20 anos, a plataforma continua inacabada, com mulheres ganhando menos que os homens, e com empregos de baixa qualidade. Dados alarmantes como o de que um terço das mulheres sofre violência física ou sexual em suas vidas; além disso, brechas nos direitos reprodutivos e na assistência médica são responsáveis pela morte diária de 800 mulheres durante o parto.

Ainda sobre a questão da discriminação de gênero no âmbito internacional, a ONU (2017a) divulgou que apenas 50\% das mulheres ao redor do mundo possuem emprego remunerado, todavia o salário dessas corresponde a 77\% do que é pago aos homens. Já na questão da saúde e reprodução, em todo mundo, três a cada cinco mulheres não têm acesso à licença maternidade. Retrata que, no Brasil, a cada cinco mães uma é adolescente, e de cada cinco, três nem trabalham nem estudam.

A questão da desigualdade entre homens e mulheres é ampliada nas situações de pobreza, fazendo com que o caminho ao desenvolvimento fique cada vez mais distante, pois o 
custo dessa desigualdade, elevada pelas questões de acesso à saúde e da garantia de direitos sexuais e reprodutivos, faz repercutir nos demais objetivos do milênio elencados pela ONU, como destacado no relatório "Mundos Distantes: Saúde e direitos reprodutivos em uma era de desigualdade”.

\begin{abstract}
Hoje, a desigualdade nos países não pode ser entendida apenas entre ter e não ter", afirma o representante do UNFPA no Brasil, Jaime Nadal. "As desigualdades são cada vez mais entendidas entre o que as pessoas conseguem e não conseguem fazer. As mulheres mais pobres, que não têm acesso a recursos que lhes permitam o planejamento reprodutivo ou que não conseguem ter bons atendimentos de saúde, são as que menos conseguem desenvolver seu potencial. (ONU, 2017a)
\end{abstract}

A fala de Jaime Nadal reforça a ideia de Amartya Sen de que o Desenvolvimento é consequência do aumento das liberdades, ou seja, não está relacionado exclusivamente com a quantidade de riquezas alcançadas pelas pessoas, mas sim pela capacidade de efetivação dos mínimos sociais, com acesso a recursos e oportunidades para o melhor planejamento de suas vidas.

Há de se ressaltar ainda que, de acordo com dados fornecidos pela ONU (2017a), na maioria dos países em desenvolvimento, as mulheres mais pobres têm menos opção de planejamento reprodutivo, menos acesso a atendimento pré-natal e são mais propensas a terem partos sem a assistência de um profissional de saúde. O acesso limitado ao planejamento reprodutivo leva a 89 milhões de gestações não intencionais e 48 milhões de abortos em países em desenvolvimento todos os anos.

A consequência disso não está apenas correlacionada com a saúde das mulheres, mas também com seu acesso ao mercado de trabalho remunerado, a uma independência financeira. Interligado, ainda está o fato da dificuldade de acesso a creches, o que limita ainda mais as mulheres na busca por emprego. E para aquelas que já o possuem, a ausência de licençamaternidade e a discriminação que muitas sofrem decorrente da maternidade, antes, durante a gestação e pós-parto, ocasiona uma determinada "penalidade pela maternidade", tolhendo assim a liberdade dessas mulheres, fazendo com que elas tenham que decidir sobre algo que teoricamente seria natural, entre avançar na carreira, continuar trabalhando ou se tornarem mães.

Apesar de a realidade ainda ser de desigualdade, existe um sistema Internacional que tenta avançar no sentido de uma igualdade material, seja por meio de documentos internacionais, que embora não sejam normas impositivas, trazem consigo valores e princípios éticos que devem ser racionalizados e perseguidos por toda a sociedade. Pois, só quando for ultrapassada a barreira do individualismo, e quando a racionalidade e a moral tornarem-se norte 
para as decisões particulares e públicas, voltadas para um sentimento de justiça, é que de fato haverá um progresso rumo ao desenvolvimento e paz social.

\section{A necessidade da condição de agente das mulheres para o desenvolvimento}

Como dito no inicio deste trabalho, é necessária a ampliação das liberdades, com o aumento das oportunidades e capacidades para que se chegue a um conceito de desenvolvimento. Diante disso, é indispensável o afastamento das privações e das desigualdades para que todos consigam ser agentes dos seus destinos e não jogados à loteria da sorte.

Como bem exposto por Lucena (2014, p. 78), a expansão das liberdades consiste na eliminação das privações, pois elas limitam as escolhas e oportunidades das pessoas de exercerem a sua condição de agente, porque é por meio desse protagonismo que surgem as chances de efetivação das habilidades, criando assim um cenário propício à realização do desenvolvimento de determinado povo.

Especificamente sobre a necessidade de condição de agente das mulheres, Amartya Sen inicia o discurso sobre o tema levantando o ponto de que a principio é necessária a remoção das iniquidades que restringem o bem-estar feminino.

Trabalhos empíricos recentes evidenciaram o modo como o respeito e a consideração pelo bem-estar das mulheres são acentuadamente influenciados por variáveis como o potencial das mulheres para auferir uma renda independente, encontrar emprego fora de casa, ter direitos de propriedade, ser alfabetizadas e participar como pessoas instruídas nas decisões dentro e fora da família. (SEN, 2010, p. 248-249)

O fortalecimento da voz ativa da mulher tem como um dos seus pilares a sua inserção no mercado de trabalho, pois faz com que as barreiras das desigualdades comecem a ser superadas, passando elas a possuir mais independência, ser mais respeitadas, e sua voz de comando dentro da família começa a ser compartilhada, corroborando também o aumento do grau de educação e reflexão, pelo fato de se inserir em outras relações sociais diferentes daquelas às quais era subordinada. A consequência disso é uma melhoria do seu bem-estar tanto dentro quanto fora de casa, trazendo prosperidade para a família e a sociedade.

Outro ponto de extrema importância levantado por Sen (2010, pg. 251) é que com a maior capacidade de agente das mulheres independentes, faz corrigir as iniquidades que 
arruínam a vida e o bem-estar das mulheres em comparação com a situação dos homens, pois por meio dessa condição ativa gerará a proteção de diversas vidas, inclusive as delas próprias.

Como dito, não é apenas a vida delas, mas de homens e crianças que estão em jogo, há provas consideráveis de que o ganho de poder das mulheres na família pode reduzir significativamente a mortalidade infantil, Sen (2010, p. 251). O autor ainda reforça que, além disso, esse empoderamento e voz ativa das mulheres, ampliados pela educação e o trabalho, podem influenciar a natureza da discussão pública sobre diversos temas sociais, incluindo a taxa de fecundidade aceitável, não apenas individualmente, mas também como prioridade para o meio ambiente.

A ideia trazida por Amartya Sen é de que a posição social em que a mulher se encontra, bem como o preconceito que sofre, decorrem de um contexto social e econômico, onde sua ascensão impõe respeito até no âmbito familiar, melhorando inclusive as distribuições no seio da família, quebrando os rótulos e impondo uma nova postura social. Mesmo quando a mulher acumula funções dentro e fora de casa, o fato de esta possuir uma renda faz com que passe a ter mais voz ativa, por depender menos dos outros, e assim a conquista de uma liberdade faz surgir outras, por exemplo a conquista de mais liberdade faz com que não sofra por fome, doença e privações.

Outro ponto é com relação à taxa de fecundidade. De acordo com Sen (2010, p. 253), há evidencias de que o aumento da capacidade de agente das mulheres faz com que tenha uma diminuição do número de filhos, concluindo que:

Os problemas gerais da superlotação ambiental — que podem afetar tanto as mulheres como os homens - vinculam-se estreitamente à liberdade específica das mulheres para não gerar e criar filhos constantemente, prática que arruína a vida de mulheres jovens em muitas sociedades do mundo em desenvolvimento.

Também existe outra correção com a fecundidade: é a alfabetização feminina, pois as mulheres mais instruídas tendem a gozar de mais liberdades para comandar suas vidas e tomar decisões familiares, inclusive no que se refere à fecundidade e à gestação de filhos.

Contextualizando a importância do tema com as políticas públicas adotadas, a ONU Mulheres (2017b) elenca “Os Princípios de Empoderamento das Mulheres” (WEPs, sigla em inglês), é um grupo de princípios para o meio empresarial que oferece orientação sobre como delegar poder às mulheres no ambiente de trabalho, mercado de trabalho e na comunidade. Ao todo são 7 princípios: estabelecer liderança corporativa sensível à igualdade de gênero, no mais alto nível; tratar todas as mulheres e homens de forma justa no trabalho, respeitando e apoiando 
os direitos humanos e a não-discriminação; garantir a saúde, segurança e bem-estar de todas as mulheres e homens que trabalham na empresa; promover educação, capacitação e desenvolvimento profissional para as mulheres; apoiar empreendedorismo de mulheres e promover políticas de empoderamento das mulheres através das cadeias de suprimentos e marketing; promover a igualdade de gênero através de iniciativas voltadas à comunidade e ao ativismo social; medir, documentar e publicar os progressos da empresa na promoção da igualdade de gênero.

Os Princípios de Empoderamento das Mulheres buscam apontar a melhor prática, trabalhando com a dimensão de gênero da responsabilidade, do Pacto Global da ONU e o papel do meio empresarial no desenvolvimento sustentável. Além de ser um guia útil para as empresas os Princípios procuram subsidiar outros stakeholders, incluindo os governos, em seu envolvimento com o meio empresarial. (ONU, 2017b)

Com base no lema de que a igualdade gera negócios, os "Princípios de Empoderamento das Mulheres", argumenta ser essencial o aumento da participação feminina para: a) construir economias fortes; b) estabelecer sociedades mais estáveis e justas; c) atingir os objetivos de desenvolvimento, sustentabilidade e direitos humanos intencionalmente reconhecidos; d) melhorar a qualidade de vida para as mulheres, homens, famílias e comunidades; e) impulsionar as operações e as metas dos negócios.

Tais princípios são importantíssimos, pois traçam um norte de como devem as políticas públicas ser conduzidas ou perseguidas, buscando sempre a mesma finalidade, que é a de promoção da igualdade entre homens e mulheres no local de trabalho, no mercado e na comunidade.

A análise desses princípios em conjunto das afirmações de Amartya Sen sobre a ideia de Desenvolvimento como Liberdade, elevando a capacidade de agente da mulher como fator de extrema relevância para o real desenvolvimento e as políticas públicas baseadas no aumento do poder de voz das mulheres, são fundamentos suficientes para confirmar que só haverá desenvolvimento sustentável quando as questões de desigualdade de gênero forem superadas, pois só com a participação feminina nas decisões sociais e particulares é que haverá progresso na humanidade.

Por fim, de acordo com Sen (2010, p. 263): 
O grande alcance da condição de agente das mulheres é uma das áreas mais negligenciadas nos estudos sobre o desenvolvimento e requer correção urgente. Podese dizer que nada atualmente é tão importante na economia política do desenvolvimento quanto um reconhecimento adequado da participação e da liderança política, econômica e social das mulheres. Esse é, de fato, um aspecto crucial do "desenvolvimento como liberdade".

\section{Considerações finais}

A efetivação dos direitos é uma das maiores dificuldades enfrentadas pelo mundo contemporâneo, diante da ausência de um sentimento comum altruísta e de se colocar no lugar do próximo, faz com que floresça cada vez mais uma sociedade individualista, com interesses particulares, distanciando-se do sentido de justiça. Além disso a crise econômica e as desigualdades sociais tão presentes nos diversos lugares do mundo são o retrato de que as políticas públicas não estão de fato comprometidas com a equidade e a erradicação da pobreza e marginalização, fazendo que os grupos vulneráveis, como as mulheres, careçam de oportunidades e voz ativa.

O estudo demonstrou que a desigualdade enfrentada pelas mulheres é um dos fatores que impede o alcance do desenvolvimento, necessitando por isso do aumento da capacidade ativa delas para que haja a superação de barreiras culturais e sociais e, por conseguinte sejam ultrapassados paradigmas.

Essa importância se faz tão necessária que a ONU e outros Organismos Internacionais, como a Organização Internacional do Trabalho (OIT), preveem programas e documentos que visam fortalecer a igualdade de gênero, com a finalidade de empoderar as mulheres, tornando-as protagonistas das suas próprias vidas, fazendo suas próprias escolhas sem que com isso se tornem vítimas de discriminação.

Um dos principais termômetros de que um país é desenvolvido se dá a partir do momento em que as desigualdades estão sendo minoradas, e a condição de agente das mulheres se faz necessária nesse momento, pois é quando de fato ocorrerá uma mudança exponencial na econômia e na sociedade, possuindo como uma das principais repercussões, dada por essa mudança de contexto, o caminho para efetividade do desenvolvimento humano, econômico e social. 


\section{Referências bibliográficas}

ARISTÓTELES, Ética a Nicômaco. Tradução de Torrieri Guimarães. São Paulo: Editora Martin Claret, 2015

BOBBIO, Noberto. A Era dos Direitos. Rio de Janeiro: Elsevier, 2004a.

CAVALCANTI, Stela Valéria Soares de Farias, Violência Doméstica: Análise artigo por artigo da Lei "Maria da Penha", no 11.340/06. Salvador: jus PODIVM, 2008

FURTADO, Celso. Os desafios da nova geração. Revista de Economia Política, v. 24, nº 4 (96), São Paulo, p. 483-486 out-dez, 2004.

LUCENA, Glauber. A Vertente Capacitária: Breve Reflexão da Inserção das Liberdades Instrumentais de Amartya Sem no Rol dos Direitos Humanos e a Relação com sua Teoria da Justiça. In Direito e Desenvolvimento: Revista do Curso de Direito. João Pessoa, vol. 5, n.9, pp.73-87, 2014.

ONU. Desigualdades ameaçam saúde e autonomia das mulheres, alerta fundo de população da ONU. Disponível em <https://nacoesunidas.org/desigualdades-ameacamsaude-e-autonomia-das-mulheres-alerta-fundo-de-populacao-da-onu/> . Acesso em 26 de outubro de 2017a.

ONU MULHERES. Princípio de Empoderamento das Mulheres. Disponível em $<$ http://www.onumulheres.org.br/referencias/principios-de-empoderamento-das-mulheres/>. Acesso em 26 de outubro de $2017 \mathrm{~b}$.

ONU MULHERES. Documentos de Referência. Disponível em $<$ http://www.onumulheres Acesso em 29 de outubro de 2017c..org.br/onu-mulheres/documentos-de-referencia/> . Acesso em 29 de outubro de $2017 \mathrm{c}$.

PIOVESAN, Flavia. Mulher e o debate sobre direitos humanos no Brasil. Revista de Doutrina da $4^{\mathrm{a}}$ Região, n. 2, 24 ago. 2004b. 
SACHS, Ignacy. Desenvolvimento Includente, Sustentável e Sustentado. Rio de Janeiro:

Ed. Garamond, 2008.

RAWLS, John. Uma Teoria da Justiça. São Paulo: Martins Fontes, 2016.

SEN, Amartya. Desenvolvimento como Liberdade. São Paulo: Companhia das Letras, 2010.

O desenvolvimento como expansão de Capacidades. Lua Nova [online]. n.28-29, pp.313-334. 1993.

TAVARES, André Ramos. Direito Constitucional Econômico. São Paulo: Método. 2011. 


\title{
A IMPLEMENTAÇÃO DO DIREITO FUNDAMENTAL À IDENTIDADE DE GÊNERO POR MEIO DE POLÍTICAS PÚBLICAS DE INCLUSÃO DOS TRANSGÊNEROS NO BRASIL
}

Fabrício Veiga Costa

Universidade de Itaúna - Professor permanente do PPGD

Denise Maria Soares

Universidade de Itaúna - Mestranda

\begin{abstract}
Resumo
O direito fundamental à identidade de gênero é reflexo da interpretação sistemática, inclusiva, democrática e extensiva do direito fundamental à igualdade material, liberdade de expressão, princípios da não-discriminação e dignidade humana. Os transgêneros rompem com o padrão de sexualidade imposto pela modernidade, transgridem o binarismo e, por isso, vivenciam a exclusão e marginalidade. A escolha do tema justifica-se na demonstração de que a implementação de políticas públicas é o meio de incluir e garantir dignidade aos transgêneros. Por meio da pesquisa bibliográfica e documental demonstrou-se a ineficiência do Estado em assegurar igualdade no exercício de direitos aos transgêneros.
\end{abstract}

Palavras-chave: Direito Fundamental à Identidade de Gênero, Trangêneros,Políticas Públicas,Inclusão, Igualdade Material.

\begin{abstract}
Resumen/Résumé
The fundamental right to gender identity is a reflection of the systematic, inclusive, democratic and extensive interpretation of the fundamental right to material equality, freedom of expression, principles of non-discrimination and human dignity. Transgenders break with the standard of sexuality imposed by modernity, transgress binarism and, therefore, experience exclusion and marginality. The choice of theme is justified by the demonstration that the implementation of public policies is the means to include and guarantee dignity for transgenders. Through bibliographical and documentary research, it was demonstrated the inefficiency of the State in ensuring equality in the exercise of rights to transgenders.
\end{abstract}


Keywords/Palabras-claves/Mots-clés:Fundamental Right to Gender Identity, Trangêneros, Public Policies, Inclusion, Material Equality.

\section{Introdução}

O objetivo geral da presente pesquisa é apresentar proposições científicas visando teorizar o direito fundamental à identidade de gênero, como reflexo da interpretação extensiva, sistemática, democrática e inclusiva dos direitos fundamentais à igualdade material, liberdade de expressão, princípios da não-discriminação e dignidade humana. Especificamentepretendese investigar a identidade de gênero, delimitando-se o objeto de análise no estudo dos transgêneros, considerados "transgressores" do padrão moderno de sexualidade imposto pelo binarismo.

Os transgêneros rompem com a dicotômica concepção de sexualidade imposta pela biologia, que categoriza pessoas em machos e fêmeas; masculinos e femininos. O sexo biológico diferencia-se da identidade de gênero, considerada uma construção psicossocial decorrente da subjetividade e liberdade do indivíduo em querer se construir e se desenhar a partir de seus desejos.

A partir dessas premissas iniciais, desenvolveu-se um estudo teórico visando analisar as políticas públicas no Estado Democrático de Direito, compreendendo-as como espaço de implementação dos direitos fundamentais expressamente previstos no plano constituinte. Por meio das políticas públicas o Estado deverá assegurar igualmente a todos os indivíduos o exercício dos direitos civis indispensáveis à própria condição humana. Omitir-se quanto a esse dever é legitimar a exclusão e a coisificação das pessoas.

A constatação do déficit no exercício de direitos fundamentais pelos trangêneros no Brasil ensejou a realização de uma pesquisa documental, no sentido de averiguar quais políticas públicas efetivamente foram propostas e implementadas em favor de travestis e transexuais. Verificou-se que o enfoque dessas politicas públicas funda-se na questão da utilização do nome social, como se esse fosse o único e principal direito e demanda reivindicados pelos trans. Outras demandas, como a problemática do uso do banheiro; criação de protocolos para regular a política pública de saúde dos transgênero; o exercício do direito fundamental à educação mediante o acesso e a permanência na escola; a baixa expectativa de vida de travestis e transexuais; a invisibilidade dos transgêneros no mercado de trabalho e sua presença maciça na economia informal são alguns exemplos da ineficiência estatal no que atine a uma política 
pública que assegura efetivamente a proteção das pessoas trans.

Nesse contexto, a delimitação do objeto da pesquisa ocorreu pontualmente na seguinte problematização: as políticas públicas implementadas pelo Brasil asseguram aos transgêneros o exercicio do direito fundamental à identidade de gênero? É juridicamente possível afirmar que o Brasil é ineficiente quanto ao planejamento e execução de políticas públicas direcionadas às pessoas trans?

Por meio da pesquisa bibliográfica e documental foi possível buscar fundamentos teóricos para debater criticamente a presente proposta temática, identificando aporias e despertando a curiosidade epistemológica no leitor em levantar novas indagações para outras investigações cientificas a serem realizadas. Por meio da escolha do método dedutivo foi possível especificar o foco de análise, partindo-se da teoria dos direitos fundamentais, demonstrando as proposições cientificas do direito fundamental à identidade de gênero para, assim, analisar se as politicas públicas brasileiras atuais são ou não hábeis a implementar o respectivo direito fundamental em favor dos transgêneros.

\section{Compreendendo o Direito Fundamental à Identidade de Gênero}

A identidade de gênero é uma construção psicossocial, diretamente vinculada a subjetividade dos indivíduos, que consiste em escolher livremente o modo como cada pessoa se identifica com seu gênero. "O conceito de gênero é compreendido como um divisor de águas para outra fase distinta da primeira onda do feminismo e anunciador, de certa forma, da valorização significativa do diferencialismo, da afirmação política das diferenças, dos processos identitários e de igualdades" (DIAS, 2015, p. 23). Dessa forma, "o conceito chama atenção para a diversidade ou as diferenças dentro da diferença (DIAS, 2015, p. 23).

Todo o debate proposto quanto ao estudo sofre a identidade de gênero relaciona-se com o fato de como a pessoa se sente e pretende ser reconhecida por outras pessoas, seja como homem ou mulher ${ }^{1}$. A construção da identidade de gênero "pode ser medida em diferentes graus de masculinidade ou feminilidade, sendo que estes podem mudar no decorrer da vida, de

\footnotetext{
${ }^{1}$ A MULHER? É MUITO SIMPLES, dizem os amadores de fórmulas simples: é uma matriz, um ovário; é uma fêmea, e esta palavra basta para defini-la. Na boca do homem o epíteto fêmea soa como um insulto; no entanto, ele não se envergonha da sua animalidade, sente-se, ao contrário, orgulhoso se dizem dele: "É um macho!". O termo fêmea é pejorativo, não porque enraíza a mulher na natureza, mas porque a confina no seu sexo. E se esse sexo parece ao homem desprezível e inimigo, mesmo nos bichos inocentes, é evidentemente por causa da inquieta hostilidade que a mulher suscita no homem; entretanto, ele quer encontrar na biologia uma justificação desse sentimento (BEAUVOIR, 2015, p. 37).
} 
acordo com alguns psicólogos" (BRASIL, Significado de Identidade de Gênero).

Historicamente sabe-se que "a partir do século XIX, o conceito de identidade de gênero ganhou ênfase e cresceu a preocupação em estabelecer novas normas de conduta e espaços específicos para o homem e para a mulher" (PINTO, 2015, p. 108). "O termo gênero se popularizou na década de 1990, mas começou a ser utilizado pela teoria social na década de 1970 como forma de propor novas maneiras de pensar as noções de feminino e masculino, além das explicações biológicas, e inserindo-as em relações sociais de poder" (LINS; MACHADO; ESCOURA, 2016, p. 25).

Para as ciências sociais e humanas, o conceito de gênero refere-se à construção social em torno do sexo anatômico. Ele foi criado para distinguir a dimensão biológica da dimensão social, baseando-se no raciocínio de que há machos e fêmeas na espécie humana”, embora “a maneira de ser homem e mulher é produzida na cultura". Nesse cenário, "as várias formas de fazer-se mulher ou homem são construídas socialmente, são produtos da realidade social e não são naturalmente determinados pelas diferenças inscritas nos corpos, assim também como no modo de viver desejos e prazeres corporais" (SEVERO, 2013, p. 62).

O presente estudo científico visa ressiginificar inicialmente o binarismo ${ }^{2}$ ediante a distinção teórica existente entre sexo e gênero. Na perspectiva proposta por Judith Butler, "a distinção entre sexo e gênero atende a tese de que, por mais que o sexo pareça irretratável em termos biológicos, o gênero é culturalmente construído: consequentemente, não é nem o resultado causal do sexo nem tampouco tão aparentemente fixo quanto o sexo" (BUTLER, 2015, p. 25-26).

A ruptura com a doutrina da heterossualidade vigorante, produto de padrões morais e religiosos impostos historicamente, constitui uma das principais pautas de abordagem crítica das pesquisas de gênero. "A heterossexualidade é uma posição política hegemônica imposta como fato natural, uma necessidade ontológica colocada como imprescindível à intelegibilidade dos corpos e condição prévia da identidade humana" (MELO, 2015, p. 233). Dessa forma, "em um sistema de legitimação que faz da essência humana a fonte da igualdade de direitos, o não-

\footnotetext{
${ }^{2} \mathrm{Na}$ ordem binária dos sexos, os indivíduos são, necessariamente, distribuídos em dois grupos: machos ou fêmeas. Os comportamentos esperados por essa "nomenclatura sexual" determinam as relações sociais de sexo, quer dizer, a referência, os protótipos de masculinidade e de feminilidade, construídos pelas sociedades e com base nos quais se mede o conjunto de comportamentos humanos. Para ilustrar essa ideia, Jessie Bernad9 associa certas características às mulheres: afetividade, passividade no amor, obediência, modéstia, pudor, amor ao lar, tendência monogâmica, gosto pela moda, cuidados com o bebê... Essa situação se encontra no universo profissional, no qual as mulheres ocupam, majoritariamente, os postos de secretárias, recepcionistas, babás, enfermeiras ou domésticas (BORRILLO, 2010, p. 292-293).
} 
reconhecimento dos direitos daqueles que fogem aos ditames da heterossexualidade faz pesar sobre eles uma suspeita sobre sua plena e inteira humanidade, e tende a associar à sua inferioridade social” (MELO, 2015, p. 233).

“A heterossexualização do desejo requer e institui a produção de posições discriminadas e assimétricas entre feminino e masculino, em que estes são compreendidos como atributos expressivos de macho e de fêmea" (BUTLER, 2015, p. 44). Classificar as pessoas mediante a criação de padrões normativos que regem as relações sociais e institucionais é uma forma de segregar e excluir aqueles indivíduos que não correspondem o padrão classificatório imposto. "Em nossa sociedade, devido à hegemonia branca, masculina, heterossexual e cristã, têm sido nomeados e nomeadas como diferentes aqueles e aquelas que não compartilham desses atributos" (LOURO, 2014, p. 54).

“Os primeiros esforços de teorização sobre o gênero versaram sobre a necessidade de diagnosticar as principais modalidades de sexismo operantes em sociedades contemporâneas" (LOPES, 2016, p. 21). Todos os esforços dos pesquisadores voltaram-se para demonstrar que dicotomizar a compreensão da identidade de gênero a partir da premissa biológica machofêmea ${ }^{3}$ era uma forma de excluir e marginalizar as pessoas, considerando-se que a escolhas livres e individuais na forma de ser eram ignoradas pelo padrão homogeneizante decorrente dos ideais da modernidade.

"Se o gênero são significados culturais assumidos pelo corpo sexuado, não se pode dizer que ele decorra de um sexo desta ou daquela maneira" (BUTLER, 2015, p. 26). Nesse contexto, "o gênero é concebido como construção social de papéis e desigualdades ancorada no sexo, compreendido como fato biológico (LOPES, 2016, p. 23).

A desconstrução das premissas biológico-evolucionistas utilizadas para classificar as pessoas entre machos e fêmeas se deu por meio de estudos filosóficos sobre a correlação existente entre o sexo e o gênero. $\mathrm{O}$ "gênero significa que homens e mulheres são produtos da realidade social e não naturalmente determinados pelas diferenças inscritas em seus corpos” (SEVERO, 2013, p. 36).

É nesse contexto teórico apresentado que se desenha a proposição do direito fundamental à identidade de gênero, corolário da igualdade material, princípio da nãodiscriminação, dignidade humana, cidadania e direito fundamental à liberdade de escolha. "A não inclusão na nova Carta constitucional da "orientação sexual" e da "identidade de gênero" entre as diversas situações de discriminação a serem combatidas pelos poderes públicos evidencia o quanto o contexto político daquele momento era desfavorável para o então chamado 
Movimento Homossexual Brasileiro" (CARRARA, 2010, p. 134).

Contrapondo-se o entendimento acima mencionado, verifica-se que o legislador constituinte, no artigo 3., inciso $\mathrm{IV}^{34}$, trouxe expressamente que um dos objetivos fundamentais da República Federativa do Brasil é "promover o bem de todos, sem preconceitos de origem, raça, sexo, cor, idade e quaisquer formas de discriminação" (BRASIL, Constituição da República Federativa do Brasil de 1988).

O disposto no parágrafo 2., do artigo 5. do texto constitucional prevê que "os direitos e garantias expressos nesta Constituição não excluem outros decorrentes do regime e dos princípios por ela adotados, ou dos tratados internacionais em que a República Federativa do Brasil seja parte". Na sequência do mesmo dispositivo constitucional, o parágrafo 3. institui que "os tratados e convenções internacionais sobre direitos humanos que forem aprovados em cada Casa do Congresso Nacional, em dois turnos, por dois quintos dos votos dos respectivos membros, serão equivalentes às emendas constitucionais".

As proposições constitucionais acima mencionadas fundamentam o princípio da nãodiscriminação, expressamente previsto no direito constitucional brasileiro vigente. "Efetivamente, o direito institui o princípio da não discriminação de sexos, tanto na esfera privada como na pública: a igualdade conjugal e a igualdade parental são quase perfeitas e a paridade é um objetivo constitucional” (BORRILLO, 2010, p. 295).

A declaração sobre a eliminação de todas as formas de intolerância e discriminação fundadas na religião ou nas convicções, da Assembleia Geral da Organização das Nações Unidas, de 25 de novembro de 1981; a Resolução número 2435, da Assembleia Geral da Organização dos Estados Americanos, de 3 de junho de 2008, que propõe a proteção dos direitos humanos, orientação sexual e identidade de gênero; a Declaração da Organização das Nações Unidas, do ano de 2008, aprovada por 66 países, da qual o Brasil é signatário, condena violações de direitos humanos com base na orientação sexual e na identidade de gênero

\footnotetext{
3 "Percebe-se aqui a plurivalência dos termos - masculino e feminino - que, ao mesmo tempo, definem primeiramente um organismo biológico (espermatozoides e óvulos), em segundo lugar, fornecem descrições sociológicas (observação do comportamento de indivíduos biologicamente machos e fêmeas) e, por último, dizem respeito a um sentido específico na psicanálise, de atividade e passividade ligados à libido, mas que se aproximam um tanto da definição biológica" (PORCHAT, 2014, p. 34).

${ }^{4}$ A proposição de defesa dessas minorias tem como um marco a Assembleia Nacional Constituinte de 1987-1988, que pretendeu colocar a proteção em razão de orientação sexual como um dos "Objetivos Fundamentais" da República Federativa do Brasil. A inclusão da proteção contra discriminação por orientação sexual ao dispositivo constitucional que, mais tarde, viria a estar prescrito no art. 3o, IV ("Art. 3o Constituem objetivos fundamentais da República Federativa do Brasil: ... IV - promover o bem de todos, sem preconceitos de origem, raça, sexo, cor, idade e quaisquer outras formas de discriminação"), esteve presente em pelo menos duas Comissões da Assembleia Nacional Constituinte (Comissão da Soberania e dos Direitos e Garantias do Homem e da Mulher e Comissão da Ordem Social) (BAHIA, 2010, p. 93).
} 
(BAHIA, 2010, p. 91-92) são fundamentos jurídicos encontrados nos tratados e convenções internacionais que estabelecem que a discriminação em razão da identidade de gênero constitui violação de direitos humanos.

Assegurar amplamente a proteção da pessoa humana contra qualquer tipo de discriminação em razão da sua identidade de gênero constitui uma forma de viabilizar o exercício da cidadania. Nesse sentido, Adilson José Moreira afirma que "a expressão cidadania sexual aqui formulada designa o postulado de interpretação da igualdade que aparece nos casos referentes a minorias sexuais' (MOREIRA, 2017, p. 15).

O exercício da cidadania, a partir das premissas trazidas pelo texto constitucional vigente, pressupõe a possibilidade de gozar de todos os direitos fundamentais previstos no plano constituinte, não se admitindo tratamento desigual em razão da orientação sexual ou identidade de gênero. "O debate atual sobre a inclusão social de minorias sexuais exemplifica a limitação dos métodos tradicionais de interpretação da igualdade, pois eles não são capazes de abarcar a complexidade posta pelas relações entre cidadania e sexualidade" (MOREIRA, 2017, p. 13).

A implementação de qualquer direito fundamental é reflexo da observância do princípio da igualdade material, que se efetiva quando os titulares desses direitos possuem iguais condições para o seu gozo e exercício. "Tendo em vista a importância dos direitos na autocompreensão dos indivíduos, a discussão sobre o tratamento igualitário de homens e mulheres homossexuais requer o reconhecimento do caráter político da sexualidade" (MOREIRA, 2017, p. 11).

"A luta pela igualdade entre os diferentes grupos sociais teve consequências relevantes, entre elas a formulação teórica de uma nova compreensão da isonomia: igualdade relacional" (MOREIRA, 2017, p. 9). Os movimentos sociais baseados nas questões de gênero e sexualidade tiveram fundamental reflexo no constitucionalismo contemporâneo, especialmente no que atine à igualdade no exercício de direitos pelos transgêneros.

Sabe-se que o direito é uma ferramenta importante na luta pela inclusão e superação da marginalidade e discriminação em razão de questões de gênero, embora a implementação de tais direitos constitui uma luta constante dos movimentos sociais e da sociedade como um todo. "A sexualização do sujeito pelo direito continua a ser um ato de produção de desigualdades ocultas pelo caráter natural da atribuição dos gêneros, tanto pelo estabelecimento do estado das pessoas, como também pelo acesso ao direito ao casamento e à filiação (BORRILLO, 2010, p.297).

A igualdade relacional é uma construção conceitual fundada em práticas sociais responsáveis, voltadas à transformação das relações de poder assimétricas existentes em 
diferentes classes de pessoas. "Essa forma de igualitarismo parte do pressuposto de que a igualdade é um valor que deve guiar as relações entre os cidadãos e cidadãs, sendo que elas podem ser mais ou menos igualitárias, tendo em vista a forma como diferentes segmentos sociais são vistos dentro da sociedade" (MOREIRA, 2017, p. 9).

O exercício do direito de liberdade de escolha, conferido a cada indivíduo de poder construir sua identidade, constitui fundamento para o reconhecimento da identidade de gênero enquanto direito fundamental. A relevância da temática em tela decorre da exclusão, invisibilidade e marginalidade vivenciada pelos transgêneros, no Brasil, "alvos de preconceito, desatendimento de direitos fundamentais, [...] exclusão estrutural (acesso dificultado ou impedido à educação, ao mercado de trabalho qualificado e até mesmo ao uso de banheiro) e de violências variadas" (JESUS, 2012, p. 2).

Mesmo sabendo-se que a liberdade de escolha e a igualdade material são direitos fundamentais conferidos indistintamente a todos os indivíduos, corolário do exercício da cidadania, sabe-se que o próprio sistema jurídico ainda possui antinomias quando estabelece que "os registros civis brasileiros não adotam o conceito de gênero, ainda se restringindo ao sexo biológico, percepções estereotipadas negativas e de atos discriminatórios contra homens e mulheres transexuais e travestis" (JESUS, 2012, p. 2).

Se a própria legislação brasileira ainda segue o binarismo e os padrões impostos pela doutrina da heterossexualidade, fica evidente a exclusão dos transgêneros pelo próprio direito vigente. A proposição teórica do direito fundamental à identidade de gênero visa construir critérios de interpretação do direito fundados na dignidade humana, liberdade de escolha, vedação de atos discriminatórios e igualdade material, essenciais à descoisificação dos transgêneros, necessários a sua visibilidade e inclusão como legítimos titulares dos direitos fundamentais previstos na ordem constitucional vigente.

\section{Desmitificando os transgêneros para além do binarismo ${ }^{5}$}

A compreensão da identidade de gênero, como fundamento central ao entendimento

\footnotetext{
${ }^{5} \mathrm{O}$ binarismo pressupõe a concepção segundo a qual a definição do sexo é apresentada como realidade verdadeira já existente sobre a qual se constroem os gêneros. A identidade sexual é concebida como algo natural, que atribui consistência objetiva e científica à teoria dos dois sexos, de tal modo que a Medicina e a Biologia se evidenciam como campos de reflexão que não apenas definem os sexos, mas também estabelecem quantos existem. Essa concepção "[...] supõe uma fundamentação naturalizada da crença de que há dois sexos e somente dois, inexistindo outras possibilidades” (BUNCHAFT; CRISTIANETTI, 2016, p. 70).
} 
sobre os transgêneros, condiciona-se ao estudo crítico do modelo de sexualidade proposto e instituído pela modernidade, que objetivou estabelecer padrões fundados na dicotômica assertiva do machoxfêmea; masculinoxfeminino. Outras formas de exercício e construção da sexualidade e da identidade de gênero foram ignoradas pelos estudiosos, causando a exclusão, invisibilidade, coisificação e marginalidade daqueles (transgêneros) que não se enquadravam no molde previamente estabelecido.

"O sistema sexual ocidental, assim como a maioria dos sistemas no resto do mundo, apenas admite dois sexos, sendo isso aceito como verdade dogmática e reproduzido pela maioria das pessoas" (SANTOS, 2013, p. 4) As premissas teóricas preconizadas pelo binarismo ignora a existência das múltiplas identidades de gênero que poderão ser construídas a partir da liberdade de escolha conferida a cada indivíduo. "Uma hospitalidade incondicional no âmbito de uma organização socioessexual binária é absolutamente impossível, uma vez que tal binarismo só existe na medida em que é moldado a partir da multiplicidade nunca acolhida como tal" (SANTOS, 2013, p. 17).

"A segunda característica do binarismo diz respeito ao caráter dicotômico da concepção de sexo. De um lado, o sexo masculino que se contrapõe ao sexo feminino, configurando-se como dois polos diferenciados entre si. Se não se é uma coisa (homem), inevitavelmente se é outra (mulher)" (BUNCHAFT; CRISTIANETTI, 2016, p. 70). "As representações de gênero e sexualidade oriundas deste binarismo masculino/feminino fazem com que qualquer sexualidade desviante da norma heterossexual seja vista como desvio e até mesmo passível de cura em alguns casos" (SILVEIRA, 2015, p. 157).

Avançar no debate crítico é transcender "os limites do binarismo fundado no processo de asssignação sexual pela aparência dos órgãos genitais que acompanha (e, algumas vezes, precede) o nascimento" (ALMEIDA, 2012, p. 514). A imposição da doutrina da heteronormatividade, fundada no binarismo, é responsável pela marginalização dos transgêneros, considerando-se que "é possível afirmar que essas pessoas (quase que universalmente) enfrentam dificuldades em função da predominância do binarismo de gênero e da matriz heterossexual na maioria das culturas" (ALMEIDA, 2012, p. 515).

Manter os estudos de gênero e sexualidade fundados na concepção binária é legitimar o aprisionamento dos transgêneros, impedindo-os de serem reconhecidos por instituições (públicas e privadas), pela sociedade, pelo Direito. Esse é uma das maneiras de tratá-los desigualmente, ignorando-se a multiplicidade de formas como as pessoas podem construir sua identidade. "O modelo do binarismo sexual é apenas um entre outros possíveis para a compreensão das formas de subjetivação atuais, complexas e diversas. Novas teorias, ideias e 
reflexões são possíveis, e necessárias” (POMBO, 2017, p. 389).

Romper com o binarismo é superar a concepção taxonômica de ciência; é abandonar o critério classificatório de condutas humanas a partir da sexualidade; é reconhecer que a subjetividade do indivíduo o legitima a construir sua sexualidade e identidade de gênero a partir de seus desejos, não cabendo à ciência limitá-lo nessas escolhas. Nesse sentido,

As reivindicações por justiça em uma sociedade pluralista relativas à crítica ao binarismo devem supor o insight crítico-reflexivo da norma da paridade de participação por meio da qual torna-se possível avaliar quais demandas por reconhecimento são efetivamente legítimas, confrontando-se estruturas de poder heteronormativas (BUNCHAFT; CRISTIANETTI, 2016, p. 72).

"Se levarmos em consideração o binarismo masculino/feminino podemos dizer que há identidades e subjetivações que o ultrapassam e hibridizam características "esperadas" para determinado gênero e naturalizadas no âmbito social” (SILVEIRA, 2015, p. 168).

Transgênero é uma nomenclatura que engloba os travestis, os transformistas, transexuais, drag queens, cross-dressers, esclarecendo-se que "qualquer desses grupos pode ser homossexual, como heterossexual, como bissexual" (VENCATO, 2003, p. 195), fato esse que evidencia a distinção teórica existente entre orientação sexual e identidade de gênero ${ }^{6}$.

O cotidiano da população transgênera no Brasil é marcado pelo preconceito, violação de "direitos fundamentais (diferentes organizações não lhes permitem utilizar seus nomes sociais e elas não conseguem adequar seus registros civis na justiça), exclusão estrutural (acesso dificultado ou impedido à educação, ao mercado de trabalho qualificado e até mesmo ao uso de banheiros)", além dos diversos casos de violência decorrentes de "ameaças, agressões, homicídios, o que configura a extensa série de percepções estereotipadas negativas e de atos discriminatórios contra homens e mulheres transexuais e travestis denominada - transfobia" (JESUS, 2014, p. 105-106).

Sob o ponto de vista psicanalítico, “os transtornos da identidade sexual de gênero levaram a princípio a rubrica da nosografia psiquiátrica do começo do século 20 , segundo um

\footnotetext{
${ }^{6}$ Identidade de gênero é o gênero com o qual uma pessoa se identifica, que pode ou não concordar com o gênero que lhe foi atribuído quando de seu nascimento, ou seja, uma pessoa pode nascer com um sexo biológico (homem ou mulher) e se identificar com o gênero oposto (masculino ou feminino). Orientação sexual é atração afetivosexual por alguém, vivência interna relativa à sexualidade (heterossexual, homossexual ou bissexual). Identidade de gênero e orientação sexual são dimensões diferentes, que não devem ser confundidas. O papel de gênero é o modo de agir em determinadas situações conforme o gênero atribuído, ensinado às pessoas desde o nascimento; é de cunho social e não biológico (SILVA; BEZERRA; QUEIROZ, 2015, p. 365).
} 
critério prevalentemente descritivo e fenomenológico", ou seja, tanto o travestismo quanto o transexualismo "foram de qualquer modo colocadas firmemente na categoria das perversões" (ARGENTIERI, 2009). A classificação patológica dessas manifestações de gênero deixa claro que considerar os transgêneros como doentes era uma forma de dizer que os mesmos destoavam do critério classificatório imposto pelo binarismo.

O estudo da teoria Queer demonstra que "as pessoas que fogem ao padrão heteronormativo não são intelegíveis para os padrões hegemônicos de gênero fundamentados no binarismo e se tornam alvo de preconceito e/ou discriminação em função da sua identidade de gênero, prática esta denominada de transfobia" (SILVA; BEZERRA; QUEIROZ, 2015, p. 366). Partindo-se da pressuposição lógica de que o corpo "é um atributo natural e que define a identidade de homens e mulheres enquanto pessoas de um sexo ou de outro, as mudanças corporais realizadas pelas travestis e transexuais implicam em dificuldade de convivência nos espaços sociais" (SILVA; BEZERRA; QUEIROZ, 2015, p. 366).

A justificativa da escolha do tema em tela, qual seja, a efetivação do direito fundamental à identidade de gênero por meio de políticas públicas de inclusão dos transgêneros no Brasil, decorre de sua relevância prática e teórica. O cotidiano de exclusão e violência vivenciados pelos transgêneros explica a necessidade de teorização jurídica do respectivo direito fundamental, como forma de resistência e efetivação dos princípios da dignidade humana, igualdade material, não-discriminação e o direito fundamental de liberdade de escolha. A compreensão do conceito de políticas públicas, no contexto da constitucionalidade democrática, faz-se necessária ao debate da inclusão dos transgêneros por meio do gozo e exercício dos direitos fundamentais expressamente previstos no plano constituinte.

\section{Políticas públicas, inclusão e democracia}

A instituição do Estado Democrático de Direito, pelo legislador da Constituição brasileira de 1988, materializa a premissa de que esse paradigma de Estado tem como objetivo a implementação dos direitos fundamentais, corolário do exercício da cidadania e observância da dignidade humana. "Os direitos fundamentais, como resultado da personalização e positivação constitucional de determinados valores básicos [...], integram, ao lado dos princípios estruturais e organizacionais [...], o núcleo substancial formado pelas decisões fundamentais", ressaltando-se que no modelo democrático é imprescindível “certas vinculações de cunho material para fazer frente aos espectros da ditadura e do totalitarismo" (SARLET, 2004, p. 70). 
Nas sociedades democráticas tem-se a "expectativa de que a escala ou o âmbito no qual se processam as decisões políticas viabilizem a realização de determinados conteúdos do ideal democrático" (ARRETCHE, 1996).

As proposições legislativas trazidas pelo texto constitucional vigente objetivam assegurar a ampla proteção da pessoa humana, a inclusão e visibilidade dos sujeitos marginalizados, mediante a interpretação extensivo-sistemática dos direitos fundamentais. “A já apontada não-exaustividade [...] do Catálogo de direitos fundamentais resulta inequivocamente [...] da circunstância de que o artigo 5., parágrafo 2., da CF, encerra uma autêntica norma geral inclusiva, impondo [...] uma interpretação sintonizada [...] com a Declaração Universal dos Direitos do Homem” (SARLET, 2004, p. 96).

$\mathrm{O}$ eixo que rege a ordem constitucional brasileira vigente é a interpretação e aplicabilidade ampla dos direitos fundamentais como condição de exercício da cidadania no contexto da igualdade material, liberdade e dignidade humana. "A fundamentalidade material, por sua vez, decorre da circunstância de serem os direitos fundamentais elemento constitutivo da Constituição material, contendo decisões fundamentais sobre a estrutura básica do Estado e da Sociedade" (SARLET, 2004, p. 87).

A instituição de políticas públicas visa assegurar o igual exercício dos direitos fundamentais previstos no plano constituinte, indistintamente a todos os cidadãos. "No plano democrático constitucionalizado, as políticas públicas aparecem como exigências do cidadão à efetivação dos direitos fundamentalizados constitucionalmente, não como mera medida isolada praticada pelo Estado com o desiderato de dar efetividade aos direitos fundamentais" (PENNA, 2011, p. 211-212).

O estudo das proposições teóricas sobre política pública “designa aquela espécie de padrão de conduta que assinala uma meta a alcançar, geralmente uma melhoria em alguma característica econômica, política ou social da comunidade, ainda que certas metas sejam negativas, pelo fato de implicarem que determinada característica deve ser protegida contra uma mudança hostil” (BUCCI, 2006, p. 253).

Considerando-se que "as políticas públicas são indispensáveis para a garantia e a promoção de direitos fundamentais" (MOREIRA, 2012, p. 165), verifica-se que sua implementação, na perspectiva democrática, condiciona-se à interpretação extensiva, inclusiva e sistemática dos respectivos direitos, já que "os direitos fundamentais não podem ser restringidos, devendo o intérprete aplicá-los da forma mais abrangente possível” (MOREIRA; FERNANDES; RIBEIRO, 2012, p. 131). 
Implementar direitos fundamentais numa sociedade democrática exige que o pluralismo e a diversidade sejam observados. Especificamente no contexto do objeto da presente pesquisa, tais direitos devem ser vistos como o fundamento constitucional hábil a assegurar a ampla proteção jurídica dos transgêneros, legitimando-os, através de políticas públicas inclusivas, a exercerem os direitos fundamentais expressamente previstos no plano constitucional.

“Em um Estado Democrático, a definição do conteúdo e dos limites dos direitos fundamentais é primariamente uma competência institucional dos órgãos parlamentares e se sujeita ao fato do pluralismo e às circunstâncias da política” (MELLO, 2004, p.159).

Quando o Estado nega o exercício dos direitos fundamentais legitima a exclusão do sujeito, o coisifica, retirando-lhe a possibilidade de uma vida digna. "Os direitos fundamentais representam a constitucionalização daqueles direitos humanos que gozaram de alto grau de justificação ao longo da história dos discursos morais, que são, por isso, reconhecidos como condições para a construção e o exercício dos demais direitos" (GALUPPO, 2003, p. 233).

"O conceito de Estado democrático de direito pressupõe a pré-compreensão do conceito de direito fundamental como categoria básica do modelo de Estado constitucional ocidental" (SOARES, 2000, p. 111). É nesse paradigma de Estado que a inclusão dos marginalizados e invisíveis socialmente (transgêneros) torna-se juridicamente possível, através do exercício daqueles direitos fundamentais essenciais à condição humana, hábeis a romper com o dogma da modernidade, centrado no binarismo e na perspectiva taxonômica de compreensão da sexualidade e da identidade de gênero.

\subsection{Políticas públicas de inclusão dos transgêneros no Brasil}

Considera-se política pública de inclusão de transgêneros toda iniciativa estatal no sentido de assegurar visibilidade, inclusão, igualdade material e dignidade humana. São medidas estatais instituídas no sentido de permitir o igual exercício dos direitos civis aos transgêneros, possibilitando-lhes condições dignas o suficiente para deixarem a marginalidade imposta por padrões morais e religiosos que não os reconhecem com iguais aos demais.

O objetivo específico do trabalho de investigação científica é apresentar quais medidas os entes federativos brasileiros têm adotado no sentido de assegurar a proteção jurídicoconstitucional dos transgêneros, evidenciando que ainda existe um longo caminho a percorrer. Em 05 de novembro de 2001, a Assembleia Legislativa do Estado de São Paulo, aprovou a Lei 10.948, de autoria do deputado Renato Simões. Tal dispositivo legal prevê punição para 
toda manifestação atentatória ou discriminatória praticada contra cidadão homossexual, bissexual ou transgênero. Considera-se ato atentatório ou discriminatório em razão do gênero a prática de ações violentas, constrangedoras, intimidatórias ou vexatórias; proibição de ingresso ou permanência em estabelecimento público ou privado; preterir, sobretaxar ou impedir locação, compra, aquisição ou empréstimo; praticar o empregador ou seu preposto demissão em função da orientação sexual do empregado; proibir a livre expressão ou manifestação de afetividade. A prática dos atos discriminatórios acarretará a instauração de processo administrativo, por reclamação do ofendido ou de ofício pela autoridade competente. Dentre as penalidades admissíveis, ressalta-se a advertência, multa, suspensão ou cassação da licença estadual para funcionamento (BRASIL, Lei 10.948).

O Decreto número 51.180, de 14 de janeiro de 2010, do município de São Paulo, dispõe sobre a inclusão e uso do nome social de pessoas travestis e transexuais nos registros municipais, determinando que o nome social pode ser utilizado em fichas de cadastros, formulários, prontuários e outros documentos. Deve-se resguardar a proteção jurídica donome social pelo qual travestis e transexuais, ou seja, como são identificados socialmente, ressaltando-se a necessidade de requerimento expresso. O nome social deverá ser escrito entre parênteses, antes do respectivo nome civil, de modo a evitar, no trato social, a utilização do respectivo nome civil na confecção de crachás, carteiras ou outros tipos de identificação (BRASIL, Decreto 51.180).

O Decreto número 55.588, de 17 de março de 2010, editado pelo então governador do Estado de São Paulo José Serra, dispõe sobre o tratamento nominal das pessoas transexuais e travestis nos órgãos públicos do respectivo ente federativo (BRASIL, Decretto 55.588).

O Decreto 8737 , de 29 de abril de 2016, editado pela então presidente da república Dilma Rousseff, dispõe sobre o uso do nome social e o reconhecimento da identidade de gênero de pessoas travestis e transexuais no âmbito da administração pública federal direta, autárquica e fundacional. $\mathrm{O}$ artigo 2., do respectivo diploma normativo, estabelece que órgãos eentidades da administração pública federal, em seus atos e procedimentos, deverão adotar o nome social da pessoa travesti ou transexual, de acordo com seu requerimento. Nos registros dos sistemas de informação da administração pública federal deverão conter o nome social em destaque, acompanhado do nome civil, utilizado apenas para fins administrativos internos. A utilização do nome civil dos travestis ou transexuais, acompanhado do nome social, somente ocorrerá quando estritamente necessário ao interesse público ou para salvaguardar direitos de terceiros (BRASIL, Decreto 8.727/2016). 
Em 22 de dezembro de 2016, o prefeito do município de São Paulo, Fernando Haddad, editou o Decreto 57.559, que dispõe sobre o uso do nome social e o reconhecimento da identidade de gênero de travestis, mulheres transexuais e homens trans no âmbito da administração pública direta e indireta. Os órgãos da administração pública municipal devem, a pedido da pessoa, adotar e utilizar o nome social em todos os registros e sistemas de informação, tais como cadastro, formulários, prontuários, crachás e documentos. $\mathrm{O}$ uso da identidade civil limita-se aos sistemas internos e de acesso restrito, garantindo-se o destaque público do uso do nome social. Nos casos de publicação de procedimentos no Diário Oficial da Cidade o nome civil dever ser substituído por número de documento oficial, acompanhado do respectivo nome social (BRASIL, Decreto 57.559).

A recente Portaria 33, de 17 de janeiro de 2018, do Ministério da Educação e Cultura, editada pelo Ministro da Educação, Mendonça Filho, define o uso do nome social de travestis e transexuais nos registros escolares da educação básica no Brasil, para alunos maiores de 18 anos. Os alunos menores de 18 anos poderão solicitar o uso do nome social durante a matrícula ou a qualquer momento, desde que haja pedido expresso dos pais ou representantes legais. Tal portaria entrou em vigor na data de sua publicação (BRASIL, Portaria 33). Ressalta-se que o objetivo da norma jurídica em tela é minimizar as estatísticas de violência de gênero e bullying ocorridos na escola em razão de preconceitos, discriminações, exclusão e marginalidade vivenciada cotidianamente pelos transgêneros no Brasil.

A Lei 11.488, de 19 de janeiro de 2017, dispõe sobre a reorganização da estrutura administrativa da prefeitura municipal de Sorocaba, município do estado de São Paulo. Em seu artigo 18 estabelece que compete à Secretaria da Igualdade e Assistência Social, além das atribuições genéricas às demais secretarias, planejar e executar atividades de apoio às ações sociais do município, promovendo o bem-estar através de programas direcionados aos transgêneros (BRASIL, Lei 11.488).

No ano de 2013 o Ministério da Saúde instituiu a política nacional de saúde integral de lésbicas, gays, bissexuais, travestis e transexuais, embora ressalte a ausência de normas e protocolos específicos de atendimento à saúde de travestis e transexuais.

Mesmo demonstrando-se a existência de leis, decretos e outros instrumentos normativos voltados à proteção dos transgêneros no Brasil, verifica-se que tais políticas públicas ainda são incipientes, considerando-se que ainda se limitam ao debate do uso no nome social.

Outras inúmeras demandas integram a pauta dos transgêneros. A problemática e o desafio referente ao uso do banheiro é um tema ainda muito pouco discutido pelas instituições 
e pela sociedade em razão do preconceito existente. A ausência de uma política pública especificamente efetiva e direcionada à saúde de travestis e transexuais demonstra ao descaso do Estado em abordar e enfrentar pontualmente as questões que permeiam o universo trans. $\mathrm{O}$ baixo número de travestis e transexuais nas escolas e universidades, e sua alta concentração no trabalho informal e nas zonas de prostituição é mais uma clara constatação da exclusão e da ineficiência das políticas públicas no Brasil.

O acesso à educação e a permanência na escola são desafios quotidianamente vivenciados, considerando-se que o espaço escolar acaba reproduzindo a violência sofrida na sociedade. Considerando-se o baixo nível de formação escolar, a população trans enfrenta dificuldade de inserção no mercado de trabalho, não alcançando um posto de trabalho com vínculo formal de emprego. Tal situação enseja, consequentemente, ofensa a outro direito fundamental, qual seja, a previdência social, especificamente a aposentadoria e demais benefícios previdenciários. Outra questão importante a ser ressaltada é a baixa expectativa de vida dos transgêneros em razão dos mais diversos tipos de violência sofridos.

A constatação da ineficiência das politicas públicas direcionadas aos transgêneros demonstra a ausência de prioridade do Estado quanto ao tema. A consequência desse cenário é a exclusão, marginalidade e invisibilidade legitimados pelo próprio Estado, que juntamente com a sociedade e demais instituições negam direitos e retiram a condição humana desses sujeitos, tornando-os “coisas" que destoam do padrão moral e cientificamente imposto pela modernidade.

\section{Conclusão}

Os transgêneros são pessoas que transgridem e rompem com o padrão imposto pela modernidade, fundado em proposições que dicotomizam a sexualidade humana em machos e fêmeas; masculino e feminino. Travestis e transexuais são manifestações simbólicas do quanto o binarismo limita o exercício da sexualidade, inviabilizando a construção da identidade de gênero. Enquanto o sexo é definido anatomicamente pelo pênis e pela vagina, a identidade de gênero é uma construção psicossocial decorrente da subjetividade, liberdade e desejos dos indivíduos, podendo ser desenhado e redesenhado ao longo da vida.

A teorização do direito fundamental à identidade de gênero busca assegurar visibilidade jurídico-constitucional aos transgêneros, conferindo-lhes fundamentos para resistir à violência, exclusão, marginalidade e invisibilidade impostos pela sociedade, Estado 
e instituições fundadas em padrões morais, religiosos e que reproduzem o dogma da heteronormatividade, como meio de coisificar as pessoas trans.

$O$ direito fundamental à identidade de gênero é reflexo da interpretação constitucionalizada, democrática, inclusiva, sistemática e extensiva dos direitos fundamentais à igualdade material, liberdade de escolha, princípios da não-discriminação e dignidade humana. Trata-se de direito corolário da cidadania; imprescindível à resistência pela inclusão.

Numa sociedade democrática, os direitos fundamentais previstos no plano constituinte devem ser igualmente acessíveis a todas as pessoas. O Estado, por meio de políticas públicas inclusivas, tem que planejar e executar os meios de acesso e gozo de tais direitos. Negar direitos fundamentais por meio da ausência ou ineficiência de políticas públicas é uma forma encontrada pelo Estado para excluir, marginalizar, coisificar e estigmatizar pessoas.

O Brasil, especialmente a partir da última década, iniciou um tímido movimento no que atine à criação de politicas públicas voltadas aos transgêneros. Algumas leis e decretos foram editados especialmente para assegurar o uso do nome social e problematizar a questão da discriminação e do preconceito. Porém, inúmeras outras demandas das pessoas trans são ignoradas pelo Estado, o que evidencia sua ineficiência, descaso e desinteresse em assumir a luta pela inclusão dos transgêneros.

A ausência de regulamentação jurídico-legal quanto ao uso do banheiro; a inexistência de protocolos específicos de atendimento dos transgêneros no Sistema Único de Saúde; a proibição velada de doação de sangue; os números de evasão e fracasso escolar, além da dificuldade de acesso e permanência dos transgêneros na escola e nas universidades; a baixa formação escolar que dificulta o acesso ao mercado formal de trabalho; a presença intensa dos transgêneros na informalidade e nas zonas de prostituição; a violação do direito fundamental a previdência social em razão da ausência de um emprego formal; a baixa expectativa de vida decorrente da violência (moral, física, psicológica e sexual) e exclusão, são alguns exemplos que evidenciam a ineficiência do Estado brasileiro em planejar e executar politicas públicas especificas que assegurem a plena proteção jurídica das pessoas trans.

A negligência estatal quanto às políticas públicas voltadas aos transgêneros desencadeia a violação e não implementação do direito fundamental à identidade de gênero, uma vez que ratifica a discriminação, desigualdade, coisificação das pessoas trans e sua absoluta exclusão reproduzida historicamente em razão de não se enquadrarem no engessado modelo moderno de sexualidade binária. 


\section{Referências bibliográficas}

ALMEIDA, Guilherme. Homens Trans: novos matizes na aquarela das masculinidades? Estudos Feministas, Florianópolis, 20(2): 256, mai-ago., 2012, p. 513-523. Disponível em http://www.scielo.br/pdf/ref/v20n2/v20n2a12. Acesso em 29 jan. 2018.

ARGENTIERI, Simona. Travestismo, transexualismo, trangêneros: identificação e imitação. Jornal de Psicanálise, v. 42, n. 77, São Paulo, dez., 2009. Disponível em http://pepsic.bvsalud.org/scielo.php?script=sci_arttext\&pid=S0103-58352009000200012. Acesso em 30 jan. 2018.

ARRETCHE, Marta. MITOS DA DESCENTRALIZAÇÃO - mais democracia e eficiência nas políticas públicas?, 1996. Disponível em http://www.anpocs.org.br/portal/publicacoes/rbcs_00_31/rbcs31_03.htm. Acesso em 30 jan. 2018.

BAHIA, Alexandre Gustavo Melo Franco. A não-discriminação como direito fundamental e as redes municipais de proteção a minorias sexuais - LGBT. Revista de Informação Legislativa, Brasília, a.47, n. 186, abr.-jun., 2010, p. 89-106. Disponível em http://www2.senado.leg.br/bdsf/bitstream/handle/id/496918/RIL186.pdf?sequence=1\#page= 90. Acesso em 29 jan. 2018.

BEAUVOIR, Simone de. O SEGUNDO SEXO, v.1, Portugal: Quetzal Editores, 2015.

BORRILLO, Daniel. O sexo e o Direito: a lógica binária dos gêneros e a matriz heterossexual da lei. Meritum, Belo Horizonte, v.5, n.2, p. 289-321, jul-dez., 2010. Disponível em file://C:/Users/Fabricio/Downloads/Dialnet-OSexoEODireito-4056871.pdf. Acesso em 29 jan. 2010.

BRASIL. Significado de Identidade de Gênero. Disponível em https://www.significados.com.br/identidade-de-genero/. Acesso em 29 jan. 2018. 
BRASIL. Lei 10.948, de 05 de novembro de 2001. Disponível em https://www.al.sp.gov.br/repositorio/legislacao/lei/2001/lei-10948-05.11.2001.html. Acesso em 24 jan. 2018.

BRASIL. Decreto 51.180, de 14 de janeiro de 2010, da Prefeitura de São Paulo. Disponível em https://transconnection.wordpress.com/2014/08/28/lei-nome-social-ou-leida-identidade- de-genero/. Acesso em 31 jan. 2018.

BRASIL. Constituição da República Federativa do Brasil de 1988. Disponível em http://www.planalto.gov.br/ccivil_03/constituicao/constituicao.htm. Acesso em 29 jan. 2018.

BRASIL. Decreto 8.727, de 28 de abril de 2016. Disponível em http://www.planalto.gov.br/ccivil_03/_ato2015-2018/2016/decreto/D8727.htm. Acesso em 24 jan. 2018.

BRASIL. Decreto 57.559, de 22 de dezembro de 2016. Disponível em http://www.sinesp.org.br/index.php/179-saiu-no-doc/1209-decreto-n-57-559-de-22-122016- uso-do-nome-social-e-reconhecimento-da-identidade-de-genero-de-travestismulheres- transexuais-e-homens-trans-no-ambito-da-administracao-publica-direta-eindireta. Acesso em 24 jan. 2018.

BRASIL. Decreto 55.588, de 17 de março de 2010. Disponível em https://www.al.sp.gov.br/repositorio/legislacao/decreto/2010/decreto-5558817.03.2010.html. Acesso em 31 jan. 2018.

BRASIL. Portaria 33, de 17 de janeiro de 2018, Ministério da Educação e Cultura. Disponível em http://www.migalhas.com.br/Quentes/17,MI272676,21048$\mathrm{MEC}+$ permite + uso + de + nome + social + de + transexuais + no + ensino + basico. Acesso em 24 de janeiro de 2018.

BRASIL. Lei 11.488, de 19 de janeiro de 2017. Disponível em https://leismunicipais.com.br/a/sp/s/sorocaba/lei-ordinaria/2017/1148/11488/lei-ordinarian- 11488-2017-dispoe-sobre-a-reorganizacao-da-estrutura-administrativa-da-prefeitura- 
municipal-de-sorocaba-e-da-outras-providencias. Acesso em 24 jan. 2018.

BUCCI, Maria Paula Dallari. DIREITO ADMINISTRATIVO E POLÍTICAS PÚBLICAS. São Paulo: Saraiva, 2006.

BUNCHAFT, Maria Eugênia; CRISTIANETTI, Jéssica. O julgamento da ADI 4277 do STF: uma crítica ao binarismo sexual à luz do debate Fraser-Honneth. Revista de Direito e Liberdade, v.18, n.2, maio-ago, 2016, p. 51-84. Disponível em file:///C:/Users/Fabricio/Downloads/1054-3327-1-PB.pdf. Acesso em 29 jan. 2018.

BUTLER, Judith. PROBLEMA DE GÊNERO - feminismo e subversão da identidade. Tradução Renato Aguiar, 8.ed., Rio de Janeiro: Civilização Brasileira, 2015 .

CARRARA, Sérgio. Políticas e direitos sexuais no Brasil contemporâneo. Bagoas Estudos Gays: gêneros e sexualidades, v.4, n.05, 2010, p. 131-147. Disponível em https://periodicos.ufrn.br/bagoas/article/view/2316/1749. Acesso em 29 jan. 2018.

DIAS, Alfrâncio Ferreira. Os estudos de gênero na pós-graduação em Educação do Norte e Nordeste. Educação e Igualdade de Gênero. Organização Alfrâncio Ferreira Dias e Maria Helena Santana Cruz. Jundiaí: Paco Editorial, 2015.

GALUPPO, Marcelo Campos. O que são direitos fundamentais? JURISDIÇÃO CONSTITUCIONAL E DIREITOS FUNDAMENTAIS. Coordenador: José Adércio Leite Sampaio. Belo Horizonte: Del Rey, 2003.

JESUS, Jaqueline Gomes de. Identidade de gênero e políticas de afirmação identitária. VI Congresso Internacional de Estudos sobre a Diversidade Sexual e de Gênero da ABEH, 2012. Disponível em https://www.researchgate.net/profile/Jaqueline_Jesus/publication/233854734_Identidade_de _genero_e_politicas_de_afirmacao_identitaria/links/0912f50c2612f1ea35000000.pdf. Acesso em 29 jan. 2018. 
JESUS, Jaqueline Gomes de. Transfobia e crimes de ódio: assassinatos de pessoas transgêneros como genocídio. HISTÓRIA AGORA - Revista de História do Tempo Presente, 2014, p. 101-123. Disponível em https://s3.amazonaws.com/academia.edu.documents/38611160/Transfobia_e_Crimes_de_O di

o_Genocidio.pdf?AWSAccessKeyId=AKIAIWOWYYGZ2Y53UL3A\&Expires=151735101 $4 \&$ Signature $=5$ vLxTIIokWWbOvDwkaA95n875ng\%3D\&response-contentdisposition=inline $\% 3 \mathrm{~B} \% 20$ filename\%3DTransfobia_e_crimes_de_odio_Assassinatos.pdf. Acesso em 30 jan. 2018.

LINS, Beatriz Accioly; MACHADO, Bernardo Fonseca; ESCOURA, Michele. DIFERENTES, NÃO DESIGUAIS - a questão de gênero na escola. São Paulo:

Editora Reviravolta, 2016.

LOURO, Guacira Lopes. GÊEERO, SEXUALIDADE E EDUCAÇÃO - uma perspectiva pós- estruturalista. Petrópolis: Editora Vozes, 2014.

LOPES, Laís. O que é o gênero? GÊNERO, SEXUALIDADE E DIREITO: UMA INTRODUÇÃO. Organização Marcelo Maciel Ramos; Paula Rocha Gouvêa Brener; Pedro Augusto Gravatá Nicoli. Belo Horizonte: Initia Via Editora, 2016.

MELO, Ferdinando Santos de. Gênero, Orientação Sexual e Educação: Reflexões conceituais e interfaces com o serviço social e a diversidade na escola. Educação e Igualdade de Gênero. Organização Alfrâncio Ferreira Dias e Maria Helena Santana Cruz. Jundiaí: Paco Editorial, 2015.

MELLO, Cláudio Ari. DEMOCRACIA CONSTITUCIONAL E DIREITOS FUNDAMENTAIS. Porto Alegre: Livraria do Advogado, 2004.

MOREIRA, Adilson José. CIDADANIA SEXUAL - estratégia para ações inclusivas. Belo Horizonte: Arraes Editores, 2017.

MOREIRA, Bárbara Antonina E. de Campos; FERNANDES, Bianca de Menezes; RIBEIRO, Brenda Senna Guimarães. O direito á saúde sob a ótica da hermenêutica dos 
direitos fundamentais. HORIZONTES HERMENÊUTICOS. Organizadora: Maria Helena Damasceno e Silva Megale. Belo Horizonte: Imprensa Universitária da UFMG, 2012.

MOREIRA, Eduardo Ribeiro. A possibilidade de controle judicial das políticas públicas. NOVOS RUMOS PARA O DIREITO PÚBLICO - Reflexões em homenagem à professora Lúcia Valle Figueiredo. Belo Horizonte: Editora Fórum, 2012.

PENNA, Saulo Versiani. CONTROLE E IMPLEMENTAÇÃO PROCESSUAL DE POLÍTICAS PÚBLICAS NO BRASIL. Belo Horizonte: Editora Fórum, 2011.

PINTO, Mariana Dórea Figueiredo. Trabalho, Educação e Gênero: problematizando a formação e a prática da mulher auditora independente no Brasil. Educação e Igualdade de Gênero. Organização Alfrâncio Ferreira Dias e Maria Helena Santana Cruz. Jundiaí: Paco Editorial, 2015.

POMBO, Mariana Ferreira. Desconstruindo e subvertendo o binarismo sexual e de gênero: apostas feministas e queer. Revista de Estudos Interdisciplinares em Gêneros e Sexualidades, Salvador, n. 7, v.1, maio-out., 2017, p. 388-404. Disponível em file://C:/Users/Fabricio/Downloads/21786-75897-1-PB.pdf. Acesso em 29 jan. 2017.

PORCHAT, Patrícia. PSICANÁLISE E TRANSEXUALISMO - desconstruindo gêneros e patologias com Judith Butler. Curitiba: Juruá, 2014.

SANTOS, Ana Lúcia. Para lá do binarismo? O intersexo como desafio epistemológico e político. Revista Crítica de Ciências Sociais, número 102, dezembro, 2013, p. 3-20. Disponível em file://C:/Users/Fabricio/Downloads/rccs-5421.pdf. Acesso em 29 jan. 2018.

SARLET, Ingo Wolfgang. A EFICÁCIA DOS DIREITOS FUNDAMENTAIS. 4.ed., Porto Alegre: Livraria do Advogado, 2004.

SEVERO, Rafael Adriano de Oliveira. GÊNERO E SEXUALIDADE NO COTIDIANO DA ESCOLA: a morte social causada pelo bullying homofóbico. OUTROS PLURAIS mulheres e homens na educação. Curitiba: Editora CRV, 2013. 
SEVERO, Rafael Adriano de Oliveira. GENERO \& SEXUALIDADE - Grupos de discussão como possibilidade formativa. Jundiaí: Paco Editorial, 2013.

SILVA, Rodrigo Gonçalves Lima Borges da; BEZERRA, Waldez Cavalcante; QUEIROZ, Sandra Bomfim de. Os impactos das identidades transgêneros na socialidade de travestis e mulheres transexuais. Revista de Terapia Ocupacional da Universidade de São Paulo, 26(3), set.-dez., 2015, p. 364-372. Disponível em file://C:/Users/Fabricio/Downloads/88052- 201436-1-PB.pdf. Acesso em 30 jan. 2018.

SILVEIRA, Ederson Luís. A dissolução da identidade em corpos complexos: para além do binarismo masculino/feminino. Revista Discente do Programa de Pós-Graduação em História da UFMG, v. 7, n. 2, maio-ago. 2015, p. 148-175. Disponível em file://C:/Users/Fabricio/Downloads/3342-8414-1-PB.pdf. Acesso em 29 jan. 2018.

SOARES, Mário Lúcio Quintão. DIREITOS FUNDAMENTAIS \& DIREITO COMUNITÁRIO - Por uma metódica de direitos fundamentais aplicada às normas comunitárias. Belo Horizonte: Del Rey, 2000.

VENCATO, Anna Paula. Confusões e estereótipos: o ocultamento de diferenças na ênfase de semelhanças entre transgêneros. Cadernos AEL, v.10, n.18/19, 2003, p. 187-215. Disponível em https://www.ifch.unicamp.br/ojs/index.php/ael/article/view/2513/1923. Acesso em 30 jan. 2018. 


\title{
REFLEXÕES JURÍDICAS PERSISTENTES APÓS O RECONHECIMENTO PELO STF DO DIREITO DAS PESSOAS TRANSGÊNERO À ADEQUAÇAO DO NOME E DO GÊNERO SEM A REALIZAÇAO DE CIRURGIAS
}

\author{
Tereza Rodrigues Vieira \\ Universidade Paranaense (Unipar) \\ Valéria Silva Galdino Cardin \\ Universidade Estadual de Maringá (UEM) e Centro Universitário de Maringá (Unicesumar)
}

\begin{abstract}
Resumo
O presente artigo objetiva lançar algumas reflexões acerca de importantes questões éticas e jurídicas com as quais a pessoa transgênero se depara, mesmo após a decisão do Supremo Tribunal Federal brasileiro sobre a Ação Direta de Inconstitucionalidade, ADI 4275, que reconheceu a possibilidade de alteração de prenome e gênero no registro civil sem a realização de procedimentos cirúrgicos. Utiliza-se o método teórico-empírico baseado em estudos bibliográficos para correlacionar os fundamentos citados à nossa experiência na advocacia em questões concernentes à adequação de nome e gênero.
\end{abstract}

Palavras-chave: Criança e adolescente, Despatologização, Nome civil, Registro civil, Transgênero.

\section{Abstract/Resumen/Résumé}

This article presents some reflections on important legal issues that the transgender person faces, even after the decision of the Brazilian Federal Supreme Court on the Direct Action of Unconstitutionality, ADI 4275, which recognized the possibility of altering the first name and gender in the civil registry without performing surgical procedures. The theoretical-empirical method based on bibliographic studies is used to link the cited foundations with to our experience in advocacy on issues concerning name and gender adequacy. 
Keywords/Palabras-claves/Mots-clés: Transgender, Despatologization, Child and adolescent, Civil registry, Civil name.

\section{Introdução}

Estudos acerca da identidade de gênero passaram a desfrutar de maior visibilidade no campo do direito nas últimas décadas. Contudo, as pessoas trans continuam a padecer com a discriminação e o preconceito concernentes à transgeneridade.

Assim, o presente trabalho objetiva lançar reflexões que permeiam importantes questões ainda carentes de discussão atinentes à pessoa transgênero. Utiliza-se o método teórico-empírico baseado em doutrina, legislação e normas éticas, para correlacionar os fundamentos citados à nossa experiência advocatícia cotidiana em questões que se referem à adequação do prenome e gênero no registro civil da pessoa trans.

Anote-se aqui, recente avanço do judiciário brasileiro em reconhecer através de decisão do Supremo Tribunal Federal sobre a Ação Direta de Inconstitucionalidade, ADI 4275, a possibilidade de alteração de prenome e gênero no assento de registro civil sem a realização de procedimento cirúrgico. Referido julgamento demonstrou a crucial importância da consolidação dos direitos fundamentais para o reconhecimento da identidade de gênero para a dignidade da pessoa humana, porém, ainda, persistem inúmeros pontos que ensejam polêmicas não apaziguadas.

Destarte, os questionamentos pululam, ainda que já adequados o registro da pessoa extrans. Neste tocante surgem questões como: Pessoa com a documentação já adequada deve informar ao futuro cônjuge que foi transexual ou neste aspecto cabe direito ao esquecimento? A não informação implica em anulação do casamento caso o cônjuge se sinta enganado com a omissão da cirurgia de transgenitalização? A imagem da pessoa transgênero encontrará algum óbice prático ao realizar a mudança no Registro Civil e nos demais documentos? A sociedade pressiona a pessoa trans a modificar fisicamente seu corpo para "parecer homem ou parecer mulher"? Para ser considerado homem tem que "parecer homem"? O que é ser homem ou ser mulher? Para fazer uso dos banheiros separados por gênero a imagem pode gerar discriminação e impedimento? É possível servir às forças armadas sem a realização de cirurgias transgenitalizantes? A dispensa do serviço militar deve ocorrer mesmo quando a pessoa trans deseja servir às forças armadas? Qual seria o motivo oficial para eventual dispensa? Estas e outras questões afins merecem reflexões percucientes, uma vez que a matéria apresenta aspectos multidisciplinares 
Mesmo não sendo pessoas doentes e não possuírem anomalia genital ou mental justifica-se este estudo acerca das pessoas transgênero em decorrência da exposição às violências e destituição de direitos se comparadas às pessoas cisgênero, portanto fadadas à discriminação social.

\section{Efetivação material do direito à igualdade}

Considerando que o Estado é detentor do poder de determinar sobre a forma mais apropriada, os trâmites e procedimentos para a mudança de nome e gênero, bem como a adequação de imagem, em todos os registros e documentos para que estejam conformes à identidade de gênero autopercebida, o Supremo Tribunal Federal enfrentou polêmica matéria e ponderou acerca de inúmeros pontos referentes aos direitos das pessoas trans.

Registre-se aqui que:

[...] O termo pessoa trans procura discursivamente valorizar as trajetórias sociais e identitárias, os rituais de modificação corporal, as violências enfrentadas no cotidiano e as dificuldades que travestis e mulheres transexuais compartilham no decorrer da vida, por subverterem os cânones sobre gênero e sexualidade e a estilística heteronormativa de performatizar a relação corpo, genitália e desejo. (SANTOS, 2014, p.89)

A decisão do Supremo Tribunal Federal sobre a Ação Direta de Inconstitucionalidade, ADI 4275, proferida em $1^{\circ}$. de março de 2018 (STF, 2018), deu importante passo para a efetivação do direito ao nome e ao gênero das pessoas transgênero. A ação fora ajuizada pela Procuradoria-Geral da República (PGR) com o intuito de que o artigo 58 da Lei 6.015/1973, Lei dos Registros Públicos, fosse interpretado conforme a Constituição Federal.

Os ministros Edson Fachin, Luiz Roberto Barroso, Luiz Fux, Rosa Weber, Celso de Mello e Cármen Lúcia entenderam que nem a autorização judicial nem a cirurgia seriam necessárias. Os Ministros vencidos foram Marco Aurélio (relator), Alexandre de Moraes, Ricardo Lewandowski e Gilmar Mendes que consideraram necessário procedimento de jurisdição voluntária com autorização judicial para a alteração, embora reconhecessem a desnecessidade de cirurgias.

Nenhum regime democrático pode admitir que a minoria seja oprimida por grupos majoritários, uma vez que é dever da Corte a proteção das minorias discriminadas.

Segundo o Ministro Celso de Mello, se surgir alguma situação objetiva que possa eventualmente assinalar prática fraudulenta ou abusiva, competirá ao oficial do registro civil 
das pessoas naturais a estabelecimento do processo administrativo de dúvida. (PLENARIO, 2018)

Consoante a então presidente do Supremo Tribunal Federal, ministra Cármen Lúcia, o julgamento "marca mais um passo na caminhada pela efetivação material do princípio da igualdade, no sentido da não discriminação e do não preconceito". "O Estado há que registrar o que a pessoa é, e não o que acha que cada um de nós deveria ser, segundo a sua conveniência”. (STF, 2018, p.1)

Proferiu seu voto com supedâneo no direito à honra, à imagem, à vida privada, nos princípios constitucionais da igualdade material, da liberdade, da dignidade e no direito de ser diferente. (STF, 2018, p.1)

Assim, o STF pacificou o entendimento de que a retificação do registro civil das pessoas transgênero deve ser desburocratizado e realizado diretamente nos cartórios do registro civil, sendo desnecessário o processo judicial, segundo a maioria. Dispensar-se-á, também, a apresentação de pareceres médicos ou psicológicos, segundo a totalidade dos ministros, respeitando-se a maioridade civil e a representação dos menores de idade.

A decisão acima corrobora o reivindicado no Projeto de Lei $\mathrm{n}^{\circ} 134$ de 2018, em tramitação no Senado Federal, que institui o Estatuto da Diversidade Sexual e de Gênero (SENADO, 2018), nos dispositivos abaixo:

Art. 40 - A alteração do nome e da identidade sexual pode ser requerida diretamente junto ao Cartório do Registro Civil, sem a necessidade de ação judicial ou a representação por advogado, garantida a gratuidade do procedimento.

$\S 1^{\circ}$ - A alteração será averbada no Livro de Registro Civil de Pessoas Naturais.

$\S 2^{\circ}$ - Nas certidões não podem constar quaisquer referências à mudança levada a efeito, a não ser a requerimento da parte ou por determinação judicial.

$\S 3^{\circ}$ - No caso de crianças e adolescentes, o pedido de retificação deve ser feito pelos pais ou responsáveis, ouvido o Ministério Público.

$\S 4^{\circ}$ - A falta de consentimento dos pais ou responsáveis pode ser suprimida judicialmente.

Art. 41 - Procedida a alteração registral, é assegurada a retificação em todos os outros registros e documentos, sem qualquer referência à causa da mudança.

Destarte, para a suprema corte brasileira, a vida privada deve ser diretamente construída pela pessoa interessada, não pelo Estado. Os princípios da dignidade da pessoa humana, da integridade física e da autonomia da vontade são violados quando se condiciona a adequação desejada à realização de procedimentos cirúrgicos ou de alguma outra forma, para que se comprove a identidade de uma pessoa. 


\subsection{Procedimento junto ao Cartório}

Com a decisão do STF em autorizar o procedimento extrajudicial para a adequação do prenome e do gênero diretamente no Cartório do Registro Civil de Nascimento, muitas pessoas trans se dirigiram a esta repartição em busca da efetivação deste direito. Sucede que a maioria dos notários rejeitava a realização da referida mudança sem estabelecimento dos requisitos pelo Conselho Nacional de Justiça (CNJ).

Não é despiciendo informar que é função do Conselho Nacional de Justiça aperfeiçoar a tarefa do sistema judiciário brasileiro, sobretudo no que concerne à transparência administrativa e processual. Vários estados da federação publicaram regulamentação, porém não era uniforme.

Assim, visando regulamentar a questão, o Conselho Nacional de Justiça, por meio do Provimento 73, de 28 de junho de 2018, dispôs sobre à averbação da mudança do prenome e do gênero nos assentos de nascimento e casamento da pessoa transgênero no Registro Civil das Pessoas Naturais (RCPN).

Estabeleceu o Provimento 73/2018 do Conselho Nacional de Justiça que toda pessoa maior de 18 anos completos habilitada à prática de todos os atos da vida civil poderá requerer ao ofício do RCPC a alteração do prenome e do gênero, a fim de adequá-los à identidade autopercebida. Referido provimento nada menciona sobre o reconhecimento pela via administrativa para os menores.

\section{Adequação do nome da criança e do adolescente}

Um dos grandes problemas para aqueles que ainda não mudaram prenome e gênero junto ao Cartório do Registro Civil, é o uso do nome publicamente. Para tal, a opção é o uso do nome social, ou seja, aquele pelo qual a pessoa transgênero opta por ser chamada socialmente, de conformidade com sua identidade de gênero.

O Decreto n. 8727 , de 28 de abril de 2016, dispõe sobre o uso do nome social e o reconhecimento da identidade de gênero de pessoas travestis ou transexuais no âmbito da administração pública federal direta, autárquica e fundacional.

No Brasil, o Ministério da Educação e Cultura (MEC) autoriza uso de nome social na educação básica, que inclui a educação infantil, o ensino fundamental e o ensino médio, para travestis e transexuais. A Resolução do MEC foi homologada dia 17 de janeiro de 2018. A 
norma objetiva difundir o respeito e diminuir estatísticas de violência e abandono da escola em decorrência de bullying, constrangimento, assédio moral, preconceitos e discriminação. $\mathrm{O}$ Conselho Nacional de Educação já havia aprovado o texto desde setembro de 2017.

Por fim, o Ministério da Educação atendeu demanda dos movimentos LGBTIs, afinal, é obrigação daquela pasta, fomentar o debate nas escolas acerca das questões de gênero com toda a comunidade escolar e implementar ações eficazes de luta contra o preconceito. Referida Resolução incentiva que as escolas de educação básica instituam diretrizes e práticas para o combate a quaisquer formas de discriminação em decorrência de orientação sexual e identidade de gênero dos professores, estudantes, funcionários, gestores e elaborem propostas curriculares e modelos pedagógicos.

Ressalte-se aqui que as pessoas trans que se candidatam ao Exame Nacional do Ensino Médio (ENEM) já podiam fazer uso do nome social desde 2014 e hoje já ultrapassa centenas de estudantes os inscritos que se utilizaram desse expediente.

Lamentavelmente, o direito das crianças e adolescentes a adequarem nome e gênero pela via extrajudicial diretamente no Cartório, não foi contemplado pelo Provimento 73/2018. O Instituto Brasileiro de Direito de Família IBDFAM recomendou ao CNJ a uniformização do procedimento de alteração de registro civil de transgêneros, sugerindo para os menores (Pedido de Providências 0002077-79.2018.2.00.0000):

[...] No caso de adolescente maior de 12 anos, este deve estar representado por ambos os genitores. $\mathrm{O}$ adolescente maior de 16 anos deve ser assistido por ambos os genitores. Todos devem comparecer perante o registrador e firmar o termo de consentimento informado. A alteração pode ser solicitada perante qualquer Serviço do Registro Civil do País, bem como nas repartições diplomáticas brasileiras no exterior. O procedimento completo foi detalhado em minuta composto por 19 artigos e modelos para uniformizar o processo em todo o País. (IBDFAM, 2018)

Importante ressaltar que o sofrimento de uma criança é desumano quando descobre que seu comportamento é emoldurado como diferente da norma sugerida pela sociedade aos pertencentes ao gênero atribuído na sua Certidão de Nascimento.

Satisfazer cegamente algo que não optou para o resto de sua vida é impiedoso demais. Compreender que a imagem projetada no espelho não satisfaz integralmente ao que a coletividade espera de um menino, por exemplo, pode ocasionar angústia inimaginável. (VIEIRA, 2013)

De acordo com Kaas, "alguns críticos dizem que o número crescente de adolescentes transgênero se deve a pais urbanos e liberais indo longe demais com crianças que poderiam apenas estar fazendo experiências e testando convenções." (KAAS, 2015) 
Em processo tramitado em São Paulo, em um dos fóruns da capital, em 2013, obtevese êxito em pedido judicial de menor para a adequação do Registro Civil. A magistrada do caso ponderou:

[...] Não é justo nem aceitável submeter a requerente a mais alguns anos de sofrimentos, angústia, vexames e vergonhas. Se há uma medida judicial que pode contribuir com o seu bem-estar, com a sua adequação à sociedade, com seu amor próprio, que vai lhe deixar mais feliz, e até mais preparada para enfrentar todas as dificuldades que a vida lhe reserva, não há motivo justo para o judiciário lhe voltar as costas. Não permitir a referida alteração, com fundamento exclusivamente em sua menoridade, corresponderia condená-la a conviver por mais três anos com os conflitos que a atormentam e, inegavelmente, atingem a dignidade da pessoa humana protegida pela Constituição Federal. [...]. Assim, ante o exposto, ausentes indícios de prejudicialidade para terceiros, manifesto-me favoravelmente à pretensão contida na inicial. (VIEIRA, 2013, p. 22-24)

A propósito, em 2016, o magistrado Anderson Candiotto, da $3^{\text {a }}$ Vara da Comarca de Sorriso, Mato Grosso, possibilitou a adequação para o feminino do prenome e do gênero de criança de nove anos. (MENINO, 2016)

A não aceitação social pode impedir o bem-estar e a segurança da pessoa trans, podendo levar à depressão ou ao suicídio. Contudo, quanto maior o auxílio, melhor a saúde mental. O amparo familiar, por exemplo, aparece como um extraordinário fator de proteção de saúde mental entre pessoas trans, incluindo crianças e adolescentes (MCCONNELL, BIRKETT e MUSTANSKI, 2015; SHERER, 2016; SIMONS et al., 2013, apud VIEIRA e PAYA, 2017).

Relembre-se aqui que o Provimento 73/2018 é omisso no caso dos menores, no tocante à adequação do seu nome e gênero, restando-lhes a proposição de Ação Judicial. Assim, cabe à família ou responsáveis legais, o fundamental acolhimento na redução de danos sociais e psicológicos nesta importante fase do desenvolvimento, contribuindo para afirmação da identidade e promoção do bem-estar.

\section{Adequação do nome do pai ou da mãe transexual no registro dos filhos maiores e menores}

Em decorrência do preconceito e discriminação, por vezes, dos pais, que hesitam em mudar a certidão dos filhos menores, pois esta atitude leva à inserção do seu novo prenome, passando a ter no espaço destinado aos genitores dois nomes aos quais a sociedade atribui como femininos ou masculinos. Muitas vezes, o genitor cisgênero entende que a ele será imputada uma relação homoafetiva não verdadeira, uma vez que, quando se casou, o outro não tinha 
revelado sua transexualidade. Se os responsáveis legais não solicitarem, a mudança no registro do filho menor não acontecerá. Percebe-se, assim, que o temor do genitor cisgênero engloba eventual discriminação do filho e também em relação a sua própria pessoa.

Destaque-se aqui, que o genitor cisgênero não deve reproduzir o preconceito internalizado pela sociedade, pois a diversidade sexual deve ser vista com naturalidade, uma vez que não é considerada doença. Já houve bastante progresso na jurisprudência no tocante ao respeito à diversidade sexual e os pais devem educar os seus filhos para a diversidade, respeito ao diferente e inclusão social. Os pais cisgêneros devem evitar alienação parental em decorrência da transexualidade do outro cônjuge, assédio moral e ataque a autoestima, pois isto poderá causar danos e efeitos negativos no bem estar do próprio filho, transformando-o em sujeito transfóbico e intolerante às minorias sexuais.

No caso de filho maior de idade, a adequação do nome do genitor na certidão do descendente depende da anuência deste. Em anos passados, quando o próprio genitor em seu processo solicitava a referida adequação do seu nome no registro do filho maior, exigia-se autorização específica por escrito do descendente para que se efetuasse o mandado destinado ao Cartório de Registro Civil no qual estava registrado o assento do filho.

Assim, o filho maior de idade é quem tem legitimidade para requerer a alteração em seu próprio assento no tocante ao novo nome do genitor trans. No caso de menores, os pais têm legitimidade para demandar alterações no Registro Civil destes filhos. (VIEIRA, CARMO GOMES, 2017)

A transgeneridade não tira da pessoa a idoneidade para instruir e educar uma criança, nem depõe contra sua moral. Tampouco a transgeneridade testemunha contra a natureza moral do indivíduo, nem embate contra os interesses do filho menor. (VIEIRA, 2012)

É essencial que a veracidade sobre a filiação seja representada na documentação do filho, caso contrário, sujeitará o genitor ao não exercício pleno do poder familiar ou impedirá o cumprimento de obrigações, com base no hipotético erro na filiação. O convívio com o filho é manifestamente importante para aquele que adequou sua documentação.

A convivência familiar com a pessoa trans não desmerece proteção estatal. O Estatuto da Criança e Adolescente, o Código Civil e a Constituição Federal devotam o dever da família, bem como da sociedade e do Estado, garantir à criança e ao adolescente todos os direitos intrínsecos a pessoa humana, observando a sua qualidade de pessoa em desenvolvimento. (BRASIL, 2013) Logo, é importante o auxílio profissional de um psicólogo em decorrência da vulnerabilidade da criança, dependendo da idade e estágio de desenvolvimento que atravessa. 
Afirma Luiz Edson Fachin que o princípio do melhor interesse da criança é critério "significativo na decisão e na aplicação da lei. Isso revela um modelo que, a partir do reconhecimento da diversidade, tutela os filhos como seres prioritários nas relações paternofiliais e não mais apenas a instituição familiar em si mesma." (1996, p. 98)

Obviamente, a Certidão de Nascimento não deve inscrever "pai" ou "“mãe" e sim "filiação". De igual maneira, não necessita constar avós "maternos" e "paternos", bastando somente "avós". Dessa forma, não haverá eventual constrangimento nem para o registrado nem para seu genitor. (VIEIRA, LAURENTIS, 2015)

Concernente aos descendentes, frise-se aqui que, o Provimento 73 (CNJ, 2018) dispõe em seu artigo $8^{\circ}$ que :

\footnotetext{
$1^{\circ}$ A pessoa requerente deverá providenciar a alteração nos demais registros que digam respeito, direta ou indiretamente, a sua identificação e nos documentos pessoais.
}

$2^{\circ}$ A subsequente averbação da alteração do prenome e do gênero no registro de nascimento dos descendentes da pessoa requerente dependerá da anuência deles quando relativamente capazes ou maiores, bem como da de ambos os pais.

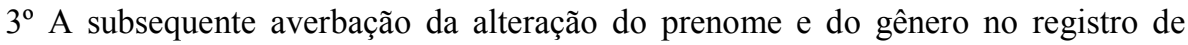
casamento dependerá da anuência do cônjuge.

$4^{\circ}$ Havendo discordância dos pais ou do cônjuge quanto à averbação mencionada nos parágrafos anteriores, o consentimento deverá ser suprido judicialmente.

Isto posto, a relação entre pais transexuais e seus filhos deve ser cercada de afeto e vivida em ambiente respeitoso e seguro, como em qualquer outro núcleo familiar.

\section{Serviço Militar}

O alistamento militar é obrigatório para todo brasileiro do "sexo" masculino e deve ser realizado nos primeiros seis meses do ano em que completar 18 anos de idade. As mulheres estão isentas do serviço militar obrigatório, conforme prevê a Constituição Federal, contudo podem integrar as Forças Armadas por meio de concurso público. E o Certificado de Alistamento Militar (CAM) é o documento que comprova a apresentação para a prestação do Serviço Militar.

Vale salientar que o recrutamento militar compreende as seguintes fases: alistamento, seleção (aspectos físico, cultural, psicológico e moral), distribuição (encaminhado à Marinha, Exército ou Aeronáutica), e a incorporação (ingresso nas Forças Armadas). (BRASIL, 2018) 
Segundo a Lei do Serviço Militar n. 4.375/1964, no decorrer do alistamento militar, o brasileiro que apresenta aparente incapacidade física e/ou mental estará isento do Serviço Militar e poderá demandar na Junta de Serviço Militar, o seu Certificado de Isenção. Outros casos de incapacidade física e/ou mental não aparentes necessitam ser avaliados.

Considerando-se o acima exposto, indaga-se: É possível servir às forças armadas sem a realização de cirurgias transgenitalizantes? A transexualidade implica em dispensa automática? A eventual dispensa, se houver, poderá ser embasada nos aspectos físicos e psicológicos? Ter ou não se submetido às cirurgias chamadas transgenitalizantes, após acompanhamento psicológico, diferencia este candidato dos demais? Afinal, qual a finalidade do serviço militar obrigatório?

Conforme o art. $1^{\circ}$ da Lei $n^{\circ} 4.375 / 64$, o serviço militar consiste no exercício de atividades específicas desempenhadas nas Forças Armadas, ou seja, no Exército, Marinha ou Aeronáutica, e compreenderá, na mobilização, todos os encargos relacionados com a defesa nacional. $\mathrm{O}$ referido serviço tem por finalidade a formação de reservas destinadas a atender as necessidades de pessoal das Forças Armadas, no que se refere aos encargos relacionados com a Defesa Nacional, em caso de mobilização.

Estes pontos merecem reflexões percucientes, uma vez que o tema apresenta aspectos multidisciplinares.

Enfatize-se aqui que, se não estiver em dia com as suas obrigações militares, o cidadão do "sexo masculino" não poderá:

[...] Obter passaporte ou prorrogação de sua validade; Ingressar como funcionário, empregado ou associado em - instituição, empresa ou associação oficial, oficializada ou subvencionada; Assinar contrato com o Governo Federal, Estadual, dos Territórios ou Municípios; Prestar exame ou matricular-se em qualquer estabelecimento de ensino; Obter carteira profissional, registro de diploma de profissões liberais, matrícula ou inscrição para o exercício de qualquer função e licença de indústria e profissão; Inscrever-se em concurso para provimento de cargo público; Exercer, a qualquer título, sem distinção de categoria ou forma de pagamento, qualquer função pública ou cargo público, eletivos ou de nomeação; Receber qualquer prêmio ou favor do Governo Federal, Estadual, dos Territórios ou Municípios. (BRASIL, 2018)

Como é manifesto, considerando-se a obrigatoriedade do alistamento para os cidadãos do sexo masculino, a habilitação para um emprego implica na apresentação de certificado que comprova a sua situação militar. A princípio, se o indivíduo não o tiver, não poderá ser contratado.

Diante da ausência de lei, o Ministério da Defesa, questionado pela Defensoria Pública do Estado do Rio de Janeiro, confirmou a necessidade de alistamento militar para os homens transexuais 
que possuem os documentos já adequados. A partir de 2018 o alistamento militar pode ser feito de forma online pelo site www.alistamento.eb.mil.br.

Sobre o assunto, a título de lege ferenda, dispõe o Projeto de Lei n.134, que institui o Estatuto da Diversidade Sexual e de Gênero (SENADO, 2018), que tramita no Senado Federal brasileiro:

Art. 42 - Transgêneros e intersexuais podem ser dispensados do alistamento militar, mediante simples requerimento encaminhado à Junta do Serviço Militar.

Art. 43 - Será concedido ou cancelado o Certificado de Alistamento Militar - CAM, mediante a apresentação de certidão de inteiro teor onde conste a alteração levada a efeito.

As forças armadas, com o Serviço Militar, asseguram a representatividade geográfica, étnica, social e religiosa de seus integrantes. Deve ser bem-vinda a representatividade da diversidade sexual também.

\section{Da anulação ou não do casamento com transgênero que não revela sua condição anterior}

Nas últimas décadas, o Brasil vem reconhecendo novos tipos de família, ampliando suas configurações. De acordo com o art. $3^{\circ}$ do Estatuto das Famílias do Instituto Brasileiro de Direito de Família, IBDFAM - a família pode ser definida como "[...] toda comunhão de vida instituída com a finalidade de convivência familiar, em qualquer de suas modalidades." (IBDFAM, 2007, p. 23). No entendimento da psicóloga e terapeuta de casais, Ana Cristina Canosa (2017):

[...] embora o casamento antes considerado "normativo", baseado na relação monogâmica de amor e sexo entre um homem e uma mulher, com fins procriativos e formação da chamada família nuclear, passa a ser um modelo vivido por alguns e considerado o único possível por grupos extremamente conservadores, não o é para boa parte da população brasileira, que se não vive, ao menos apoia outras possibilidades de relação de compromisso. (CANOSA, 2017)

A pessoa trans, antes ou depois da adequação do nome e gênero, evidentemente, poderá contrair matrimônio. Também poderá fazê-lo, independentemente de cirurgias. Contudo, o que se questiona aqui é a possibilidade ou não de uma eventual anulação do casamento, caso a pessoa trans tenha omitido do cônjuge seu estado anterior à adequação dos documentos. 
No entender de Maria de Fátima Freire de Sá e Bruno Torquato de Oliveira Naves:

O transexual redesignado deverá obter novo registro civil que conste seu novo gênero e prenome. Tem o transexual, entretanto, a obrigação de informar as pessoas com quem se envolva conjugalmente de sua especial condição, sob pena de ficar claro o error in persona, possibilitando a anulação do casamento. (SÁ; NAVES, 2018, p.325)

Em sua maioria, as pessoas trans, por se perceberem "mulheres" ou "homens, ponderam que suas relações afetivo-sexuais com parceiros homens ou mulheres são heteroafetivas e não homoafetivas. Destarte, a pessoa trans, em geral, entende o seu relacionamento como heteroafetivo, uma vez que o que mais influi não é o sexo biológico, mas a identidade de gênero que cada um desempenha no âmbito familiar, havendo assim uma semelhança com as famílias tradicionais. (DIAS, 2017A).

De conformidade com o disposto no Art. 1.556 do Código Civil, o casamento pode ser anulado por vício da vontade, se houve por parte de um dos nubentes, ao consentir, erro essencial quanto à pessoa do outro. E, também, quando o seu conhecimento ulterior tornar insuportável a vida em comum ao cônjuge enganado (art. 1.557, I, CCB). Cabe provar, que, sem o erro o matrimônio não teria ocorrido, ou seja, há o reconhecimento da existência de um vício no casamento que impede um convívio harmonioso, mediante prova de condição anteriormente ignorada pelo cônjuge, tornando insuportável a convivência do casal.

Têm a doutrina e a jurisprudência brasileiras assentido como termo de decadência, o de três anos, para que o cônjuge efetive o direito de anular o casamento nas hipóteses de erro essencial.

Hodiernamente, graças ao reconhecimento dos direitos das pessoas transgênero, a discriminação vem paulatinamente diminuindo, consequentemente, torna-se mais rara, porém não impossível, a possibilidade de alguém anular casamento sob esta alegação. O estado atual da pessoa deveria ser considerado mais importante que o seu passado transexual, vivido com sofrimento e desgosto, o qual deseja tanto esquecer, uma vez que se sente pertencente ao gênero que reivindicou e o Estado permitiu-lhe a alteração.

Em verdade, não há um esquecimento total da vida pregressa da pessoa trans que adequou seus documentos, uma vez que os números dos documentos continuam os mesmos. A vida precedente da pessoa não foi apagada, há uma continuidade, porém com outro nome e gênero.

Dessa forma, o direito ao esquecimento não se apresenta apenas como um direito supérfluo, mas que a subjetividade de sua aplicação pode ser fundamento decisivo para a saúde 
psicológica das pessoas trans, as quais passaram por transtornos e conflitos que merecem ser sepultados. Trata-se de intimidade que deve ser revelada somente em momentos essenciais e, na medida do possível, mantidas sob sigilo.

A pessoa trans tem direito ao seu planejamento familiar, através da autodeterminação, uma vez que não deseja ver perturbado seu equilíbrio emocional interno, bem como as vivências externas, arrebatando a paz e o bem-estar quando defrontados com sua vida anterior. Corroborando este entendimento, Machado e Bandeira afirmam que o bem-estar psicológico é um "construto multidimensional que reflete características relativas ao funcionamento psicológico positivo ou ótimo”. (MACHADO, BANDEIRA, 2012, p.587)

Embora exista a possibilidade da adoção transparental, há pessoas que possuem projeto parental com prole própria e sem uso de doação de óvulo e gestação solidária.

A propósito, a título de ilustração, cite-se aqui posicionamento de Alves e Gofas (2017) com o qual se anui facilmente, no que se refere à pessoa trans e seu direito ao esquecimento no ciberespaço:

[...] a aplicação do direito ao esquecimento no ciberespaço é uma forma de garantir os direitos da personalidade do transexual, na medida em que este figura-se como um sujeito incapaz de lutar pela preservação de seus direitos de personalidade, ante a dimensão da sociedade em rede. Cumpre ressaltar, porém, que a aplicação daquele direito não é solução plena para assegurar a plena garantia destes direitos na sociedade informacional, haja vista a própria complexidade da rede, sendo um caminho inicial a ser percorrido, enquanto temática que ainda necessita de muito diálogo para enfrentar os desafios de sua efetivação. (ALVES; GOFAS, 2017, p.97)

Indubitavelmente, um dos grandes dilemas pelos quais passa a pessoa trans é se tem a obrigação moral de contar àquela pessoa com a qual se tem um relacionamento amoroso e que está migrando para o compromisso mais sério e duradouro.

Primeiramente, quem decide se deve ou não contar é a própria pessoa e não deve haver obrigação de contar, incumbindo a ela refletir, se no seu contexto de relacionamento, há confiança para viver ao lado daquela pessoa pelo resto da vida ocultando algo que foi importante na sua trajetória e que não é considerado crime, embora ainda avaliado por algumas mentes mais convencionais, como algo reprovável.

Por outro lado, considerando a confiança como base para o casamento, é possível que o cônjuge queira conhecer os fatos mais relevantes da vida da pessoa com quem ele escolheu para viver até o fim dos seus dias. Pode ser que para a maioria seja muito constrangedor e complexo, falar sobre algo que sempre negou em decorrência do profundo sofrimento causado. 
Há que considerar aqui, a possibilidade de ajuda profissional de um psicólogo ou terapeuta, para encontrar o caminho menos angustiante para o casal.

Se na base da relação houver amor, compreensão e respeito, é possível dar a chance à outra pessoa de aceitar a pessoa transgênero como ela realmente é, sem diminuir o outro pela falta de confiança. O período correspondente ao namoro é importante para o conhecimento recíproco. Viver com receio e medo de ser um dia descoberta a omissão de outra forma, sujeita a chantagem, poderá tornar tudo muito pior. Se porventura contar e, o outro não aceitar, é porque aquele talvez não fosse o parceiro apropriado.

O relacionamento que se deseja para toda a vida será bem mais honesto se for totalmente transparente. A honestidade é exigida de todos aqueles que desejam uma vida conjugal plena. O futuro parceiro pode querer ter filhos biológicos, algo impossível a uma mulher trans. Ademais, em geral, quando a transição começa, a pessoa já estabeleceu relações sociais com muita gente, seja na escola, com familiares, no trabalho e a chance de encontrar pessoas do passado pode colocar o cônjuge em situação constrangedora, considerando-se traído e despreparado para enfrentar aquela situação. Um parceiro que não está disposto a assumir uma relação com uma pessoa trans, pode não ter condições estruturais para lidar com as suas demandas emocionais e psicológicas.

As pessoas trans militantes, em geral, não enfrentam este tipo de problema com o futuro cônjuge, pois são conhecidas como realmente são. O preconceito internalizado pode impedir que a pessoa trans seja aceita por completo. Trata-se de uma decisão íntima, de como a pessoa trans se sente mais confortável, sabendo que a omissão poderá implicar em riscos do passado vir à tona contra sua vontade.

Há percalços burocráticos no cotidiano que levam a pessoa que já adequou o nome e gênero no Registro Civil a temer pela revelação do passado trans, como por exemplo, alistamento militar, exame de DNA, adoção de criança, pedido de cidadania, tratamentos médicos, cirurgias invasivas, solicitação de visto que indaga se o candidato já efetuou alguma mudança de nome etc.

Entende-se que revelar ou não é uma questão de escolha da pessoa trans, porém se o futuro cônjuge demonstra ser uma pessoa preconceituosa, homofóbica ou transfóbica, certamente não é o consorte ideal. A ética deve estar presente em todas as ações e atitudes, sobretudo em relação àquela pessoa com quem se pretende dividir uma vida conjugal, na tristeza e na alegria, na saúde e na doença, onde não tem cabimento propositadas omissões acerca da sexualidade, reprodução e identidade, âmbitos sopesados fundamentais em uma união 
civil ou casamento. As pessoas fazem planos de uma vida em comunhão e harmonia duradouras. A felicidade só pode ser construída onde há ética entre o casal, confiança e lealdade.

\section{Uso de banheiros e vestiários de acordo com o gênero}

O uso dos banheiros em lugares públicos ainda continua sendo polêmico, em decorrência, principalmente da aparência física das pessoas trans e do preconceito das pessoas cis. Marcos Renato Benedetti ao cotejar a linguagem com a construção do corpo trans, sustenta que:

[...] o corpo das travestis é, sobretudo, uma linguagem; é no corpo e por meio dele que os significados do feminino e do masculino se concretizam e conferem à pessoa suas qualidades sociais. É no corpo que as travestis se produzem enquanto sujeitas (2005, p. 11).

Compete aqui externar as palavras de Butler (2016, p. 26):

Quando o status construído do gênero é teorizado como radicalmente independente do sexo, o próprio gênero se torna um artifício flutuante, com a consequência de que homem e masculino podem, com igual facilidade, significar tanto um corpo feminino como um masculino, e mulher e feminino, tanto um corpo masculino como um feminino. (BUTLER, 2016, p.26)

Isto posto, indaga-se: Para fazer uso dos banheiros em lugares de acesso ao público, a aparência física deve expressar o semblante que a sociedade espera de uma mulher ou de um homem?

Entende-se que não, pois isto é uma questão cultural, portanto a diversidade deve ser respeitada. Nem todas as mulheres têm cabelos longos, usam maquiagem, tem seios fartos ou têm a mesma compleição física. Nem todos os homens têm cabelos curtos, barba ou calvície.

Conforme registram Rocon et al (2018, p.49):

[...] O trânsito nos gêneros realizado pela população trans também acontece no campo da linguagem, tornando a modificação do nome próprio e do gênero nos pronomes de tratamento em elementos constantemente associados às transformações físicas do corpo. Essas mudanças linguísticas, reivindicadas em dissonância com as normas hegemônicas de sexo/gênero, funcionam como recurso condicionante para $o$ empreendimento da transformação corporal. Desse modo, a linguagem funciona como um campo de produção de vida [...] Não é dicotômica a relação entre corpo físico/biológico e linguagem/ cultura; assim, para as pessoas trans, as alterações na 
linguagem podem ser tão importantes quanto as modificações nas estruturas físicas do corpo.

O direito de usar o banheiro em lugares públicos de acordo com a identidade de gênero está implicitamente autorizado, contudo, apesar disso, muitos estados da federação já se ocuparam da sua regulamentação. Assim, é evidente que todos aqueles que obtiveram a adequação do nome e gênero no Registro Civil também o podem. O desrespeito ao pudor é conduta reprovável, seja por parte da pessoa trans ou cis.

Cumpre não olvidar o disposto na Constituição Federal brasileira, em seu artigo $5^{\circ}$, ao estabelecer a igualdade de todos perante a lei, sem distinção de qualquer natureza, abrangendo as diferenças quanto ao sexo, orientação sexual e identidade de gênero. A Declaração de Direitos Humanos consagra que as pessoas nascem livres e iguais em dignidade e direitos, sem distinção de sexo (ONU/1948).

Em 2014, o Tribunal Regional do Trabalho da 23 $3^{\text {a }}$ Região julgou uma Ação em que uma trabalhadora pedia indenização por danos morais por ter se sentido transgredida ao ter de trocar de uniforme no mesmo vestuário que uma pessoa transexual que trabalhava no também local. A empresa se defendeu argumentando que estava observando normas e que a funcionária estaria discriminando a colega. A Juíza, relatora do processo, argumentou no indeferimento do pedido de indenização que não seria razoável "que um trabalhador transgênero, com sentimentos e aparência femininos, fosse compelido a utilizar vestiário masculino". Segundo a magistrada, "desconfortos advindos de convicções sociais e religiosas não podem configurar dano moral". Na mesma direção da decisão, o parecer de ato normativo do CNJ prediz que, nas sedes judiciais e administrativas dos órgãos do Poder Judiciário, necessita ser garantido o uso de vestiários, banheiros e outros espaços separados por gênero, quando houver, de conformidade com a identidade de gênero do indivíduo. (AGENCIA CNJ, 2016)

O tribunal se alinhou ao direito à liberdade de gênero e autodeterminação sexual, reconhecendo a proteção legal à trabalhadora transexual. É inaceitável a intolerância que fomente a desigualdade em razão da identidade de gênero. Aliás, não é outra a indicação dos Princípios de Yogyakarta ao consagrar que

[...] todas as pessoas têm o direito de desfrutar de todos os direitos humanos livres de discriminação por sua orientação sexual ou identidade de gênero. Todos e todas têm direito à igualdade perante a lei e à proteção da lei sem qualquer discriminação, seja ou não também afetado o gozo de outro direito humano. (YOGYAKARTA, 2017) 
A não aceitação por parte da pessoa cisgênero, pode impedir o crescimento pessoal, o bem-estar, o conforto, a segurança da pessoa trans. (VIEIRA; CARMO GOMES, 2017) Ademais, a dignidade da pessoa humana é um dos fundamentos da República, devendo o Estado potencializar a sua proteção e promoção, garantindo a diversidade.

\section{Considerações finais}

Não pretendeu-se, com este trabalho, exaurir este riquíssimo tema, mas provocar algumas reflexões acerca das possibilidades que poderão ser empreendidas para a resolução de problemas que atinem às pessoas trans em suas relações, tais como, alterações do nome e gênero de crianças e adolescentes, mudança do nome dos pais nos registros dos filhos maiores ou menores, direito ou não ao esquecimento no que concerne a não informação ao futuro cônjuge acerca do estado anterior, uso de banheiros e vestiários de acordo com a identidade de gênero, dentre outros.

Assim, ponderou o Supremo Tribunal Federal que cabe ao Estado o reconhecimento, sem impor condições para a alteração dos assentos no registro público, a qual depende apenas da livre manifestação de vontade da pessoa que visa expressar sua identidade de gênero, admitindo aos transgêneros, que assim o desejarem, independente da cirurgia de transgenitalização, ou da realização de tratamentos hormonais ou patologizantes, o direito à substituição de prenome e menção do sexo diretamente no registro civil, independentemente de cirurgia de transgenitalização. Nenhuma identidade pode ser considerada patológica.

Considerou-se que, identidade nada tem a ver com genitalidade. A identidade de gênero é manifestação da personalidade da pessoa humana e, como tal, cumpre ao Estado apenas o papel de reconhecê-la, nunca de constituí-la. O vocábulo mulher, por exemplo, pode se referir tanto ao sexo feminino, quanto ao gênero feminino, uma vez que alude-se aos atributos culturais, sociais e políticos cominados a homens e mulheres e não às distinções biológicas.

Destarte, faz-se necessária a realização de políticas públicas mais eficazes de combate ao preconceito e à discriminação das pessoas trans, protegendo-as da violência e garantindo direito à igualdade de oportunidades. 


\section{Referências bibliográficas}

AGENCIA CNJ. Tribunal de Mato Grosso reconhece uso do nome social em processo. Disponível em: http://www.cnj.jus.br/noticias/cnj/83038-tribunal-reconhece-uso-do-nomesocial-em-processo. Edição de 18 ago 2016.

ALVES, Felipe Dalenogare; GOFAS, Faena Gall. O transexual e o direito ao esquecimento no ciberespaço após a mudança de gênero: por um tratamento compatível com o constitucionalismo contemporâneo brasileiro, de promoção aos direitos fundamentais e garantia à diversidade. In: Revista Publicum, Rio de Janeiro, v. 3, n. 1, 2017, p. 78-99, p.97.

BENEDETTI, Marcos Renato. Toda feita: o corpo e o gênero das travestis. Rio de Janeiro: Garamond; 2005.

BRASIL. Alistamento Militar. Disponível em http://www.brasil.gov.br/defesa-eseguranca/2014/02/tire-suas-duvidas-sobre-o-alistamento-militar”. Acesso em: 29 abr 2018.

, Decreto n. 8727. Dispõe sobre o uso do nome social e o reconhecimento da identidade de gênero de pessoas travestis e transexuais no âmbito da administração pública federal direta, autárquica e fundacional. Publicado no DOU de 29.4.2016.

, Constituição Federal. Vade Mecum. 15 ed. São Paulo: Saraiva, 2013. , . Estatuto da Criança e do Adolescente. Vade Mecum. 15 ed. São Paulo: Saraiva, 2013.

,. Portal Brasil. Publicado: 30 Jan 2018

, LEI No 4.375, DE 17 DE AGOSTO DE 1964. Lei do Serviço Militar. Publicado no DOU de 3 set 1964.

BUTLER, Judith P. Problemas de gênero. Feminismo e subversão da identidade.

Tradução Renato Aguiar, 11ed. Rio de Janeiro: Civilização Brasileira, 2016, p.26. 
CANOSA, Ana Cristina. Sexualidade na Visão Sistêmica. Payá e cols. Intercâmbio das Psicoterapias. Como cada abordagem compreende os transtornos psiquiátricos. $2 \mathrm{ed}$. São Paulo: Editora Roca, 2017.

CNJ - Conselho Nacional de Justiça, Provimento n.73, de 28 de junho de 2018. Dispõe sobre a averbação da alteração do prenome e do gênero nos assentos de nascimento e casamento de pessoa transgênero no Registro Civil das Pessoas Naturais (RCPN).

DIAS, Maria Berenice. De quem sou filho. Disponível em:

$<$ http://www.ibdfam.org.br/artigos/904/De+quem+sou+filho\%3F > . Acesso em: 25 abr. 2017A.

FACHIN, Luiz Edson. Da paternidade: relação biológica e afetiva. Belo Horizonte: Del Rey, 1996, p. 98.

IBDFAM. Estatuto das Famílias. Porto Alegre: Magister, 2007, p. 23.

, Sugere padronização do procedimento de alteração de registro civil de transexuais. Assessoria de Comunicação. 11 abr 2018. Pedido de Providências 000207779.2018.2.00.0000.

MACHADO, W.L.; BANDEIRA, D.R. Bem-estar psicológico: definição, avaliação e principais correlatos. Estudos de Psicologia I, Campinas I 29(4) I 587-595 I outubro dezembro 2012, p. 587-595.

MENINO consegue na Justiça mudar para gênero feminino e trocar de nome. Disponível em: $<$ http://g1.globo.com/mato-grosso/noticia/2016/01/menino-consegue-na-justica-mudar-paragenero-feminino-e-trocar-de-nome.html> Acesso em: 20 ago. 2016.

ONU. Assembleia Geral, 1948.

PLENÁRIO STF. AÇÃO DIRETA DE INCONSTITUCIONALIDADE 4.275. DISTRITO FEDERAL. Relator: ministro Celso de Mello. Julgamento: 01. Mar. 2018. 
ROCON, PC; SODRÉ, F; ZAMBONI, J; RODRIGUES, A; ROSEIRO, MCFB. What trans people expect of the Brazilian National Health System?. Interface (Botucatu). 2018; 22(64):43-53.

SÁ, M.F.F.; NAVES, B.T.O. Bioética e biodireito. 4ed. Belo Horizonte: Del Rey, 2018.

SANCHES, Helen Crystine Corrêa; VERONESE, Josiane Rose Petry. Dos Filhos de Criação à Filiação Socioafetiva. Editora Lumen Juris: Rio de Janeiro, 2012, p. 61.

SANTOS, Ailton. Transexualidade e travestilidade: conjunções e disjunções.

Transexualidades. Um olhar multidisciplinar. Maria Thereza Ávila Dantas Coelho e Liliana Lopes Pedral Sampaio organizadoras. Salvador: Edufba, 2014, p. 79-99

SENADO FEDERAL. PROJETO DE LEI DO SENADO n ${ }^{\circ} 134$ de 2018. Institui o Estatuto da Diversidade Sexual e de Gênero. Relator: Ataídes de Oliveira. Disponível em: < https://www25.senado.leg.br/web/atividade/materias/-/materia/132701/pdf $>$ Acesso em: 30 abr 2018.

STF reconhece a transgêneros possibilidade de alteração de registro civil sem mudança de sexo. Disponível em: <http://www.stf.jus.br/portal/cms/verNoticia Detalhe.asp?idConteudo=371085 >Acesso em: 27 abr 2018.

VIEIRA, Denise Leite; PAYA, Roberta. Família, diversidade e transgeneridade. In: Famílias, Psicologia e Direito. Tereza Rodrigues Vieira, Valéria Silva Galdino Cardin e Barbara Bieber orgs. Brasília: Zakarewicz Editora, 2017, p. 327-340.

VIEIRA, Tereza Rodrigues. Transexual menor de idade e adequação do nome. Revista Jurídica Consulex, n. 402, outubro de 2013, p.22-24.

VIEIRA, Tereza Rodrigues; CARMO GOMES, Luiz Geraldo. A família trans e o direito. In: Famílias, Psicologia e Direito. Tereza Rodrigues Vieira, Valéria Silva Galdino Cardin e Barbara Bieber orgs. Brasília: Zakarewicz Editora, 2017, p. 341-354. 
YOGYAKARTA PRINCIPLES Indonesia, in November 2006. The Principles were supplemented in 2017, expanding to include new grounds of gender expression and sex characteristics, and a number of new principles. Disponível em: $<$ http://yogyakartaprinciples.org/principles-en/yp10/> Acesso em: 21 mar 2018. 


\title{
RESPONSABILIDADE CIVIL DOS MÉDICOS NOS CASOS DE CIRURGIA DE REDESIGNAÇÃO DE SEXO DOS TRANSEXUAIS
}

\author{
Cintia Rosa Pereira de Lima \\ Faculdade de Direito de Ribeirão Preto da Universidade de São Paulo \\ Emanuele Pezati Franco de Moraes \\ Faculdade de Direito de Ribeirão Preto da Universidade de São Paulo
}

\begin{abstract}
Resumo
O presente artigo pretende destacar os efeitos jurídicos das cirurgias de transgenitalização, pois não há lei específica, apenas a Resolução n. 1.955/2010 do Conselho Federal de Medicina. Nesse sentido, há divergências doutrinárias e jurisprudenciais que serão levantadas nesse trabalho, para oferecer soluções tendo em vista o alcance da dignidade da pessoa humana. No plano de pesquisa, o material utilizado foram livros, artigos e julgados, utilizando-se dos métodos indutivos e dedutivos na explanação dos resultados obtidos. O objeto central é a análise quanto à responsabilidade civil do Hospital, seja público ou privado, assegurado o direito de regresso ao médico.
\end{abstract}

Palavras-chave: Resolução n. 1.955/2010, cirurgias de transgenitalização, obrigação de meio, obrigação de resultado

\section{Abstract/Resumen/Résumé}

This paper highlights the legal effects of the sex redesignation surgeries, given the fact that there is no specific law, but only the Federal Council of Medicine's Resolution n. 1955/2010. So, there are divergences within the doctrine and Courts, that will be pointed out, in order to offer some solutions to enforce the human dignity principle. For the present research, it was used books, papers and cases, and the methodology applied were the inductive and deductive methods in the explanation of its results. The central object is the Hospital's liability, public or private, ensured the right of recourse against doctor.

Keywords/Palabras-claves/Mots-clés: Resolution n. 1955/2010, sex redesignation surgeries, means' obligation, result's obligation. 


\section{Introdução}

Sexo, gênero e sexualidade são conceitos diferentes, considerados entre os direitos fundamentais de primeira geração. Tais direitos são vinculados externamente aos direitos humanos e internamente ao princípio constitucional de dignidade da pessoa humana (art. $1^{\circ}$, inc. III Constituição Federal do Brasil - CF/88), margeados pelo direito da personalidade, intimidade, liberdade (art. $5^{\circ}$, caput e inc. X CF/88). A divisão dos direitos fundamentais em gerações decorre da socialização do Estado contemporâneo, ampliando subjetiva e objetivamente o Direito.

O reconhecimento da pessoa humana baseada no modelo, ultrapassado, binário que compreendia, em tom excludente, somente o masculino e feminino como identidade de gênero e sexo, não mais alcança a realidade social e a velocidade das transformações sociais.

O respeito à pluralidade de gênero, na visão de Melo e Azevedo, tem "encorajado a revelação de novos modos particulares de identificação do gênero a que pertence cada um, aí se incluindo a neutralidade de gênero, como já admitem alguns países europeus”. (MELO e AZEVEDO, 2016, p. 218)

Atento a temática 25 países, incluindo o Brasil, em 2006 se reuniram na Universidade de Gadjah Mada situada na cidade de Yogyakarta, Indonésia. Na oportunidade, os participantes produziram e adotaram, por unanimidade, os "Princípios de Yogyakarta: Princípios sobre a aplicação da legislação internacional de direitos humanos em relação à orientação sexual e identidade de gênero".

Considerado um Tratado que versa sobre direitos humanos, é de observância obrigatória e passa a vigorar como um direito e garantia individual nos termos do $\S 3^{\circ}$ do art. $5^{\circ}$ da $\mathrm{CF} / 88$, assegurando-se, portanto, o direito às diferenças na medida em que se reconhece que todas as pessoas, "nascidas livres e iguais em dignidade e prerrogativas, possam usufruir de seus direitos, que são natos e preciosos”. (YOGYAKARTA, 2007, pp. 6 - 7)

A interiorização dos Princípios de Yogyakarta pelo Brasil, dá-se, outrossim pela tutela dos direitos da personalidade, especificamente dos transexuais. Direitos de personalidade são considerados como um conjunto de atributos humanos, morais e psicológicos, que estabelecem respeito à dignidade do indivíduo, razão pela qual, qualquer tratamento discriminatório deve ser prevenido, não sendo possível, que, ao menos, seja compensado, indenizado. Denomina-se bens de personalidade a liberdade, a vida, a imagem, a honra, o nome. (LIMA NETO, 2008, p. $79-81)$ 
O direito à identidade pessoal é intrínseco à identidade de gênero ou neurodiscordância de gênero. Rubens Limongi França (1971, p. 404) ensina que "é o direito que tem a pessoa de ser conhecida como aquela que é, e de não ser confundida com outrem”. Para Jacques Robert (2009, p. 336), os transexuais afirmam-se enquanto cidadãos, incluindo-se no âmbito do direito da personalidade, à identidade pessoal, assumindo seu status e requerendo respaldo Estatal para usufrui-lo.

A proteção do transexual está fundada no direito à intimidade, quando este assume sua situação, poderá, inclusive, permanecer na ambiguidade de gênero, ocasionando uma dupla vida, conflitiva e angustiante. A opção de gênero, conflitiva ou não, é direito próprio da pessoa. (ARAUJO, 2000, p. 69)

No Brasil, desde 1997 é permitido a realização da cirurgia de transgenitalização, atualmente esses procedimentos estão regulados na Resolução $\mathrm{n}^{\mathrm{o}}$ 1.955/2010, do Conselho Federal de Medicina (CRM), contudo, por se tratar de diretriz regulamentar medica a resolução não tem o condão de abarcar previsão legal sobre os efeitos jurídicos do procedimento médico. A lacuna normativa contribui para a invisibilidade e exclusão dos transexuais. (GONÇALVES, 2012, p. 04)

Diante desse contexto, esse artigo tem por objetivo destacar o grave prejuízo à efetivação dos direitos de personalidade dos transexuais em função da omissão do Legislador; enfatizar os direitos fundamentais dos transexuais seja submetendo-se às cirurgias de redesignação de sexo, seja aos tratamentos hormonais e o consequente reconhecimento em sua plenitude dessa situação jurídica; analisar a responsabilidade do Hospital, público ou privado, nos quais tais procedimentos são realizados, e a ação regressiva face ao médico. Ao final, pretende-se demonstrar a necessária atuação do Legislador para garantir esses direitos de personalidade aos transexuais especificamente a fim de minimizar e, quiçá, eliminar os entraves e inseguranças jurídicas.

Portanto, justifica-se essa pesquisa, pois o árduo tema relacionado à responsabilidade civil da equipe multidisciplinar que conduz o tratamento do paciente. Isto porque se deve distinguir entre obrigação de meio (quanto aos aspectos clínicos e funcionais dos procedimentos cirúrgicos) e obrigação de resultado (quanto ao aspecto plástico das cirurgias de redesignação de sexo) para que se possa aferir a culpa dos médicos. Em qualquer hipótese, eles devem agir com extrema cautela e zelo em todos os protocolos médicos, sejam eles psicoterapêuticos, prescrição e utilização de hormônios ou mesmo a indicação de procedimentos cirúrgicos como parte da adequação do gênero do paciente ao sexo fisiológico. 
Se por um lado, houve avanços para que a cirurgia pudesse ser realizada com segurança, afastando-a do campo da estrita ilegalidade, por outro, a diretriz do CRM 1.955/2010 encontra eco em um tradicionalismo por tratar uma dissonância entre identidade de gênero e sexo biológico como uma doença. Schreiber segue o entendimento:

Não se está a defender que a/o transexual não tenha o devido acompanhamento psicológico e médico, contudo, soa como um anacronismo histórico assentar que discussões de gênero e sexualidade ainda sejam tratadas no rol de doenças. (SCHREIBER, 2013, p. 44)

Ademais, no caso dos transexuais, apenas as intervenções médicas para adequação fisionômica ao gênero não se fizeram suficiente a plenitude da dignidade da pessoa humana do transexual, sendo condição sine qua non o reconhecimento do outro, competindo ao ordenamento jurídico dispor de mecanismos que garanta ao transexual a seguridade de não segregação social. (SOUZA E VIEIRA, 2016, p. 598)

A pressão de adequação social sofrida pelos transexuais impede que possuam capacidade de gozo de seus direitos da personalidade como um todo, tal sofrimento tende a piorar quando se apresentam por um nome divergente da forma com que se aparentam, face a lacuna legal e a mora do judiciário. (ALVES E LIMA, 2016, p. 114)

Nessa pesquisa, utiliza-se os métodos indutivos e dedutivos na explanação dos resultados. Em outras palavras, parte-se do geral, que é a tutela dos direitos de personalidade para demonstrar que, no caso específico dos transexuais, pode ser aplicado. Ademais, parte-se do específico que é a norma deontológica do CRM sobre os tratamentos de redesignação sexual para que se possa extrair regras gerais que sirvam de inspiração ao Legislador.

\section{Distinção entre sexo, gênero e orientação sexual}

Para a completa compreensão do tema, deve-se saber a distinção entre sexo, gênero e orientação sexual. Assim, serão abordados esses conceitos a fim de que possa instruir a situação dos transexuais.

\subsection{Tipos de sexo}

A etimologia da palavra "sexo", originária do latim sexu. A identificação primária do sexo biológico nos seres humanos, é de responsabilidade profissional do médico, quando do nascimento de uma criança, ou seja, compete a ele, inicialmente, a caracterização do recém- 
nascido como sendo homem ou mulher, definindo o sexo que constará na certidão de nascimento.

Nesse passo, a certidão de nascimento de uma pessoa é determinada por diretrizes médicas sobre o sexo de um recém-nascido, partindo de um conceito biológico, identificado no início da vida, enquanto o gênero segue um conceito social (art. 54, $2^{\circ}$, Lei n. 6.015/73).

O sexo, inicialmente, era identificado nos seres humanos apenas pela característica das estruturas externas das genitálias, as quais designavam também o seu gênero. Ocorre que este protocolo medico demonstrou-se ultrapassado e ineficaz, isso porque o avanço da pesquisa médica revelou a existência de indivíduos intersexuados.

Estes indivíduos intersexuados e transexuais abalaram a diretriz binária de masculino e feminino até então utilizada no protocolo médico, tornando-se ineficaz a simples análise das estruturas externas das genitálias para identificar o sexo da pessoa. (SOUZA e VIEIRA, 2016, p. 589)

Em um segundo momento, a identificação do sexo do recém-nascido passou a ser realizada pelos médicos com ajuda da genética, analisando os cromossomos, sendo que quando visto os cromossomos XX era identificado o sexo feminino e quando aferido os cromossomos XY era identificado o sexo masculino (QUAGLIA, 1980, p.134). Entretanto, este protocolo médico foi abalado pelas descobertas de imprecisões genéticas como a monossomia, também chamada de Síndrome de Turner, que ocorre quando há apenas um X no par de cromossomos sexuais, ou, nos casos de trissomia X, também chamada de Síndrome do triplo X ou Síndrome de Klinefelter, que ocorre quando o par de cromossomo sexual conta com um cromossomo a mais, ficando com três cromossomos X. A embriologia e a fisiologia molecular ajudaram a responder ao novo dilema destacando os marcadores hormonais e utilizando-se da diferenciação fisiológica entre ovários e testículos para determinação do sexo, mas, novamente, a presença dos intersexuais questionou esse binarismo sexual (CERQUEIRA. E. K., VERRESCHI. I.T.D.N in SOUZA e VIEIRA, 2016, p. 590).

Em face destas dificuldades de identificação sexual, segundo o Código de Ética Médica: Resolução CFM no 1931/2009¹, é de dever do profissional a correta consignação do sexo biológico, sendo obrigatório ao médico valer-se de todos os meios técnicos a fim de oferecer um diagnóstico adequado ao paciente, observando a eventual existência de intersexualidade. (CUNHA, 2015, p. 248).

\footnotetext{
${ }^{1}$ RELAÇÃO COM PACIENTES E FAMILIARES É vedado ao médico: (...) Art. 32. Deixar de usar todos os meios disponíveis de diagnóstico e tratamento, cientificamente reconhecidos e a seu alcance, em favor do paciente.
} 
A medicina adota fases para diferenciar o sexo biológico. A primeira delas é a determinação do sexo biológico cromossômico, pois os cromossomos são os responsáveis pela formação das gônodas em testículos ou ovários, que formaram os genitais internos e externos, e produzirão os hormônios que completam o fenótipo sexual. Assim ensina a literatura médica:

NOS SERES HUMANOS E NA MAIORIA DOS MAMÍFEROS, os processos de determinação e diferenciação sexuais estão intrinsecamente associados à presença ou à ausência do cromossomo Y no cariótipo. O evento pivô na determinação sexual é a especialização das gônadas; as demais diferenças entre os sexos são efeitos secundários devidos aos hormônios por elas produzidos. O processo como um todo é classicamente dividido em quatro etapas: a determinação do sexo cromossômico, que é estabelecida na fertilização; a diferenciação das gônadas em testículos ou em ovários; a diferenciação dos genitais internos e externos masculinos ou femininos a partir de estruturas indiferenciadas presentes no embrião, que é dependente da presença ou ausência de testículos; e a diferenciação sexual secundária, que é a resposta de vários tecidos aos hormônios produzidos pelas gônadas para completar o fenótipo sexual. Portanto, a expressão "determinação sexual" relaciona-se principalmente aos processos que levam à função testicular geral; por outro lado, a expressão "diferenciação sexual" refere-se às ações hormonais específicas que levam ao fenótipo sexual de cada indivíduo. Essas contribuem para o desenvolvimento dos genitais externos e internos, bem como para a maturação sexual durante a puberdade. (g.n.) (MELLO, ASSUMPÇÃO E HACKEL, 2014, p. 14)

A definição de erro médico pode ser descrita como ação ou omissão do profissional, no exercício medico, que cause danos à saúde do paciente, somente podendo ser imputado comprovado o nexo de causalidade entre falha do médico e o mau resultado do diagnóstico.

(SALAMACHA, 2013, p. 101)

\subsection{Orientação sexual e gênero}

Os princípios de Yogyakarta instruem que todos nascem livres e iguais em dignidade e direito. "A orientação sexual ${ }^{2}$ e a identidade de gênero ${ }^{3}$ são essenciais para a dignidade e humanidade de cada pessoa e não devem ser motivo de discriminação ou abuso." (YOGYAKARTA, 2007, p. 6)

A orientação sexual vê-se pela indicação do(s) gênero(s) em relação a qual a pessoa se sente emocional e fisicamente atraída. Dada a complexidade dos impulsos da mente humana, a orientação sexual pode ser heterossexual (atração por outro gênero), homossexual (atração pelo

\footnotetext{
${ }^{2}$ Compreendemos orientação sexual como uma referência à capacidade de cada pessoa de ter uma profunda atração emocional, afetiva ou sexual por indivíduos de gênero diferente, do mesmo gênero ou de mais de um gênero, assim como ter relações íntimas e sexuais com essas pessoas.

${ }^{3}$ Compreendemos identidade de gênero a profundamente sentida experiência interna e individual do gênero de cada pessoa, que pode ou não corresponder ao sexo atribuído no nascimento, incluindo o senso pessoal do corpo (que pode envolver, por livre escolha, modificação da aparência ou função corporal por meios médicos, cirúrgicos ou outros) e outras expressões de gênero, inclusive vestimenta, modo de falar e maneirismos.
} 
mesmo gênero), bissexual (atração pelos dois gêneros), assexual (não atração sexual e/ou afetiva por nenhum gênero) ou pansexual (atração por todos os gêneros). (MELO e AZEVEDO, 2016, p. 220)

A orientação sexual está relacionada às características psicológicas, como o indivíduo em relação ao outro. A identidade de gênero difere da orientação sexual, porque essa última não se trata de como a pessoa se sente em relação ao outro, mas sim em relação a si própria, em como a pessoa se identifica perante a sociedade.

Vieira ensina que a identidade de gênero é uma condição em que a pessoa se identifica com o gênero oposto ao sexo biológico, e considera isso como desarmônico e profundamente desconfortante. É um desejo de viver e de ser aceito enquanto pessoa do sexo oposto. Esse sentimento pode estar acompanhado de mal-estar ou de inadaptação ao seu sexo anatômico. Nesses casos, a indicação médica pode ser a intervenção cirurgia e tratamentos hormonais. (VIEIRA, 2012, p. 158)

A definição do gênero não se restringe à identificação medico-cientifica dos cromossomos, conformação genital ou identificação fisiológica, mas sim à complexidade do ser humano, sendo o gênero identificado por meio da autopercepção e da expressão pessoal em sociedade. (SOUZA e VIEIRA, 2016, p. 592)

Quando o gênero ao qual a pessoa se identifica é o mesmo atribuído na certidão de nascimento, tomando-se por base o sexo biológico, diz-se cisgêneros; mas quando a pessoa não identifica o seu gênero ao que lhe foi atribuído como seu sexo biológico, diz-se transgênero (SOUZA e VIEIRA, 2016, pg. 594).

Nesse passo, os transexuais são pessoas que, biologicamente, pertencem a um sexo definido após seu nascimento pelas características físico-biológicas, contudo, psicologicamente pertencem e identificam-se a outro gênero, comportando-se segundo este. Esta divergência entre seu gênero e seu sexo implicou ao Estado o dever de garantir à dignidade da pessoa humana, assegurando seus direitos da personalidade quanto à redesignação de sexo e o pleno reconhecimento jurídico dessa situação.

A história aponta para muitos exemplos de transexuais, como Henrique III da França, em 1977, que compareceu junto aos deputados com vestimentas femininas. François Timoléon de Abade de Choisy, embaixador de Luiz XIV em Sião, que foi educado como mulher, sendo biologicamente do sexo masculino. Charles de Beaumont, Chevalier d'Eon, viveu 49 anos como homem e outros 34 anos com vestimentas femininas, usado por Luiz XV em missões secretas na Rússia e na Inglaterra, vestindo-se de mulher. (DINIZ, 2011, p. 218) 


\section{Direitos de personalidade dos transexuais à luz dos princípios basilares da bioética}

O princípio da dignidade da pessoa humana, pautado pela Declaração Universal dos Direitos do Homem de $1948^{4}$, é consagrado no art. $1^{\text {o }}$, inc. III da CF/88. Este princípio impõe que o ser humano seja o ponto de referência de todo o sistema normativo. (LAFER, 2007, p. 57)

A bioética não admite qualquer intervenção no corpo humano que não redunde ao bem do indivíduo, sendo este sempre o fim, nunca o meio, analisa o homem como pessoa ou como um “eu”, personalíssimo, conferindo valor fundamental à vida e à dignidade humana. (DINIZ, 2011, p. 30)

Alguns anos após a consolidação da Declaração Universal dos Direitos do Homem, Van Rensselaer Potter, em 1971, trouxe a expressão "bioética". A ideia proposta para a consolidação da bioética era de lançar uma nova disciplina que alcançasse as pesquisas cientificas de forma a assegurá-las como produção humanista, visando a acompanhar o desenvolvimento cientifico em atenção a ética, inicialmente, ecológica.

A bioética desenvolveu-se, frente ao princípio da dignidade da pessoa humana, moderando o potencial agressivo, desagregador e destrutivo que controlassem as práticas do desenvolvimento da pesquisa cientifica com humanos. A bioética tem o condão basal de oferecer critérios objetivos para conflitos entre valores da ciência e humanidades, impedindo que o avanço científico acabe por coisificar o ser humano.

Muito se discute sobre a previsão especifica de um direito geral da personalidade, como o art. 70o, do Código Civil Português. (MENEZES CORDEIRO, 2009, p. 102). No Brasil o direito da personalidade tem seu fundamento localizado no princípio constitucional da dignidade da pessoa humana. (GONÇAVES, 2012, pp. 148-149)

Os direitos de personalidade abarcam a identidade sexual, nesse passo, é possível afirmar que a pessoa maior, capaz e que consente, pode dispor de seu próprio corpo para que possa se submeter à cirurgia de redesignação de sexo? O transexual enfrenta a rejeição da sociedade e da família, a dificuldade de absorção ao mercado de trabalho, a marginalização social ao apresentar seu documento de identidade com um sexo que lhe é imposto e dissonante

\footnotetext{
${ }^{4}$ O preambulo desta declaração traz que: "a ASSEMBLÉIA GERAL, proclama a presente DECLARAÇÃO UNIVERSAL DOS DIREITOS HUMANOS como o ideal comum a ser atingido por Declaração, se esforce, através do ensino e da educação, por promover o respeito a esses direitos e liberdades, e, pela adoção de medidas progressivas de caráter nacional e internacional, por assegurar o seu reconhecimento e a sua observância universal e efetiva, tanto entre os povos dos próprios Estados-Membros, quanto entre os povos dos territórios sob sua jurisdição." todos os povos e todas as nações, com o objetivo de que cada indivíduo e cada órgão da sociedade, tendo sempre em mente esta
} 
ao que realmente sente ser. Mesmo, em regra, com QI superior à média, é grande a taxa de desemprego do transexual, diante da inadequação do registro civil a sua aparência. (DINIZ, 2011, p. 318)

Ainda que não tenha sido expressamente previsto, o direito ao transexual de ter tratamento médico para adequar seu sexo ao seu gênero deve ser tratado como um direito de personalidade a fim de que se possa efetivar o princípio da dignidade da pessoa humana.

O tratamento médico aos transexuais, inicialmente, era caracterizado como experimental e de risco, hoje são procedimentos cuja realização é mais segura. Em todo caso, qualquer procedimento médico experimental deve seguir o princípio da autonomia, derivado do Termo de Consentimento Livre e Esclarecido dos sujeitos.

$\mathrm{O}$ respeito à dignidade e autonomia da pessoa deve ser respeitado nas pesquisas medicas, além da proteção de sua vulnerabilidade. Um dos requisitos para cumprimento dessa premissa é a exigência do consentimento livre e esclarecido à pessoa ou aos seus representantes legais, e só em casos excepcionais, devidamente justificado e documentando, pode se realizar procedimentos sem a documentação necessária. (BARBOZA, 2006, p. 221)

Maria Helena Diniz apresenta o transexual sendo portador de uma anomalia surgida no desenvolvimento da estrutura nervo central, ainda em estado embrionário, sem alterações intelectuais e profissionais, sofrendo de uma impregnação hormonal no hipotálamo, pelo hormônio contrário, nos últimos dias de vida fetal ou nas primeiras semanas de vida. Seria licito ao paciente a intervenção cirúrgica para mudar de sexo ou seria desnecessária em face da vedação constitucional a discriminação social e profissional? (DINIZ, 2011, p. 317-319)

\section{Cirurgias de redesignação de sexo ("transgenitalização")}

Em 1971 o cirurgião plástico Roberto Farina realizou a primeira cirurgia de redesignação de gênero no país em Waldir Nogueira, que passou a se chamar Waldirene Nogueira. Entretanto, diante da não regulação do procedimento seja pelo Direito seja pelo CRM, o médico foi condenado, em 1978, a dois anos de reclusão sob alegação de ter infringido o disposto no art. $129, \S 2^{\circ}$, III ${ }^{5}$ do Código Penal Brasileiro. Em sede de apelação, a $5^{\text {a }}$ Câmara do Tribunal de Alçada de São Paulo, por maioria, em 06 de novembro de 1979, deu provimento ao apelo, absolvendo o médico, sob o argumento que não houve dolo na conduta, pois o médico

\footnotetext{
${ }^{5}$ Lesão corporal - Art. 129. Ofender a integridade corporal ou a saúde de outrem: $\S 2^{\circ}$ Se resulta: III - perda ou inutilização do membro, sentido ou função; Pena - reclusão, de dois a oito anos.
} 
pretendia "curá-lo ou reduzir seu sofrimento físico ou mental. Semelhante cirurgia não é vedada pela lei, nem pelo Código de Ética Medica”. (VIEIRA, 2012, p. 174)

$\mathrm{O}$ direito de personalidade de integridade física e direito ao corpo e às partes do corpo não é absoluto, nos termos do art. 13 do $\mathrm{CC} / 02$, pois por determinação médica, admite-se a relativa disposição sobre o corpo, desde que em benefício da saúde.

A cirurgia de redesignação de sexo surge como uma possível solução para o transexual, na tentativa de integração social, devendo ser apoiada e incentivada pelo Estado, seguindo as orientações medicas sobre o procedimento, hoje disciplinado pelo Conselho Federal de Medicina - CFM. Deve o profissional, junto a uma equipe multidisciplinar, oferecer ao paciente uma redução no grau de angustia, não sendo possível falar em dolo médico. (ARAUJO, 2000, pp. 111 - 112)

Nos Estados Unidos, o transexual, livremente, poderá escolher passar pelo procedimento cirúrgico, desde de que o consentimento assistido seja acompanhado de um advogado, que acompanhará pessoalmente a declaração do paciente, eximindo o médico de responsabilidades posteriores por complicações futuras. (DINIZ, 2011, p. 326)

O parecer do Conselho Federal de Medicina - CFM n ${ }^{0}$ 20/10, aborda o tema elucubrando que o start da discussão sobre a regularização ética da viabilidade de realização da cirurgia foi dado, em 1994, pelo Conselheiro Pablo Magalhães Chacel, que, orientou o Conselho Regional de Medicina do Distrito Federal - CRM-DF no sentido de que a cirurgia transexual era legal e ética. Frente a polemica gerada, o CFM designou uma comissão formada pelos conselheiros Júlio Cezar Meirelles e Lúcio Mario da Cruz Bulhões para discutir o tema. Em 09 de maio de 1997 foi aprovado o parecer $n^{\circ}$ 39/97, deste parecer, foi então normatizada e aprovada a Resolução CFM n $1.482 / 1997$, primeira Resolução do CFM que tratou do tema. $\left(\mathrm{CFM}\right.$, parecer $\left.\mathrm{n}^{\mathrm{o}} 20,2010\right)$

Ato continuo, o Conselho Federal de Medicina autorizou a realização da cirurgia constituindo o Parecer CFM n ${ }^{\circ}$ 1487/1997:

considerando o paciente transexual titular de desvio psicológico permanente de identidade sexual, com rejeição de seu fenótipo e tendências à automutilação e/ou autoextermínio; considerando não constituir crime previsto no art. 129 do Código Penal, visto que o procedimento tem caráter terapêutico; considerando haver viabilidade técnica para cirurgias de redesignação de sexo, neocolpovulvoplastia e neofaloplastia; considerando o disposto no Art. 199 da CF/88 que trata da remoção de órgãos, tecidos e substancias humanas para fins de transplante, pesquisa e tratamento, sendo o procedimento cirúrgico de redesignação parte do tratamento do transexual; considerando que não há vedação legal do procedimento cirúrgico em tela; considerando que o intuito da licitude cirurgia foi de fomentar o aperfeiçoamento da técnica. 
Diante dos avanços medicinais que puderam ocorrer frente ao Parecer do CFM, cumprindo com a última consideração trazida na resolução, de aperfeiçoamento da técnica, o primeiro regulamento foi substituído pela Resolução CFM n ${ }^{\circ}$. 1.652/2002, constando nas considerações que:

\begin{abstract}
CONSIDERANDO o estágio atual dos procedimentos de seleção e tratamento dos casos de transexualismo, com evolução decorrente dos critérios estabelecidos na Resolução CFM no. 14.82/907 e do trabalho das instituições ali previstas; CONSIDERANDO o bom resultado cirúrgico, tanto do ponto de vista estético como funcional, das neocolpovulvoplastias nos casos com indicação precisa de transformação o fenótipo masculino para feminino; CONSIDERANDO as dificuldades técnicas ainda presentes para a obtenção de bom resultado tanto no aspecto estético como funcional das neofaloplastias, mesmo nos casos com boa indicação de transformação do fenótipo feminino para masculino; CONSIDERANDO que o diagnóstico, a indicação, as terapêuticas prévias, as cirurgias e o prolongado acompanhamento pós-operatório são atos médicos em sua essência" (CFM, resolução $\left.\mathrm{n}^{\circ} .1 .652,2002\right)$
\end{abstract}

A grande mudança do texto regulamentário deu-se com a exclusão do termo "a título experimental" para a cirurgia de neocolpovulvoplastia (alteração das características externas do sexo masculino para feminino), posto que, tamanho sucesso alcançado no procedimento, não coube mais a expressão experimental do procedimento, consolidado como de sucesso perante a medicina.

O impacto desta mudança foi sentido, principalmente, pelo Sistema Único de Saúde, que pode incluir tal procedimento na Tabela de Procedimentos do SIH/SUS, via portaria $\mathrm{n}^{\circ}$ 1.707, publicada em 2008. Assim, os transexuais do sexo masculinos puderam se valer do Sistema Único de Saúde para garantir seu direito ao tratamento completo, incluindo a cirurgia de redesignação de sexo. Entretanto, o mesmo não se deu aos transexuais do sexo feminino, pois a Resolução de 2002 manteve a neofaloplastia e/ou procedimentos complementares sobre gônodas e caracteres sexuais secundários em caráter experimental.

Atento ao cumprimento integral do preceito de não discriminação e acesso à saúde pública, a promotoria de justiça do Ministério Público do Distrito Federal encaminhou ao presidente do CFM uma consulta, assinada por outras 17 diferentes representações, requerendo a revisão, para atualização, da Resolução lançada em 2002.

A consulta questionava as razões de ainda ser considerado experimental procedimentos acessórios/secundários relacionados a redesignação de gênero do transexual feminino. O texto, cristalina o constrangimento diário dos transexuais que convivem com a presença das mamas, ou, que tenham que conviver com seu ciclo menstrual, mesmo pertencendo a outro gênero. (CFM, parecer 20, 2010) 
Frente a tal provocação, o conselheiro Edevard José de Araújo sugeriu: "que a resolução seja reavaliada, mantendo apenas a neofaloplastia como procedimento experimental" (CFM, parecer 20, 2010)

Assim, em 03 de setembro de 2010 foi publicada a Resolução CFM nº 1.955/2010, que suprimiu o texto legal o caráter experimental de procedimentos complementares sobre gônodas e caracteres sexuais secundários de todos os transexuais.

Feita a digressão, trazemos um quadro comparativo entre a primeira Resolução $\mathrm{n}^{\circ}$ 1.482/97 do CFM lançada e a atual Resolução $n^{\circ}$ 1.955/10 do CFM, evidenciando os avanços no texto:

\begin{tabular}{|c|c|}
\hline $\begin{array}{l}\text { Resolução no 1.482/97 do CFM } \\
\text { 1. Autorizar, a título experimental, a } \\
\text { realização de cirurgia de } \\
\text { transgenitalização tipo } \\
\text { neocolpovulvoplastia, neofaloplastia e } \\
\text { ou procedimentos complementares } \\
\text { sobre gônadas e caracteres sexuais } \\
\text { secundários como tratamento dos casos } \\
\text { de transexualismo; } \\
\text { 2. A definição de transexualismo } \\
\text { obedecerá, no mínimo, aos critérios } \\
\text { abaixo enumerados: } \\
\text { - desconforto com o sexo anatômico } \\
\text { natural; } \\
\text { - desejo expresso de eliminar os } \\
\text { genitais, perder as características } \\
\text { primárias e secundárias do próprio sexo } \\
\text { e ganhar as do sexo oposto; } \\
\text { - permanência desse distúrbio de forma } \\
\text { contínua e consistente por, no mínimo, } \\
\text { dois anos; } \\
\text { - ausência de outros transtornos } \\
\text { mentais. }\end{array}$ & $\begin{array}{l}\text { Resolução n' 1.955/10 do CFM } \\
\text { Art. } 1^{\text {o }} \text { Autorizar a cirurgia de transgenitalização } \\
\text { do tipo neocolpovulvoplastia e/ou procedimentos } \\
\text { complementares sobre gônadas e caracteres } \\
\text { sexuais secundários como tratamento dos casos } \\
\text { de transexualismo. } \\
\text { Art. } 2^{\circ} \text { Autorizar, ainda a título experimental, a } \\
\text { realização de cirurgia do tipo neofaloplastia. } \\
\text { Art. } 3^{\circ} \text { Que a definição de transexualismo } \\
\text { obedecerá, no mínimo, aos critérios abaixo } \\
\text { enumerados: } \\
\text { 1) Desconforto com o sexo anatômico natural; } \\
\text { 2) Desejo expresso de eliminar os genitais, perder } \\
\text { as características primárias e secundárias do } \\
\text { próprio sexo e ganhar as do sexo oposto; } \\
\text { 3) Permanência desses distúrbios de forma } \\
\text { contínua e consistente por, no mínimo, dois anos; } \\
\text { 4) Ausência de outros transtornos mentais. }\end{array}$ \\
\hline
\end{tabular}




\begin{tabular}{|c|c|}
\hline $\begin{array}{l}\text { 3. A seleção dos pacientes para cirurgia } \\
\text { de transgenitalismo obedecerá a } \\
\text { avaliação de equipe multidisciplinar } \\
\text { constituída por médico-psiquiatra, } \\
\text { cirurgião, psicólogo e assistente social, } \\
\text { obedecendo aos critérios abaixo } \\
\text { definidos, após dois anos de } \\
\text { acompanhamento conjunto: } \\
\text { diagnóstico médico } \\
\text { transexualismo; } \\
\text { - maior de } 21 \text { (vinte e um) anos; } \\
\text { - ausência de características físicas } \\
\text { inapropriadas para a cirurgia; } \\
\text { 4. As cirurgias só poderão ser } \\
\text { praticadas em hospitais universitários } \\
\text { ou hospitais públicos adequados à } \\
\text { pesquisa. } \\
\text { 196/96; Consentimento livre e esclarecido, de } \\
\text { acordo com a Resolução CNS no } \\
\text { data pua publicação. }\end{array}$ & $\begin{array}{l}\text { Art } 5^{\circ} \text { O tratamento do transgenitalismo deve } \\
\text { ser realizado apenas em estabelecimentos que } \\
\text { contemplem integralmente os pré-requisitos } \\
\text { estabelecidos nesta resolução, bem como a } \\
\text { equipe multidisciplinar estabelecida no artigo } \\
4^{0} . \\
\S 1^{\circ} \text { O corpo clínico destes hospitais, } \\
\text { devidamente registrado no Conselho Regional } \\
\text { de Medicina, deve ter em sua constituição os } \\
\text { profissionais previstos na equipe citada no } \\
\text { artigo } 4^{\circ} \text {, aos quais caberá o diagnóstico e a } \\
\text { indicação terapêutica. } \\
\S 2^{\circ} \text { As equipes devem ser previstas no } \\
\text { regimento interno dos hospitais, inclusive } \\
\text { contando com chefe, obedecendo aos critérios } \\
\text { regimentais para a ocupação do cargo. } \\
\S 3^{\circ} \text { Em qualquer ocasião, a falta de um dos } \\
\text { membros da equipe ensejará a paralisação de } \\
\text { permissão para a execução dos tratamentos. }\end{array}$ \\
\hline
\end{tabular}




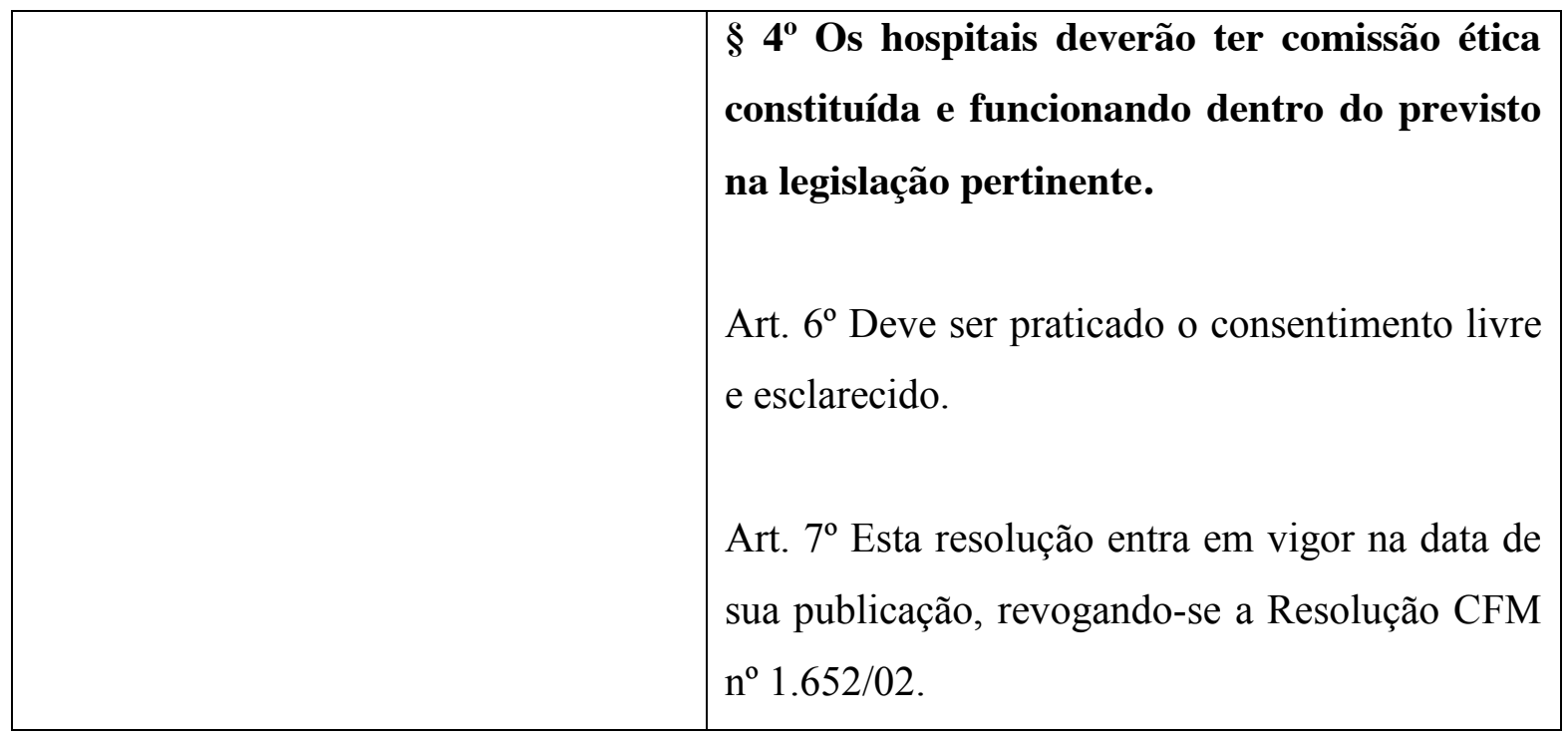

Importante destacar que a seleção dos pacientes para a cirurgia de transgenitalismo deve obedecer aos critérios traçados no artigo $4^{\circ}$ da Resolução CFM 1955/2010, carecendo de avalição de equipe multidisciplinar, após, no mínimo, dois anos de acompanhamento terapêutico e ausência de características físicas inapropriadas ao procedimento cirúrgico, sendo obrigatório o consentimento livre, sendo esclarecido sobre os procedimentos cirúrgicos. (VIEIRA, 2012, p. 177)

A indicação de tratamento, desrespeitando o artigo $4^{\circ}$ da Resolução do CFM 1955/2010, a quem não se revele efetivamente como um transexual, por erro de diagnóstico, é situação de suma gravidade. O erro de diagnóstico tem o condão de gerar o dever de indenizar caso venha a causar um dano para o paciente em decorrência a avaliação equivocada do profissional da área médica, que deveria reunir meios técnicos para indicar o tratamento adequado. (CUNHA, 2015, p. 252)

O item 2 do artigo $4^{\circ}$ da Resolução CFM 19.555/2010 também merece atenção, porque determina a idade mínima para passar pelo procedimento cirúrgico aos 21 (vinte e um) anos, não obstante, o Conselho Federal de Medicina não observou que a maioridade civil brasileira passou para os 18 (dezoito) anos. Assim, o indivíduo se torna capaz e apto a exercer seus direitos e deveres, podendo consentir livremente a partir dos 18 anos.

Depreende-se que, caso o paciente comece o tratamento aos 16 anos junto a equipe multidisciplinar, objetivando na terapêutica a sua melhora da saúde, cumprido os demais requisitos no artigo $4^{\mathrm{a}}$ da Resolução do CFM, este já poderia passar pelo procedimento cirúrgico aos 18 anos. Não seria prudente determinar que o indivíduo iniciasse o acompanhamento psicológico apenas aos 18 anos, para aos 21 anos poder passar pelo processo de redesignação do sexo. 
A Associação Nacional de Travestis e Transexuais (Antra), questionou ao CFM sobre a adequação do texto legal, para constar a correção da idade no texto da regra atual. A Presidente da Antra, Keila, defende que os transexuais devem ter acesso ao tratamento hormonal desde os 18 anos, essenciais para o contexto global do tratamento, essa medida reduziria o risco atual dos jovens, que recorrerem a clinicas clandestinas para ter acesso ao tratamento. Segundo Kely, a fila de espera tanto para cirurgia quanto para o tratamento com hormônios é longa. (Estadão, 2017)

A Assembleia Parlamentar do Conselho da Europa, via recomendação n. ${ }^{\circ}$ 1117, em 12 de setembro de 1989, coibiu a discriminação contra os transexuais, instituiu junto aos EstadosMembros que tomasse medidas de inclusão da identidade, tais como: inclusão de tratamento de mudança de sexo no Sistema Nacional de Saúde, deferimento de benefícios sociais aos desempregados ou aos que perderam sua habilitação, direito de alterar o nome no registro civil e o sexo na certidão de nascimento, adequando-os ao seu gênero real. (VIEIRA, 2012, p. 178)

Ao mesmo passo, o Estado, via Ministério da Saúde, publicou a Portaria 1.707/08 abarcando no Sistema Único de Saúde - SUS - instituiu o tratamento aos pacientes transexuais, permitindo a integralidade de atenção terapêutica e humanização dos usuários do SUS, respeitando a Resolução $n^{\circ}$. 1652/2002, que determina a necessidade de uma equipe multidisciplinar, composta por psicólogos e médicos, cirurgiões e psiquiatras, para indicação e aconselhamento de intervenção cirúrgica.

Não obstante, os progressos na esfera pública não pararam, em 19 de novembro de 2013, foi publicada a Portaria $n^{\circ} 2.803$ do Ministério da Saúde que redefiniu e ampliou o processo transexualizador no SUS, incluindo na lista de procedimentos médicos as cirurgias de transgenitalização e os procedimentos complementares.

A atualização normativa do Ministério da Saúde ocorreu diante da necessidade de cumprir a decisão proferida na Ação Civil Pública n $n^{\circ}$ 2001.71.00.026279-9/RS, que no dia 13 de setembro de 2013, determinou ao Ministério da Saúde o cumprimento integral, no prazo de 30 (trinta) dias, das medidas necessárias para possibilitar a realização no Sistema Único de Saúde (SUS) de todos os procedimentos médicos para garantir a cirurgia de transgenitalização e a readequação sexual no Processo Transexualizador, conforme os critérios estabelecidos na Resolução $n^{\circ} 1.652$ de 2002 do Conselho Federal de Medicina (CFM).

É possível vislumbrar que o ordenamento normativo segue avançando no tema, contudo, diante dos avanços já conquistados, pode-se assegurar que os transexuais detêm o direito à redesegnação de seu sexo, tanto na esfera particular, quanto na esfera pública, independente de autorização judicial. 


\section{Responsabilidade civil médico-hospitalar nos casos de cirurgias de redesignação do sexo}

No Brasil, a Carta Magna garante a integridade física e moral como um direito e garantia fundamental, previsto no inciso $\mathrm{X}$ do artigo $5^{\circ}$, especialmente à intimidade, vida priva, imagem, honra. O médico tem o dever de agir de forma a garantir ao paciente uma redução da angustia, buscando o bem-estar da pessoa. (ARAUJO, 2000, p. 112)

No mesmo sentido, o Código Civil brasileiro determina que todo aquele que cause danos a outrem, por ação ou omissão, ainda que meramente moral, ou ainda que age com abuso no exercício de um direito pratica ato ilícito (art. 186 e 187 do CC/02), devendo repará-lo, conforme artigo 927 do Código Civil, preceitos igualmente protegidos pelo artigo $5^{\circ}, \mathrm{V}$ e $\mathrm{X}$ da Constituição Federal. (CUNHA, 2015, p. 241)

No caso de indicação da cirurgia aos transexuais é preciso cautela, não se pode esquecer que antes da indicação deste procedimento é necessário o acompanhamento de equipe multidisciplinar por, no mínimo, dois anos.

O tratamento pertinente envolverá parecer de diversos profissionais, uma variada gama de intervenções, desde a psicológica à física, o que também inclui a utilização de hormônios e procedimento cirúrgico quando for o caso. Evidente que os profissionais que atuarem no tratamento se responsabilizam por todas as orientações e protocolos realizados. As intervenções de cunho psicológicos devem ser realizadas desde a mais tenra idade, sendo este passo inicial a garantia do bem-estar, desde de que seguramente constatado a condição de disforia de gênero da criança, nos termos do código 302 do Manual Diagnóstico e Estatístico de Transtornos Metais (DSM-IV). (CUNHA, 2015, p. 684)

A responsabilidade civil dos médicos empregados de hospitais, públicos ou privados, é estipulada pela Código de Defesa do Consumidor, ou seja, sempre será objetiva ao hospital, com fundamento no art. 14, caput do CDC. Entretanto, poderá o hospital se valer de ação regressiva em face do médico nos termos do parágrafo único do art. 13 do CDC. (LOPEZ, 1999, p. 85)

Maria Helena Diniz pontua que no seu entendimento a operação para adequação do sexo físico ao psicológico apresenta-se como uma obrigação de meio e não de resultado, vez que o médico não tem como garantir a cura mental do paciente, a perfeição absoluta ou mesmo a obtenção de orgasmo, o que seria diferente da situação em que o profissional se compromete a garantia de que o sujeito após a operação continue a ter condições de continuar a realizar as 
suas necessidades fisiológicas, como também o será de resultado a intervenção que tenha cunho meramente estético, ensejando responsabilidade civil objetiva. (DINIZ, 2011, p. 327)

As obrigações de meio são aquelas em que a própria prestação do serviço exige apenas que se utilize o meio adequado, sem olhar o resultado. Como nos contratos médicos, que se obrigam a empregar a melhor técnica para alcançar o melhor resultado ao paciente. A obrigação de resultado, o contratante se obriga a alcançar determinado fim especifico, sob pena de responder pelo não cumprimento da obrigação. (LOPEZ, 1999, p. 53-54)

O médico, para assegurar seus riscos, deverá informar ao paciente sobre todo o processo cirúrgico e tratamento, antes, durante e depois, garantindo que todos os procedimentos não tenham consequências ou sequelas. Desta feita, o médico deverá demonstrar os pormenores das vantagens e desvantagens das técnicas que serão utilizadas. (LOPEZ, 1999, p. 87)

Tereza Ancona Lopez conceitua que, caso haja lesão a integridade física da pessoa, parte do direito da personalidade, será configurado o dano estético:

\begin{abstract}
Quanto ao dano estético, é a lesão à integridade física de alguém (direito da personalidade) e, portanto, bem fora do comercio, não vai ser admitida nenhuma convenção visando a sua não ressarcibilidade, tanto em seus aspectos morais quanto matérias (pois aqui não se admite o princípio do "violenti non fit injuri"). Em outras palavras, o prejuízo estético deve ser sempre indenizado, mesmo que tenha se originado no contrato, pois sua proteção extrapola o próprio acordo de vontades. (LOPEZ, 1999, p. 58)
\end{abstract}

Quanto aos procedimentos que se derem pelo Sistema Unico de Saúde (SUS), pode-se sustentar a responsabilidade objetiva do Estado, fundada no art. 37 , inc. XXI, $\S 6^{\circ}$ da $\mathrm{CF} / 88$. Nas instituições privadas, caberá a aplicação do Código de Defesa do Consumidor, cabendo objetivamente o dever de indenizar, conforme disposto no art. 14, caput do CDC (responsabilidade pelo fato do serviço do hospital particular) e $\S 4^{\circ}$ art. 14 do CDC (responsabilidade pelo fato do serviço dos profissionais liberais, no caso os médicos).

\title{
6. Conclusão
}

O direito ao tratamento de disforia de gênero, após longos anos de debates e avanços normativos, é garantido ao transexual, haja vista o reconhecimento da personalidade da pessoa humana, ultrapassado o modelo binário masculino e feminino para reconhecer a identidade de gênero, sexo e sexualidade como direitos diversos entre si, mas complementares.

Entretanto, ainda é de responsabilidade do médico a identificação primária do sexo biológico nas crianças recém nascidas, cabendo ao profissional utilizar todas as técnicas disponíveis para indicar o sexo que constará na certidão de nascimento. 
Tal indicação não se confunde e não deve prejudiciar a identidade de gênero, esta somente poderá ser diagnosticada após o nascimento, no desenvolver do intelecto da pessoa, pois está ligada à experiência interna e individual de cada ser humano. O gênero da pessoa pode ou não corresponder ao sexo atribuído no nascimento. Em sendo correspondente a pessoa será denominada de cisgenera; caso contrário, a pessoa será identificada como transgenera.

Nos casos de diagnóstico de transgenia, o direito à intimidade deve ser resguardado tendo em vista o alcance da dignidade da pessoa humana. Assim, o transgenero poderá, em seu livre convencimento, permanecer na ambiguidade de gênero. A opção de gênero, conflitiva ou não, é direito próprio da pessoa.

A Declaração Universal dos Direitos do Homem de 1948 e o art. $1^{\circ}$, inc. III, da CF/88, ressalvam o homem como ponto de referência do sistema normativo. Nesse sentido, a bioética tem o condão de balizar as práticas e os protocolos de tratamento em seres humanos.

O tratamento da disforia de gênero é permitido no Brasil desde 1997, atualmente do protocolo da equipe multidisciplinar estão previstas na Resolução $\mathrm{n}^{\circ}$ 1.955/2010 do Conselho Federal de Medicina (CRM).

Entretanto, por se tratar de resolução de um Conselho Federal, está não tem força normativa, servido apenas de base aos efeitos jurídicos dos procedimentos médicos. A lacuna normativa contribui para a invisibilidade e exclusão dos transexuais.

Importante destacar desta resolução que o art. $4^{\circ}$ estipula que os transexuais devam ser acompanhados por equipe multidisciplinar, por no mínimo dois anos, incluindo acompanhamento terapêutico, endócrino, psiquiátrico, cirurgião e assiste social, destacando-se, ainda, para qualquer protocolo medico, seja de aplicação de hormônios ou cirúrgico, o dever de informação medica, que deve ser registrado e obtido o livre consentimento esclarecido ao paciente.

As garantias de acesso ao tratamento dos transexuais são asseguradas tanto no âmbito público como no privado, o Estado, via Ministério da Saúde, publicou a Portaria 2803/2013 abarcando os procedimentos no Sistema Único de Saúde - SUS para os transexuais e travestis, independente de autorização judicial, inclusive, alargaram-se os direitos do paciente, posto que o tratamento ganhou o status de sigilo medico paciente.

Possíveis danos causados aos transexuais, por erro médico, no processo de tratamento, esteja o tratamento em qual fase for, é ressalvado o direito à indenização pelo Código Civil e pela Constituição Federal, nos artigos 186 e 187 c.c. 927 do CC/02 e artigo 5o inc. V e inc. X da $\mathrm{CF} / 88$. 
Quanto aos médicos empregados em hospitais públicos ou privados, a responsabilidade civil é estipulada pelo Código de Defesa do Consumidor. Nesse sentido, equivale dizer que o Hospital será objetivamente o responsável, com fundamento no art. 14, caput do CDC, podendo valer-se de ação regressiva aos profissionais.

Já a responsabilidade civil pelo procedimento cirúrgico, em si, é dividida em procedimentos. É de meio a obrigação pelo bom funcionamento fisiológico do sexo do paciente; entretanto, é de fim o resultado estético esperado, ensejando responsabilidade civil objetiva.

Os procedimentos médicos que ocorrem no Sistema Único de Saúde (SUS) seguem o entendimento de que a responsabilidade do Estado é objetiva, para qualquer procedimento, fundada no art. 37, inc. XXI, $\S 6^{\circ}$ da $\mathrm{CF} / 88$. Enquanto nas instituições privadas, será aplicado o Código de Defesa do Consumidor, sendo objetiva a responsabilidade de indenizar os danos, conforme disposto no art. 14, caput do Código de Defesa do Consumidor.

Deste prisma, nota-se que ambas as responsabilidades são decorrentes de lei, o que acarreta a extinção da responsabilidade contratual, mesmo nos casos em que há o contrato, a relação de hipossuficiência da vítima seguirá a responsabilidade legal.

\section{Referências bibliográficas}

ALVES, Jaiza Sammara de Araújo. LIMA, Vitória Raissa Jacó de. Alteração do nome dos transexuais e a problemática da autorização da cirurgia de transgenitalização no Brasil. In: Revista Eletrônica de Direito do Centro Universitário Newton Paiva. Belo Horizonte, n. 30, set/dez 2016, p.113-124.

ARAUJO, Luiz Alberto David. A proteção constitucional do transexual. São Paulo: Saraiva. 2000 .

BARBOZA, Heloisa Helena. Disposição do próprio corpo em face da bioética: o caso dos transexuais. In: Gozzo, Debora; Ligiera, Wilson Ricardo. Bioética e direitos fundamentais. São Paulo: Saraiva, 2012, p. 126-147.

. Responsabilidade civil em face das pesquisas em seres humanos: efeitos do consentimento livre e esclarecido. In: MARTINS-COSTA, Judith; MOLLER, Letícia Ludwig. Bioética e responsabilidade. Rio de Janeiro: Forense, 2009 p. 205-234. 
BRASIL. Declaração Universal dos Direitos Humanos. Disponível em: http://unesdoc.unesco.org/images/0013/001394/139423por.pdf Acesso em: 05 de novembro de 2017.

CAPELO DE SOUSA, Rabindranath V. A. O Direito Geral de Personalidade, Coimbra: Coimbra Editora, 1995.

CUPIS, Adriano de. I diritti dela personalità. Milão: Giuffré, 1950.

CERQUEIRA, E. K., VERRESCHI, I.T.D.N. Apud SOUZA, Mariana Barbosa de. VIEIRA, Otavio j. Zini. Transexualidade - a quebra de paradigmas à luz do Biodireito. In: Revevista da Faculdade de Direito UFMG, Belo Horizonte. n. 68, jan/jun 2016, p. 587-608.

CUNHA, Leandro Reinaldo da. Identidade e redesignação de gênero: aspectos da personalidade, da família e da responsabilidade civil. Rio de Janeiro: Ed. Lumes Juris, 2015

DIAS, Maria Berenice. Homoafetividade e os direitos LGBTI. 6 Ed. São Paulo: Revista dos Tribunais, 2014.

DINIZ, Maria Helena. O estado atual do biodireito. 8 ed. São Paulo: Saraiva, 2011.

ESTADÃO. CFM discute redução da idade mínima para cirurgia de mudança de sexo. Materia de Lígia Formenti. Disponivel em: http://saude.estadao.com.br/noticias/geral,cfm-discutereducao-da-idade-minima-para-cirurgia-de-mudanca-de-sexo,70001886131 Acesso em: 05 de novembro de 2017.

GOGLIANO, Daisy. Direitos Privados da Personalidade. Dissertação de Mestrado. São Paulo: Faculdade de Direito da Universidade de São Paulo. 431 p., 1982.

GONÇALVES, Camila de Jesus Mello. A transexualidade sob a ótica dos direitos humanos: uma perspectiva de inclusão. Tese de Doutorado. São Paulo: Faculdade de Direito da Universidade de São Paulo. 269 p., 2012. Disponível em: http://www.teses.usp.br/teses/disponiveis/2/2140/tde-04032013-105438/pt-br.php Acesso em: 27 de novembro de 2017. 
LAFER, Celso. Filosofia do direito e princípios gerais. In: ALVES, Alaôr Caffé; LAFER, Celso; GRAU, Eros Roberto; COMPARATO, Fábio Konder; TELLES JUNIOR, Goffredo da Silva; FERRAZ JUNIOR, Tércio Sampaio. O que é Filosofia do Direito? Barueri-SP: Manole, 2004, p. 51-73.

LIMONGI FRANÇA, Rubens. Manual de direito civil direito objetivo, direitos subjetivos, direitos privados da personalidade. 2 ed. São Paulo: Revista dos Tribunais, 1971.

LOPEZ, Teresa Ancona. O dano estético: responsabilidade civil. 2 ed. São Paulo: Revista dos Tribunais, 1999.

MATOS, Eneas de Oliveira. Dano moral e dano estético. Rio de Janeiro: Renovar, 2008.

MARTINS-COSTA, Judith; MÖLLER Letícia Ludwig (org.). Bioética e Responsabilidade. Rio de Janeiro: GEN e Companhia Editora Forense, 2009.

MELLO, Maricilda Palandi de. ASSUMPÇÃO, Juliana de G. HACKEL, Christine. Genes Envolvidos na Determinação e Diferenciação do Sexo. In: Arquivos Brasileiros de Endocrinologia \& Metabologia. v. 49, n. 1. fev. 2015. p. 14-25.

MELO, Marco Aurélio Bezerra e AZEVEDO, Fábio de Oliveira. Notas sobre competência nas ações de alteração de identidade de gênero por transexualidade. In: Revista da EMERJ. Rio de Janeiro, v. 19. n. 73. abr/jun 2016, p. 218-224.

MENEZES CORDEIRO, António. Tratado de Direito Civil Português. Vol. I - Parte Geral, Tomo I: Introdução, doutrina geral e negócio jurídico. 3. ed. $2^{\mathrm{a}}$ reimp. Coimbra: Almedina, 2009.

PERLINGIERI, Pietro. Il Diritto Civile nella legalità Costituzionale: secondo il sistema italocomunitario dele fonti. 3. ed. Tomo II: Interpretazione sistemática e assiologica, situazioni soggettive e rapporto giuridico. Napoli: Edizioni Scientifiche Italiane, 2006.

QUAGLIA, Dorina. O paciente e a intersexualidade. São Paulo: Sarvier, 1980. 
ROBERT, Jacques. Droits de l'homme et libertés fondamentales. 8 ed. Paris: Montchrestien, 2009 .

SALAMACHA, Consuelo Taques Ferreira. Erro médico: inversão do ônus da prova. 3 ed. São Paulo: Juruá, 2013.

SCHREIBER, Anderson. Direitos da Personalidade. 2 ed. São Paulo: Atlas, 2013.

SOUZA, Mariana Barbosa de; VIEIRA, Otavio J. Zini. Transexualidade - a quebra de paradigmas à luz do biodireito. In: Revista da Faculdade de Direito UFMG. Belo Horizonte, n. 68 . jan/jun 2016, p. 587-608.

YOGYAKARTA, Princípios. A aplicação da legislação internacional de direitos humanos em relação à orientação sexual e identidade de gênero. Disponível em: http://www.yogyakartaprinciples.org/. Acesso em 26 de novembro de 2017.

VIEIRA, Tereza Rodrigues. Nome e sexo: mudanças no registro civil. 2 ed. São Paulo: Atlas, 2012. 
E

Este livro reúne artigos científicos apresentados e debatidos nos Grupos de Trabalho: "DIREITO CIVIL, DE FAMÍLIA E CONSTITUICIONAL" e "GÊNERO, SEXUALIDADES E DIREITO" no decorrer do VIII Encontro Internacional do CONPEDI (Conselho Nacional de Pesquisa e Pós-Graduação em Direito - Brasil), realizado entre os dias 06 e 08 de setembro de 2018 na cidade de Zaragoza - Espanha. 